\title{
COLHËITA MECANIZADA: DESEMPENHO OPERACIONAL E ECONÔMICO EM CANA SEM QUEIMA PRÉVIA
}

\author{
SERGIO MORAIS CARVALHO FILHO \\ Engenheiro Mecânico
}

Orientador: Prof. Dr. Tomaz Caetano Cannavam Ripoli

\begin{abstract}
Dissertação apresentada à Escola
Superior de Agricultura "Luiz de Queiroz", Universidade de São Paulo, para obtenção do título de Mestre em Agronomia. Área de Concentração: Máquinas Agrícolas.
\end{abstract}

PIRACICABA

Estado de São Paulo - Brasil

Julho -2000 


\title{
Dados Internacionais de Catalogação na Publicação (CIP) \\ DIVISĀO DE BIBLIOTECA E DOCUMENTAÇĀO - Campus "Luiz de Queiroz"/USP
}

\author{
Carvalho Fitho, Sergio Morais \\ Colheita mecanizada: desempenho operacional e econômico em cana sem queima \\ prévia / Sergio Morais Carvalho Filho. - - Piracicaba, 2000. \\ 108 p. : il. \\ Dissertação (mestrado) - Escola Superior de Agricultura Luiz de Queiroz, 2000. \\ Bibliografia. \\ 1. Cana-de-açúcar 2. Colhedora 3. Colheita mecânica 4. Custo operacional 5. \\ Máquina agricola I. Titulo \\ CDD 633.61
}

"Permitida a cópia total ou parcial deste documento, desde que citada a fonte -0 autor" 


\section{DEDIDO}

Aos meus pais, Olga Del'Vigna e Sergio Carvalho, pelo esforço, almejando um futuro brilhante a seus filhos.

À minha esposa Sandra Youssef,

À minha filha Soraya Youssef Carvalho, À meu filho André Youssef Carvalho, OFERECO. 


\section{AGRADECIMENTOS}

A Deus, por entender que: "Ainda quando eu tivesse a linguagem dos anjos; quando eu tivesse o dom de profecia, e conhecesse todos os mistérios e toda ciência; quando eu tivesse toda a fé possível, até transportar as montanhas, se não tivesse caridade, eu nada seria". (Apóstolo Paulo, 1․ Epistola aos Corintios, Cap.XIII, v. de 1 a 2.)

Ao Prof. Dr. Tomaz Caetano Ripoli, pela verdadeira amizade, incentivo e orientação na realização deste trabalho.

Aos Profs. Dr. Luiz Geraldo Mialhe, Dr. Luiz Antonio Balastreire, Dr. Roberto Bovi e ao amigo Edimilson Ruiz pelas sugestões oferecidas.

Aos amigos Fernando Pascholatti, Heitor Mazzoti, Danilo Marrara, Moizéis Nery e Wagner Campaner, pela amizade e por tornar o ambiente de trabalho mais agradável.

Ao Engenheiro Francisco Cabeça da Usina Dabarra S/A, pela colaboração no fornecimento de importantes informações de campo.

A Diretoria da Usina Dabarra, que permitiu e forneceu toda infraestrutura necessária para realização deste estudo.

A todas as pessoas que direta ou indiretamente contribuíram para a realização deste trabalho, agradeço. 


\section{SUMÁRIO}

Páginas

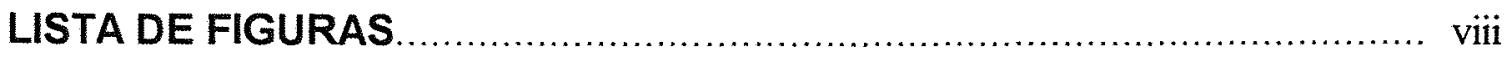

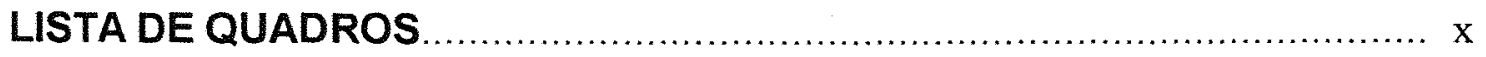

LISTA DE ABREVIATURAS E SIMBOLOS ....................................... xi

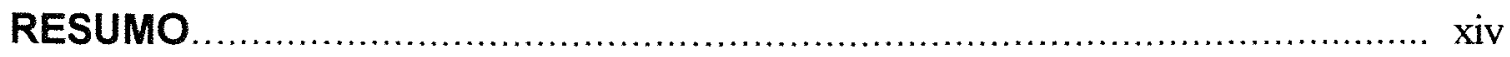

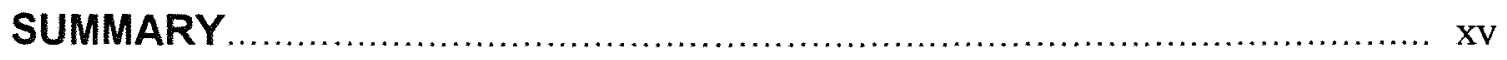

1 INTRODUÇÃO

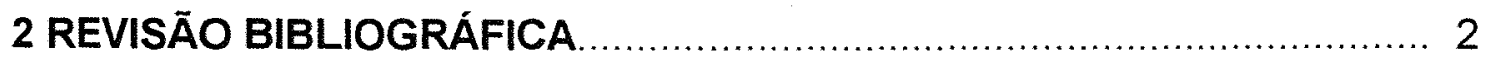

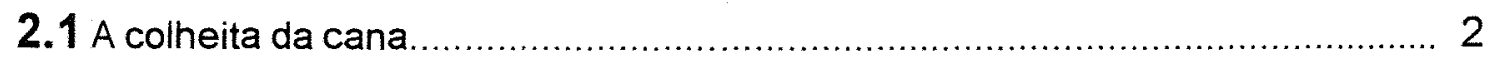

2.2 Histórico da mecanização da colheita da cana.............................................. 3

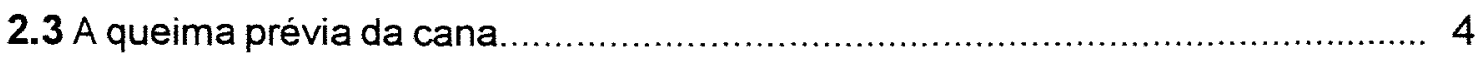

2.4 Aspectos legais, ambientais e ocupacionais............................................. 6

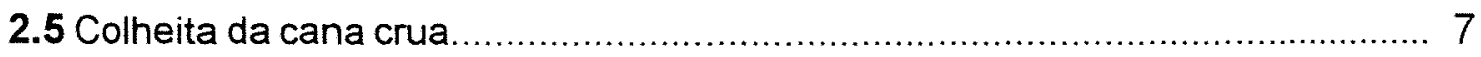

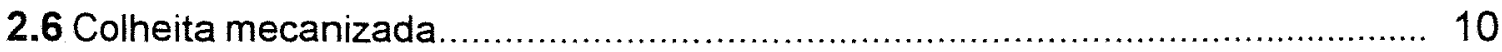

2.7 Fatores envolvidos na seleção e na Capacidade Operacional das colhedoras.. 13

2.8 A sistematização da lavoura como pré-requisito à colheita mecanizada........... 18

2.9 Comparativo de custos e desempenhos : colheita mecanizada X manual........ 20

2.10 Perdas e matéria-estranha.................................................................... 21

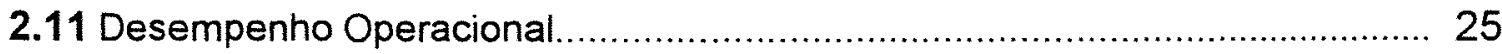

2.12 Desempenho Econômico ........................................................................... 30

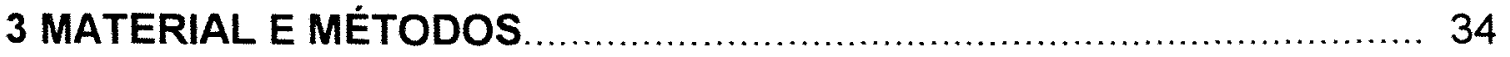

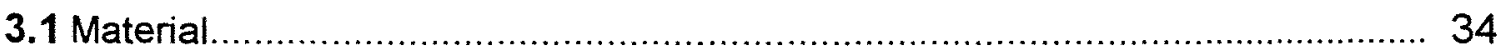

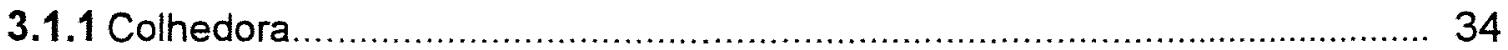


3.1.2 Caracterização das condições de campo .................................................. 38

3.1.3 Caracterização dos veículos de transporte................................................ 38

3.1.4 Equipamentos para determinações de campo .......................................... 39

3.1.5 Equipamento para determinação do consumo de combustível.................... 39

3.1.6 Laboratório para análises tecnológicas..................................................... 40

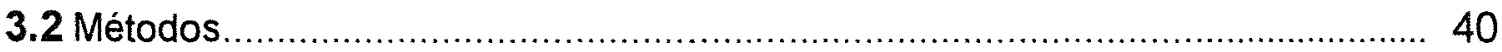

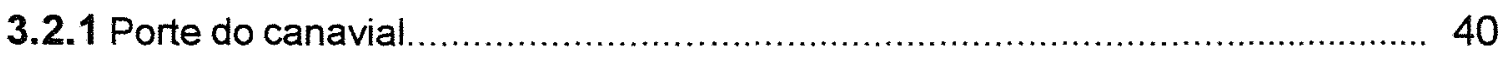

3.2.2 Densidade média dos colmos e matéria estranha vegetal.......................... 41

3.2.3 Comprimento médio dos colmos......................................................... 41

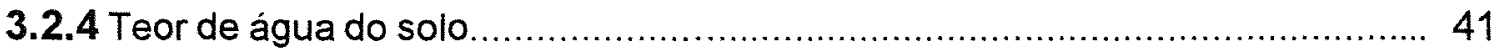

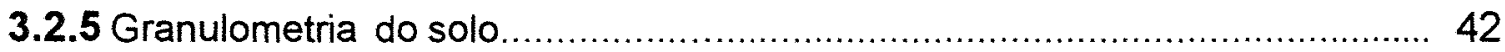

3.2.6 Idade e grau de maturação da cultura.................................................... 42

3.2.7 Desempenho Operacional da colhedora ............................................... 42

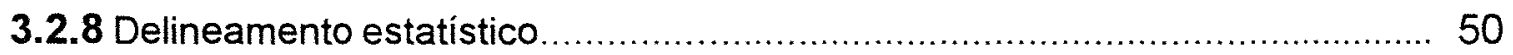

3.2.9 Desempenho Econômico da colhedora .................................................... 50

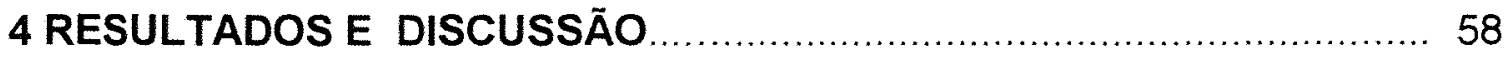

4.1 Caracterização das condições do canavial................................................... 58

4.2 Desempenho Operacional da colhedora..................................................... 61

4.3 Perdas e Qualidade da matéria-prima colhida............................................69 69

4.4 Desempenho Econômico da colhedora........................................................ 89

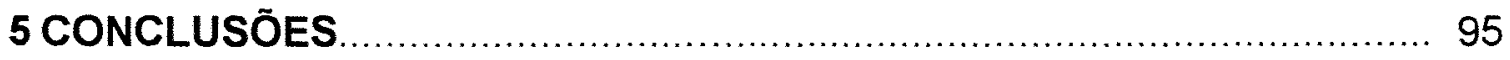

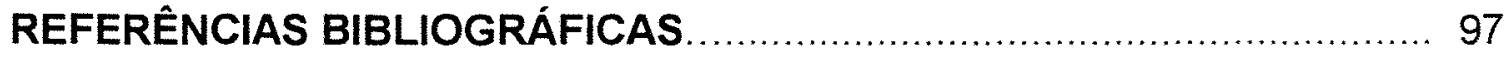
ANEXOS 


\section{LISTA DE FIGURAS}

Figuras

Páginas

1 Triângulo padrão, para determinação do porte do canavial.............................. 16

2 Desenho esquemático do espécime estudado................................................. 36

3 Bancada para calibração do medidor de combustivel.................................... 40

4 Desenho esquemático das áreas de coleta, para determinação do porte, produtividade agrícola dos colmos e caracterização da biomassa.

5 Vista da área de coleta de perdas no campo, resultante das diversas operações efetuadas.

Medidor de combustivel instalado na colhedora

7 Resultado da caracterização percentual do porte do canavial

8 Caracterização das produtividades da biomassa, antes da ação da colhedora.

9 Resultados de produtividades agrícolas, com base no material colhido, nas velocidades estudadas.

10 Resultados obtidos de qualidade da matéria-prima.

11 Resultados obtidos das médias das velocidades de deslocamento da colhedora, durante os ensaios

12 Resultados obtidos das médias da capacidade efetiva bruta para as velocidades utilizadas nos ensaios.

13 Correlação linear da capacidade efetiva bruta.

14 Resultados obtidos da Eficácia de Manipulação da colhedora para as velocidades estudadas.

15 Resultados obtidos das médias das capacidades efetivas liquidas para as velocidades estudadas.

16 Resultados das capacidades operacionais em função das eficiências de campo estimadas de $45,55,65,75 \%$, nas velocidades estudadas

17 Resultados do consumo de combustivel em $1 . \mathrm{h}^{-1}$, para as velocidades estudadas.

18 Resultados do consumo de combustivel em $1 . \mathrm{t}^{-1}$, para as velocidades estudadas.

19 Resultados de colmos e suas frações deixadas no campo nas velocidades estudadas.

20 Percentagem de rebolos inteiros deixados no campo nas velocidades estudadas

21 Percentagem de frações de rebolos deixados no campo nas velocidades estudadas

22 Percentagem de rebolos na soqueira, nas velocidades estudadas.

23 Percentagem de perdas totais deixadas no campo nas velocidades estudadas.

24 Resultados médios dos índices de ponteiros contidos na matéria-prima, no veiculo de transporte para as 4 velocidades estudadas.

25 Resultados médios dos índices de folhas verdes contidas na matéria-prima, no veículo de transporte para as 4 velocidades estudadas

26 Resultados médios dos indices de palhas contidas na matéria-prima, no veículo de transporte para as 4 velocidades estudadas 
27 Resultados médios dos índices de raizes contidas na matéria-prima, no veículo de transporte para as 4 velocidades estudadas

28 Percentagem de raizes arrancadas nas velocidades estudadas.

29 Resultados médios dos índices de matéria estranha vegetal contida na matéria-prima, no veículo de transporte nas 4 velocidades estudadas.

30 Resultados médios dos índices de matéria estranha mineral contida na matéria-prima, no veículo de transporte nas 4 velocidades estudadas.

31 Resultados médios dos indices de matéria estranha total contida na matériaprima, no veículo de transporte nas 4 velocidades estudadas.

32 Resultados médios dos parâmetros da qualidade tecnológica da matéria prima, $\%$ do caldo, nas 4 velocidades ensaiadas.

33 Resultados médios dos parâmetros da qualidade tecnológica da matéria prima, $\%$ da cana, nas 4 velocidades ensaiadas.

34 Freqüencia de comprimento dos rebolos na velocidade de ensaio $V 1$

35 Freqüência de comprimento dos rebolos na velocidade de ensaio V2 85

36 Freqüência de comprimento dos rebolos na velocidade de ensaio $V 3$. 85

37 Freqüência de comprimento dos rebolos na velocidade de ensaio V4 86

38 Percentual do Cisalhamento dos rebolos na velocidade de ensaio $V 1$ 86

39 Percentual do Cisalhamento dos rebolos na velocidade de ensaio V2. 87

40 Percentual do Cisalhamento dos rebolos na velocidade de ensaio V3. 88

41 Percentual do Cisalhamento dos rebolos na velocidade de ensaio V4 88

42 Representação dos custos da colhedora, para as 16 capacidades operacionais.

43 Regressäo obtida para custos da colhedora, nas 16 capacidades operacionais.

44 Itens de dispêndios em \%, da colhedora na v2 e eficiência de campo de 45 $\%$.......

45 Estimativas de custos de peças de reposição \& serviços mecânicos da colhedora, em 7 anos 


\section{LISTA DE QUADROS}

Quadros

Páginas

1 Valores médios de Desempenho Operacional em 29 Usinas produtoras de açúcar e álcool, referentes às safras 96/97 e 97/98.

2 Parâmetros de Desempenho de colhedoras de cana-de-açúcar. 26

3 Parâmetros de Desempenho de colhedora CC 2000, na Usina Guarani....... 27

4 Resultados médios de Capacidade Efetiva - CE (t. $\left.h^{-1}\right)$, de Índices de Matéria Estranha Vegetal - IV (\%), Mineral - IM (\%), Não Identificada - II (\%), Total - IT (\%), e Perdas de matéria-prima (t.ha ${ }^{-1}$ ou \%) para cortadoras e colhedoras de cana-de-açúcar.

5 Resultados de Desempenho Operacional em dois ensaios com CC-2000, realizados em cana crua.

6 Desempenho Operacional das Colhedoras, Gladiator e CC2000. 29

7 Custo de colheita para a colhedora, nas 16 Capacidades Operacionais adotadas, considerando 18.900 horas em 6 anos de vida útil. 


\section{LISTA DE ABREVIATURAS E SIMBOLOS}

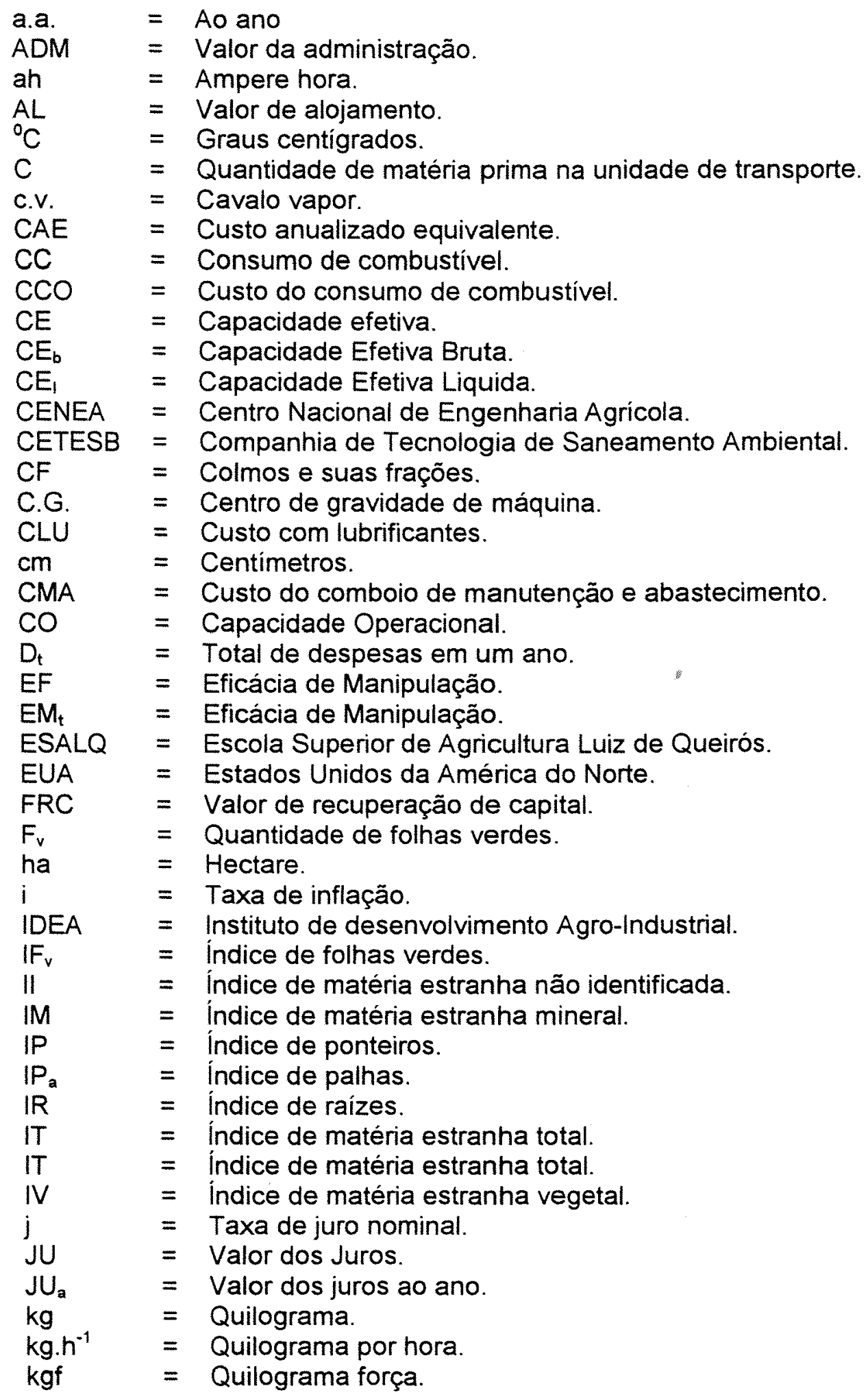




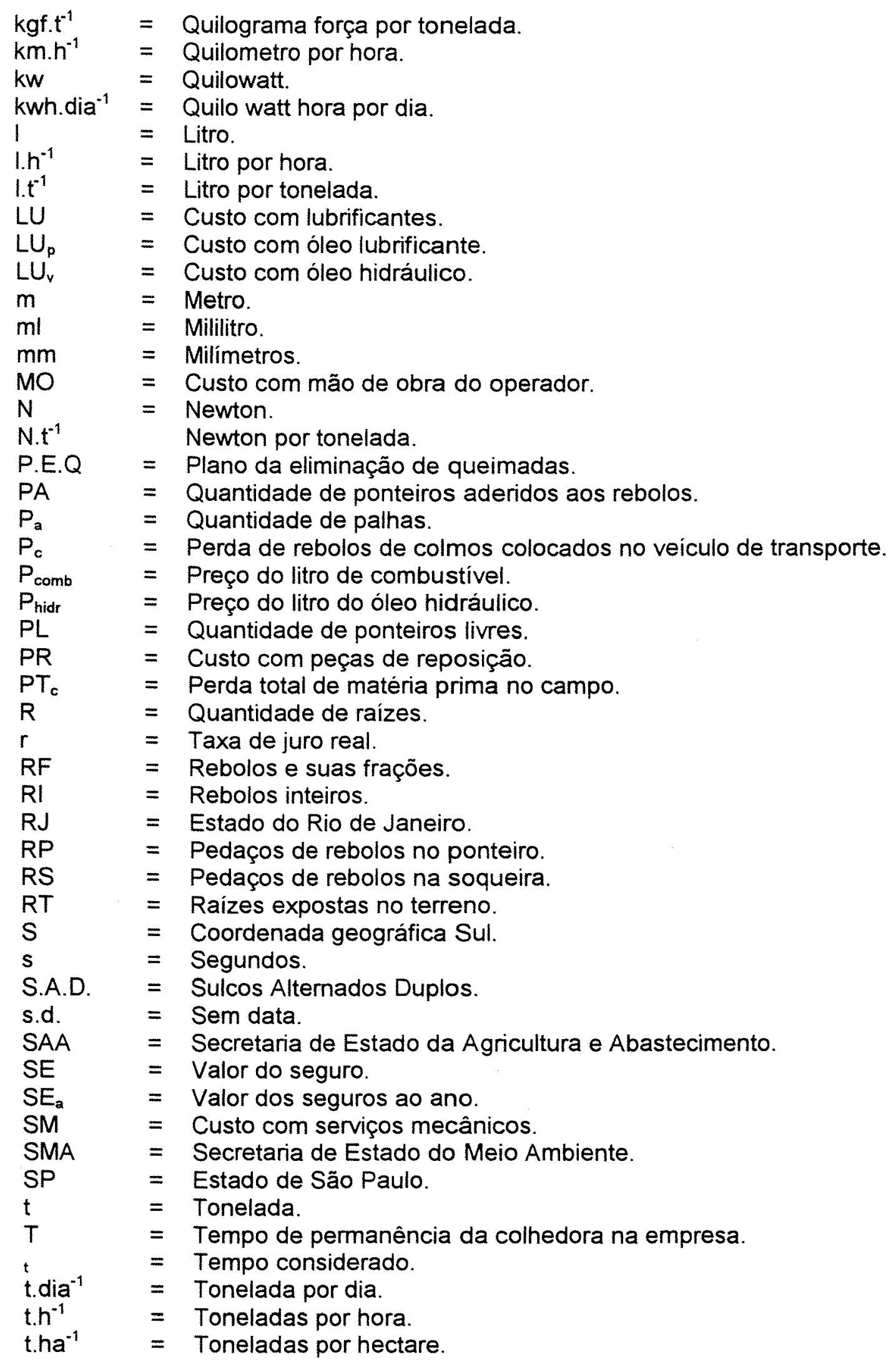




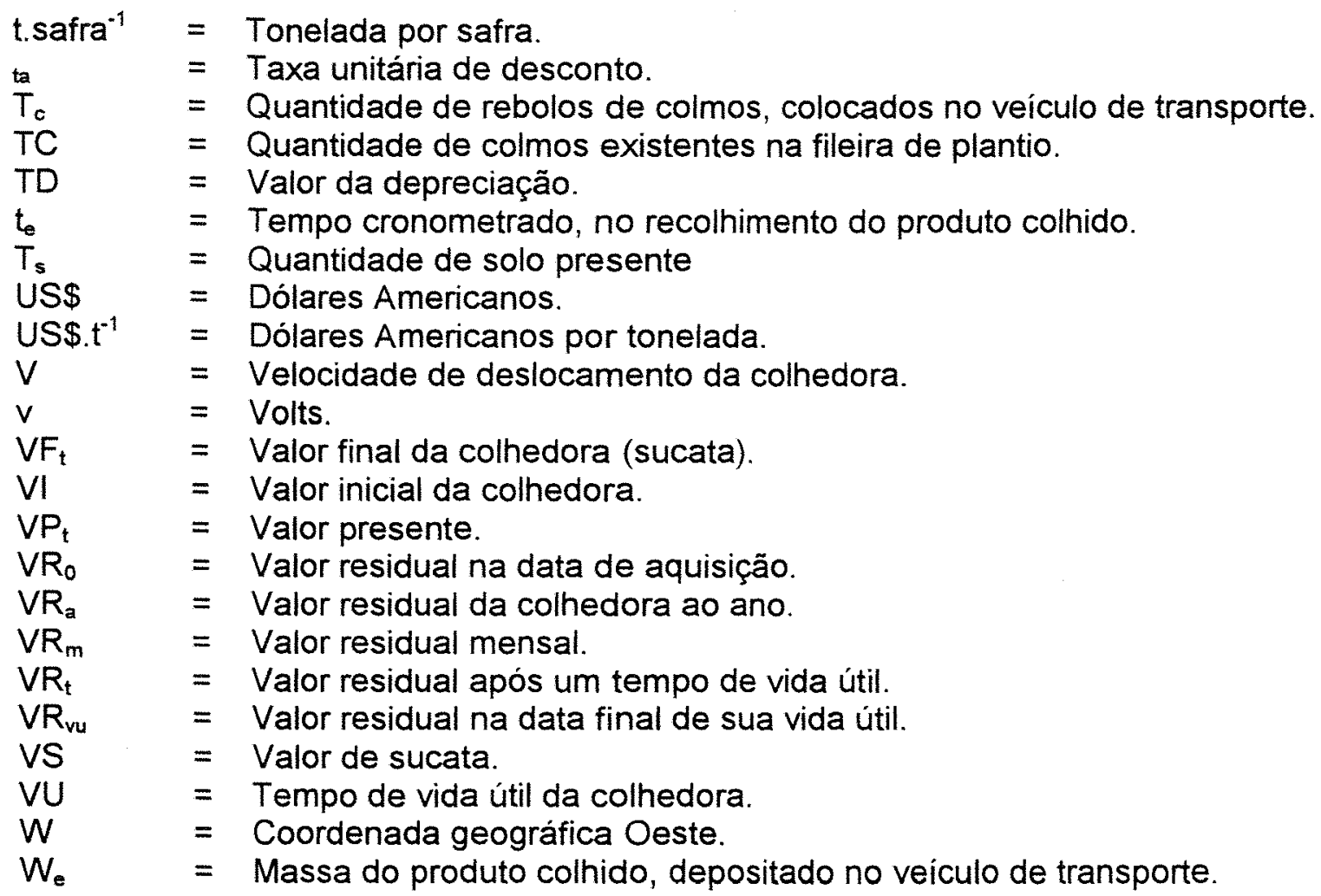




\section{COLHEITA MECANIZADA: DESEMPENHO OPERACIONAL E ECONÔMICO EM CANA SEM QUEIMA PRÉVIA}

\section{RESUMO}

- Brasil é, atualmente, o maior produtor mundial da cana-de-açúcar (Saccharum spp), produzindo 338 milhões de toneladas na safra 97/98, o que representa $27 \%$ da produção mundial, IDEA (1998). A colheita mecanizada é de extrema importância como mostra Ripoli e Paranhos (1987) por dois aspectos fundamentais; o primeiro devido a crescente dificuldade e encarecimento de mão-deobra para o corte manual, e o segundo ao interesse na obtenção de aumentos nos desempenhos das operações de colheita, com sua conseqüente diminuição de custo.

Atualmente fatores legais como o Decreto Federal no 2.661 de 08 de julho de 1998 e Decreto do Estado de São Paulo no 42.056 de 06 de agosto de 1997, abordando a proibição gradual da queima da cana-de-açúcar, tende a incrementar a mecanização da colheita desta cultura.

A hipótese deste trabalho é que a variável velocidade de deslocamento, reflete nos desempenhos operacionais e econômicos, de colhedoras, sob mesmas condições de campo. Este trabalho avaliou o desempenho operacional e econômico de uma colhedora em canavial sem queima prévia.

As determinações de campo foram realizadas em área da Usina Dabarra S/A, no município de Barra Bonita - SP, entre os dias 7 e 17 de julho de 1998, utilizando-se a variedade $\mathrm{RB} 835089$ em soqueira de $3^{\circ}$ corte, sem queima de pré-colheita.

Pelos resultados obtidos, concluiu-se que a variável velocidade de deslocamento, tem influência no desempenho operacional e econômico, assim como a eficiência do sistema de colheita. A velocidade de colheita, de $5,39 \mathrm{~km} \cdot \mathrm{h}^{-1}$ apresentou o melhor desempenho econômico, menores perdas no campo e menor índice de matéria estranha. Os cenários obtidos mostraram os custos de colheita variando de 0,66 a 3,82 US\$. $\mathrm{t}^{-1}$ de cana colhida. 


\section{AUTOMATED CROP: I CARRY OUT OPERATIONAL AND ECONOMICAL IN CANE WITHOUT IT BURNS PREVIOUS}

\section{SUMMARY}

Brazil is, now, the largest world producer of the sugar-cane (Saccharum spp), producing 338 million tons for crop $97 / 98$, that represents $27 \%$ of the world production, IDEA (1998). The automated crop is extremely important as the display Ripoli and Paranhos (1987) shows for it goes two fundamental aspects; the first for growing difficulty and labor raising for the manual cut, and the second for the interest in obtaining of increases in the acting's of the crop operations, with its consequent cost decrease.

Now legal factors as the Federal Ordinance in the 2.661 of July 08,1998 and Ordain of the State of São Paulo no 42.056 on August 06, 1997, approaching the gradual prohibition of burning the sugar-cane, it tends to increase the mechanization of the crop of this culture.

The hypothesis of this work is that the variable displacement speed, contemplates in the operational and economical actings, of gatherer, under same field conditions. This work evaluated the operational and economical acting of a gatherer in sugar cane plantation without previous burning.

The field determinations were accomplished in area of the Usina Dabarra S/A, in the municipal district of Barra Bonita-SP, between the 7 and July 17, 1998, being used the variety RB835089 in knuckle-duster of 30 cut, without of pré-crop burning.

For the obtained results, it was ended that the variable displacement speed, has influence in the operational and economical acting, as well as the efficiency of the crop system. The crop speed, of $5,39 \mathrm{~km} \cdot \mathrm{h}^{-1}$ presented the best acting economical, smaller losses in the field and smaller matter index finds strange. The obtained sceneries showed the crop costs varying from 0,66 to 3,82 US\$. $t^{-1}$ of picked cane. 


\section{INTRODUÇÃO}

A lavoura canavieira no Brasil tem se expandido significativamente, atingindo mais de 338 milhões de toneladas na safra 1997/1998. O Brasil é o maior produtor com $27 \%$ da produção mundial e, dentre as culturas brasileiras, pelos produtos e subprodutos que gera, é uma das mais importantes, IDEA (1998).

Com a cana-de-açúcar obtem-se a produção de açúcar, álcoois combustiveis e industriais, aguardente, cera, além de ser consumida in natura. O bagaço da cana-deaçúcar é fonte para a produção de energia e papel. Os ponteiros da cana podem ser utilizados, ainda, como alimentação animal e para extração de palmito para alimentação humana, Lucchesi (1995). Novas alternativas para subprodutos da canade-açúcar estão em evidência conforme mostra Andrieta (1998), tais como: álcoolquímica produzido a partir do etanol originando etileno, acetaldeído, éter etílico, acetona e clorofórmio; leveduras de panificação, levedura como fonte de proteção como a L-Lisina, glutamato de sódio, ácido citrico, goma Xantana, goma dextrana, adoçantes como sacarose, sucralose e neosugar; açucares especiais como líquidos e invertido. Paixão (1994), cita que, segundo os empresários do setor, a atividade sucroalcooleira absorve $3 \%$ do total de pessoas empregadas nas atividades agricolas em todo o Brasil, somando 800 mil cortadores de cana na safra, 200 mil operários nas agroindústrias e mais 700 mil empregos indiretos.

Pode-se dizer ainda, que a cana-de-açúcar é uma cultura ambientalmente correta. Segundo Macedo (1989), a agroindústria canavieira no Brasil é relativamente "limpa" em relação a impactos ambientais, comparando-a com a maioria das demais atividades agricolas e industriais. A exceção do uso de herbicida, seus pontos positivos no Brasil, ainda, segundo o autor, são os seguintes:

- a produção de cana usa, relativamente, pouco pesticida, trabalhando com extenso programa de controle biológico;

- os insumos fertilizantes são reduzidos, havendo reciclagem de potássio (através da vinhaça) e parte do material orgânico e de outros minerais (através da torta de filtro); 
- o crescimento rápido da planta permite boa cobertura do solo na maior parte do tempo, facilitando o controle da erosão;

- a produção industrial (açúcar e álcool) tem energia fornecida pelo bagaço (renovável);

- os processos industriais utilizam insumos relativamente seguros e os efluentes são recicláveis;

O autor relata, ainda, que o corte manual de cana-de-açúcar exige demasiada mão-de-obra e, considerando que sua substituição pela colheita mecanizada aumenta a produtividade, reduz custos e somados a fatores legais levam a redução gradual e contínua da queima da cana. Atualmente, desenha-se um cenário reforçando a implantação da mecanização da colheita da cana crua. Levantamento feito pelo IDEA (1998), mostra que, apenas, 13,5\% das áreas com cana no Brasil, na safra 1997/98, utilizaram colheita mecanizada, dos quais $15,4 \%$ nos estados do centro-sul do país. Com a chegada ao país de novos modelos de colhedoras, observa-se que são escassas às informações de seus desempenhos operacionais e econômicos. Dentro do contexto apresentado, o presente trabalho tem como objetivo caracterizar o desempenho operacional e econômico de um modelo de colhedora de cana-de-açúcar, operando em canavial sem queima prévia, fornecendo parâmetros e sedimentando métodos que forneçam ao agricultor, informações para a tomada de decisão gerencial sobre custos de colhedoras de cana-de-açúcar.

A hipótese básica é que a variável velocidade de deslocamento, reflete nos desempenhos operacionais e econômicos de colhedoras, sob mesma condição de campo.

\section{REVISÃO BIBLIOGRÁFICA}

\subsection{A colheita da cana}

A colheita de cana-de-açúcar, segundo Bofill et al. (1982), é a atividade que se inicia com o corte da cana no campo e termina quando esta cana chega à indústria, disponivel para moagem .

Pereira (1983) relata que, na década de 60, o setor sucro-alcooleiro, sofreu as primeiras dificuldades de escassez de mão-de-obra, o que o levou a promover fortes mudanças nos sistemas de colheita. As mudanças iniciaram-se no sub-sistema de carregamento da matéria prima às unidades transportadoras, o qual passou a ser 
mecânico, alterando também, o processo operacional de colheita na formação dos eitos, passando para 5 fileiras de plantio das três utilizadas anteriormente. No corte, ocorreu a substituição da despalha manual pela queima prévia dos canaviais, promovendo, assim, melhor limpeza, provocando um aumento de desempenho, em média, de 1,5 toneladas para 5 toneladas.

Para as operações de corte, carregamento e transporte da cana, podem ser utilizados diferentes métodos, podendo ser manuais, mecânicos ou misto, cana queimada ou não, com ou sem desponte, corte de 5 ou 7 fileiras, entre outros, Luz (1989).

Câmara \& Oliveira (1993), definem a colheita da cana-de-açúcar como sendo um processo dinâmico que permite o fornecimento de matéria-prima e envolve desde o planejamento de queima e corte até a entrega da cana na esteira de moagem da usina ou destilaria.

Lopes (1995) mostra que a colheita da cana-de-açúcar é uma atividade complexa, custosa e que para o seu planejamento, devem ser considerados fatores edafoclimáticos, vegetativos e de disponibilidade de recursos.

Segundo Belodi (1998), a atividade da colheita de cana-de-açúcar (considerando-se corte manual de toda a cana, sendo $90 \%$ dela queimada e $10 \%$ crua, além de transporte por treminhões num raio médio de 27 quilômetros), representa $38 \%$ do custo de produção da cultura.

\subsection{Histórico da mecanização da colheita de cana}

Segundo Furlani Neto (1984) citando relatos históricos, informa que a primeira máquina cortadora de cana foi patenteada em 1854 no Havaí, era tracionada por uma parelha de muares e, além de cortar a cana, removia folhas e palhas dos colmos com uma escova de arame. Já a mecanização da colheita no Havaí iniciou-se em 1906, quando foi introduzida a primeira cortadora autopropelida como descrito por Hubert (1974). O autor descreve que em 1925, foi nomeado um comitê pela associação dos usineiros do Havaí para estudar "dispositivos econômicos do trabalho", tendo sido posteriormente identificados 286 tipos diferentes. Em 1937, tal comitê desenvolveu o primeiro protótipo integrado de colheita, visando suprir a escassez de mão-de-obra e reduzir o custo do corte manual.

Ripoli \& Villanova (1992), mostram que no Brasil tem-se registro de uma 
primeira experimentação de uma máquina importada para corte de cana em 1956, seguida em 1962, de uma iniciativa pioneira para desenvolvimento de uma cortadora amontoadora por uma empresa em Piracicaba - SP, sendo que a história da mecanização do corte da cana-de-açúcar no Brasil em escala comercial, deu-se em 1973 em São Paulo pela empresa Santal Equipamentos S/A, com fabricação nacional utilizando tecnologia importada.

\subsection{A queima prévia da cana}

Segundo Costa Filho (1979), a atividade de queima prévia dos canaviais não trás prejuizo ao solo e garante um aumento no desempenho do corte.

Delgado (1985), citou os principais pontos positivos e negativos da prática da queima da cana antes da colheita, conforme se segue:

i) aspectos positivos:

- facilita as operações de preparo de solo e de cultivo;

- aumenta o teor de cinzas do solo;

- facilita a operação de corte tanto manual como mecanizado;

- provoca aumento aparente dos teores de brix, sacarose e de fibra em porcentagem, devido ao ressecamento dos colmos;

- torna a operação de colheita menos custosa em função de facilitar tanto o processo de corte mecanizado como o do corte manual;

ii) aspectos negativos:

- destrói os inimigos naturais da broca da cana-de-açúcar;

- a palha poderia ser incorporada ao solo, aumentando seu potencial de matéria orgânica;

- o caldo de canaviais previamente queimados apresenta dificuldades na conservação e purificação, em função do tempo de exposição dos colmos após a queima;

- eleva a taxa de microorganismos em função da esudação do caldo nos colmos, predispondo-os à perda de sua qualidade;

- Os maiores custos ocorrem em canaviais que foram previamente queimados e cujos colmos demoram a ser entregues à indústria; 
- as queimadas das palhas desperdiçam cerca de $30 \%$ do peso da matéria bruta ou $15 \%$ da matéria seca, que poderia ser aproveitado como fonte de energia nas caldeiras.

Payne (1986), mostra que os efeitos da queima prévia da cana-de-açúcar, do ponto de vista das perdas de energia e açúcares, pode implicar em redução de até $50 \%$ da biomassa da planta bem como reduções não despreziveis no teor de sacarose.

A queima prévia caracteriza-se por ser uma eficiente operação de limpeza do canavial, influindo positivamente no desempenho da operação de corte manual, reduzindo o esforço físico dos trabalhadores, aumentando a capacidade de trabalho, reduzindo a incidência de animais $e$ insetos peçonhentos e aumentando a disponibilidade da mão-de-obra, Ripoli \& Mialhe (1987).

Ripoli \& Ripoli (1995) em estudo feito para verificação de temperaturas durante as queimadas da cana-de-açúcar, obtiveram, temperaturas em ${ }^{\circ} \mathrm{C}$, a $1 \mathrm{~m}$ de altura do solo dentro do canavial, $1 \mathrm{~m}$ de altura do solo dentro de um colmo e a $2,5 \mathrm{~cm}$ de profundidade no solo, antes e durante a queima de: 20,813 durante $2 \mathrm{~s} ; 21,50 ; 17,18$, respectivamente. Os autores concluíram que o solo sofre menos o efeito das queimadas.

Bellodi (1988), descreve que a prática da queima prévia da cana-de-açúcar é feita para reduzir a palhada e executada em horários impróprios, geralmente durante o dia reduzindo, sensivelmente, o resíduo vegetal e incorrendo no problema da exudação dos colmos, contribuindo para perdas no processo industrial.

Melo et al. (1988) mostram os valores de alguns parâmetros, correspondentes a cana queimada e despontada : Brix: 15,9\%; Pol por cento do caldo: 13,01; Pol por cento da cana: 11,20; Fibra por cento da cana: 13,90; Pureza: 81,99\%.

Stupiello (1989), destaca alguns aspectos ligados a qualidade da matériaprima, resultando em perdas de açúcares após a queima prévia da cana, classificando três tipos de deterioração existentes, microbiológicos, tecnológicos e fisiológicos; a primeira oriunda da inoculação nas rachaduras dos colmos (microfissuras) feita pelo fogo, a segunda oriunda da exudação e aumento da porcentagem de fibra da cana e a última oriunda da utilização dos açúcares para reativar as atividades fisiológicas da planta em função do tempo de exposição da planta no solo após a queimada.

Furlani Neto (1991) informa que, na região Centro-Sul do país, é pratica 
tradicional a queima dos canaviais para o posterior corte e carregamento, e que algumas variedades favorecem a ação do fogo na eliminação de folhas ou palhas não desejáveis do canavial, melhorando o desempenho operacional do corte manual.

Kirchoff (1992) mostra que, as queimadas existentes no Brasil que acontecem nos cerrados, nas vegetações a beira das estradas e na palha da cana-de-açúcar que antecede sua colheita, contribuem indiretamente para o aumento do efeito estufa no planeta, através da emissão de óxido nitroso $\left(\mathrm{N}_{2} \mathrm{O}\right)$, metano $\left(\mathrm{CH}_{4}\right)$ e a liberação de monóxido de carbono (CO), destrói também a camada de ozônio na atmosfera.

Urquiaga et al. (1997) afirmam que, além das perdas em nutrientes do solo, a queima da palha da cana-de-açúcar lança na atmosfera cerca de 64,8 milhões de toneladas de gás carbônico por ano, no Brasil, o que contribui para piorar a qualidade do ar nas cidades e ao aumento do efeito estufa na baixa atmosfera.

\subsection{Aspectos legais, ambientais e ocupacionais}

Cabe citar a proibição das queimadas no Estado de São Paulo, criada pelo Decreto Estadual $n^{0} 42.056$, de 06/08/97, que afeta a pratica da despalha da cana por queima prévia, extinguindo esta prática no prazo de 8 anos nas áreas mecanizáveis (até $12 \%$ de declividade) e de 15 anos nas áreas não-mecanizáveis (declividade maior de $12 \%$ ). Este decreto altera a redação do artigo $5^{\circ}$ do decreto $n^{0} 41.719$ de 16 de abril de 1997 que regulamentou a lei $n^{0} 6.171$ de 04 de dezembro de 1988 , alterada pela lei n 8.421 de 23 de novembro de 1993, que dispõe sobre o uso, conservação e preservação do solo agrícola. O decreto foi conseqüência direta de pressões da sociedade com relação aos problemas de poluição ambiental, prioritariamente através da atuação sistemática do Ministério Público, respaldado na reforma constitucional de 1989, que se valia do Decreto Estadual $n^{0} 28.895$ de 20/09/88, e da Lei federal $n^{0}$ 8.943 , de 29/09/94, para coibir as queimadas judicialmente.

No âmbito federal, publicado no Diário Oficial da União, o decreto $n^{0} 2.661$ de 08 de julho de 1998 que regulamenta o parágrafo único do artigo 27 da lei $n^{0} 4.771$ de 15 de setembro de 1965 (código florestal), mediante o estabelecimento de normas de precaução relativas ao emprego do fogo em práticas agropastoris e florestais, ampliando o prazo das queimadas para 20 anos.

Este decreto federal, em seu capitulo IV, artigo 16, aborda o emprego do fogo como método despalhador e facilitador do corte da cana-de-açúcar, em áreas 
passiveis de mecanização da colheita e sua eliminação gradual, e o artigo 17, aborda a obrigatoriedade dos órgãos governamentais competentes em fazer uma avaliação e ajustes das conseqüências sócias econômicas a cada 5 anos.

Segundo Nunes Junior (1998), quando o estado possui uma legislação específica, esta prevalece sobre a federal, desde que não contrarie a Constituição Federal. Portanto no Estado de São Paulo, o que prevalece é 8 anos para áreas de até $12 \%$ de declividade e 15 anos para áreas com declividade acima de $12 \%$.

Em 04 de junho de 1998 , foi emitida a resolução conjunta SAA/SMA 1, de 04 de junho de 1998, do Estado de São Paulo, os procedimentos relativos ao disposto no decreto Estadual n 42.056, de 06/08/97; que entre outros, define o plano de eliminação de queimadas (P.E.Q.), onde os produtores de cana-de-açúcar são obrigados a elaborar seus planos e entrega-los nos prazos estabelecidos; este plano é fiscalizado pela CETESB e seu não cumprimento ocasiona pesadas multas.

Parte da motivação do Ministério Público para fazer cumprir tais leis, foram posições de estudiosos da área da saúde, como Zamperlini et al. (1997), que utilizando métodos cromatrográficos e espectométricos na fuligem da cana-de-açúcar durante as queimadas, detectou a presença de substâncias, sabidamente carcinogênicas, tais como: hidrocarbonetos alifáticos, ésteres de ácidos graxos, tiofenos e hidrocarbonetos policíclicos aromáticos. Bohm (1998), diz que é intuitivo que as queimadas de cana provoquem patologias, mesmo afirmando que, até o momento, não existam pesquisas que comprovem este fato. O autor mostra que a inalação de fuligem da queima da cana e outros gases associados, podem provocar patologias como: inflamação das vias aéreas, infecção por microorganismos existentes nas vias aéreas ou inaladas, neoplasias das vias respiratórias entre outros.

Arbex, Conceição \& Saldiva ${ }^{1}$, citados por Bohm (1998), mostram o trabalho realizado na região de Araraquara-SP, apresentando uma correlação positiva entre os dados de procura de socorro hospitalar (aumento de $20 \%$ ) e a época de queimada da cana-de-açúcar.

\subsection{Colheita da cana crua}

Bassinelo et al. (s.d.), mostram que a colheita da cana-de-açúcar sem queima

\footnotetext{
${ }^{1}$ Arbex, Conceição \& Saldiva. Citados por Bohm (1998), Queima de cana-de-açúcar e Saúde Humana.
} 
prévia apresenta vantagens e desvantagens. A palha e o palhiço deixado no campo após o corte propiciam uma melhor manutenção da umidade no solo, uma eventual resistência à compactação por máquinas de corte e carregamento, maior resistência à erosão do solo decorrente das gotas de chuva, um aumento da matéria orgânica no campo e a redução da poluição atmosférica provocada pela queima da cana. Como desvantagem apontam entre outros, o aumento de matérias estranhas minerais e vegetais junto à matéria-prima, maior foco de infestação para alojamento de pragas, perigo de fogo acidental no período da entre safra e durante a colheita, maior velocidade de deterioração da cana crua em relação à queimada após o corte e maior incidência de animais peçonhentos no momento do corte, provocando acidentes ocupacionais.

Peixoto \& Delgado (1988), estudando as operações agrícolas na cultura da cana-de-açúcar comentam que os desempenhos médios obtidos para o corte em canaviais sem queimar variam de 2 t.homem. dia ${ }^{-1}$ para operários, fracos de baixo nivel de experiência e, 4 thomem. dia ${ }^{-1}$, para operários mais fortes e hábeis, em canaviais de médias e altas produtividades, obtém-se de 3 a 4,5 t.homem.dia ${ }^{-1}$.

Churchward \& Pousen (1988), relatam os beneficios observados com a colheita de cana crua, nos aspectos agronômicos pela manutenção dos residuos provenientes da colheita sobre o solo tais como: conservação da umidade, controle de crescimento do mato, economia das operações de cultivo, perfilhamento e brotação das soqueiras, e um tráfego menos traumático para o solo. Melo et al. (1988), apresentaram alguns parâmetros correspondentes à cana crua e despontada : Brix: 18,0\%; Pol por cento caldo: 15,9; Pol por cento cana: 13,96; Fibra por cento cana: 12,19; Pureza: 88,34\%. Os mesmos autores observam que no corte da cana crua quando comparada à cana com queima prévia apresenta um acréscimo de biomassa proveniente da matéria prima em torno de $20,6 \%$.

Delgado \& Mafra (1989), estudando a cana crua inteira e com desponte que são transferidas às usinas, afirmam que é uma matéria-prima de difícil manuseio pela grande quantidade de folhas presentes e em virtude da não ocorrência da queima, sendo constituida basicamente de colmos, folhas laterais, palmitos e ponteiros apicais constituido de folhas e inflorescências.

Furlani Neto (1991) escreveu que os desempenhos obtidos para o corte manual de cana crua para mudas, na região Centro-Sul do pais, têm variado entre 2,5 e 3,0 
toneladas por homem por dia. Para canaviais queimados, o desempenho se eleva para 5,0 a 7,0 toneladas por homem por dia no corte, com desponte e 7,0 e 8,0 no corte, sem desponte.

Cerqueira Luz \& Aloisi (1991), estudando o percentual do teor de fibra em colheita mecanizada de cana-de-açúcar sem queima prévia, obtiveram, em média, o valor de $15,65 \%$.

Ruiz \& Orosco (1992), descrevem que a adoção do sistema cubano de colheita de cana crua a partir dos anos 80 , surgiu para sanar problemas causados pelas queimadas que provocavam a diminuição significativa nas produtividades agrícolas e rendimentos industriais, estragos nos solos e uma crescente contaminação ambiental.

Ripoli \& Villanova (1992), mostram que as colheitas da cana crua, evitam um desperdício de energia produzido pela queima do palhiço (pontas, folhas verdes e palha), que representa, em média, $32,5 \%$ da biomassa produzida por um canavial.

Os mesmos autores citam vantagens e desvantagens do sistema de colheita da cana crua; como vantagem citam que o palhiço que fica sobre o solo após a colheita diminui ou até elimina o uso de herbicidas; mantém por mais tempo a umidade do solo e atuam como eficiente mecanismo de controle de erosão; não destrói o inimigo natural da broca e, sob o ponto de vista industrial, favorecem uma menor perda de sacarose; diminuem os problemas no tratamento de água de lavagem e o aproveitamento parcial do palhiço que, associado ao bagaço, otimizam a co-geração de energia elétrica. Como desvantagem apontam um maior esforço físico dos trabalhadores braçais, aumento nos riscos de acidentes ocupacionais, aumento na quantidade de matéria estranha vegetal recebida pela usina, redução do desempenho operacional dos trabalhadores, com aumento marcante dos custos por tonelada cortada sinalizando a necessidade de mecanização e maior foco de infestações de pragas e doenças.

Ripoli at al. (1995) mostrou que, o desempenho do corte manual de cana crua, com relação à queimada, cai entre 1,8 e 3,6 vezes, dependendo da variedade cortada; logo, o ganho diário do cortador se reduz entre $32 \%$ e $40 \%$. Para equiparar-se ao ganho normal com o corte de cana queimada, a diária para corte de cana crua deveria ser aumentada entre $60 \%$ e $68 \%$, encarecendo os custos da operação, assim, o corte de cana crua acaba induzindo à mecanização da colheita.

Ripoli \& Ripoli (1996) em estudo na região de Piracicaba-SP, para caracterização dos principais constituintes da biomassa de cana-de-açúcar sem 
queima prévia, obtiveram, em \%, para as variedades SP801842, RB72454, Colmos Industrializáveis: 78,98 e 83,21; Ponteiros: 5,91 e 4,32; Folhas Verdes: 7,53 e 3,95; Palhas: 7,67 e 8,52 e Indice de Palhiço: 26,76 e 20,18, respectivamente. Os autores concluíram, que é significativa a quantidade desperdiçada desta biomassa para o aproveitamento energético.

Ripoli (1999), mostra que o aproveitamento do binômio bagaço-palhiço, pela industria sucroalcooleira, decorrente da colheita de cana crua, não somente aumenta sua rentabilidade econômica como implementa o desenvolvimento auto-sustentável. Mostra que, apenas no Estado de São Paulo, que tem um consumo per capta de 8,33 kWh. dia ${ }^{-1}$ na forma de energia elétrica, o aproveitamento do palhiço para geração da eletricidade poderia abastecer por volta de 7,5 milhões de pessoas/ano, sendo que o aproveitamento do bagaço da cana poderia fornecer quantidade de energia equivalente.

\subsection{Colheita mecanizada}

Para Mialhe \& Rípoli (1976), constitui fato amplamente conhecido que o aumento da produção de açúcar e de álcool tem sido obtido pela ação conjunta de dois fatores: emprego de tecnologias mais avançadas e abertura de novas áreas de cultivo. Os autores relatam, "Em ambos os casos, há necessidade de aplicação de recursos extras, fato que contribui para a tendência generalizada de elevação dos custos de produção, a fórmula preconizada comumente para restringir essa tendência, tem sido a racionalização do processo de produção, particularmente no que diz respeito à organização, controle e administração de maquinaria. No cultivo de cana-de-açúcar, a mecanização racional das operações do preparo do solo, de plantio, de adubação, de aplicação de pesticidas e de cultivo, apresenta um grau de complexidade bem menor, em comparação com a operação de colheita. $O$ processo de mecanização da colheita de cana-de-açúcar não é, simplesmente, uma substituição do trabalho manual pelas máquinas; atinge as dimensões de um sistema, cujos limites são bastante amplos para incluir toda a problemática de transferência de matéria-prima, do campo para a fábrica. Nesse sistema pode-se visualizar três sub-sistemas: corte e carregamento; transporte; e recepção".

Os mesmos autores consideram que os sub-sistemas, "Embora contenham uma parte especifica da problemática global, apresentam interfaces que incluem 
aspectos de interesse comum. Forma-se assim, uma cadeia de vinculação entre o campo e a fábrica, através da qual se estabelece o fluxo de matéria-prima que alimenta a indústria. Portanto, o objetivo fundamental dos estudos e pesquisas que se realizam sobre o sistema de colheita mecanizada de cana-de-açúcar é em última analise, a otimização desse fluxo para as condições particulares de cada empresa produtora de açúcar e álcool, visando:

- qualificação da matéria-prima, em termos de manutenção do teor de açúcar nos niveis originais do campo e de redução do grau de deterioração durante o fluxo;

- limpeza da matéria-prima em termos de redução de matéria estranha;

- custo de transferência de matéria-prima do campo para a indústria, em termos de redução no custo da unidade de intensidade de fluxo.

A aceitação dessa tese, da otimização de fluxo de matéria-prima, resulta numa definição clara e objetiva das diretrizes básicas que orientam estudos e pesquisas seja em nivel acadêmico ou gerencial, sobre a maquinaria utilizada em cada um dos subsistemas anteriormente citados".

Fernandes \& Oliveira (1977), mostram que apesar do uso de colhedoras de cana terem solucionado parte do problema da mão-de-obra para a colheita, houve uma alteração negativa da qualidade da matéria-prima colhida e sua conseqüente implicação nas diversas partes da industrialização. Os autores mostram que esta alteração negativa da qualidade é devido ao sistema das colhedoras combinadas tipo "corta-pica-limpa-carrega".

Furlani Neto et al. (1978), diz que o comportamento de uma colhedora autopropelida, depende das características de seus componentes mecânicos e o seu trabalho é função de fatores técnicos, administrativos e das condições do canavial onde irá operar. Para Ripoli \& Paranhos (1987), em níveis internacionais, o desenvolvimento de estudos e projetos de máquinas para a colheita de cana-de-açúcar ocorreu basicamente por dois fatores: o primeiro, à crescente dificuldade e encarecimento da mão-de-obra para o corte manual $e$, o segundo, ao interesse na obtenção de aumentos nos desempenhos das operações de colheita, com seu esperado barateamento. O exemplo mais marcante disso é a situação encontrada na Austrália, em que a colheita é virtualmente processada mecanicamente em $100 \%$ da área de cana-de-açúcar, a qual não possui limitação de relevo. Para esses autores, a estação da colheita de cana-de-açúcar tem um significado todo especial para a 
agroindústria açucareira, não apenas pelo fornecimento de matéria-prima para a fabricação de açúcar, mas também por evidenciar o resultado econômico da empresa tanto pela produção quantitativa como qualitativa da matéria-prima.

Tal colocação é válida atualmente em nível de destilarias de álcool. Esses autores afirmam, ainda, que, do ponto de vista econômico, o corte, o carregamento e transporte de matéria-prima absorvem em torno de $50 \%$ das despesas totais da produção agrícola, refletindo o seu papel bastante destacado no balanço econômico das empresas.

Noa (1992) relata que em Cuba, a partir da colheita mecanizada de cana crua é importante a recuperação da biomassa associada às folhas e paihas. $O$ autor mostra que a colheita da cana crua chega a ser de $90 \%$ das áreas cultivadas, sendo que, $74 \%$ destas áreas utilizam colheita mecanizada; uma parte da palha fica no campo permitindo a conservação da umidade, reposição de nutrientes e redução do uso de herbicidas e a outra parte é recuperada como combustivel em caldeiras, na produção de bio-fertilizantes ou como alimento para o gado.

Câmara \& Oliveira (1993), dizem que dentro do mercado brasileiro, são poucas as marcas e modelos de colhedoras autopropelidas, quando comparado aos países que, tradicionalmente, utilizam a colheita mecânica da cana de açúcar, e que, basicamente, estas colhedoras realizam as seguintes operações: corte do ponteiro (despontador ou cortador superior), levantamento de canas acamadas (espirais alimentadores ou "pirulitos"), corte basal, limpeza da terra agregada aos colmos ou rebolos, corte em rebolos de tamanho variável, limpeza de folhas ou palhas (através de extratores ou ventiladores), elevação dos rebolos ou colmos (através de rolos, esteiras ou rotores), descarga dos colmos em caminhões ou carretas teladas.

Ruiz \& Orosco (1999), mostram que, em Cuba, atualmente, os sistemas de colheita de cana crua representam a maior safra mecanizada do mundo, com a colheita de aproximadamente 1,75 milhões de hectares; através de: 4.000 colhedoras, 20.000 tratores, 30.000 carretas agrícolas, 7.000 caminhões e 1.000 composições ferroviárias. Os autores mostram, ainda, que as tecnologias fundamentais associadas ao sistema cubano são: sistematização das áreas canavieiras para a colheita mecanizada, preparo localizado dos solos e cultivo minimo e tratos culturais compreendendo o cultivo, a fertilização, aplicação de herbicidas e fertilizantes para a cana colhida crua. Os mesmos autores, afirmam que a definição de um sistema, 
método ou esquema de colheita de cana-de-açúcar, se encontra estreitamente vinculada às condições sócio econômicas do país ou região onde se aplica e é evidentemente que, nas atuais circunstâncias em Cuba, somente a colheita mecanizada pode assegurar maior eficiência e menores custos. Os autores afirmam, ainda, que a colheita de cana crua com a utilização de colhedoras de processo completo e estações de limpeza, permite obter cana entrando na usina com menos de $5 \%$ de matéria estranha. Magro (1999) afirma que a partir de 1979, na Austrália, toda a cana de açúcar passou a ser colhida mecanicamente, ainda utilizando a queima prévia. A adoção do novo sistema de colheita, sem a queimada da palha, foi facilitada por existirem boas colhedoras para operar em cana com palha e, hoje, representam $70 \%$ da área canavieira do pais, apesar das perdas de matéria-prima chegarem a $12 \%$.

\subsection{Fatores envolvidos na seleção e na Capacidade Operacional das colhedoras}

Ripoli \& Paranhos (1987), citam os fatores que devem ser levados em conta e que interferem na Capacidade Operacional e na utilização das máquinas cortadoras e colhedoras, podendo ser agrupadas em três áreas, a saber:

fatores da máquina, que diz respeito as suas características do projeto; fatores de campo, que diz respeito às condições de campo em que a máquina ira operar e fatores de ordem administrativa, que diz respeito a aspectos gerais e de planejamento.

Segundo os autores cima, os fatores de máquina contemplam:

O C.G., o qual Interfere na utilização e capacidade operacionais dessas máquinas como em qualquer outra fonte de potência móvel. Quanto mais elevado for o centro de gravidade menor será a utilização da maquina em função do relevo do terreno; quanto a capacidade operacional pode haver decréscimo, pois, há tendência de diminuir-se a velocidade de deslocamento a medida em que o C.G. é mais elevado, aumentando-se as condições de instabilidade e dificultando a operação.

Geralmente essas máquinas, segundo especificações dos fabricantes, podem trabalhar com velocidade de até $9 \mathrm{~km} \cdot \mathrm{h}^{-1}$. Mas, atualmente no Estado de São Paulo, as colhedoras e cortadoras não têm ultrapassado, em trabalho, a velocidades de 3 a 5 $\mathrm{km} \cdot \mathrm{h}^{-1}$. As características dos processos de levantamento das canas acamadas onde determinadas máquinas não possuem meios para este levantamento; com isso já ocorre uma limitação em seu uso (só trabalharão com certa eficiência em canas eretas). As caracteristicas dos processos de corte em rebolos e ventilação (limpeza), 
devem apresentar uma certa padronização de tamanho a fim de que, quando passarem, pelos órgãos de limpeza, (o qual se processa também por meio de ventiladores e/ou exaustores de alta potência), a separação entre eles e a matéria estranha (por diferenças de densidade), não ocorra inadequadamente. Sem essa padronização, pode ocorrer que rebolos sejam eliminados e ponteiros de colmos sejam colocados junto à matéria-prima no transporte, e vice-versa. Da mesma forma, se os ventiladores ou exaustores não forem devidamente dimensionados, ocorrerá um agravamento dessa situação, a qual, sofre ainda as interferências da própria variedade de cana cortada. A potência nas colhedoras e cortadoras varia, em média de 40 a 220 c.V., sejam autopropelidas ou montadas em tratores; fica claro que, em função desse fator uma colhedora terá maior ou menor utilização a capacidade operacional, em função da produtividade agrícola do canavial.

Geralmente, as colhedoras requerem maior potência porque além da exigência para o deslocamento, há um grande consumo de potência para o acionamento de vários motores, bombas e cilindros hidráulicos que fazem parte do seu conjunto orgânico, bem como para acionar os dispositivos de transporte de matéria-prima, desde o corte basal (inicio de operação), até a colocação na mesma unidade de transporte (final da operação).

Os rodados que existem atualmente nas colhedoras são de pneus, esteiras e semiesteiras; máquinas com rodados de esteira poderão operar em condições mais severas de relevo e em solos com teores mais elevados de água. Dependendo do tipo de solo e do rodado da máquina, haverá maior ou menor compactação do terreno. No Brasil atualmente existem máquinas com rodados de pneus e de esteiras.

Os fatores de campo, contemplam: Variedade, onde as características desejáveis a serem ensaiadas na seleção de cana-de-açúcar são a produtividade agrícola elevada (t.ha ${ }^{-1}$ ), o alto teor de sacarose (\%pol), precocidade de maturação, longo periodo de maturação, boa brotação e longevidade das socas, não florescimento excessivo, baixo indice de tombamento, resistência satisfatória as principais pragas e doenças e facilidade para a colheita mecânica. Embora os equipamentos de colheita tenham evoluido bastante do ponto de vista operacional, permitindo a operação em canaviais antes considerados inadequados para a colheita mecanizada, é certo que a eficiência do corte e limpeza dos colmos é aumentada quando há facilidades para o desenvolvimento do processo. Colmos eretos, com boa despalha podem, inclusive, 
proporcionar corte em cana crua. Isso viabilizaria o corte de áreas próximas aos centros urbanos, onde a queima da cana já é proibida.

Segundo Ripoli \& Paranhos (1987), as características morfológicas e fisiológicas das variedades interferem bastante no corte mecânico de cana-de-açúcar. Em principio, tanto as colhedoras como as cortadoras operam melhor em canas eretas, vigorosas e de sistema radicular profundo; eretas a fim de facilitar o corte da base e do topo, havendo com isso, um ganho na capacidade efetiva de campo das máquinas (poderão trabalhar sem maiores interrupções), uma menor perda em canas não cortadas e melhor limpeza; vigor e sistema radicular profundo porque o corte mecânico basal resulta da ação de uma ou mais lâmina e exige uma certa resistência de ancoramento da cana para ocorrer o cisalhamento, caso a cana possua sistema radicular superficial e não seja vigorosa, pode ocorrer um corte imperfeito ou um corte dilacerante, praticamente destruindo aquele internódio e como conseqüência ter-se-ia a aumento da área de infecção e maior deterioração, como também, maior probabilidade de infecção e destruição da soqueira, com redução do brotamento subseqüente.

As variedades, segundo os mesmos autores, como as desenvolvidas na Austrália com pouco ponteiro são mais desejáveis ao corte mecânico. Elas ocorrem também em Porto Rico e Hawai, sendo de características tropicais. Em contrapartida, as variedades brasileiras de uma maneira geral, possuem ponteiros mais longos o que implica em dificuldade dos exaustores e ventiladores (órgãos de limpeza) fazerem a separação por diferença de densidade, visto que palmitos maiores podem equivaler em peso, aos rebolos. Aumentando-se a rotação do trabalho do exaustor, com certeza os rebolos também serão eliminados e diminuindo-se essa rotação os ponteiros serão incluídos à matéria- prima.

A sanidade da cultura também pode interferir na qualidade do corte mecânico. Por exemplo, colmos atacados intensamente pela "broca da cana" (Diatrea e Saccharalis) apresentam galerias em seus internódios o que irá ocorrer para uma maior facilidade de se quebrarem na primeira fase da limpeza (em determinadas máquinas), com isso a matéria-prima é perdida em baixo dessas máquinas.

É interessante, tanto para as colhedoras como as cortadoras que o talhão a ser trabalhado seja homogêneo no que diz respeito a altura das canas e no perfilhamento das soqueiras. Em nossos canaviais, regra geral, não é muito comum se encontrar tais 
condições, visto que as variedades atualmente em uso no Brasil não foram desenvolvidas para serem cortadas ou colhidas mecanicamente, além do fato de haver grande variação nas técnicas culturais adotadas, em que a distribuição do adubo se evidencia como irregular ou não uniforme, prejudicando e dificultando aquela homogeneização. O reflexo disso é que a máquina não é alimentada uniformemente, trabalhando sem um fluxo constante de cana o que faz diminuir a sua capacidade operacional. Quanto a não uniformidade da altura, também causa prejuízo ao trabalho pois, o operador dificilmente poderá controlar com perfeição o corte dos ponteiros, ocorrendo por vezes, a eliminação de internódios e por outra a não eliminação de ponteiros, dificultando inclusive as regulagens do sistema de ventilação da máquina.

Alta produtividade, além de 130 t.ha $^{-1}$, Ripoli (1996), para a maioria das atuais colhedoras de cana-de-açúcar pode fazer baixar a capacidade efetiva da máquina por redução da velocidade do deslocamento e concorre para um aumento das probabilidades de embuchamento. O estado do canavial como visto anteriormente, à medida que se ache mais uniformemente perfilhado, mais ereto e mais uniforme em altura dos colmos, proporcionará melhores condições de trabalho a máquina, podendo então, desenvolver maiores velocidades e oferecer matéria-prima de melhor qualidade, havendo ainda menor possibilidade de embuchamento da mesma.

Ripoli et al. (1977), adotaram um critério para definir o que são colmos eretos, acamados a deitados, como são mostrados a seguir:

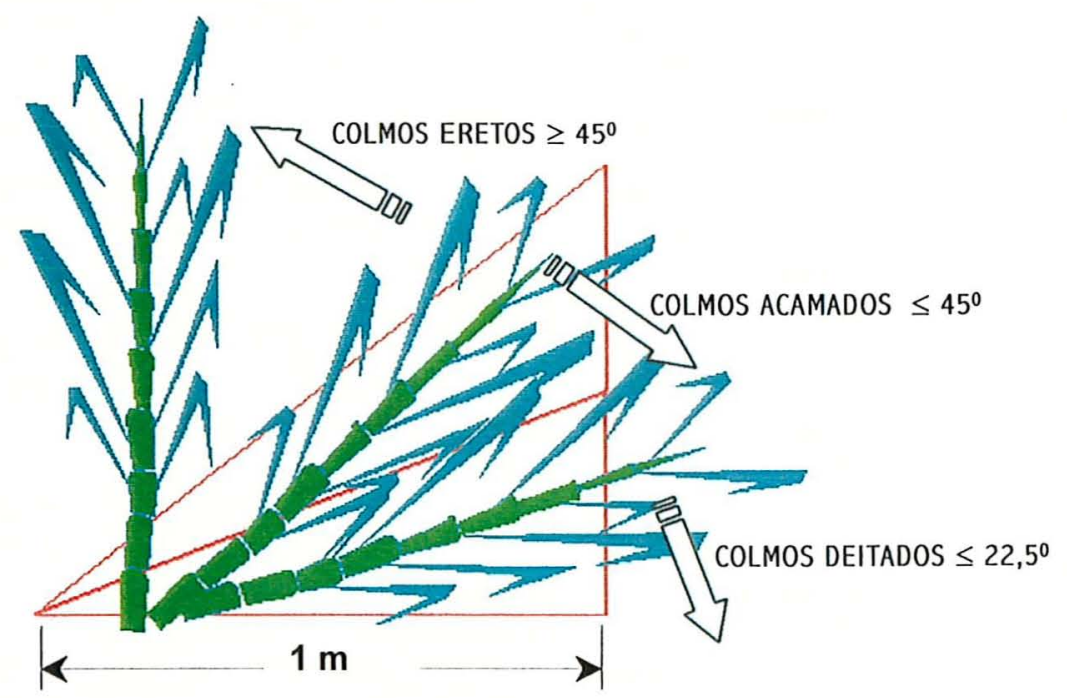

Figura 1. Triângulo padrão, para determinação do porte do canavial. (Ripoli et al. 1977). 
Para a caracterização de um talhão, tomam-se 20 amostras.ha ${ }^{-1}$, de $1 \mathrm{~m}$ linear de sulco, contando-se os colmos em cada condição e determinando-se suas porcentagens. Outros fatores importantes são o preparo de solo, o sistema de plantio e o espaçamento.

O corte basal é realizado através de um ou mais discos rotativos com laminas, tanto nas cortadoras como nas colhedoras.

Apesar do conjunto possuir acionamento hidráulico permitindo variação de altura de corte basal, ele é projetado para cortar os colmos em um ponto um pouco acima do nível do terreno, ou seja, a touceira devera estar sobre um leve camalhão; sendo interessante ressaltar que determinados fabricantes de máquinas para corte $e$ colheita de cana-de-açúcar estão desenvolvendo estudos para que máquinas realizem o corte basal mesmo em touceiras que estejam dentro do sulco.

Devido às práticas de preparo de solo em uso no Brasil não serem voltadas para a colheita ou corte mecanizado, raramente encontra-se tal condição na canaplanta ou na soqueira de primeiro corte; e não havendo, ocorre que, se estiverem em camalhões (canas mais velhas), corre-se o risco da destruição da soqueira com o corte, ocasionando falhas na próxima brotação. Existe também o inconveniente da máquina operar com os pneus em desnivel em camalhões, ocasionando serviço insatisfatório. Como as laminas irão trabalhar sob o solo, surge o problema de maior desgaste por abrasão das mesmas e de todo o mecanismo de condução do material cortado, na máquina. Por outro lado, estando as fileiras de plantio no sulco, não haverá possibilidade da máquina cortar na altura desejada (ao nível da soqueira), havendo maior dilaceramento dos internódios do que, propriamente um cisalhamento, que seria o desejado. O fato se deve, principalmente, à maior resistência do ancoramento pelo colmo ao corte, proporcionando uma situação que leva a sensíveis perdas de matériaprima.

Os fatores de ordem administrativa contemplam:

Retaguarda de reparos e manutenção, devendo fornecer a máquina, reparos e manutenções rápidas e eficientes, a fim de diminuir seu tempo ocioso, aumentando seu custo hora com a queda de sua capacidade operacional.

Gentil (1977), apontou que a otimização da operação da colheita mecanizada envolvia a constituição de uma frota composta por veículos de manutenção em campo para trocas de óleos lubrificantes, graxas e fluidos hidráulicos, abastecimento de 
combustivel, contendo ferramentas e peças de reposição à pronta disposição, junto com o carro oficina, para atender as colhedoras nos serviços necessários. Esta frota deveria ser composta também por um carro pipa para lavagem das colhedoras antes dos serviços de lubrificação, trocas de peças e possíveis incêndios entre o palhiço e as máquinas. Outro fator de ordem administrativa importante, é o da aptidão do operador da colhedora, visto que a máquinas tem preços de aquisição elevados e controles de operação bastante sofisticados. Nota-se que operadores especialmente qualificados e com experiência não somente protegem este bem de capital, diminuindo sensivelmente o número de reparos por operações não corretas, como obtém uma maior capacidade operacional da máquina. A inabilidade do operador também contribui, de maneira significativa, para o aumento de matéria estranha na carga carregada.

O fator relacionado aos tipos de transporte também é considerado de ordem administrativa, visto que o sistema de colheita mecanizada, segundo Ripoli (1974), é um sistema complexo de operações com subsistemas e interfaces exigindo um perfeito sincronismo entre eles, a fim de proporcionar a maior eficiência possível entre o corte da cana no campo até sua entrega na usina. O perfeito sincronismo entre todos os subsistemas e interfaces deve proporcionar a não interrupção da colhedora por falta de transporte, além de otimizar em um menor número de unidades de transporte por colhedora, com reflexos positivos no custo do sistema.

\subsection{A sistematização da lavoura como pré-requisito à colheita mecanizada}

A operacionalização da colheita mecanizada pôs em cheque os tradicionais mecanismos de conservação de solo e sistema viário das propriedades canavieiras, principalmente com o advento da cana crua, que mantém uma camada protetora de palha sobre a superfície do solo.

Segundo Mialhe et al. (1994), o formato de talhão que mais se enquadra na mecanização é o modelo de trabalho em faixas, ou seja, o traçado acompanha as curvas de nivel. O tamanho destes não deve ultrapassar a relação de $1 / 5$, logo a largura não deve ser 5 vezes menor que o seu comprimento. Desta forma, as manobras de máquinas dentro dos talhões serão reduzidas. O comprimento dos talhões pode ser aumentado para 1.000 metros até 1.500 metros, desde que as operações de plantio, aplicação de adubos e resíduos, e tratos culturais das soqueiras não sejam comprometidos. Câmara \& Oliveira (1993), relatam que já em 1966 
apregoava-se a importância da adaptação do campo às condições de máquina, enfatizando que as características de campo deviam-se engrenar com as exigências da colheita mecânica, citando fatores como: formato de talhão, nivelamento de áreas e teor de umidade, bem como sincronismo de corte com o transporte e outros.

Conforme o manejo de reforma e de colheita adotados, bem como o tipo de solo e sua declividade, Furlani Neto (1994) e Soares et al. (1994), recomendam a redução do número, da altura e até a eliminação total dos terraços em áreas de colheita mecânica. Furlani Neto (1995), afirma que para otimizar os custos do corte mecânico trazendo uma resposta positiva em custo-beneficio no sistema mecanizado de colheita da cana, torna-se obrigatório à perfeita sistematização prévia do terreno, antecedendo a compra da colhedora, visando a diminuição nos custos e otimização do sistema. O mesmo autor faz referência ao método de sulcação S.A.D., para melhorar a colheita da cana-de-açúcar mostrando que os principais objetivos a serem alcançados são: corte simultâneo de 2 sulcos, implantação do tráfego controlado do talhão, diminuição da distância percorrida no talhão, aumento da longevidade e produtividade do canavial, melhora da eficácia do corte de base em sulcos duplos, viabilização das colhedoras e veículos atuais na frota motomecanizada, sem necessidade de novos investimentos, aumento dos desempenhos operacionais dessa frota e diminuição de custos operacionais. Este método necessita uma adequação das colhedoras e carretas/julietas para os espaçamentos, entre fileiras, de 1,4 0,80 e 1,20 $\times 0,80 \mathrm{~m}$.

Conforme Gandini et al. (1996), pelo fato de não existir paralelismo entre as curvas de nível, a sulcação que, normalmente, é iniciada nos terraços termina dentro do próprio talhão, ocasionando sulcos mortos. Com isto, as máquinas devem fazer mais manobras, reduzindo sua eficiência operacional e provocando maior compactação do solo. Estes autores realizaram um trabalho em que alteraram o traçado de carreadores, sulcação e conservação de solos de uma área destinada à colheita mecânica de cana crua, trabalho este denominado de "planejamento de sulcação". Como resultados reduziu-se em, $12,7 \%$ as horas com manobras de colhedoras, além da obtenção do ganho de $2,19 \%$ na área produtiva com a redução da área de carreadores.

Ruiz \& Orosco (1999) comentam, que a sistematização da área tem que dar solução ao aproveitamento integral do solo, assim como as necessidades de irrigação, drenagem e a mecanização da colheita. 
Magro (1999) afirma que, na Austrália, um item importante para a colheita da cana crua naquele país, é a adoção de pequenos camalhões (leira de terra na fileira da cana), permitindo a irrigação por sulco na entre-fileira da cana, facilitando a indicação para que os operadores dos equipamentos não transitem sobre as touceiras da cana, facilitando o corte de base da cana pelas colhedoras, bem como proporcionando menor perda na colheita.

Ruiz \& Orosco (1999) relatam que, em Cuba, o talhão é considerado um elemento básico onde se planejam, executam e controlam as atividades agronômicas da colheita. Mostram que o talhão, deve ter no mínimo 80 e, no máximo, 200 ha e, dentro dos limites de cada região devem apresentar uniformidade quanto a: relevo, solo, irrigação ou sequeiro, mecanização ou não, variedades e outras medidas agronômicas. Estes autores afirmam, ainda, que os comprimentos ideais das fileiras não devem ser inferiores a $300 \mathrm{~m}$ e não superiores a $500 \mathrm{~m}$; sendo que os carreadores longitudinais devem ser de $4,8 \mathrm{~m}$ e os transversais de $5 \mathrm{~m}$; tudo isto para proporcionar um aproveitamento racional das colhedoras e demais componentes que intervêm no processo.

\subsection{Comparativo de custos e desempenhos: colheita mecanizada $x$ colheita} manual

Freitas (1981) estimou, comparativamente, para a safra de 1980 , os custos da colheita de cana com corte manual e com cortadoras mecânicas acopladas a trator. 0 corte mecânico apresentou um custo $23 \%$ menor do que o manual.

Ripoli \& Mialhe (1982), comparando o custo do corte manual com carregamento mecânico versus a colheita com colhedoras, na safra 1981/82, em 5 usinas paulistas, apuraram 3 resultados em função da produção das colhedoras por safra. Se cada colhedora operasse 100 mil toneladas/safra de cana, a colheita mecanizada seria $4 \%$ mais cara que o corte manual com carregamento mecânico. Caso operasse 200 mil toneladas/safra, a colheita mecanizada já seria $19 \%$ mais barata e, se fosse 300 mil toneladas/safra, seria então, $28 \%$ mais barata.

Balbo (1992), efetuou um estudo de custos de colheita manual de cana queimada e colheita mecânica de cana crua e queimada na usina São Francisco (Sertãozinho - SP), comparando-se apenas o subsistema de corte: o mecânico, em cana queimada, foi $3 \%$ menos custoso que o manual também em cana queimada. No 
caso da cana crua, o corte mecânico foi $18 \%$ mais caro que o mecânico em cana queimada. Na comparação do subsistema de corte manual e carregamento mecânico com o subsistema de corte mecânico e sua infra-estrutura na cana queimada, o segundo ficou $22 \%$ mais barato que o primeiro e $33 \%$ menos custoso que o subsistema de corte mecânico e infra-estrutura para cana crua.

Bonine Júnior (1993), apresentou o tempo trabalhado de colhedoras na Usina Ester na safra 1992/93. De um total de 1.400 horas possíveis de operação, tanto na cana crua como na queimada na safra, houve 690 horas paradas $(49,3 \%)$, sendo, destes, $33 \%$ devido a reparos mecânicos, $29 \%$ por estar aguardando peças, $9 \%$ para movimentação das colhedoras e $7 \%$ para realização de revisões preventivas. Cada uma das duas colhedoras da empresa cortou, em média, 17,41 t. $\mathrm{h}^{-1}$ trabalhada (tanto crua, como queimada). Apropriando-se os custos diretos os resultados foram os seguintes: corte manual em cana queimada mais barato que o mecânico nas mesmas condições (US\$2,08. $\mathrm{t}^{-1}$ e US\$2,48. $\mathrm{t}^{-1}$, respectivamente); também na cana crua, o corte manual (US\$ 3,92.t. $\mathrm{t}^{-1}$ ) ficou mais barato que o corte mecânico (US\$ 5,46.t $\mathrm{t}^{-1}$ ).

Furlani et al. (1996) avaliando o desempenho de colhedoras Santal Amazón, na região de Ribeirão Preto, na safra 1993/94, encontraram capacidades efetivas de $57,78 \mathrm{t} \cdot \mathrm{h}^{-1}$ em cana crua e 66,79 t. $\mathrm{h}^{-1}$ em cana queimada. A qualidade tecnológica da matéria prima (brix do caldo, pol do caldo e da fibra), foram significativamente superiores para a cana crua.

Fernandes \& Irvine (1986) realizaram um estudo para medir a produtividade de cana em área de colheita mecanizada e em área de corte manual. Foram estudadas, em 5 ensaios, 3.300 toneladas de cana, entre os anos de 1983 e 1985 junto aos parâmetros: produtividade de cana $\left(t \cdot h^{-1}\right)$, açúcar teórico recuperável $\left(\mathbb{N} . t^{-1}\right)$ e a produtividade do açúcar (t.ha ${ }^{-1}$ ). Os resultados apontaram que não houve alteração de produtividade de cana em função do tipo de corte, mas sim da produtividade de açúcar, que foi maior no corte manual do que no mecanizado $\left(10,44\right.$ tha ${ }^{-1}$ e 10,11 tha $^{-1}$, respectivamente), principalmente devido ao maior teor de fibras na colheita mecanizada.

\subsection{Perdas e matéria-estranha}

A eficiência e a eficácia dos sistemas de colheita mecânica da cana-de-açúcar também, devem levar em consideração não só a quantidade de matéria-prima colhida, 
mas também a qualidade do trabalho desenvolvido pela máquina.

Perdas de matéria-prima deixadas no campo, perdas na matéria-prima que não é aproveitada pela industria como frações de rebolos, lascas, outros ou as denominadas de perdas invisíveis, bem como matérias estranhas vegetais e minerais, agregadas à matéria-prima, diminuindo sua qualidade, definem a eficácia da colheita mecânica.

Em Cuba, Betancourt (1967), utilizando dados de 15 usinas, analisou a presença de matéria estranha nos sistemas de colheita semimecanizada da cana de açúcar, mostrando que, a matéria-prima que chegava às usinas era constituida, em média, percentualmente: ponteiros $=30$; folhas e palhas $=42,83$; rebrotos $=9,21$; colmos secos=10,57 e terra=7,30; verificou, também, que a constituição média de matéria estranha era de $6,64 \%$ de ponteiros, $0,21 \%$ de rebrotos; $0,19 \%$ de colmos secos; $3,94 \%$ de palhas e folhas verdes e $0,19 \%$ de terra.

Fernandes \& Oliveira (1977), fizeram vários levantamentos no Estado de São Paulo, com relação às matérias estranhas vegetais e minerais nos sistemas de corte manual e carregamento em feixes (chamados de colheita manual), corte manual e carregamento mecânico (chamado de corte semimecânico) e colheita mecânica nas safras $1974 / 75$ e 1976/77. Na média, das 2 safras, a colheita manual apresentou $4,6 \%$ de matéria estranha, similar ao resultado do corte semimecânico. Contudo, a colheita mecânica apresentou $16,7 \%$ de matéria estranha, sendo que, mais de $90 \%$ em matéria estranha vegetal. Os autores atribuíram como prováveis causas do elevado teor de matéria estranha na colheita mecânica à ocorrência de chuvas, local de colheita e habilidade dos operadores.

Comparando o sistema de colheita da cana-de-açúcar de corte manual com canas amontoadas e corte mecanizado de canas inteiras, Furlani Neto (1984), verificou para o corte manual: 1,74 tha ${ }^{-1}$ de perdas de canas inteiras deixadas no solo; 1,02 tha $^{-1}$ de frações de colmos agregados ao palmito e 0,76 de tocos deixados no campo, decorrente da altura de corte basal, totalizando 4,52 tha ${ }^{-1}$ de perdas. No corte mecanizado o autor encontrou perdas de cana, nos tocos deixados na altura do corte basal de 1,48 tha ${ }^{-1}$ e 2,24 tha ${ }^{-1}$ de colmos deixados durante o carregamento, totalizando 3,72 t.ha $^{-1}$, representando $7,5 \%$ de perdas totais. Verificou, também, Índices de raizes de $0,2 \%$ e Índices de $2,39 \%$ e 1,36\% para matérias estranhas minerais e vegetais, respectivamente, tendo justificado estes índices pelo uso de 
rastelo durante o carregamento mecânico, a qualidade da matéria-prima, a queima realizada para o corte e a altura utilizada para o desponte.

Estudando a produtividade e a qualidade tecnológica da cana-de-açúcar para a colheita mecanizada e o corte manual em talhões comerciais de quatro usinas, Fernandes \& Irvine (1986) observaram, perdas totais de $14,3 \%$ para o corte manual e, $18,3 \%$ para o corte mecanizado, onde ainda verificaram o indice de $6,0 \%$ de folhas contidas na carga.

Herrera \& Linares (1986) estudando eficiência de limpeza e perdas com colhedora KTP-1, em canaviais sem queima prévia em Cuba, encontraram indices, em $\%$, de matéria-estranha, ponteiros e palhas de: 10,0; 7,9 e 2,0 respectivamente.

Peixoto \& Delgado (1988), realizando ensaios em 1985/86, utilizando cortes em eitos de 5 e 7 fileiras de cana de açúcar com lavras em esteira contínua e em feixes, verificaram para as safras de 1985, matéria estranha vegetal igual a 4,02\% e matéria estranha mineral de $1,43 \%$ e, em 1986, matéria estranha vegetal de 2,16\% e mineral de $0,61 \%$. Os autores concluiram que os teores de matéria estranha vegetal são mais afetados pela qualidade da lavoura e pela mão-de-obra empregada no corte; e os teores de matéria estranha mineral são mais afetados pelos sistemas de eitos formados pelo corte, tipos de lavras e pelo carregamento. Nestes mesmos ensaios os autores obtiveram como resultados médios durante o ano agrícola de 1985: 0,73 t.ha $^{-1}$ de tocos; 0,46 tha $^{-1}$ de frações de colmos e 1,28 tha ${ }^{-1}$ de colmos inteiros não carregados; e durante o ano agricola 1986: 0,80 tha ${ }^{-1}$ de tocos; 0,41 tha $^{-1}$ de frações de colmos e 0,76 t.ha $^{-1}$ de colmos inteiros não carregados. Os autores concluiram que as perdas totais foram consideradas altas e que poderiam ser menores com um treinamento adequado da mão-de-obra para o corte.

Furlani Neto et al. (1989), estudando comparativamente as variedades de cana de açúcar NA 5679 e SP 711406, colhidas mecanicamente em canaviais com queima prévia e cana crua, verificou que não houve diferenças significativas em termos de perdas de colheita para quantidades de colmos, pureza \% e pol \%. A porcentagem de fibra na matéria prima colhida sem queima foi $1,9 \%$ maior que a queimada. Para as perdas deixadas no solo após a colheita da cana crua (palhas, folhas verdes e ponteiros), encontraram uma variação de 7,50 a 11,88 t.ha $^{-1}$.

Na revisão bibliográfica que faz, Moraes (1992) relata um estudo feito na Flórida (EUA) com colhedoras de cana, em que as perdas invisiveis foram apuradas em $3,2 \%$ 
devido à desintegração de colmos e perda de caldo durante a colheita.

Na Austrália, Shaw \& Brotherson (1992), estudaram a adoção de técnicas e métodos de colheita mecanizada em cana crua, que reduzisse as perdas e os índices de matéria estranha estabelecidos de 2,96 a 4,42 tha ${ }^{-1}$. Os autores concluiram que não existe um ponto ótimo na relação entre perdas de cana e matéria estranha e que estes valores reduzem as vantagens financeiras em se adotar a colheita da cana crua em relação à queimada.

Estudando as perdas na colheita da cana de açúcar, Rosa et al. (1993) verificaram, que para as variedades estudadas as perdas totais obtidas, em valores médios na safra $1989 / 90$ foram de 1,79 a 3,78 tha-1 e na safra de 1990/91 foram de 1,56 a 2,19 t.ha $^{-1}$.

Mutton et al. (1992), analisando o sistema de pagamento pela qualidade das caracteristicas tecnológicas da cana de açúcar, afirmam que para valores elevados de matéria estranha mineral, a partir de $4 \%$, ocorre à depreciação da qualidade da matéria prima a ser processada bem como sua valorização final.

Furlani et al. (1996) quantificaram as perdas visiveis com colhedoras Santal Amazón na região de Ribeirão Preto na safra 1993/94 variando entre 2,13\% e 3,56\% para cana crua e entre $1,08 \%$ e $1,98 \%$ na cana queimada; relatando também ter verificado Indice de Ponteiros de 9,0\%.

Lima (1994) relata, que obteve como valores médios de perdas totais entre a cana crua e a queimada para a safra $1993 / 94$ de 3,86 e 3,54 tha ${ }^{-1}$ respectivamente. $O$ autor obteve com colhedoras Engeagro E-6000 percentuais de rebolos inteiros, rebolos e suas frações, rebolos na soqueira de 14,$12 ; 53,59 ; 21,98$ respectivamente e com a Engeagro E-8000 percentuais de 31,$6 ; 45,85 ; 17,35$ respectivamente.

Furlani Neto et al. (1996), observando dados de usinas de açúcar, verificaram que a partir do desenvolvimento tecnológico e da sistematização dos talhões, as atuais colhedoras de cana-de-açúcar, conseguem uma capacidade efetiva em média, de 60 t/h com perdas no campo variando de 3 a 6 t.ha $^{-1}$ e, indice de matéria estranha de 3 a $8 \%$. Moraes \& Neves (1997), avaliando o desempenho de 3 modelos de colhedoras em 2 variedades de cana-de-açúcar sem queima prévia, acusaram perdas ao redor de 4\%, impurezas vegetais em torno de $9,9 \%$ e impurezas minerais de, aproximadamente, 0,3\%. Em outro estudo, estes autores utilizando uma colhedora Austoft-7000, realizaram, sob condições controladas, ensaios para verificação de perdas invisiveis, a 
partir da perda de peso da cana que ocorre durante o seu processamento pelo mecanismo interno pela colhedora, em três variedades de cana-de-açúcar. Obtiveram assim as perdas invisiveis da ordem de 2,1 a $5,4 \%$, mostrando que as perdas invisíveis são função em primeiro lugar das variedades e depois da ação dos mecanismos das colhedoras, tais como corte de base, facões picadores e do ventilador do extrator primário. Utilizando quatro tipos diferentes de colhedoras autopropelidas e duas variedades de cana-de-açúcar, Moraes \& Neves (1997) verificaram que houve um aumento das perdas de pedaços de cana com o aumento da rotação do extrator primário, bem como a diminuição da incidência de impurezas na carga. Os autores concluíram ser importante o planejamento da regulagem da rotação do extrator primário diante das diferentes condições encontradas na colheita, como exigir maior rotação do extrator para minimizar a incidência de impurezas e aumentar a densidade da carga em variedades com massa foliar alta e estágios inicial de corte, assim como canaviais com massa vegetal pequena poderão ser colhidos com regulagens distintas da condição anterior.

Nunes Júnior \& Pinto (1999), mostram através de pesquisa realizada através de questionários aplicados a 149 empresas com moagem anuais superior a 500.000 toneladas de cana-de-açúcar, as expectativas destas empresas com colheita mecanizada para cana queimada e crua, no tocante a matérias estranhas vegetais e minerais. Os valores obtidos na cana colhida mecanicamente no centro sul do Brasil na safra $1998 / 99$ foi de $6,12 \%$ na cana queimada e $6,60 \%$ na cana crua; e a previsão para a safra $1999 / 2000$ é de $4,93 \%$ na cana queimada e $5,79 \%$ na cana crua. Da mesma maneira para matérias estranhas minerais, na safra $1998 / 99$ foi de $1,07 \%$ na cana queimada e 1,10\% na cana crua; e a previsão para a safra 1999/2000 é de 1,19\% na cana queimada e $0,93 \%$ na cana crua.

\subsection{Desempenho Operacional}

Ripoli (1996), diz que a análise do desempenho operacional de cortadoras e colhedoras de cana-de-açúcar, não se deve limitar apenas a sua capacidade efetiva, em termos de $\mathrm{kg} \cdot \mathrm{h}^{-1}$ ou t.dia ${ }^{-1}$. Devendo-se levar em conta também, a qualidade da matéria-prima, bem como as suas perdas $e$, sua capacidade operacional. $O$ autor descreve desempenho operacional de colhedoras de cana-de-açúcar como sendo o 
conjunto de atributos que caracterizam o grau de habilitação da máquina para execução da operação de colheita, sob determinadas condições operacionais.

Mialhe \& Carraro Neto (1993) mostram que, os referidos graus de habilitação, são reunidos nos grupos: capacidade de colheita, qualidade do processamento do produto, funcionalidade mecânica e ergonomia e segurança.

Resultados de desempenho médio de colhedoras Brastoft 42 A-7000 e 55 A7700 , em 29 usinas produtoras de açúcar e álcool, no Brasil, referentes às safras 96/97 e 97/98, foram apresentados no agrishow 98, como, Boletim técnico de dados da colhedora brastoft (1998), e mostram valores no quadro 1.

Quadro 1. Valores médios de Desempenho Operacional em 29 usinas produtoras de açuicar e álcool, referentes às safras 96/97 e 97/98.

\begin{tabular}{|c|c|c|}
\hline Parâmetro & Safras $96 / 97$ & Safras $97 / 98$ \\
\hline $\begin{array}{l}\text { Horas de trabalho por dia } \\
\text { Horas de trabalho na safra } \\
\text { Cana colhida }\left(t . h^{-1}\right) \\
\text { Consumo de óleo combustivel }\left(1 . h^{-1}-1 . t^{-1}\right) \\
\text { Consumo de óleo hidráulico }\left(1 . h^{-1}-1 . t^{-1}\right) \\
\left.\text { Custo total da colhedora (US\$. } t^{-1}\right) \\
\end{array}$ & $\begin{array}{c}1.959 \\
33,8 \\
35,0-1,08 \\
0,53-0,017 \\
1,11 \\
\end{array}$ & $\begin{array}{c}11,7 \\
2.310 \\
32,2 \\
35,1-1,12 \\
0,46-0,019 \\
1,21 \\
\end{array}$ \\
\hline
\end{tabular}

Fonte: Brastoft (1998).

Através de um levantamento em vários produtores brasileiros de cana-deaçúcar, Lima (1998) observou o comportamento, de várias colhedoras operando em condição de cana crua conforme o quadro 2.

Quadro 2. Parâmetros de Desempenho de colhedoras de cana-de-açúcar.

\begin{tabular}{ccccc}
\hline Parâmetros & Amazón & Brastoft & Cameco & Claas \\
\hline t.safra $^{-1}$ & $37.533-80.739$ & $49.035-121.182$ & $91.230-121.268$ & $82.268-95.819$ \\
t.dia $^{-1}$ & $205-441$ & $242-645$ & $414-583$ & $388-457$ \\
l.t $^{-1}$ & $0,71-1,54$ & $0,81-1,56$ & $0,81-1,08$ & $0,70-1,04$ \\
${\text { US } \$ . \mathrm{t}^{-1}}^{-1}$ & $0,94-2,02$ & $0,90-1,69$ & $0,97-1,23$ & $1,13-1,36$ \\
\hline
\end{tabular}

Fonte: Adaptado de Lima (1998).

Em relatório gerencial (Interno), a Usina Guarani, mostrou dados de desempenho da colheita mecanizada na Safra 95/96, com Claas CC2000, conforme quadro 3. 
Quadro 3. Parâmetros de Desempenho de colhedora CC 2000, na Usina Guarani.

\begin{tabular}{lc}
\multicolumn{1}{c}{ Parâmetros } & Valores \\
\hline Dias de safra (colheita mecanizada) & 152 \\
Total de horas trabalhadas & 14.926 \\
Produtividade do canavial $\left(\mathrm{t} . \mathrm{ha}^{-1}\right.$ ) & 71,6 \\
Cana colhida (t) & 467.966 \\
Capacidade operacional média $\left(\mathrm{t} . \mathrm{h}^{-1}\right)$ & 31,35 \\
Eficiência global média (\%) & 42,26 \\
Consumo total de combustível $(\mathrm{l})$ & 284.659 \\
Consumo médio de combustivel $\left(\mathrm{I} . \mathrm{h}^{-1}\right)$ & 19,07 \\
Consumo médio de combustível $\left(\mathrm{l} . \mathrm{t}^{-1}\right)$ & 0,61 \\
Perdas médias (t.ha-1) & 4,69 \\
Perdas médias $(\%)$ & 6,56
\end{tabular}

Fonte: Adaptado de relatório interno da Usina Guarani (1997).

O quadro 4, adaptado de Ripoli (1996), apresenta alguns resultados encontrados na bibliografia referente à capacidade efetiva $\left(t . h^{-1}\right)$, qualidade da matériaprima (\%) e, as perdas (t.ha ${ }^{-1}$ ou \%) na operação de corte e/ou colheita mecanizada em cana queimada.

Quadro 4. Resultados médios de Capacidade Efetiva-CE $\left(\mathrm{t} . \mathrm{h}^{-1}\right)$, de Índices de Matéria Estranha Vegetal-IV (\%), Mineral-IM (\%), Não Identificada-II (\%), Total-IT (\%), e Perdas de matéria-prima (t. $h^{-1}$ ou \%) para cortadoras e colhedoras de cana-de-açúcar.

\begin{tabular}{|c|c|c|c|c|c|c|c|c|}
\hline Autores & $\begin{array}{l}\text { Tipos de } \\
\text { máquinas }\end{array}$ & CE & IV & IM & II & IT & \multicolumn{2}{|c|}{ Perdas } \\
\hline & & t. $h^{-1}$ & 4 & & $\%-$ & $\Longrightarrow$ & $\operatorname{tha}^{-1}$ & $\%$ \\
\hline Bitancourt (1967) & Colhedora & - & 3,93 & 0,31 & - & 4,2 & - & - \\
\hline Ripoli et al. (1975) & $\begin{array}{l}\text { Cortadora } \\
\text { Cortadora - }\end{array}$ & 30,6 & - & - & - & - & - & - \\
\hline & amontoadora & 21,9 & - & - & - & - & - & - \\
\hline & Colhedora & 14,7 & - & - & - & - & - & - \\
\hline Tambosco et al. (1977) & Colhedora & - & 10,0 & 0,20 & 0,30 & 10,5 & - & - \\
\hline Furlani Neto et al. (1977) & Colhedora & - & - & - & - & - & 3,6 & - \\
\hline Furlani Neto et al. (1978) & Colhedora & - & $\begin{array}{l}3,2 \\
4,5\end{array}$ & $\begin{array}{c}0,1 \\
0,26\end{array}$ & $\begin{array}{l}0,5 \\
1,0\end{array}$ & $\begin{array}{l}4,2 \\
5,8\end{array}$ & - & - \\
\hline Freitas et al. (1979) & $\begin{array}{l}\text { Cortadora - } \\
\text { amontoadora }\end{array}$ & 25,2 & - & - & - & - & 3,33 & - \\
\hline Ripoli \& Mialhe (1980) & Colhedora & 39,8 & 7,28 & 0,83 & 0,74 & 9,1 & - & 16 \\
\hline Furlani Neto et al. (1996) & Colhedora & 59,1 & 5,59 & 0,46 & - & 6,0 & - & - \\
\hline Furlani Neto et al. (1996) & Colhedora & 68,9 & 5,30 & 0,67 & - & 5,9 & - & - \\
\hline
\end{tabular}

Fonte: Adaptado de Ripoli (1996). 
Romero et al. (1997) realizaram na Argentina, levantamento de desempenho operacional em 29 colhedoras de cana-de-açúcar, em canaviais sem queima prévia, e obtiveram os seguintes resultados: colheita de 74000 a 112000 t.safra ${ }^{-1}, 325$ a 628 t.dia ${ }^{-1}$, consumo de combustivel de 0,9 a $1,6 \mathrm{I} \cdot \mathrm{t}^{-1}$ de cana colhida e, "trash" de 5,5 a 6,5 $\%$.

Furlani neto et al. (1996), avaliando o desempenho operacional da colhedora Santal-Amazón, na Usina Santa Lídia - SP, obtiveram: capacidade efetiva de 57,78 t. $h^{-1}$ e 66,79 t. $h^{-1}$ com velocidades de 4,65 e 5,50 km. $\mathrm{h}^{-1}$, em canaviais sem e com queima prévia, respectivamente. Analisando máquinas reguladas para cana crua na Usina São Francisco - SP, Soares et al. (1994) verificaram: capacidade efetiva de 60,4 t. $h^{-1}$. Mialhe \& Carraro Neto (1993) ensaiando colhedora Claas CC-2000, em colheita de cana crua, encontraram os valores de capacidade efetiva bruta e liquida, como mostra o quadro 5 .

Quadro 5. Resultados de Desempenho Operacional em dois ensaios com CC-2000, realizados em cana crua.

\begin{tabular}{lcc}
\hline & \multicolumn{2}{c}{ Ensaio a velocidades de } \\
\cline { 2 - 3 } & $3,67 \mathrm{~km} \cdot \mathrm{h}^{-1}$ & $4,04 \mathrm{~km} \cdot \mathrm{h}^{-1}$ \\
\hline Capacidade efetiva bruta $\left(\mathrm{t} . \mathrm{h}^{-1}\right)$ & 83,83 & 75,64 \\
Capacidade efetiva liquida $\left(\mathrm{t} . \mathrm{h}^{-1}\right)$ & 73,47 & Não determinado \\
Eficácia de manipulação (\%) & 96,78 & 96,86 \\
Perda total no campo bruta (\%) & 3,22 & 4,14 \\
Matéria estranha total $\left(\mathrm{t} . \mathrm{h}^{-1}\right) /(\%)$ & 14,09 a 13,35 & Não determinado
\end{tabular}

Fonte: Adaptado de Mialhe \& Carraro Neto (1993). 
Realizando ensaios de desempenho operacional em Tucuman, na Argentina, com colhedoras Claas Gladiador e Claas CC 2000, em canaviais sem queima prévia, Romero et al. (1993) observaram, que os canaviais estudados variavam de 60 a 140 t.ha $^{-1}$ de produtividade $e$ as máquinas apresentaram os resultados mostrados no quadro 6.

Quadro 6. Desempenho Operacional das Colhedoras, Gladiator e CC2000.

\begin{tabular}{ccccccc}
$\begin{array}{c}\text { Modelos } \\
\text { De } \\
\text { Colhedoras }\end{array}$ & Variedades & $\begin{array}{c}\text { Velocidades } \\
\text { de } \\
\text { Trabalho } \\
\left(\mathrm{km}^{-1} \mathrm{~h}^{-1}\right)\end{array}$ & $\begin{array}{c}\text { Capacidades } \\
\text { Efetivas } \\
\left(\mathrm{t} . \mathrm{h}^{-1}\right)\end{array}$ & $\begin{array}{c}\text { Perdas da } \\
\text { Matéria } \\
\text { Prima } \\
(\%)\end{array}$ & $\begin{array}{c}\text { "Trash" } \\
(\%)\end{array}$ & $\begin{array}{c}\text { Eficiências } \\
\text { de } \\
\text { limpeza } \\
(\%)\end{array}$ \\
\hline \multirow{2}{*}{$\begin{array}{c}\text { Class } \\
\text { Gladiator }\end{array}$} & CP65577 & 4,9 & 40 & 4,7 & 10 & 64 \\
& TU66727 & 3,6 & 40 & 2,8 & 13 & 62 \\
& CP65357 & 5,6 & 56 & 5,7 & 12 & 60 \\
\hline Claas & CP65357 & 5,8 & 58 & 6,6 & 7,8 & 56 \\
CC 2000 & TU7742 & 3,5 & 71 & 7,2 & 5,3 & 71 \\
\hline
\end{tabular}

Fonte: Adaptado de Romero et al., (1993).

Os autores afirmam que para se conseguir resultado melhor, seria necessário uma melhor sistematização do plantio e, maior treinamento dos operadores das colhedoras.

Ripoli \& Mialhe (1982) em estudo efetuado para determinação de custo de colheita da cana-de-açúcar queimada no Estado de São Paulo, na safra 81/82, verificaram uma média na capacidade operacional de $35,52 \mathrm{t} . \mathrm{h}^{-1}$, em 50 colhedoras combinadas (13 Dedini Toft, 26 Santal-115 e, 11 Santal rotor). Ripoli \& Alves Berto (1981) avaliando desempenho de colhedoras na região de Campos - RJ, utilizando colhedoras Santal-115, Dedini Toft R-300 e, MF-201, obtiveram uma capacidade operacional média para as máquinas de $32,84 \mathrm{t} \cdot \mathrm{h}^{-1} \mathrm{em}$ cana queimada. 


\subsection{Desempenho Econômico}

O desempenho econômico de uma máquina é definido por Ripoli \& Mialhe (1982), como sendo a associação dos dados de custo hora, formados pela estimativa de gastos de propriedade e gastos operacionais (orçamentação de custos), com os dados de desempenho operacional.

Noronha et al. (1991), recomenda a abordagem da orçamentação de custos pelo chamado "método do custo anualizado equivalente - CAE", desenvolvido a partir do conceito de anuidade equivalente, para o cálculo do custo anual da maquinaria.

Mialhe \& Carraro Neto (1993), dizem que um projeto de orçamentação de custos deve permitir uma modelagem do cenário de custos, possibilitando que sejam conhecidos antecipadamente, os limites de solicitação da máquina, ou seja, limites a partir dos quais inviabiliza-se, economicamente, sua operação.

Esse método CAE, de estruturação de custos, conforme relatado por Noronha et al. (1991), mostra que todos os fatores são variáveis uma vez que é projetada para toda a vida da máquina, desde sua aquisição até o momento do descarte à terceiros ou sucateamento. Os autores descrevem o método CAE, para utilização especifica na compra de novas máquinas ou a determinação do melhor momento para reposição de unidades em final de vida útil.

Balastreire (1995) mostra, vários métodos utilizados para determinação do ponto de renovação ou substituição de uma máquina agrícola. $O$ autor cita, entre outros métodos, o do custo mínimo anual equivalente (CAE), e conclui que em todos os métodos de cálculo de custo operacional, existe a necessidade de se controlar os diversos componentes de custos dos usos das máquinas.

Peterson \& Milligan (1976), utilizaram o conceito de vida econômica para otimização da aquisição e renovação de frotas.

Audsley et al. (1978), utilizaram métodos para o cálculo do custo anual de maquinaria, utilizando fluxo de caixa atualizados através do CAE, para determinação do ponto de substituição de máquinas.

Mialhe \& Carraro Neto (1993), descrevem o projeto de custo anualizado equivalente (CAE), como um critério que se baseia numa estrutura de fluxo de caixa que espelhe o investimento inicial de uma colhedora de cana-de-açúcar, todas as despesas previstas durante sua permanência empresa e o seu valor de revenda ou sucateamento, depois de cumprido um razoável período de vida útil. Os autores 
mostram que os itens levados em consideração na construção do fluxo de caixa são os seguintes: valor inicial e valor residual após um tempo de vida útil, juros, seguro, alojamento \& administração, combustivel, lubrificantes, filtros, comboios de manutenção \& abastecimento, peças de reposição \& serviços mecânicos e mão de obra do operador.

O valor inicial e o valor residual são utilizados para efeito de depreciação da colhedora que, segundo Hoffmann et al. (1987) trata-se, do montante necessário para substituir o bem de capital quando se torna inútil pelo desgaste físico ou quando perde o valor com o passar dos anos devido às inovações tecnológicas.

O cálculo da depreciação, é descrito por Lins (1975), que considera simplesmente como desvalorização do bem, reduzindo-se gradualmente seu preço nos inventários sucessivos durante sua utilização.

Todos os métodos, inclusive o utilizado neste trabalho, utilizam um período de vida esperado para cada tipo de máquina como estimativa da depreciação, conforme descrito por Moreira \& Menezes (1973), não se levando em consideração a intensidade de uso da colhedora. Portanto, os métodos existentes para o cálculo da depreciação são aproximações da depreciação real.

Hoffmann et al. (1987), justificam a importância dos juros sobre o capital, supondo que o produtor rural financia todo o capital circulante da empresa pagando juros e, mesmo que isto não aconteça, deve-se atribuir juros ao montante, que poderia ter sido aplicado no mercado financeiro obtendo-se estes juros como ganho efetivo.

O seguro, deve ser considerado conforme descrito por Moreira \& Menezes (1973), pois representa o custo para garantir o bem, em caso de incêndios, roubos, acidentes e outros sinistros.

Alojamento e administração, são os custos desembolsados para abrigar e administrar o bem durante sua vida útil, mesmo com a duração da vida útil do alojamento sendo maior que a vida útil do bem, conforme relatado por Moreira \& Menezes (1973).

O custo do consumo de combustível conforme recomendado por Moreira \& Menezes (1973) deveria ser levantado através do consumo de combustivel com base em dados reais realizando a operação específica, não sendo isso possivel, recomendam a obtenção destes dados segundo a percentagem de carga no motor com relação a sua máxima potência. 
Noronha et al. (1991) mostram, que o combustível representa de 20 a $50 \%$ do custo hora de um trator agrícola.

Conforme relatado por Mialhe \& Carraro Neto (1993), os dispêndios com lubrificantes envolvem os que necessitam de troca periódica e/ou consumo, como óleo do sistema hidráulico e do cárter do motor e de eventuais vazamentos, como trocas de mangueiras rompidas, por exemplo. A estimativa do consumo adicional de óleos é extremamente dificil quando não se dispões de registros de campo da máquina e, conforme Braunbek ${ }^{2}$, citado por Mialhe et al. (1993) através de registros nas usinas que utilizam a colhedora DM-6000, apresentam um consumo médio de 1,4 litros por hora. O custo atribuído ao comboio de manutenção e abastecimento, trata-se do dispêndio associado ao uso deste serviço, sendo expresso como produto do custo hora do comboio pelo tempo consumido no abastecimento e manutenção.

Os custos das peças de reposição e serviços mecânicos, são dispêndios, associados principalmente com os desgastes de componentes devido ao uso da máquina, sendo que o fator durabilidade, constitui o principal elemento determinante da época de ocorrência destes dispêndios e, com dispêndios de peças oriundas de manutenção preventiva (periódica), como filtros, correias e outros. Este fator, pode ser quantificado de duas maneiras, a primeira por critério de previsão através de dados fornecidos pelo manual de manutenção da máquina fornecida pelo fabricante ou, utilizando informações da área de manutenção de máquinas da usina e a segunda, por critério de estimativa através dos documentos de controle dos serviços mecânicos realizados na máquina, utilizando-se um critério estatístico.

O custo da mão-de-obra do operador da colhedora, conforme descrito por Moreira \& Menezes (1973), admite que a mão-de-obra é dedicada ao trabalho da máquina e, neste caso, o total do salário acrescido dos encargos sociais é dividido pelo número total esperado de horas de trabalho.

Ripoli \& Mialhe (1982) mostram valores referentes a custos operacionais de colhedoras de cana de 3,15 US $\$ . t^{-1}$ para 100.000 t de cana; 2,20 e 1,88 US $\$ . t^{-1}$ para 200.000 e 300.000 t de cana respectivamente.

Foi apresentado no agrishow 98 como, Boletim técnico de dados da colhedora Brastoft (1998), valores oriundos da média de 26 usinas de açúcar e álcool com 85

\footnotetext{
2Braunbek, O. Citado por Mialhe \& Carraro Neto (1993), Avaliação e análise de desempenho de colhedora de cana-de-açúcar.
} 
máquinas mostrando que a média da participação em porcentagem, do componente do custo hora de uma colhedora de cana como sendo : 39,3 relativo a depreciação; 23,6 ao combustivel; 1,8 ao lubrificante; 27,2 a manutenção e 8,1 a mão de obra do operador da máquina.

Kronka \& Monteiro (1999) apresentando dados da safra 98/99 na Usina Iturama, mostram um custo operacional médio para a colhedora de cana-de-açúcar, modelo Brastoft A-7700 em cana crua de 2,09 US\$.t $\mathrm{t}^{-1}$ e para colhedora DM 6000 em cana queimada de 1,12 US $\$ . \mathrm{t}^{-1}$. 


\section{MATERIAL E MÉTODOS}

\subsection{Material}

Os estudos de campo foram realizados na Usina Dabarra, localizada no municipio de Barra Bonita, Estado de São Paulo; entre os dias 7 e 17 de julho de 1998 na fazenda Pasto Velho, na área identificada como talhão 9 , zona 1258 , cujas coordenadas geográficas são $22^{\circ} 35^{\prime} 24^{\prime \prime}$ de Latitude $S, 48^{\circ} 38^{\prime} 09^{\prime \prime}$ de Longitude W, e $546 \mathrm{~m}$ de Altitude.

O material utilizado neste trabalho, abrangeu: um espécime de máquina colhedora para cana-de-açúcar, adequada a operar em canaviais sem queima prévia, bem como veículos de transbordo e transporte. A caracterização das condições de campo, conforme apresentado no sub-tópico $3.1 .2 \mathrm{e}$, equipamentos para determinações quali-quantitativos, conforme apresentado no item 3.1.4.

Para a operação da colhedora, foi utilizado operador treinado e experiente no modelo especifico, a fim de diminuir possíveis influências no manejo da máquina. Foi utilizada ainda, a estrutura da Usina Dabarra para o corte, transporte, análises de perdas e análises tecnológicas da cana.

\subsubsection{Colhedora}

\subsubsection{Características técnicas}

Tipo: $\quad$ Combinada

Origem: Importada

Ano de fabricação: 1996

Valor de aquisição: US $\$ 305.000,00$ 
Cortador basal: Dois discos, uma linha de $1,5 \mathrm{~m}$ ou duas linhas de $1,0 \mathrm{~m}$; acionamento hidráulico; regulagem de altura hidráulica; acionamento reversivel.

Despontador: Dois discos com taliscas metálicas, dois discos de corte, sem-fim de descarga lateral, acionamento hidráulico, regulagem hidráulica de altura.

Picador de colmos: Tambor rotativo com duas lâminas a $180^{\circ}(1400 \mathrm{~mm})$; facas encravadas de troca rápida; acionamento reversivel.

Sistema de limpeza: limpeza de cana em quatro estágios, contendo dois ventiladores centrifugos, um principal e um auxiliar com duas saídas reguláveis hidraulicamente, descarga pela capota traseira, exaustor na saída do elevador de descarga com acionamento hidráulico.

Transmissão: $\quad$ hidrostática com caixa de câmbio de três velocidades.

Freios: Motor hidrostático na caixa de câmbio; freios de pé independentes com acionamento hidráulico; freio de acionamento mecânico. Capacidades: Depósito de combustivel para 600 litros; depósito de óleo para 200 litros, duas baterias $12 \mathrm{v}$ de $110 \mathrm{Ah}$, com sistema de arranque do motor de $24 \mathrm{v}$.

Árvore e Rodados: Árvore dianteira com pneus 24.5- R32 16PR; eixo traseiro com direção hidrostática e pneus $14.5 / 75-20$.

Massa total: $\quad 14.560 \mathrm{~kg}$.

Motor: Mercedes Benz V8 OM 442, 213 kW (290 cv) 


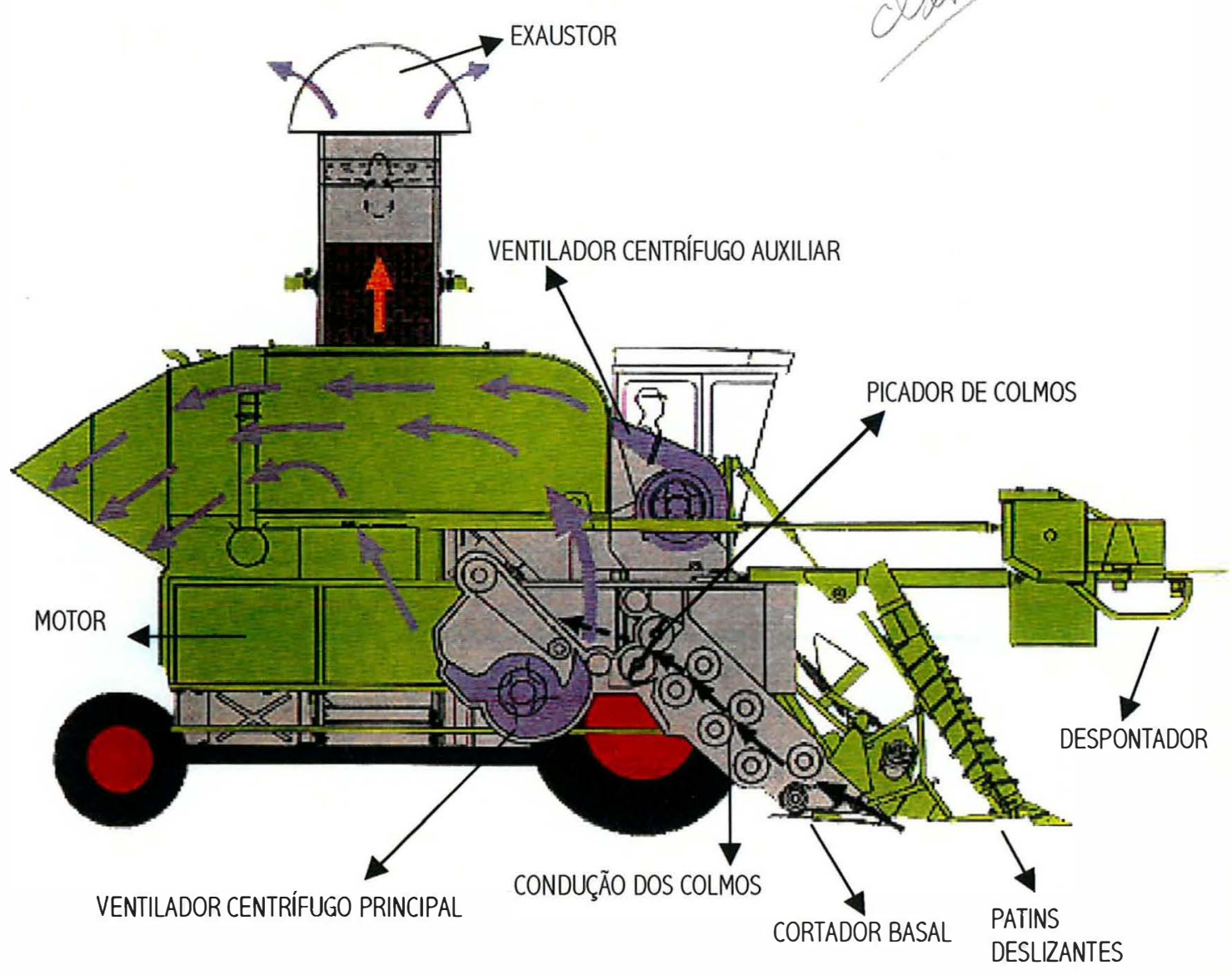

Figura 2. Desenho esquemático do espécime estudado.

3.1.1.2 Descrição do funcionamento básico da colhedora

A colhedora avaliada neste trabalho, apresenta as seguintes etapas de funcionamento:

a) Elevação e posicionamento das canas tombadas e acamadas:

A colhedora, ao deslocar-se sobre a linha da cana, entrando em contato com camas deitadas ou acamadas, faz seu levantamento e posicionamento direcionado ao interior da máquina, através de cones espiralados dispostos lateralmente à 
linha da cana. Tais cones, podem ser regulados, hidraulicamente, no sentido vertical e, apoiam-se no solo por patins deslizantes, acompanhando o contorno suave do terreno. A máquina permite uma regulagem hidráulica de até $1,90 \mathrm{~m}$ de largura para recolha da cana.

b) Desponte:

Os cortes das partes superiores da cana (ponteiros), ocorrem através de facas de aperto rápido em rotores acionados hidraulicamente e, existe ainda, um tambor com rosca sem fim, posicionado perpendicularmente às facas de corte, que faz o descarte rápido dos ponteiros da cana, lateralmente, à máquina. $O$ despontador pode ser posicionado, hidraulicamente, no sentido vertical, permitindo 0 ajuste a diversas alturas de ponteiros das canas.

c) Corte basal

O Corte de base, é realizado através de 6 facas dispostas radialmente através de um sistema de troca rápida, em dois discos rotativos providos de um sistema de interrupção automática, por embreagens, com acionamento e regulagem hidráulica de altura. O sistema possui, ainda, mecanismos de acionamento reversivel.

d) Picador dos colmos

Os colmos são picados através de dois tambores rotativos com duas lâminas cada um, de troca rápida, a $180^{\circ}$ (1400 mm), com acionamento mecânico, por correntes, e sistema de embreagem para interrupção automática em caso de embuchamento. Os tambores podem ser equipados com duas ou três fileiras de facas, permitindo assim, tamanhos de rebolos de 300 e $200 \mathrm{~mm}$ de comprimento, respectivamente. Estes tambores encontram-se localizados, ao fim do curso de elevação dos colmos ao interior da colhedora pelas correntes de roletes com taliscas. 
e) Condução dos colmos

A condução de colmos dentro da máquina, se dá na elevação dos colmos para alimentação e na elevação de descarga. A elevação dos colmos para alimentação ocorre através de correntes com roletes, e taliscas, acionadas hidraulicamente, elevando os colmos inteiros até os rolos picadores. A esteira transportadora possui fundo perfurado, a fim de reduzir a quantidade de matéria estranha mineral, eventualmente contida na matéria-prima colhida. No caso da elevação dos colmos para a descarga, o acionamento é hidráulico, com um dispositivo de parada instantânea de descarga.

f) Sistema de limpeza

A limpeza de matéria-prima ocorre, primeiramente por gravidade, através de orificios existentes nos elevadores. Remanescentes da matéria estranha, ainda contidas nos rebolos, são aspiradas por um exaustor de acionamento hidráulico, na saída do elevador de descarga, bem como por mais dois ventiladores tipo centrifugo com acionamento hidráulico, eliminando o palhiço, para fora pela parte traseira da colhedora.

\subsubsection{Caracterização das condições de campo}

a) Cultura: A variedade da cana-de-açúcar utilizada foi a RB 835089 , em canavial de cana-soca de $3^{\circ}$ corte, com 12 meses de idade, sem queima de pré-colheita.

b) Solo: Classificado pela Usina Dabarra, como Latosolo roxo.

\subsubsection{Caracterização dos veículos de transporte}

Foram utilizadas carretas de capacidade líquida de carga de 8 te, veículos de transbordo para receber a matéria-prima colhida e leva-la até 0 carreador e descarrega-la em caminhões tipo "treminhões", a fim de ser transportada para a industria onde ocorreram as determinações ponderais e tecnológicas. 


\subsubsection{Equipamentos para determinações de campo}

Foram utilizados os seguintes equipamentos para as determinações ponderais e dimensionais :

a) Célula de carga, com capacidade máxima para $500 \mathrm{kgf}(4905 \mathrm{~N})$ e acurácia de mais ou menos $0,5 \mathrm{kgf}(4,9 \mathrm{~N})$, com mostrador digital micro processado de 5 dígitos e saida RS-232. O conjunto, célula-mostrador, teve sua curva levantada através de pesos padrões ao longo de sua escala, onde se constatou uma curva linear, que foi corrigida por um fator de correção via programação do microprocessador do mostrador.

b) Duas trenas de 50 metros, régua com $50 \mathrm{~cm}$ de comprimento e menor leitura de $0,5 \mathrm{~cm}$, rolo de barbante, triângulo retângulo padrão, 2 cronômetros $1 / 100 \mathrm{~s}, 50$ latas de alumínio com tampa para amostras de solo, 4 tambores metálicos de 100 litros, 3 lonas plásticas de $3 \times 3 \mathrm{~m}, 3$ rolos de fita crepe, 100 etiquetas e barbantes, 30 sacos plásticos transparentes, 1 martelo, 4 pincéis atômicos.

\subsubsection{Equipamento para determinação do consumo de combustivel}

Medidor de vazão tipo velocimétrico de turbina axial da Caterpillar Fuel Flow Monitor System, modelo 1U-5430, com intervalo de acurácia de 11,4-266 $1 . h^{-1}$ e acurácia de leitura de mais ou menos $0,5 \%$. Foi realizada a avaliação de precisão do medidor de vazão onde se constatou, ótima precisão nas mensurações do mesmo.

Esta avaliação foi feita no laboratório de máquinas agrícolas da ESALQ, onde o medidor foi acoplado a um sistema de injeção de combustivel, com bomba injetora acionada por motor elétrico de rotação variável. A coleta do combustível injetado pelos bicos foi feita por mangueiras de plástico transparente e medidos por um volume padrão através de uma bureta de vidro.

A montagem da bancada, para calibração do medidor de vazão é mostrada na figura 3. 


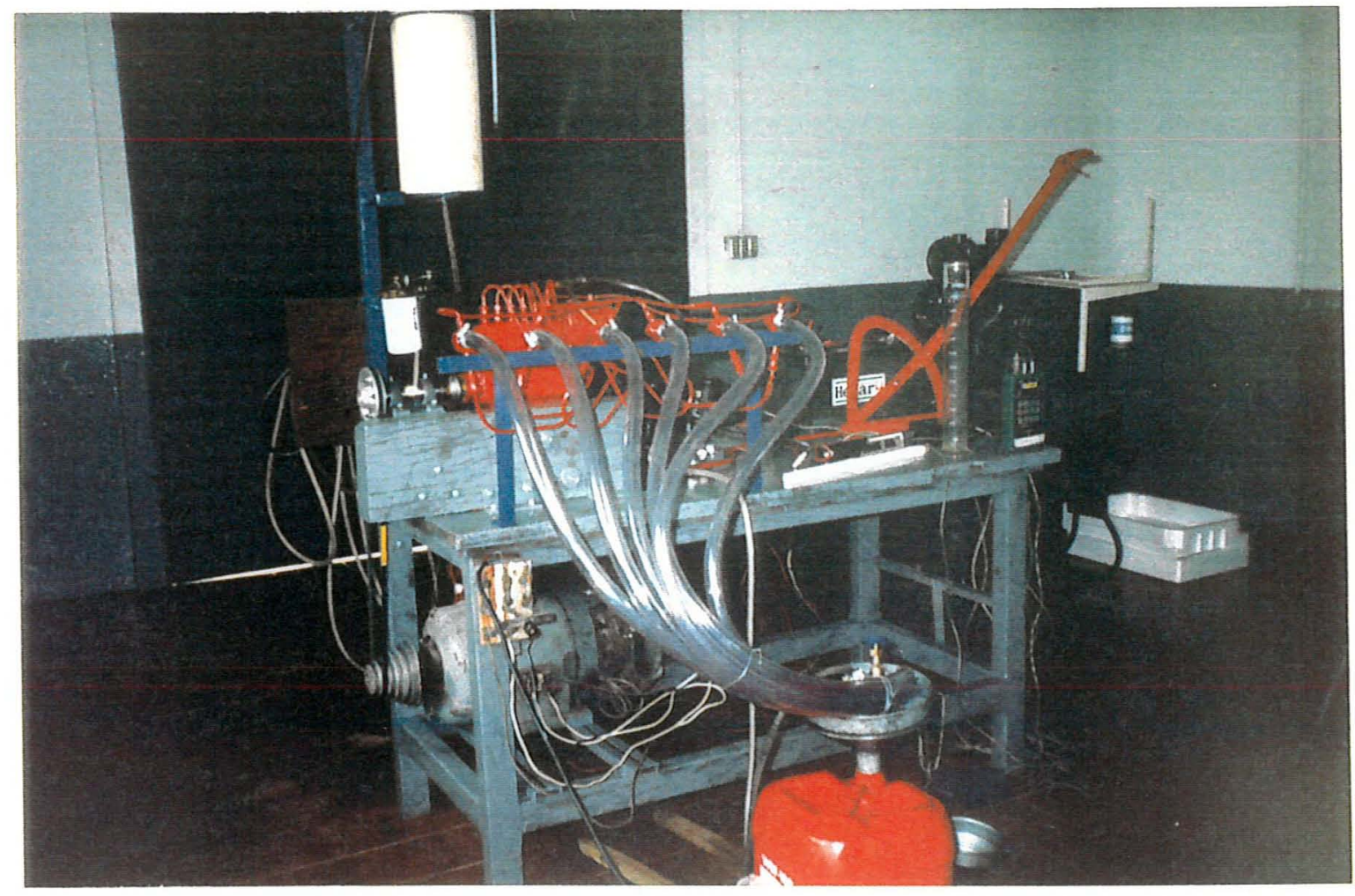

Figura 3. Bancada para calibração do medidor de combustivel.

\subsubsection{Laboratório para análises tecnológicas}

O laboratório para análises tecnológicas, utilizado para o experimento foi o da própria Usina Dabarra.

\subsection{Métodos}

Para a caracterização das condições do canavial, utilizou-se, metodologia apresentada por Ripoli (1996) , contemplando as seguintes determinações:

\subsubsection{Porte do canavial}

Utilizou-se de um triângulo retângulo de ferro, padrão, a fim de se verificar o ângulo do posicionamento dos colmos de cana em relação ao solo, na fileira da cana, em 12 pontos escolhidos ao acaso na área experimental. Foram contadas e registradas as quantidades de colmos eretos, acamados e deitados. A área foi, originalmente sistematizada para a colheita mecânica, com um espaçamento de plantio de $1,4 \mathrm{~m}$. 


\subsubsection{Densidade média dos colmos e matéria estranha vegetal}

Foram demarcados ao acaso na área experimental, 12 pontos numa área de 3,0 por $1,4 \mathrm{~m}$, conforme ilustrado na figura 4 . Nelas foram coletadas todas as, massas vegetais (colmos, ponteiros, folhas verdes e folhas secas), levando-as até as lonas plásticas. Contou-se o número de colmos e, obteve-se seus pesos e dos demais constituintes, separadamente através de célula de carga e display digital. Estas determinaçōes objetivaram obter a estimativa da produtividade agrícola do canavial e do palhiço. Foram calculados a média aritmética, desvio padrão e coeficiente de variação, para cada determinação dos 12 pontos amostrados.

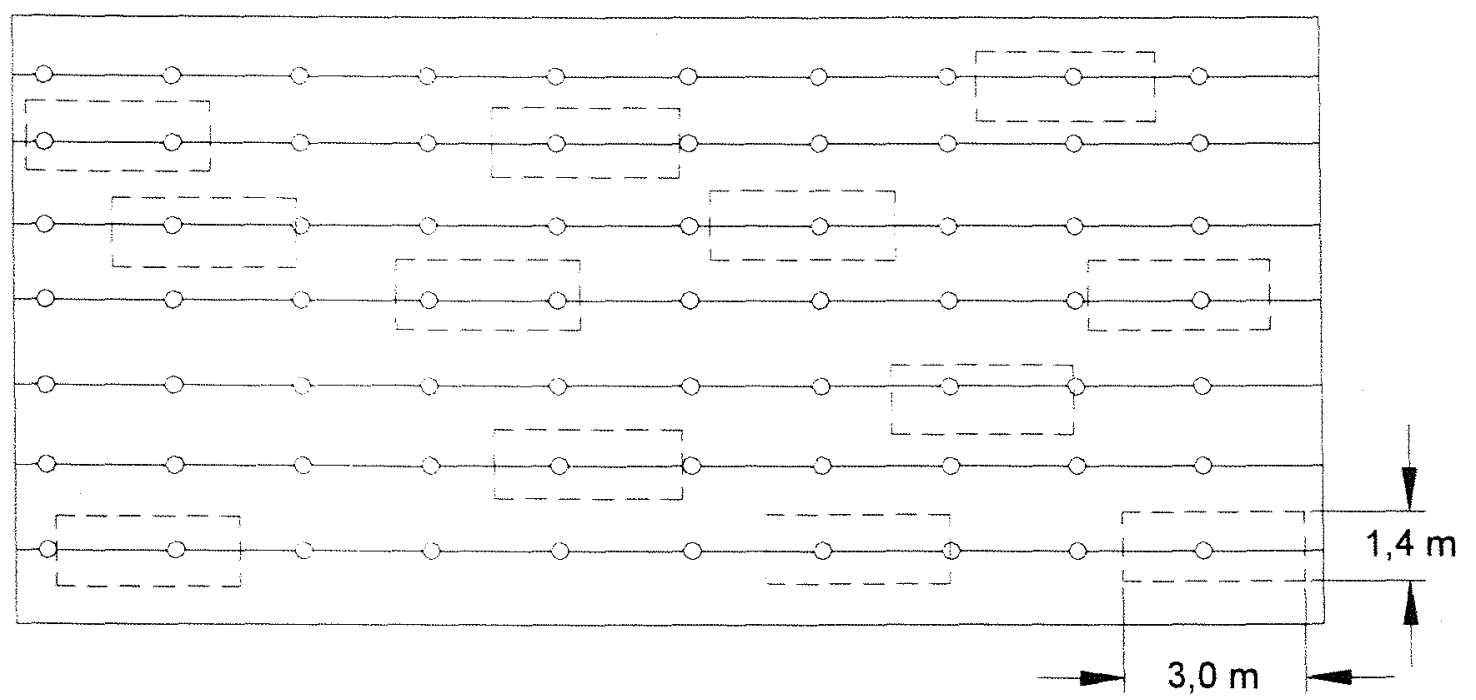

Figura 4. Desenho esquemático das áreas de coleta, para determinação do porte, produtividade agrícola dos colmos e caracterização da biomassa.

\subsubsection{Comprimento médio dos colmos}

Os colmos coletados das 12 áreas amostrais, tiveram seu comprimento medido, obtendo-se a média aritmética da amostra total.

\subsubsection{Teor de água do solo}

Coletaram-se, ao acaso, 10 amostras de solo, à profundidade de 0 a $10 \mathrm{~cm}$, próximo as fileiras de plantio, imediatamente após a passagem da colhedora em cada fileira de ensaio. As amostras de solo coletadas foram armazenadas em latas de alumínio, lacradas com fita adesiva, a fim de se evitar a evaporação, até a execução 
das determinações laboratoriais. O teor de água do solo foi determinado pelo método gravimétrico após secagem em estufa a $105^{\circ} \mathrm{C}$ por 24 horas, conforme relatado por Kiehl (1979).

\subsubsection{Granulometria do solo}

A coleta de amostras foi a mesma descrita no item 3.2.4, determinada segundo método de Steel \& Bradfield (1934).

\subsubsection{Idade e grau de maturação da cultura}

A cultura de cana-de-açúcar no talhão estudado, foi plantada em 1994. Seu grau de maturação, foi determinado pelo laboratório da Usina Dabarra, utilizando método proposto por Zarpelon et al. (1978).

\subsubsection{Desempenho Operacional da colhedora}

O desempenho operacional da colhedora, definido neste trabalho, utiliza metodologia apresentada por Ripoli (1996), analisando as seguintes características de desempenho: capacidade de colheita, consumo de combustível, perdas e qualidade da matéria- prima.

Foram realizados 4 grupos de determinações, correspondentes a 4 niveis de velocidades preestabelecidas, com quatro repetições em cada nivel de velocidade, totalizando 16 determinações de desempenho. A colhedora foi submetida à operação de colheita nas seguintes velocidades operacionais adotadas: $V_{1}=1,5 \mathrm{~km} \cdot \mathrm{h}^{-1}, V_{2}=3,0$ $\mathrm{km} \cdot \mathrm{h}^{-1}, V_{3}=5,0 \mathrm{~km} \cdot \mathrm{h}^{-1}$, e $V_{4}=7,0 \mathrm{~km} \cdot \mathrm{h}^{-1}$.

Os ajustes dos niveis de velocidade, foram conseguidos, através de determinações preliminares onde, foi instalado um equipamento odométrico como indicador de velocidade. Segundo informações colhidas junto aos fabricantes de colhedoras de cana, não se utilizam em outros paises ensaios com o despontador ligado, assim os ensaios foram realizados com o despontador desativado e posicionado na parte mais alta, acima das pontas dos colmos, ou seja sem operar.

Como preparação para os ensaios, colheu-se 10 metros de cada lado do talhão, a fim de eliminar o efeito bordadura, onde as fileiras de cana nas divisões do talhão podem apresentar condições marcadamente diferentes aos do interior do talhão. $A$ colhedora sofreu regulagens, a fim de poder apresentar o máximo de seu 
desempenho, para as condições de campo.

As velocidades efetivas das colhedoras foram determinadas por cronometria, ao longo de 100 metros nas fileiras de cana. Cada ensaio foi realizado colhendo-se uma fileira de cana. Ao final de cada repetição, a colhedora cessava o deslocamento e permanecia com seu funcionamento interno (fracionamento dos colmos, limpeza, elevação e descarregamento da matéria-prima), até o processamento final do material colhido ao longo da fileira de cana.

O processo na colheita da fileira ensaiada, se deu da maneira seguinte: demarcava-se um ponto paralelo no início da fileira da cana com uma estaca e um ponto na colhedora, através de uma marca com fita adesiva situado na posição das lâminas de corte basal.

O operador ciente, através de rádio comunicador, colocava em marcha à colhedora em velocidade pré-estabelecida uns 20 metros antes do ponto determinado como de partida, a fim de estabilizar a velocidade da máquina. Ao atingir o ponto demarcado de partida, uma pessoa próxima, dava o sinal de início do ensaio, através do abaixamento de uma bandeirola, e outra pessoa posicionada no fim dos $100 \mathrm{~m}$, em ponto demarcado através de outra estaca, acionava o cronômetro, que seria desacionado quando a colhedora tivesse com sua marca do corte basal na posição da estaca de chegada. Neste momento o cronometrista avisava por rádio o operador da colhedora para cessar imediatamente o deslocamento da máquina, fazia a contagem do tempo de colheita nos $100 \mathrm{~m}$ e, a leitura do consumo de combustível.

A cana colhida ao longo dos $100 \mathrm{~m}$ na linha da cana, era carregada em uma unidade de transbordo, que se deslocou paralelamente à colhedora durante o ensaio.

O descarregamento ocorreu em carretas posicionadas no carreador que transportaram a matéria-colhida em cada repetição, para a Usina, a fim de se determinar seu peso. No veículo de transbordo, colocou-se dois tambores com capacidade de 100 litros cada um, a fim de se determinar os valores de tamanhos de rebolos, cisalhamento dos rebolos, matérias estranhas vegetal e para a realização de análises tecnológicas.

Após a colheita efetuada pela máquina, durante cada repetição, demarcou-se duas áreas ao longo da linha da cana, com 3,0 m de comprimento por 4,2 de largura, transversalmente a linha colhida, a fim de determinar as perdas, (figura 5). Após esta demarcação, recolheu-se, em sacos plásticos, toda a massa vegetal encontrada nesta 
área, tais como: folhas secas, folhas verdes, restos de colmos dilacerados, rebolos e raízes arrancadas pela operação. Restos de tocos (pedaços de colmos que permaneceram no solo devido ao corte basal da colhedora ter sido efetuado acima do solo), foram retirados rente ao solo, com facão. Todo esse material foi acondicionado nos sacos plásticos e etiquetados, sendo levado para uma área no carreador, sendo pesadas todas as frações separadamente, com a célula de carga e mostrador digital, para a determinação das perdas no campo.

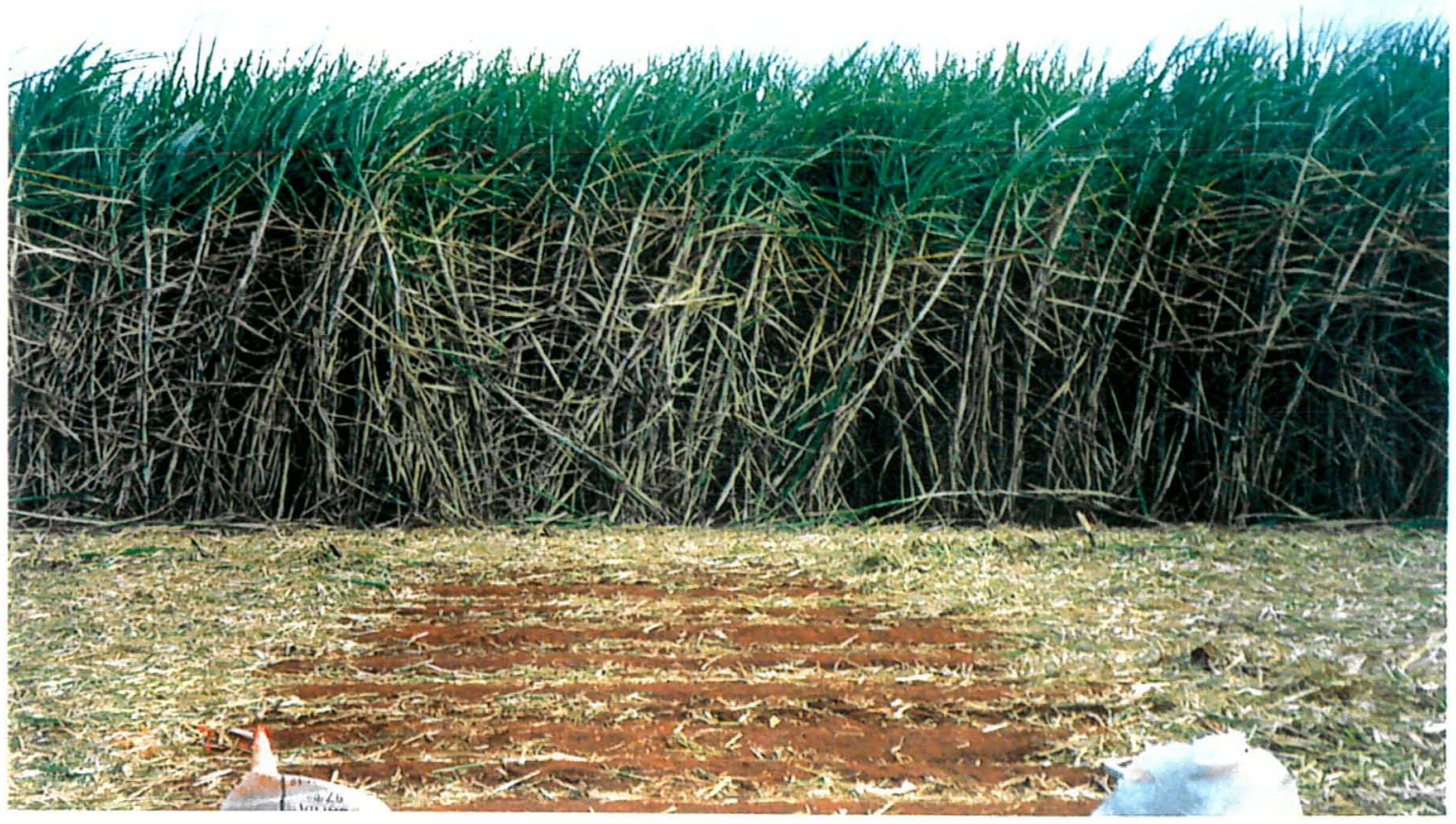

Figura 5. Vista da área de coleta de perdas no campo, resultantes das diversas repetições efetuadas.

\subsubsection{Capacidade de colheita}

Foram analisados os parâmetros: Capacidade Efetiva Bruta $\left(C E_{b}\right)$, Capacidade Efetiva Liquida $\left(C E_{l}\right)$, Capacidade Operacional $(C O)$ e, Eficácia de Manipulação $\left(E M_{t}\right)$.

A Capacidade Efetiva Bruta $\left(C E_{b}\right)$, segundo Ripoli (1996) é a quantidade de matéria-prima processada pela colhedora por unidade de tempo na parcela padrão do 
ensaio, dada pela equação:

$C E_{b}(\mathrm{~kg} / \mathrm{s})=W_{e}(\mathrm{~kg}) / t_{e}(\mathrm{~s})$

$$
C E_{b}(t / h)=W_{e}(k g) / t_{e}(s) * 3,6
$$

Onde:

$W_{e}=$ massa do produto colhido, depositado no veiculo de transporte durante o ensaio.

$t_{e}=$ tempo cronometrado no ensaio, no recolhimento da massa $W_{e}$.

A Capacidade Efetiva Liquida $\left(C E_{l}\right)$, é determinada pela Capacidade Efetiva Bruta multiplicada pela Eficácia de Manipulação, dada pela equação:

$C E_{l}(t / h)=C E_{b}(t / h) * E M_{t}(\%)$

A Capacidade Operacional $(C O)$, foi obtida a partir dos dados da Capacidade Efetiva Bruta em cada velocidade encontrada no ensaio, multiplicada pelas Eficiências de campo (EF) de 45, 55, 65 e $75 \%$ aqui determinadas, dada pela equação:

$$
C O(t / h)=C E_{b}(t / h) * E F(\%)
$$

A Eficácia de Manipulação $\left(E M_{t}\right)$, é determinada como sendo a relação entre a quantidade $\left(T_{c}\right)$ de rebolos de colmos colocados na unidade de transporte e a quantidade $(T C)$ de colmos existentes na fileira de plantio, no estado natural, segundo Ripoli (1996) e, dada pela equação:

$$
E M_{t}(\%)=\left(T_{c} / T C\right) * 100
$$


A variável $T C$, em colhedoras combinadas, é função do material não colhido e não carregado, resultando em perdas.

\subsubsection{Consumo de combustível}

Diz respeito à quantidade consumida de combustível pela colhedora durante 0 ensaio, em cada repetição, utilizando-se do medidor especificado em 3.1.5 e ilustrado através da figura 6 .

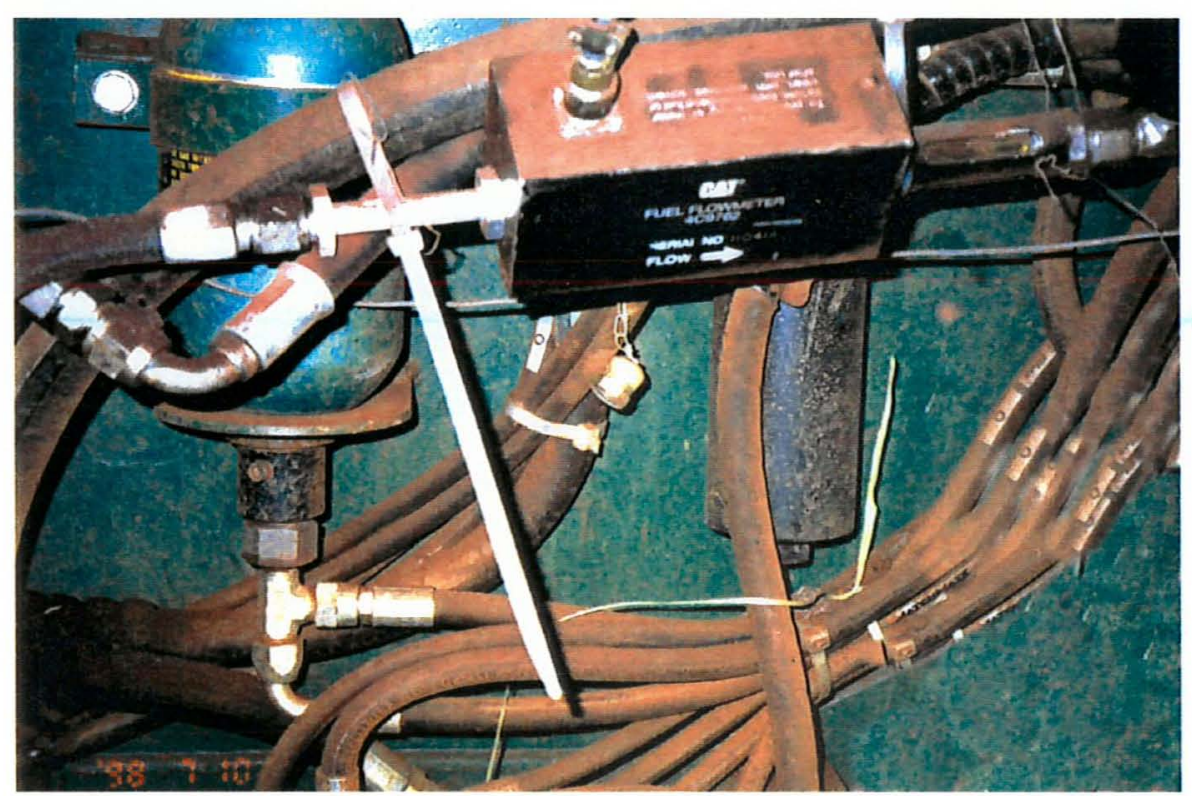

Figura 6. Medidor de combustível instalado na colhedora.

O Consumo de Combustível foi avaliado como: Consumo de Combustível horário $\left(I . \mathrm{h}^{-1}\right)$ e, Consumo de Combustível efetivo $\left(\mathrm{l} . \mathrm{t}^{-1}\right)$.

\subsubsection{Qualidade da matéria-prima no processamento de colheita}

Foi avaliada de forma quantitativa, contemplando os parâmetros: perda de matéria-prima industrializável no campo, limpeza do produto no processamento, qualidade tecnológica da matéria-prima, freqüência de comprimento e índice de cisalhamento dos rebolos.

A perda de matéria-prima industrializável no campo, é admitida neste trabalho como a matéria-prima cujo conteúdo em açúcar contido na matéria vegetal, fica no campo após a passagem da colhedora. 
A determinação da perda total desta matéria prima no campo $\left(P T_{c}\right)$, expressa em porcentagem, neste trabalho, é feita pela somatória das porcentagens de Colmos e suas Frações $(C F)$, Rebolos Inteiros $(R I)$ e suas Frações $(R F)$, pedaços de Rebolos na Soqueira $(R S)$ e pedaços de Rebolos no Ponteiro $(R P)$. Como neste experimento, a colheita foi feita com o despontador desligado, não foram determinados pedaços de rebolos no ponteiro, conforme relatado no item 3.2.7. As raizes expostas no terreno $(R T)$, encontradas após a passagem da colhedora, foram coletadas, pesadas e expressas em porcentagem, pois apesar de não conterem matéria prima no campo, serve como indicador de danos físicos na soqueira. A equação se apresenta como:

$P T_{c}(\%)=C F+R I+R F+R S+R P$

Obs: Nesta metodologia não se determinam as chamadas "perdas invisiveis".

A limpeza do produto no processamento, é aqui admitida como sendo o Teor de Matéria Estranha que acompanha a matéria-prima industrializável recolhida no veículo de transporte, sendo determinada através do Índice de Matéria Estranha Total (IT)em porcentagem, através da equação:

$I T(\%)=I V+I M$

Onde:

$I V=$ indice de matéria estranha vegetal, em \%;

$I M=$ índice de matéria estranha mineral, em \%.

O Índice de Matéria Estranha Vegetal (IV), é dado pela somatória dos Índices de Ponteiros $(I P)$, Índice de Folhas Verdes $\left(I F_{v}\right)$, Índice de Palhas $\left(I P_{a}\right)$ e, Índice de Raizes $(I R)$, todos em \%. 
O Índice de Ponteiros $(I P)$, é dado pela equação:

$I P(\%)=(P L+P A / C) * 100$

Onde:

$P L=$ quantidade de ponteiros livres, em $\mathrm{t}$;

$P A=$ quantidade de ponteiros aderidos aos rebolos, em $\mathrm{t}$;

$C=$ quantidade de material na unidade de transporte, em $\mathrm{t}$.

O Índice de Folhas $\left(I F_{v}\right)$, é dada pela equação:

$I F_{v}(\%)=\left(F_{v} / C\right) * 100$

Onde:

$F_{v}=$ quantidade de folhas verdes, em t;

$C=$ quantidade de material na unidade de transporte, em $\mathrm{t}$.

O Índice de Palhas $\left(I P_{a}\right)$, é dada pela equação:

$I P_{a}(\%)=\left(P_{a} / C\right) * 100$

Onde:

$P_{a}=$ quantidade de palhas, em t;

$C=$ quantidade de material na unidade de transporte, em $\mathrm{t}$.

O Índice de Raízes (IR), é dada pela equação:

$\operatorname{IR}(\%)=(R / C) * 100$ 
Onde:

$R=$ quantidade de raizes, em t;

$C=$ quantidade de material na unidade de transporte, em $t$.

O Índice de Matéria Estranha Mineral $(I M)$, é dado pela equação:

$I M(\%)=\left(T_{s} / C\right) * 100$

Onde:

$T_{s}=$ quantidade de solo presente na matéria prima na unidade de transporte, em t;

$C=$ quantidade de material na unidade de transporte, em $\mathrm{t}$.

A qualidade tecnológica da matéria-prima, é aqui admitida como sendo as características que determinam o padrão de qualidade da mesma, tendo sua importância no confronto destas características de qualidade antes e depois da colheita mecânica, a fim de se verificar a influência negativa ou não do processamento da colhedora nestas características.

A freqüência de comprimento dos rebolos, mostra a uniformidade do trabalho de fracionamento dos colmos pela colhedora, que podem refletir em problemas como: utilização destes rebolos para o posterior plantio mecanizado, visto que os mecanismos dosadores de plantadoras, não podem ser regulados a cada instante para atender uma grande variação no comprimento destes rebolos; rebolos muitos pequenos aumentam a área da massa do colmo que sofrerá deterioração; bem como existirá uma variação natural no número de gemas por variação de comprimento do rebolo, aumentando, teoricamente, a chance de menor uniformidade no espaçamento longitudinal no sulco de plantio.

Para esta determinação coletou-se, 20 amostras em cada repetição, fazendo-se a medição com uma régua de $50 \mathrm{~cm}$ de comprimento e precisão de $0,5 \mathrm{~cm}$. Em seguida foram determinados uma poligonal de freqüência com intervalos de $5 \mathrm{~cm}$.

$O$ indice de cisalhamento dos rebolos, mostra a qualidade do trabalho de 
fracionar os colmos, visto que aqueles que não sofrem um adequado cisalhamento, apresentando rachaduras de um ou em ambas as extremidades, o que aumenta a área de deterioração destes colmos, bem como poderá comprometer as gemas nestes colmos prejudicando uma posterior utilização para o plantio. Nesta determinação foi avaliado através de inspeção visual, em uma amostra de 20 rebolos por repetição a cada velocidade, verificando-se em percentagem, a quantidade de colmos perfeitos, macerados de um lado e de ambos os lados.

\subsubsection{Delineamento estatístico}

Adotou-se o delineamento inteiramente casualizado, com o fator velocidade de deslocamento em colheita da colhedora, em 4 niveis com 4 repetições em cada nível, totalizando 16 determinações. Os niveis de velocidade adotados foram: 1,5; 3,0; 5,0; $7,0 \mathrm{~km} \cdot \mathrm{h}^{-1}$. Utilizou-se o Sistema de Análise Estatística (SANEST), para aplicação do "teste F", a fim de verificar se houve diferença significativa entre as médias; onde foram encontradas diferenças significativas aplicou-se o "teste TUKEY", a fim de compara-las ao nível de $5 \%$ de significância.

\subsubsection{Desempenho Econômico da colhedora}

Para o desempenho econômico da colhedora, utilizou-se do método de orçamentação de custo anualizado equivalente - CAE, desenvolvido a partir do conceito de anuidade equivalente, para cálculo do custo anual da maquinaria, recomendado por Noronha et al. (1981).

A determinação de custo anualizado equivalente se baseia numa estrutura de fluxo de caixa que espelhe o investimento inicial na colhedora, todas as despesas previstas durante sua permanência na empresa e o seu valor de revenda ou sucateamento, após cumprido um razoável período de vida útil. Após a montagem do fluxo de caixa, calcula-se o custo anualizado equivalente utilizando-se a seguinte equação:

$$
C A E_{t a}(T)=V P_{T} * F R C
$$

onde: 
$t_{a}=$ taxa unitária de desconto;

$T$ = tempo de permanência (em anos) da máquina na empresa;

$V P_{T}=$ valor presente, no ano $T$, em US\$;

$F R C==$ fator de recuperação do capital.

Os termos $V P_{T}$ e $F R C$, são calculados por:

$$
\begin{aligned}
& V P_{T}=V T+\sum_{t=1}^{T} \frac{D_{t}}{(1-t)^{t}}-\frac{V F_{t}}{(1+t)^{T}} \\
& F R C=\frac{t *(1+t)^{T}}{(1+t)^{T}-1}
\end{aligned}
$$

Onde:

$V I=$ Valor inicial (máquina nova), em US\$;

$D_{t}=$ Total de despesas do ano, em US\$;

$t=$ ano considerado, da vida útil, em número de anos;

$V F_{t}=$ valor final (de revenda ou sucateamento), em US\$.

Conforme se observa na equação (13), é permitido transformar uma anuidade variável ("fluxo de caixa") numa anuidade constante cujo valor presente, calculado à taxa $t$, é igual ao valor presente do fluxo de caixa original do bem de capital - a colhedora. Portanto, a diferença entre o método convencional e o CAE reside, principalmente, na forma como é considerada a remuneração do capital da empresa. Como explica Noronha et al. (1992), em ambos os casos utiliza-se uma taxa de juros que representa o custo de oportunidade do capital da empresa mas, enquanto no método convencional ela se aplica sobre valores médios do capital empatado, no método CAE ela é usada como taxa de desconto (e de anualizacão) do fluxo de caixa.

A metodologia CAE parte do princípio que a decisão do investimento em máquinas compromete despesas não apenas no momento da compra, mas durante todo o tempo de sua vida produtiva. Assim, a orçamentação de custos dos serviços, 
que no caso deste trabalho, a colhedora devera prestar, em qualquer dos anos de sua vida útil, é baseada na constituição de um fluxo de caixa (despesas em dinheiro) que a decisão de comprar a máquina compromete para o futuro. Assim, os itens levados em conta na construção do fluxo de caixa da colhedora são os seguintes:

- Valor inicial - VT e Valor residual - $V R_{t}$ após um tempo t de vida útil;

- Juros - JU;

- Seguro - SE, Alojamento - $A L$ e Administração - $A D M$;

- Combustivel - CCO, Lubrificantes - $L U$, e Comboio de manutenção/abastecimento - $C M A$;

- Peças de reposição - $P R$ e mão de obra em serviços mecânicos - $S M$;

- Mão de obra de operador - MO .

Adotou-se para os cálculos, o dólar norte-americano como unidade monetária, por ser uma moeda utilizada nos negócios internacionais.

\section{Valor inicial $(V I) \&$ Valor residual $\left(V R_{t}\right)$}

Estes valores são conceitos utilizados para efeito de depreciação, onde o (VI), é aquele na data em que a máquina ficou disponivel para uso na empresa.

O $\left(V R_{t}\right)$, é o valor da colhedora ao final de um tempo $t$ de sua vida útil $(V U)$, que, no presente trabalho, é de 6 anos e utilizado aqui, como valor residual mensal $\left(V R_{m}\right)$. Quando $t=0, V R_{0}=V I$ e quando $t=V U, V R_{V U}=V S$, ou seja, valor de sucata.

Por sua vez, a depreciação econômica aqui obtida, o foi pelo método da linha reta, onde o valor da depreciação (TD), em US\$.ano-1 é calculado por:

$T D=\frac{V I-V F}{V U}$

Onde:

$V F=$ valor final em US\$, assumindo o valor equivalente a $10 \%$ do valor inicial, como 
depreciação total ao final de $V U$, (Utilizou-se este critério para o valor de $V F$, por ser de uso tradicional dos órgão governamentais no Brasil);

$V I=$ valor inicial (pago na aquisição) em US\$, considerado neste trabalho como: US\$ 305.000,00;

$V U=$ vida útil da colhedora, considerada neste trabalho, como: 18900 horas ou 6 anos de trabalho, (15h/dia, 30 dias/mês, safra de 7 meses/ano).

Portanto, o valor residual ao final do periodo $t$ de vida útil, em US\$, é fornecido por:

$V R_{t}=V I-(t \times T D)$

Onde:

$t=$ tempo $t$ de vida útil, em número de anos.

Juros $(J U)$

Define-se como sendo o produto do valor do dinheiro envolvido na compra da colhedora pela taxa de juros, sobre o valor da residual da colhedora em cada ano de uso.

Considerou-se a taxa de juros igual a $12 \%$ a.a., conforme Banco do Brasil para financiamento de máquinas agrícolas para o ano de 1999.

Obtendo-se o Juros, em US\$ no ano, como:

$J U_{a}=V R_{a} \times 0,12$

Onde:

$V R_{a}=$ Valor residual da colhedora

Seguro $(S E)$, Alojamento $(A L)$ \& Administração $(A d m)$

Estas parcelas, constituem direta ou indiretamente, dispêndios efetivos não 
caixa. Aqui, foram adotados os seguintes critérios:

No caso do seguro (SE) em US $\$ . h^{-1}$, adota-se a taxa com valor de $10,4 \%$ a.a., idêntico ao praticado pelo Banco do Brasil, nos financiamentos de maquinaria agrícola no ano de 1999, obtendo:

$S E_{a}=0,104 \times V R_{a}$

No caso do alojamento $(A L)$ e administração $(A d m)$, considera-se como um nivel máximo de dispêndio, em US $\$ h^{-1}$, da ordem de $50 \%$ do valor do prêmio de seguro, ou seja:

$(A L+A d m)_{a}=0,5 \times S E_{a}$

Custo com consumo de combustível ( $C C O$ )

O custo de combustível em US $\$ \cdot h^{-1}$, foi determinado pela equação:

$C C O=C C \times P_{\text {comb }}$

Onde:

$C C=$ consumo de combustível em $\mid \cdot h^{-1}$, a cada operação de colheita, para a colhedora, determinado pelo medidor de combustível conforme citado no item 3.2.7.2., sendo posteriormente convertido em litros por tonelada de cana colhida para cada capacidade operacional em função da eficiência de campo estimada.

$P_{\text {comb }}=$ Preço do diesel em US\$..$^{-1}$, praticado na bomba de abastecimento da Usina em estudo de 0,23 US\$..$^{-1}$.

\section{Custo com Lubrificantes $(L U)$}

Aqui, os dispêndios com lubrificantes, envolveram aqueles ocorridos devido a trocas periódicas e àqueles oriundos de consumo (caso de óleo do Carter do motor), ou de eventuais vazamentos (em geral, quando ocorre a necessidade de substituição 
de mangueiras estouradas). No caso de trocas periódicas e oriundas do consumo (óleo lubrificante), foi adotado o consumo de $0,141 . \mathrm{h}^{-1}$, valor médio observado nos registros do setor de manutenção mecânica da Usina em estudo para a safra 98/99.

No caso da estimativa do consumo adicional de lubrificantes e óleo do sistema hidráulico ou hidrostático, a Usina em estudo, não dispõe de registros de campo da maquinaria que permitam valores confiáveis. Considerou-se, portanto, neste trabalho, a informação de Braunbek (1991), sobre registros nas usinas que utilizam colhedoras DM-6000, de um consumo da ordem de $30-40 \mathrm{ml}$ de óleo do sistema hidráulico por tonelada de cana colhida. Portanto, adotou-se neste trabalho, um consumo médio de $0,0351 . t^{-1} \times$ Capacidade operacional na velocidade de ensaio na eficiência admitida $\left(\mathbf{t} . h^{-1}\right)$.

Portanto o custo com lubrificantes em US $\$ \cdot h^{-1}$, é obtido pela equação:

$$
C L U=\left(L U_{p}+L U_{v}\right)
$$

$L U_{p, v}=($ volume / tempo de troca $) \times$ Custo do litro de óleo

Onde:

$L U_{p}=$ Custo do consumo de óleo lubrificante em US\$. $h^{-1}$, devido a trocas periódicas e de consumo (caso de óleo do Carter do motor), admitido o consumo de acordo com Informação fornecida pela Usina em estudo, de 0,14 I. $\mathrm{h}^{-1}$.

$L U_{1}=$ Custo do consumo de óleo hidráulico em US $\$ \mathrm{~h}^{-1}$, proveniente de eventuais vazamentos (como caso de mangueiras estouradas), admitido neste trabalho um consumo de $0,035 \mathrm{I}^{-\mathrm{t}^{-1}} \times$ Capacidade operacional na velocidade de ensaio na eficiência admitida $\left(t \cdot h^{-1}\right)$.

Foram adotados neste trabalho, os custos do litro de óleo lubrificantes (motor) de 1,40 US $\$ . I^{-1}$ e óleo hidráulico de 1,33 US $\$ . I^{-1}$.

\section{Custo com Comboio de manutenção \& Abastecimento (CMA)}

Este dispêndio em US\$. $\mathrm{h}^{-1}$, está associado ao uso deste comboio pela colhedora, esta determinação foi feita a partir do gasto feito pela Usina em estudo na safra, onde dividiu-se os custos dos comboios pelo números de colhedoras que faziam parte da 
frente de trabalho, e dividiu-se este custo comboio-colhedora pelo número de horas anuais de trabalho, obtendo-se assim o $C M A$ de 1,92 US\$. $\mathrm{h}^{-1}$.

Custo de Peças de reposição $(P R)$ \& Serviços mecânicos $(S M)$

O custo de peças de reposição em US\$. $h^{-1}$, baseado em relatório de manutenção, foi fornecido pela Usina em estudo e, representa todos os gastos com peças que precisaram ser substituídas em um ano, dividido pelo número de horas trabalhadas neste ano pela colhedora. Neste custo estão incluídos todas peças substituídas por manutenção preventiva (periódica) como filtros, correias, outros; como de manutenção corretiva (após quebra no campo).

O item serviços mecânicos ( $S M$ ), gera um custo (serviços), na substituição das peças de duas formas diferentes: a primeira, é a despesa direta de mão-de-obra para realizar o trabalho de desmontagem e montagem das peças de reposição; e a Segunda, é a despesa indireta, representada pelo trabalho que a colhedora deixou de executar e que poderia ser executado pelo meio alternativo, colheita manual e carregamento mecânico mais o salário do operador da colhedora.

Neste trabalho, somente a despesa direta foi levada em consideração. As despesas diretas de mão-de-obra de serviços mecânicos, foram fornecidas pela Usina em estudo, baseado em relatório de manutenção, onde representa em US $\$ . h^{-1}$, o custo do setor de oficina por hora, dividido pelo tempo em horas, que a colhedora ficou em trabalho na oficina, avaliado em um ano, resultando num dispêndio (SM) de 1,58 US\$. $h^{-1}$.

\section{Custo da mão-de-obra do operador da colhedora ( $M O)$}

Este dispêndio em US $\$ . h^{-1}$, representa o salário hora global deste operador, compreendendo o salário nominal mais os encargos sociais, obtido através de informações do setor de recursos humanos da Usina em estudo; resultando $(M O)$ de 2,10 US $\$ . h^{-1}$.

\section{Fluxo de caixa total: despesas de propriedade e operacionais}

De posse dos dados anteriores, montou-se uma planilha de fluxo de caixa total, formados pelas despesas de propriedade e operacionais. Através da somatória destas 
despesas, encontrou-se o custo-hora em US $\$ . h^{-1}$, da colhedora, durante sua vida na empresa.

Dividindo-se o custo-hora, pelos dados de capacidade operacional encontrados nas determinações do experimento, através da multiplicação dos dados da capacidade efetiva bruta pelas eficiências de campo adotadas (45, 55, 65 e $75 \%$ ), obteve-se o custo em US\$ por tonelada de cana colhida para os cenários encontrados, através das velocidades e eficiências.

Portanto esta relação em US\$. $\mathrm{t}^{-1}$, é obtida pela equação:

$U S \$ / t=(U S \$ / h) /(t / h)$

Utilizando os cenários obtidos, inferiu-se várias possibilidades de custos para a colhedora em estudo.

Adotou-se neste trabalho, os valores obtidos na Safra $98 / 99$, da Usina em estudo como segue:

Total de dias trabalhados na Safra: 210 dias

Total de horas trabalhadas na Safra: 3150 horas

Total de horas trabalhadas por dia: 15 horas

Total de horas, em 6 anos de vida da máquina: 18900 horas

Câmbio - Valor do Real Brasileiro frente ao Dólar Americano : 1,88 


\section{RESULTADOS E DISCUSSÃO}

\subsection{Caracterização das condições do canavial}

4.1.1 Porte do canavial, declividade, teor de água e granulometria do solo Encontrou-se um canavial com o porte ereto, conforme pode ser visto na tabela 1 dos anexos e na figura 7.

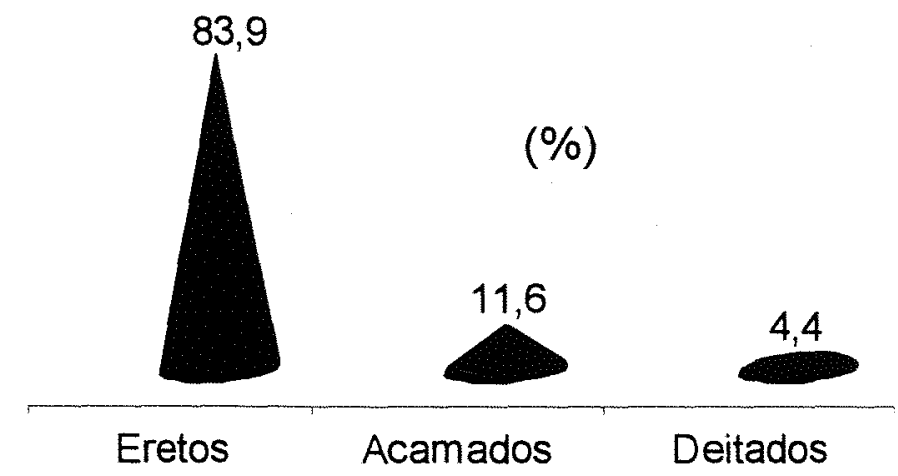

Figura 7. Resultados da caracterização percentual do porte do canavial

A declividade verificada da área, variou de 0 a $2 \%$.

Os valores de umidade verificados, variaram de 9,12 a 21,45 e; os de granulometria, foram: Areia total 31,4 ; Silte 11,8 e argila 56,8 , todos em $\%$.

\subsubsection{Produtividades obtidas}

Analisando - se os resultados obtidos na área de coleta, foram encontrados os valores apresentados na tabela 2 dos anexos e na figura 8. 


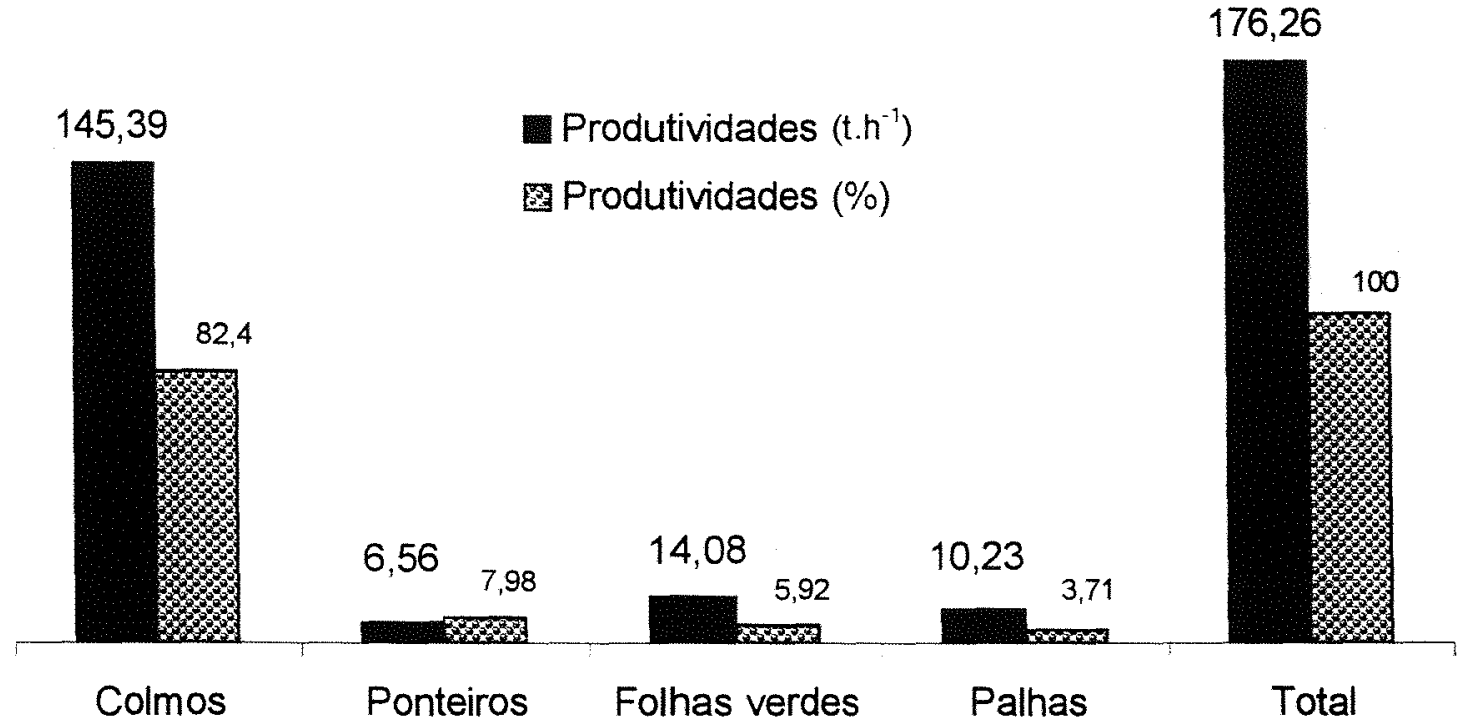

Figura 8. Caracterização das produtividades da biomassa, antes da ação da colhedora.

Observa-se que a Produtividade Total foi de $176,26 \mathrm{t} . / \mathrm{ha}^{-1}$, considerada alta, conforme relata Ripoli (1996). A produtividade Agricola (colmos) obtida, foi de 145,39 t.ha ${ }^{-1} e$, quando comparada com a produtividade média de colmos recolhidos pela colhedora, conforme apresentado na tabela 6 e figura 9 , nota-se que a diferença da média das Produtividades para as 4 velocidades de deslocamento da máquina no ensaio, que se mostraram não ter influência significativa ao nível de $5 \%$ pelo teste de Tukey, em relação à Produtividade do canavial è de apenas 10,98 \%.

Esta diferença pode estar associada à variação estatistica do intervalo de confiança, bem como a perdas invisíveis (não analisada neste trabalho), que pode estar em torno de 3,2 \% Moraes (1992), 3,56 \% Furlani et al. (1993) e, 5,4 \% Moraes \& Neves (1997). 


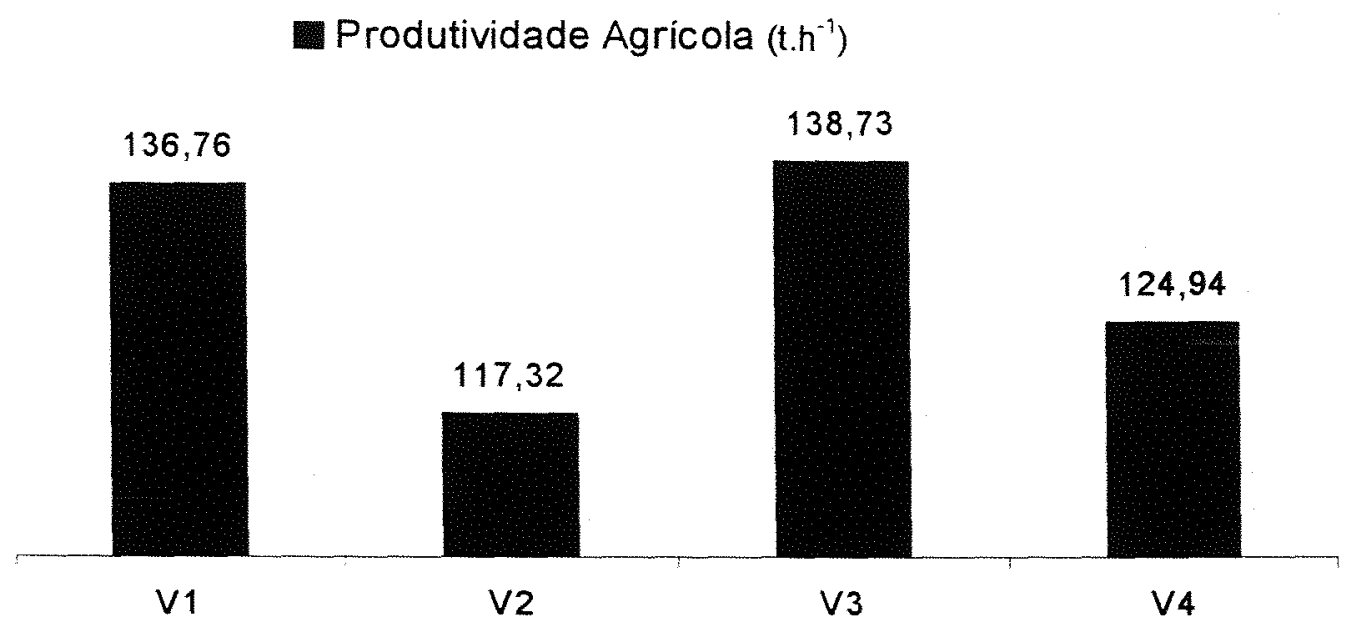

Figura 9. Resultados de produtividades agrícolas, com base no material colhido, nas velocidades estudadas.

\subsubsection{Comprimento médio dos colmos}

Observou-se que o comprimento médio dos colmos encontrado foi de $3,20 \mathrm{~m}$ com uma variação de $\pm 0,07 \mathrm{~m}$ do intervalo de confiança com $95 \%$ de probabilidade, conforme apresentado na tabela 3, dos anexos. Este comprimento dos colmos pode ser considerado alto conforme mostra Furlani Neto (1984), onde a média de altura dos colmos das variedades no Estado de São Paulo varia em torno de 2,7 m.

\subsubsection{Grau de maturação da cultura}

Os parâmetros de qualidade, foram determinados no laboratório da Usina e são apresentados na tabela 4 dos anexos e na figura 10. 


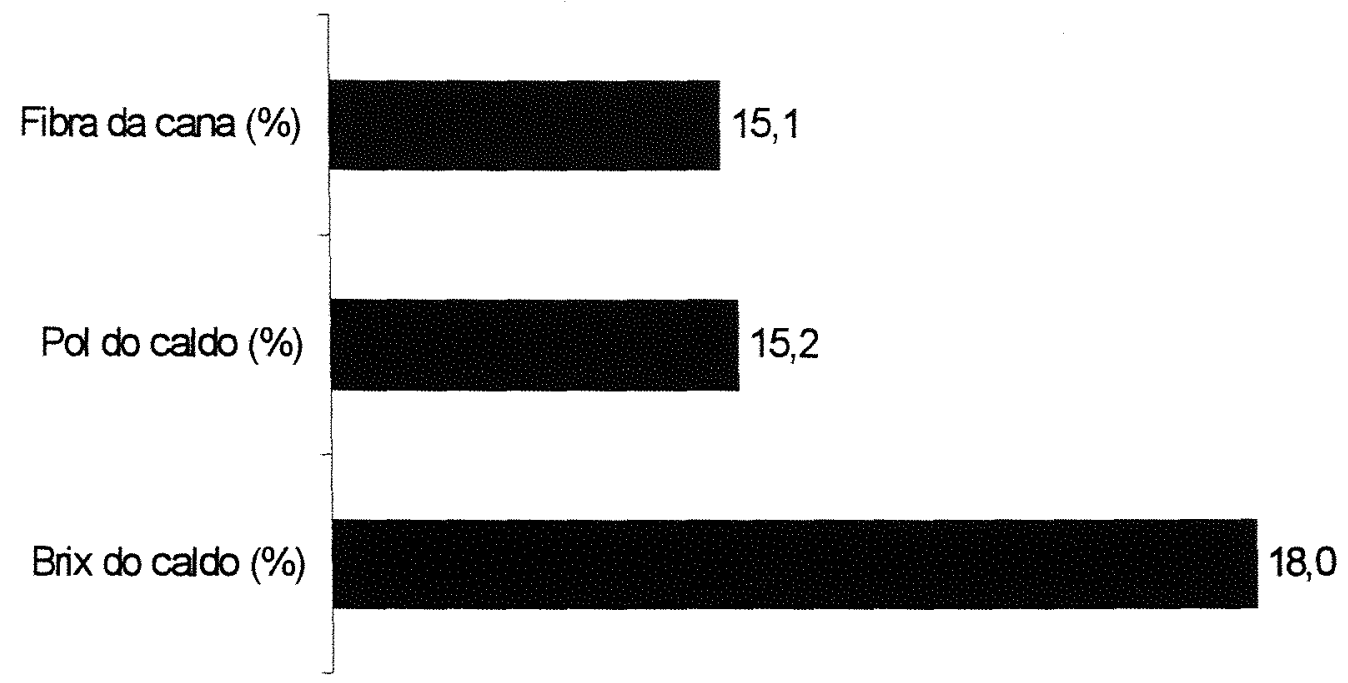

Figura 10. Resultados obtidos de qualidade da matéria-prima.

Estes resultados para cana crua, estão similares ao encontrado por Melo et al. (1988) que foram para Fibra \% da cana de 12,19; para Pol \% do caldo de 15,9 e para Brix $\%$ do caldo de 18 , mostrando que a variedade em estudo apresentou-se um pouco fibrosa em relação ao apresentado por este autor.

\subsection{Desempenho Operacional da colhedora}

\subsubsection{Velocidade efetiva de deslocamento da colhedora durante a colheita}

As médias das velocidades de deslocamento da colhedora durante os ensaios, são apresentadas através da tabela 9 dos anexos, bem como na figura 11. Observase, na tabela 9 dos anexos, que as velocidades são diferentes entre si, confirmado pelo teste de Tukey ao nivel de significância de 5\%. 


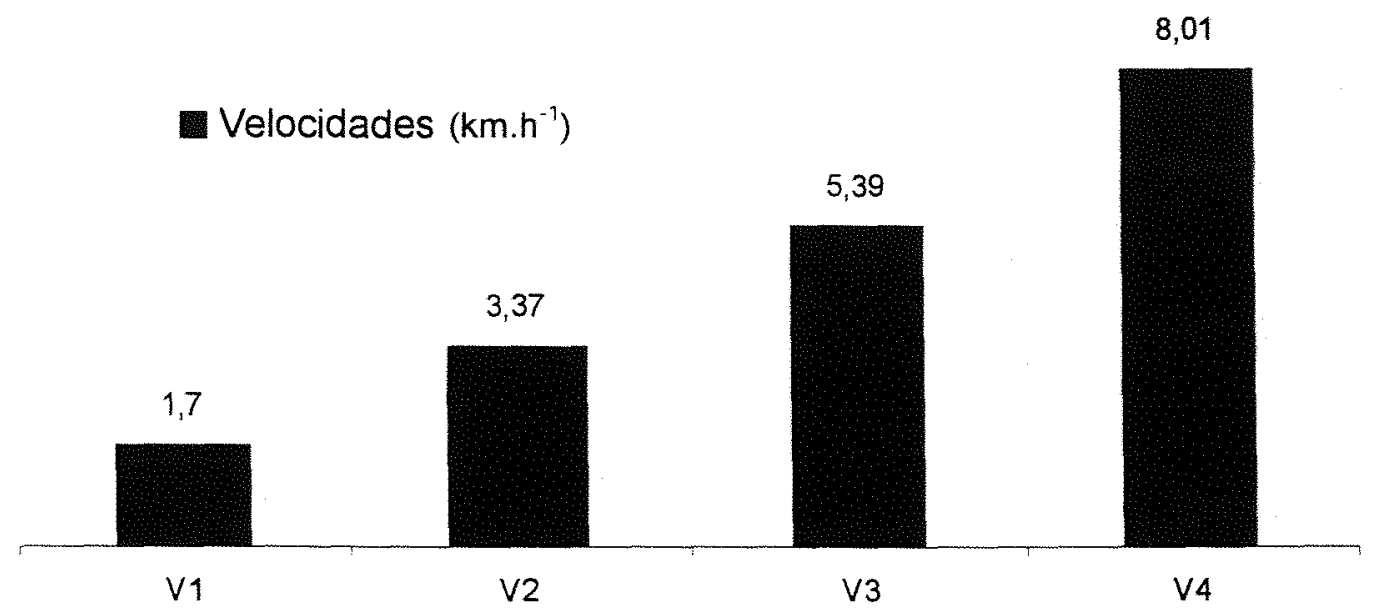

Figura 11. Resultados obtidos das médias das velocidades de deslocamento da colhedora, durante os ensaios.

Normalmente os fabricantes de colhedoras apresentam, através de catálogos técnicos que as colhedoras podem trabalhar com velocidades de até $9,0 \mathrm{~km} / \mathrm{h}$, mas atualmente no Estado de São Paulo, conforme informado por produtores de cana-deaçúcar, as colhedoras não tem ultrapassado os $5 \mathrm{~km} / \mathrm{h}$.

\subsubsection{Capacidade Efetiva Bruta $\left(\mathrm{CE}_{\mathrm{b}}\right)$}

Observa-se pela tabela 11 dos anexos, que a Capacidade Efetiva Bruta não sofreu influência significativa das velocidades $V 1$ e V2. Houve influência significativa entre as velocidades $\mathrm{V} 1$ e V2 quando comparadas com as velocidades V 3 e V4. Todos analisados através de teste de tukey ao nivel de significância de $5 \%$. A figura 12 apresenta os valores médios obtidos. 


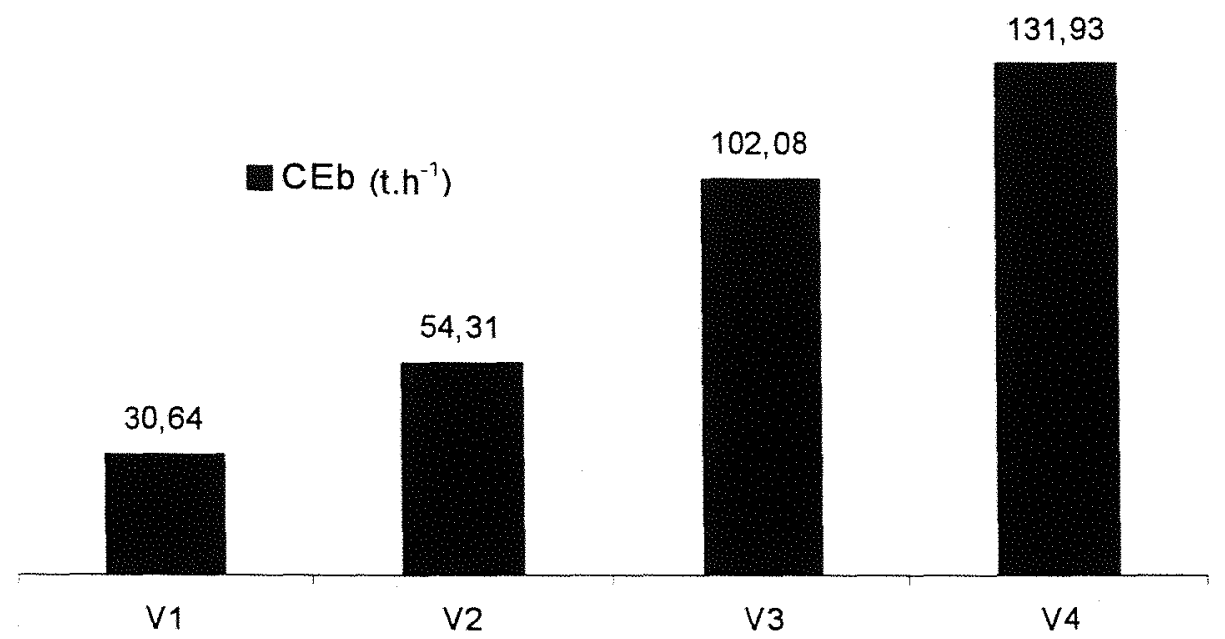

Figura 12. Resultados obtidos das médias da Capacidade Efetiva Bruta para as velocidades utilizadas nos ensaios.

A Capacidade Efetiva Bruta, é utilizada neste ensaio, para o cálculo de custos da colhedora, uma vez que não se levam em consideração as perdas no campo e as impurezas contidas na carga colhida. Analisando apenas a quantidade de material liberado no veículo de transporte, a Capacidade Efetiva Bruta na velocidade V4 é a maior, com 131,93 t.h ${ }^{-1}$. Mialhe e Carraro Neto (1993), apresentam uma Capacidade Efetiva Bruta de 83,83 t.h $\mathrm{h}^{-1}$ e 75,64 t.h $\mathrm{h}^{-1}$ para velocidades em colheita de 3,67 e 4,04 $\mathrm{km} \cdot \mathrm{h}^{-1}$ respectivamente, com colhedora CC-2000. Furlani Neto et al. (1996), obtiveram uma Capacidade Efetiva Bruta de 57,78 e 66,79 t.h $\mathrm{h}^{-1}$, para velocidades em colheita de 4,65 e $5,5 \mathrm{~km} \cdot \mathrm{h}^{-1}$. Outros autores, conforme revisão bibliográfica, apresentam outros valores para capacidade efetiva, mas não relatam se é bruta ou liquida, e a que velocidades foram determinadas, o que mostra uma total falta de padronização metodológica a fim de que se possa fazer afirmações seguras que possibilitem a comparação entre colhedoras diferentes.

Verifica-se também, através da figura 13, que existe uma forte correlação linear entre a Capacidade Efetiva Bruta e as velocidades de deslocamento da colhedora nos ensaios. 


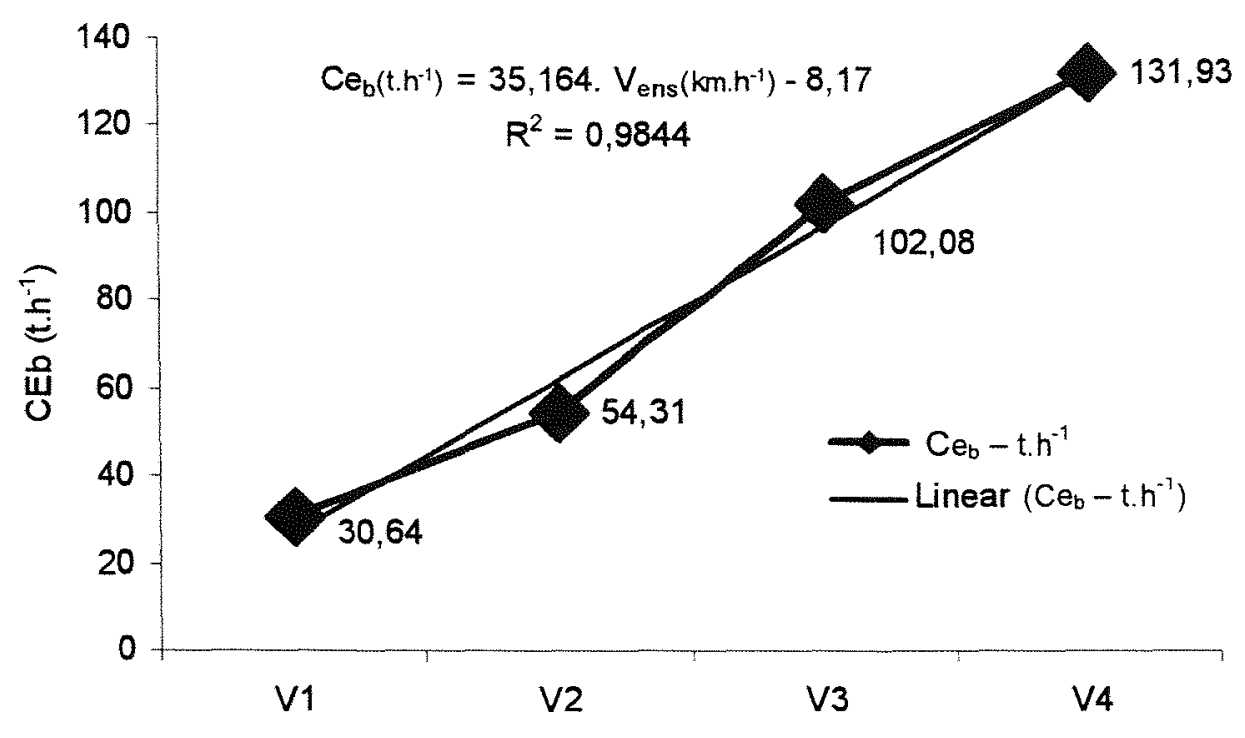

Figura 13. Correlação Linear da Capacidade Efetiva Bruta.

\subsubsection{Eficácia de Manipulação $\left(\mathrm{EM}_{\mathrm{t}}\right)$}

Observa-se pela tabela 13 dos anexos e a figura 14, que a variável Eficácia de Manipulação sofreu influência significativa da velocidade $V 1$ e não sofreu influência significativa nas demais velocidades $\mathrm{V} 2, \mathrm{~V}_{3}$ e $\mathrm{V} 4$; todas analisadas pelo teste de Tukey, ao nivel de significância de $5 \%$.

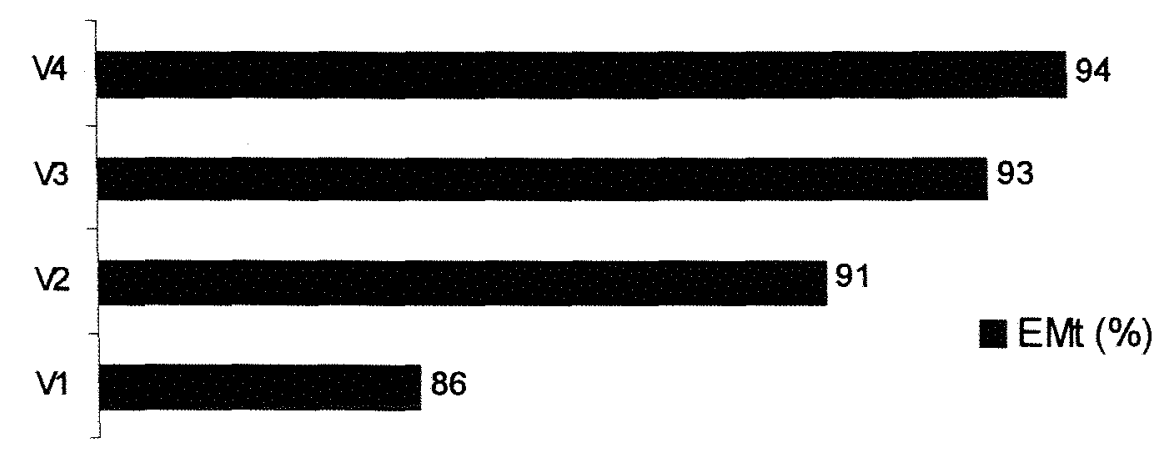

Figura 14. Resultados obtidos da Eficácia de Manipulação da colhedora para as velocidades utilizadas. 
Nota-se que a Eficácia de Manipulação, (definida por Ripoli, 1996, como sendo a porcentagem de matéria prima industrializável, disponivel na parcela padrão, que a colhedora foi capaz de recolher e processar, durante o ensaio), tem uma tendência de melhora conforme o aumento da velocidade de deslocamento da colhedora, chegando a $94 \%$ de eficiência na maior velocidade. A colhedora utilizada neste ensaio, mostra que seus subsistemas de corte, condução e carregamento, tendem a funcionam melhor conforme o aumento da velocidade de deslocamento, o que não é prática usual em outras máquinas. Mialhe e Carraro Neto (1993), encontraram uma Eficácia de Manipulação de $96,78 \%$ e 96,86 \% para velocidades em colheita de 3,67 e 4,04 km. $\mathrm{h}^{-1}$ respectivamente, com colhedora CC-2000, demonstrando esta tendência de aumentar a eficiência com o aumento da velocidade de deslocamento, bem como eficiências muito próximas do encontrado neste estudo.

\subsubsection{Capacidade Efetiva Liquida $\left(\mathrm{CE}_{1}\right)$}

Observa-se pela tabela 15 dos anexos, que a variável Capacidade Efetiva Liquida sofreu influência significativa nas 4 velocidades de ensaio conforme analise pelo teste de Tukey, ao nivel de significância de $5 \%$.

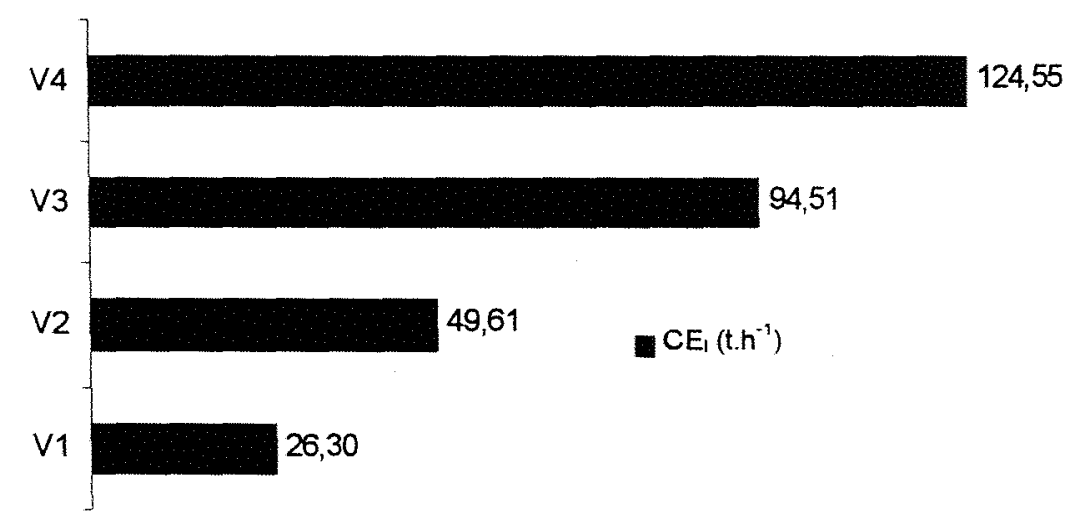

Figura 15. Resultados obtidos das médias das Capacidades Efetivas Liquida 0 para as velocidades estudadas.

Nota-se que a Capacidade Efetiva Liquida (Capacidade Efetiva Bruta pela Eficácia de Manipulação), aumenta conforme aumenta a velocidade de deslocamento da colhedora, atingindo na V4 a capacidade de $124,55 \mathrm{t}^{\mathrm{h}} \mathrm{h}^{-1}$. Mialhe e Carraro Neto 
(1993), encontraram uma Capacidade Efetiva Liquida de $73,47 \mathrm{t} . \mathrm{h}^{-1}$ para velocidade, de 3,67 km.h $\mathrm{h}^{-1}$ com colhedora CC-2000; Romero et al. (1993), encontraram Capacidades Efetivas que variam de 40 a 71 t.h $^{-1}$, em 6 variedades de cana diferentes a velocidades de deslocamento que variaram de 3,0 a $5,0 \mathrm{~km} . \mathrm{h}^{-1}$. Furlani Neto et al., encontraram Capacidades Efetivas de até $66,79 \mathrm{t} \mathrm{th}^{-1}$, assim como Soares et al. (1994) de, $60,4 \mathrm{t} . \mathrm{h}^{-1}$. Baseado nestes valores citados, pode-se inferir, que em nossa opinião, as capacidades efetivas liquida não tiveram grande evolução nas colhedoras de modelos novos, comparado a máquinas de modelos de 6 anos atrás.

\subsubsection{Capacidade Operacional (CO)}

As capacidades operacionais, neste trabalho, foram obtidas a partir de 4 Eficiências de Campo adotadas $(45,55,65,75 \%)$ a fim da obtenção de cenários, que possam exprimir situações diversas encontradas ou desejadas por produtores de canade-açúcar. Observa-se pela tabela 20 dos anexos e a figura 16 a seguir, que a variável Capacidade Operacional aumenta conforme aumenta a velocidade de deslocamento da colhedora e, evidentemente com o aumento da Eficiência de Campo.

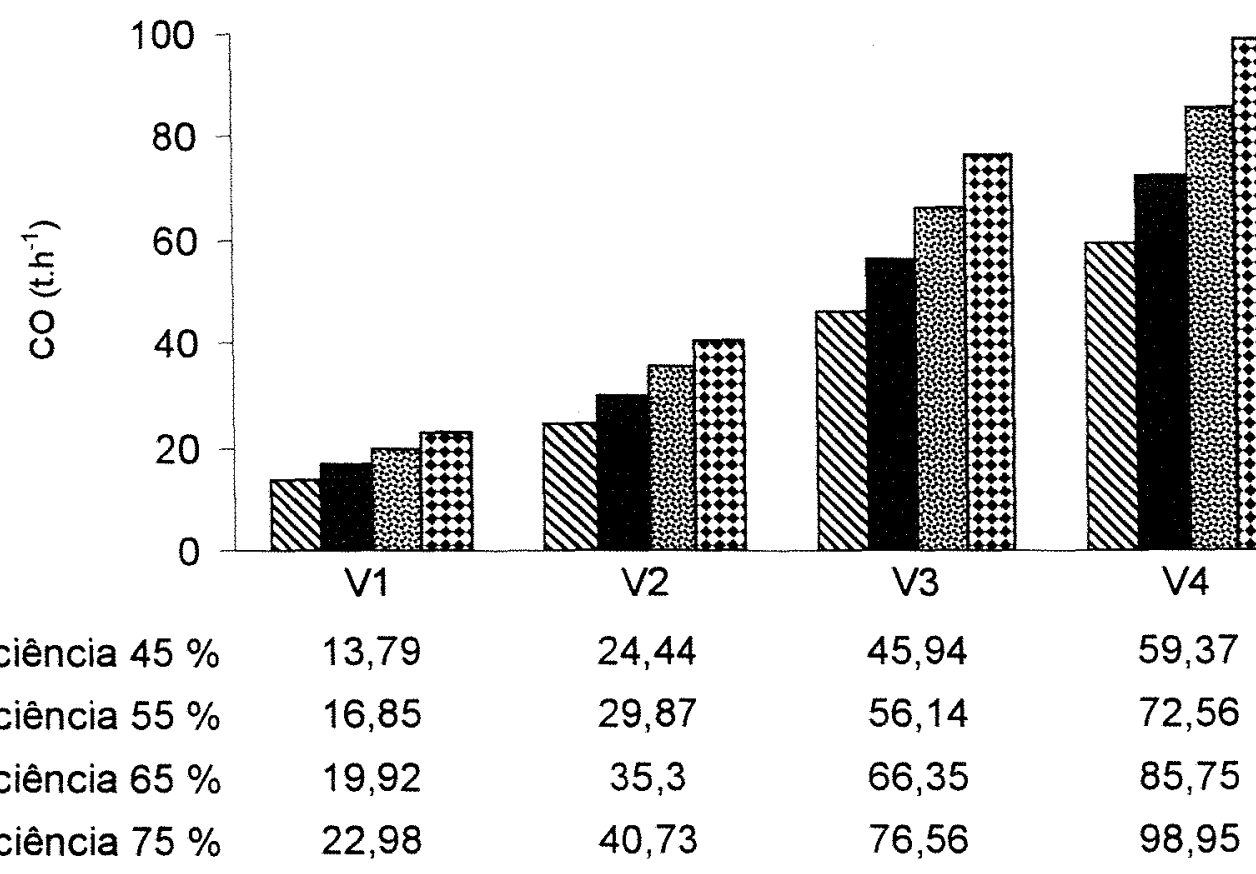

Figura 16. Resultados das Capacidades Operacionais em função das Eficiências de Campo estimadas de 45,55,65, $75 \%$, nas velocidades utilizadas. 
Observando-se a figura 16 , pode-se inferir que velocidades e Eficièncias de Campo muito baixas, resultam em baixas produtividades, fazendo com que a colhedora trabalhe com capacidades ociosas. Relatório interno da Usina Guarani (1996) apresenta, uma capacidade operacional média de $31,35 \mathrm{t} \cdot \mathrm{h}^{-1}$ numa eficiência global média de $42,26 \%$ com colhedora CC 2000 . Ripoli \& Mialhe (1982) verificaram uma média de capacidade operacional de 35,32 t.h $\mathrm{h}^{-1}$ como média de 50 colhedoras no estado de São Paulo. Novamente pode-se verificar que os dados de bibliografia, não contemplam metodologia padrão, neste caso a velocidade de trabalho que tem grande influência na capacidade operacional não é conhecida, dificultando uma comparação adequada de valores.

\subsubsection{Consumo de combustivel (CC)}

Analisou-se o consumo de combustivel em $1 . h^{-1}$ e $1 . \mathrm{t}^{-1}$. Observando-se a tabela 17 dos anexos e a figura 17, que a variável consumo de combustivel em $1 \cdot h^{-1}$, não apresentou diferenças significativas para as velocidades $V 1$ e V2. Houve diferenças significativas entre as velocidades $\mathrm{V} 1$ e $\mathrm{V} 2$ quando comparadas com as velocidades V3 e V4. Todos analisados através de teste de tukey ao nível de significância de $5 \%$.

108,45

$\mathrm{CC}\left(1 . \mathrm{h}^{-1}\right)$

103,90

97,35

96,22

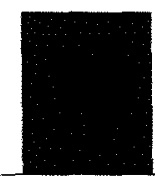

V1

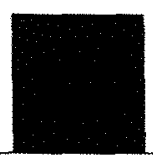

$\sqrt{2}$

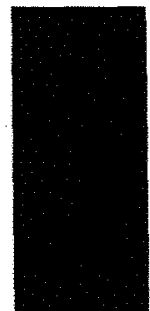

V3

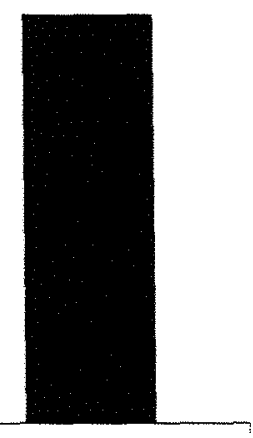

V4

Figura 17. Resultados do Consumo de Combustível em $1 . h^{-1}$, para as velocidades estudadas.

Pelos resultados obtidos, nota-se que o consumo de combustivel na velocidade 
$V 4$, foi de apenas $11,34 \%$ maior que o consumo na velocidade $V 1$, podendo inferir que o maior consumo de combustivel é dado pelos órgãos internos da colhedora que trabalham a rotação constante para todas velocidades, evidentemente que existe um esforço maior nestes órgãos conforme maior a quantidade de cana no mesmo tempo, ocorrido pelo aumento de velocidade de deslocamento da colhedora.

Pode-se inferir também que, a não existência de diferenças significativas para as velocidades $\mathrm{V} 1$ e $\mathrm{V} 2$, acontece pelo fato da carga ser muito baixa nestas velocidades.

O fabricante Brastoft (Case), apresenta em Boletim técnico (1998), da colhedora Brastoft A-7700, que a média em 29 Usinas na safra 97/98, do consumo de combustivel para seus modelos de colhedoras foi de $35,11 . \mathrm{h}^{-1}$.

Analisando o consumo de combustivel em $1 . \mathrm{t}^{-1}$, observa-se na tabela 19 dos anexos e a figura 18, que não houve diferenças significativas entre as velocidades $V 3 \mathrm{e}$ V4. Houve influência significativa para as velocidades V1 e V2 quando comparadas com as velocidades V3 e V4. Todos analisados através de teste de tukey ao nível de significância de $5 \%$.

3,21

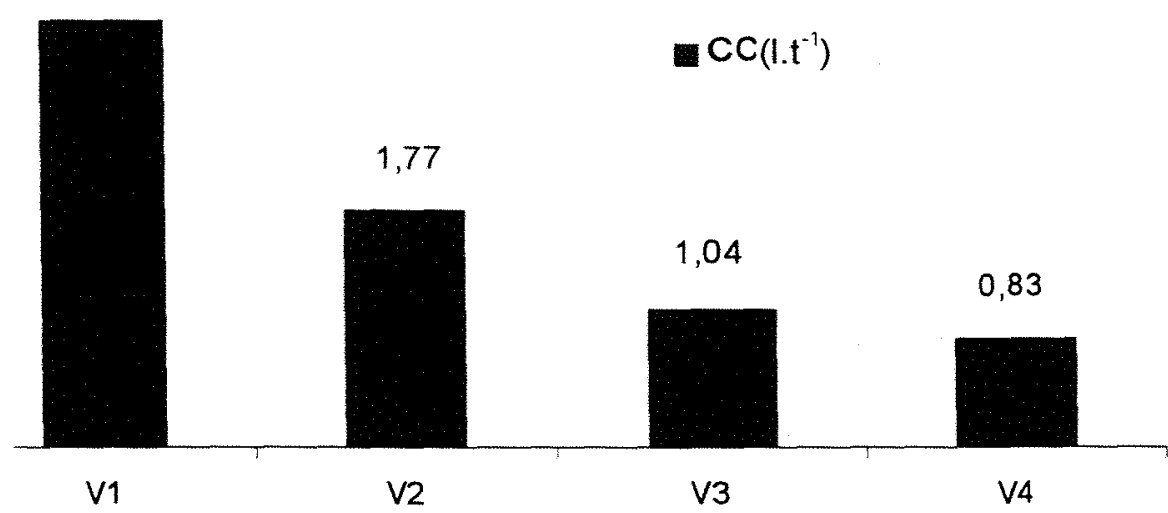

Figura 18. Resultados do Consumo de Combustível em $1 . \mathrm{f}^{-1}$, para as velocidades estudadas. 
Observa-se, pelos resultados obtidos, que o consumo de combustível em l.t- ${ }^{1}$, na velocidade $\mathrm{V} 4$, é $25,86 \%$ menor, praticamente $1 / 4$, que o Consumo na velocidade $V 1$, podendo inferir que mesmo o consumo de combustivel em $I . h^{-1}$ na velocidade $V 4$ ser maior, como nesta velocidade a colhedora colhe mais cana que nas outras velocidades, o consumo em I.t- ${ }^{1}$, cai bastante. Nota-se que será mais rentável, trabalhar na velocidade $\mathrm{V} 3$, pois se não existe diferença significativa para o consumo de combustivel em $1 . t^{-1}$ nas velocidades $\mathrm{V} 3$ e V4, por sua vez na velocidade V2 a colhedora apresenta menor consumo em I. $\mathrm{h}^{-1}$. O fabricante Brastoft (Case), apresenta em Boletim técnico de dados da colhedora Brastoft (1998), que a média estimada em 29 Usinas na safra 97/98, do consumo de combustivel para seus modelos de colhedoras foi de $1,12 \mathrm{l} \cdot \mathrm{t}^{-1}$. Lima (1998) apresenta valores que vão de 0,71 a $1,56 \mathrm{I} \cdot \mathrm{t}^{-1}$ para 5 marcas de colhedoras diferentes em todo Brasil. Romero et al. (1997) mostra valores de consumo com 29 colhedoras na Argentina variando de 0,9 a $1,61 . \mathrm{t}^{-1}$.

Baseado nessas informações, pode-se inferir que a colhedora deste estudo, apesar de consumir mais combustivel em $\mathrm{Ih}^{-1}$ que outras colhedoras, apresenta maior capacidade de colheita o que resulta em consumos muito semelhantes ou até menor em $1 . t^{-1}$. Pode-se observar também que, trabalhos em velocidades diferentes podem alterar significativamente os valores do Consumo efetivo $\left(1 . \mathrm{t}^{-1}\right)$, o que na falta de uma metodologia padronizada, pode apresentar resultados que não possibilitam uma comparação realistica entre colhedoras diferentes.

\subsection{Perdas e Qualidade da matéria-prima colhida}

\subsubsection{Perdas de matéria-prima no campo}

\subsubsection{Colmos e suas Frações (CF)}

A análise estatística dos resultados de Colmos e suas Frações, resultaram num coeficiente de variação muito alto, em torno de $300 \%$, o que inviabiliza esta análise. Os valores apresentados na tabela 21 dos anexos, e na figura 19 , servem de referência dos resultados obtidos no ensaio. 


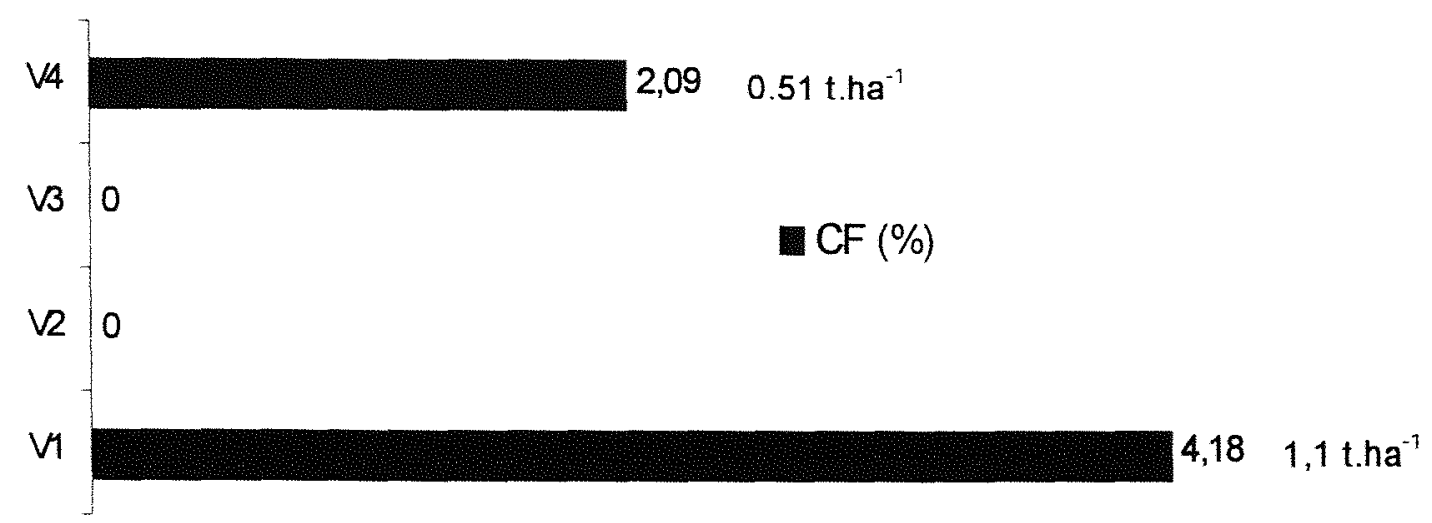

Figura 19. Resultados de Colmos e suas Frações deixadas no campo nas velocidades estudadas.

Observa-se que nas velocidades V2 e V3 não foram deixados, após a passagem da colhedora, colmos e suas frações no campo. Furlani Neto (1984) encontrou no corte manual uma perda de 2,76 tha $^{-1}$ de colmos e suas frações deixadas no campo. Peixoto \& Delgado (1988) encontraram 1,74 tha $^{-1}$ de colmos e sua frações na colheita manual. Baseado nos resultados obtidos, nota-se que a máquina não recolheu do terreno de 2 a $4 \%$ das Perdas deixadas no campo, de colmos e suas frações.

\subsubsection{Rebolos inteiros (RI)}

Pelos resultados obtidos conforme da tabela 23 dos anexos, as médias de rebolos inteiros deixados no campo após a passagem da colhedora não tiveram diferenças significativas das 4 velocidades dos ensaios, conforme teste de Tukey, ao nível de significância de $5 \%$. 


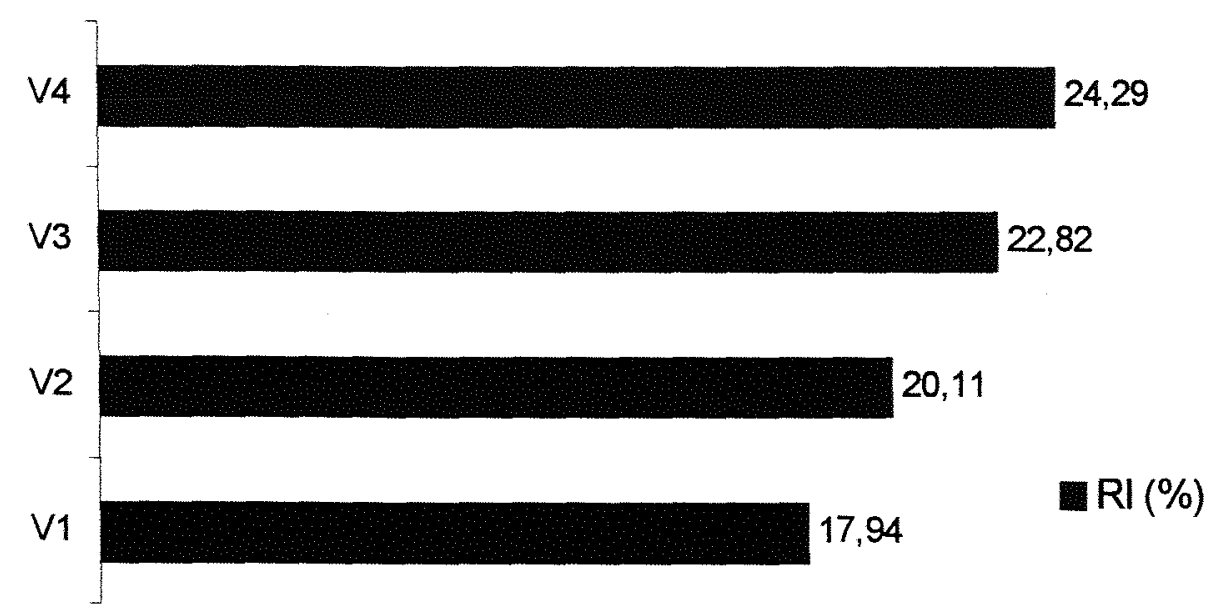

Figura 20. Percentagem de Rebolos Inteiros deixados no campo nas velocidades estudadas.

Observa-se um pequeno aumento do número de rebolos inteiros deixados no campo com o aumento da velocidade da colhedora, mas como já descrito, não significativo estatisticamente. Verifica-se que a máquina, deixou no campo em torno de $20 \%$ do total das perdas na forma de rebolos inteiros. Lima (1994) obteve percentual de Rebolos Inteiros deixados no campo de 14,12 e 31,60 com colhedoras Engeagro E6000 e E-8000 respectivamente.

\subsubsection{Frações de rebolos (RF)}

Observa-se, através da tabela 26 dos anexos, que as médias das frações de rebolos deixadas no campo após a passagem da colhedora não tiveram diferenças significativas das 4 velocidades, conforme teste de Tukey, ao nível de significância de $5 \%$. A figura 21 mostra os valores médios obtidos. 


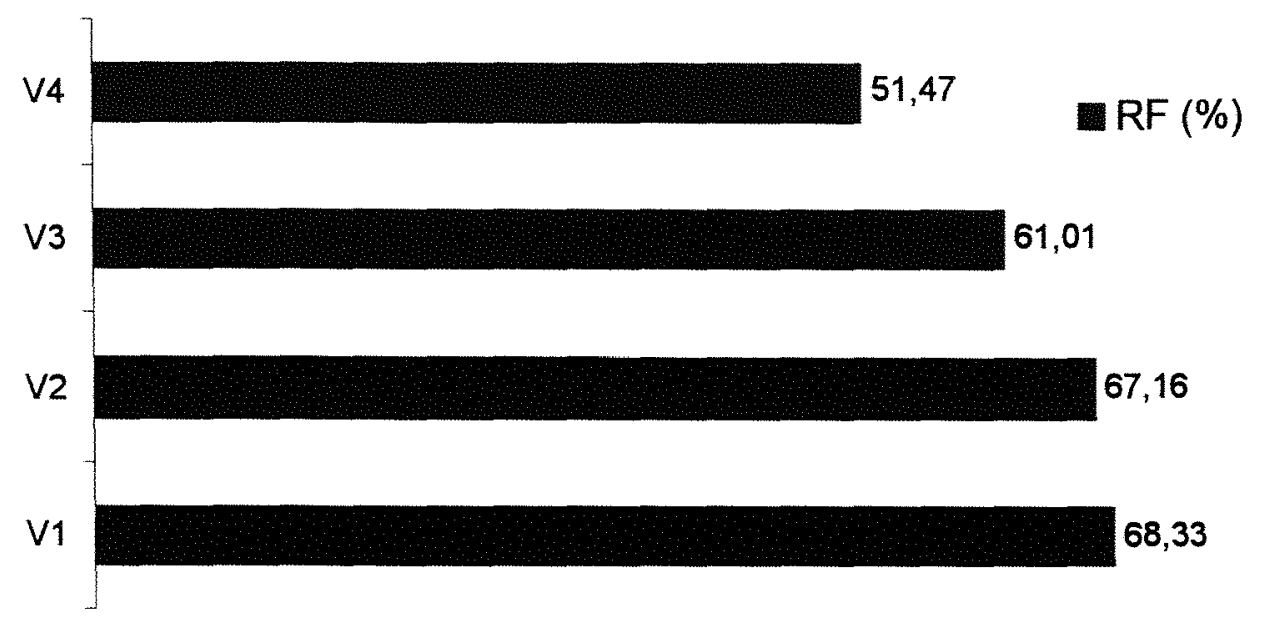

Figura 21. Percentagem de Frações de Rebolos deixados no campo nas velocidades estudadas.

Observa-se um pequeno aumento de frações de rebolos deixados no campo com a diminuição da velocidade da colhedora, mas como já descrito, não significativo estatisticamente. Nota-se que a máquina, deixa no campo frações de rebolos, em torno de $60 \%$ das perdas deixadas no campo. Pode-se inferir que o sistema de corte do colmo em rebolos, origina frações de colmos que é eliminado pelo sistema de limpeza, demonstrando que este sistema pode ser melhorado. Lima (1994) obteve percentual de Rebolos e suas Frações deixados no campo de 53,59 e 45,85 com colhedoras Engeagro E-6000 e E-8000 respectivamente.

\subsubsection{Rebolos na soqueira (RS)}

Observa-se, através da tabela 28 dos anexos, que as médias dos rebolos deixados na soqueira após a passagem da colhedora não tiveram diferenças significativas das 4 velocidades do ensaio, conforme teste de Tukey, ao nível de significância de 5\%. A figura 22 mostra os valores médios obtidos. 


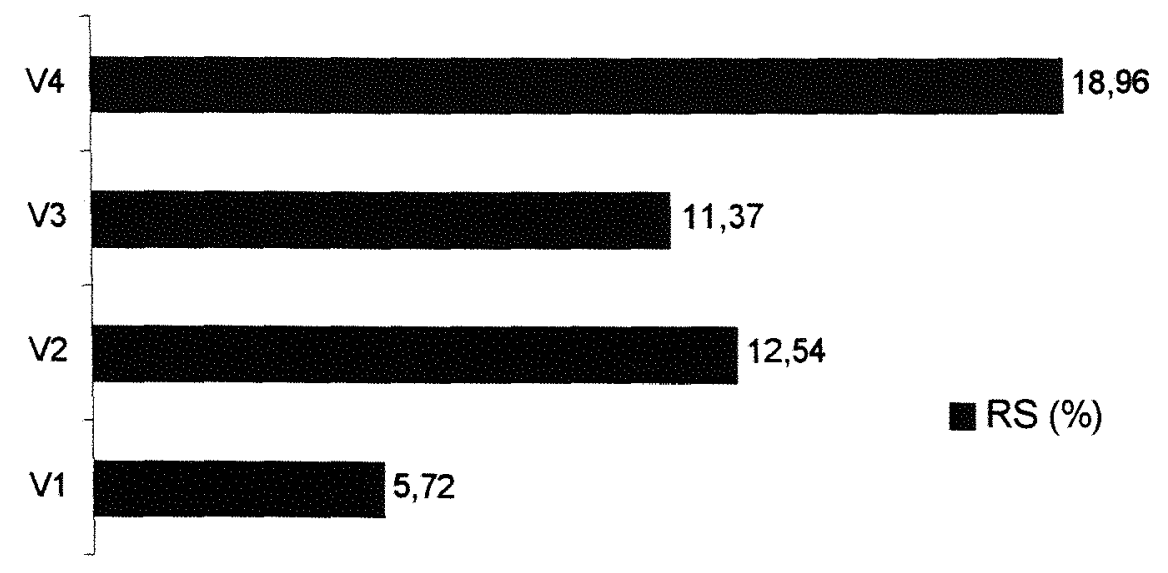

Figura 22. Percentagem de Rebolos na Soqueira nas velocidades estudadas.

Observa-se um pequeno aumento de rebolos na soqueira deixados no campo com o aumento da velocidade da colhedora, mas como já descrito, não significativo estatisticamente. A máquina, deixa no campo rebolos na soqueira, em torno de $12 \%$ das perdas deixadas no campo. Pode-se inferir que o sistema de corte basal, não sofre alteração significativa com colheita em velocidades diferentes, mas com a habilidade do operador da colhedora, na regulagem da altura do disco de corte basal. Lima (1994) obteve percentual de Rebolos na Soqueira de 21,98 e 17,35 com colhedoras Engeagro E-6000 e E-8000 respectivamente.

\subsubsection{Perdas totais deixadas no campo $\left(\mathrm{PT}_{\mathrm{c}}\right)$}

Observa-se através da tabela 32 dos anexos, que as perdas totais deixadas no campo após a passagem da colhedora tiveram diferenças significativas das 4 velocidades do ensaio, conforme teste de Tukey, ao nivel de significância de $5 \%$. A figura 23 mostra os valores médios obtidos. 


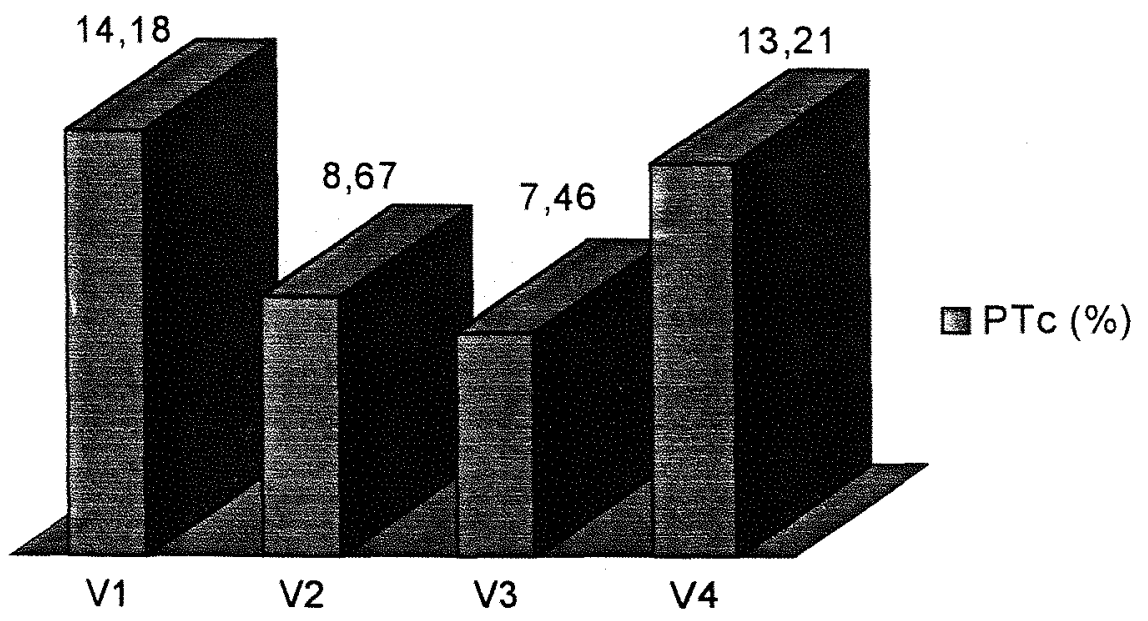

Figura 23. Percentagem de Perdas Totais deixadas no campo nas velocidades estudadas.

Observa-se que as menores Perdas Totais deixadas no campo ocorreram na velocidade $\mathrm{V} 3 \mathrm{e}$, quando comparado com $\circ$ Consumo de Combustivel em I. $\mathrm{t}^{-1}$, resulta na velocidade mais econômica com menor perdas. As perdas nas velocidades $\mathrm{V} 2$ e $\mathrm{V} 3$ estão muito próximas, assim como nas velocidades V1 e V4. Magro (1999) relata que a média de perdas total em cana crua na Austrália, colhida mecanicamente chega a 12 $\%$. Fernandes \& Irvine (1988) verificaram perdas totais de 18,3 \% para o corte mecanizado em cana crua. Mialhe \& Carraro Neto (1993) encontraram perdas totais de 3,22 e 4,14\% em velocidades de 3,67 e 4,04 km. $\mathrm{h}^{-1}$ respectivamente. Em relatório a Usina Guarani (1996) apresenta uma perda média de 6,56 \%. Furlani Neto (1996) encontrou perda total de $16,0 \%$. Romero et al. (1993) encontraram perdas que variaram de 2,8 a 7,2 em duas colhedoras diferentes em 6 variedades de cana diferentes. Baseado nos dados apresentados pode-se ver uma heterogeneidade de valores, demonstrando que a metodologia utilizada para o levantamento de parâmetros e a definição dos próprios parâmetros não obedece a uma padronização efetiva.

\subsubsection{Qualidade da matéria-prima colhida}

\subsubsection{1 Índice de Ponteiros (IP)}


Observa-se através da tabela 34 dos anexos que as médias, do índice de ponteiros, contidas na matéria-prima não tiveram diferenças significativas das 4 velocidades do ensaio, conforme teste de Tukey, ao nivel de significância de $5 \%$. A figura 24 mostra os valores médios obtidos.

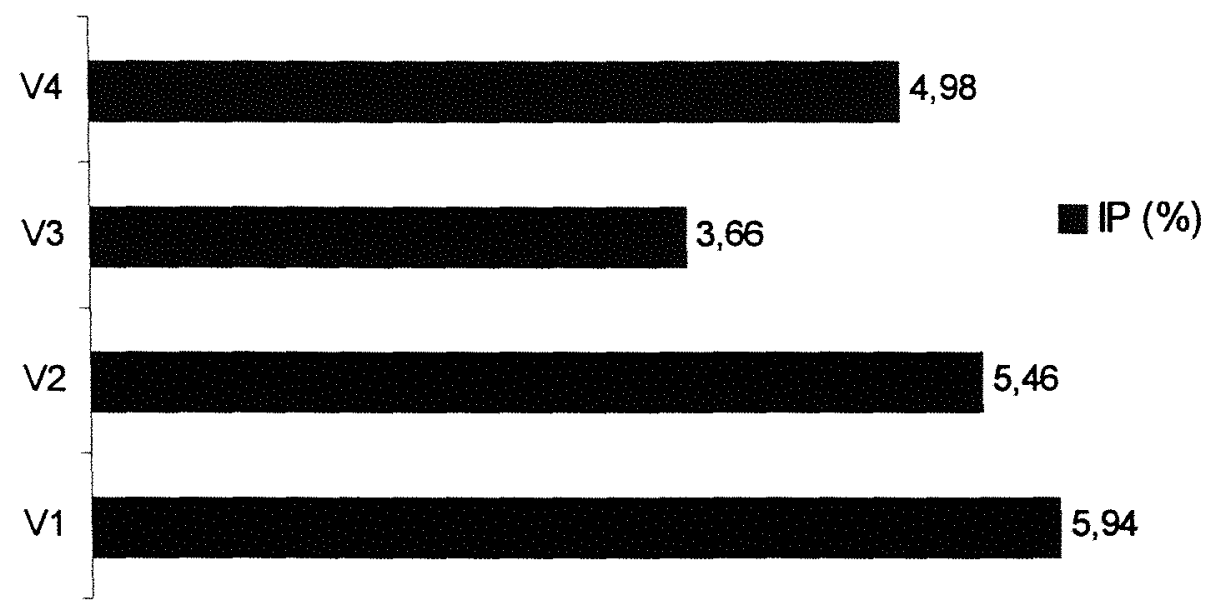

Figura 24. Resultados médios dos Índices de Ponteiros contidos na matériaprima, no veículo de transporte para as 4 velocidades estudadas.

O Índice de Ponteiros apresenta-se com valores que variaram em média de $5,01 \%$. Considera-se este valor, de Ponteiros soltos ou agregados a colmos de toda carga no veículo de transporte, um valor alto, podendo-se inferir que este alto índice ocorreu por que o ensaio foi realizado com o despontador desligado. Furlani Neto et al. (1996) obtiveram percentual de índice de Ponteiros de 9,0 com colhedora Santal Amazón na região de Ribeirão Preto. Ripoli \& Ripoli (1996) obtiveram percentuais de Índice de ponteiros de 5,91 para SP801842 e 4,32 para RB72454, na região de Piracicaba.

\subsubsection{2 İndice de Folhas Verdes $\left(\mathrm{IF}_{\mathrm{v}}\right)$}

Observa-se, através da tabela 36 dos anexos, que as médias do índice de Folhas Verdes contido na matéria-prima, não tiveram diferenças significativas das 4 velocidades do ensaio, conforme teste de Tukey, ao nivel de significância de $5 \%$. A figura 25 mostra os valores médios obtidos. 


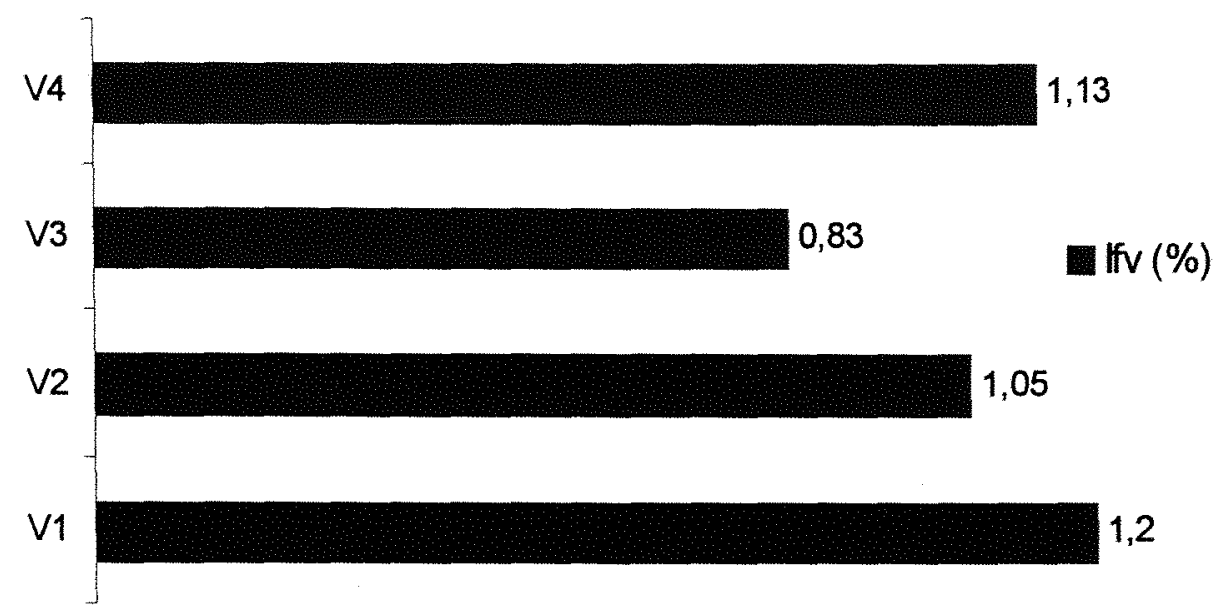

Figura 25. Resultados médios do Índice de Folhas Verdes contidas na matériaprima, no veículo de transporte, para as 4 velocidades estudadas.

Os valores variaram em torno de 1,0\%. Pode-se inferir que o mecanismo de processamento e limpeza da matéria-prima, não sofreu interferência da velocidade de deslocamento da colhedora. Fernandes \& Irvine (1986) obtiveram em corte mecanizado, um índice de $6,0 \%$ de folhas contidas na carga. Nota-se que, pela não atuação do despontador no ensaio, folhas verdes aderidas ao ponteiro provavelmente não foram retiradas com eficiência, pois os diâmetros dos ponteiros por serem bem menor que os colmos, não sofreram uma eficiente desfolha pelo mecanismo da máquina.

\subsubsection{3 Índice de palhas $\left(\mathrm{IP}_{\mathrm{a}}\right)$}

Observa-se através da tabela 38 dos anexos, que as médias do Índice de Palhas contida na matéria-prima tiveram diferenças significativas das 4 velocidades do ensaio, conforme teste de Tukey, ao nivel de significância de 5\%. A figura 26 mostra os valores médios obtidos. 


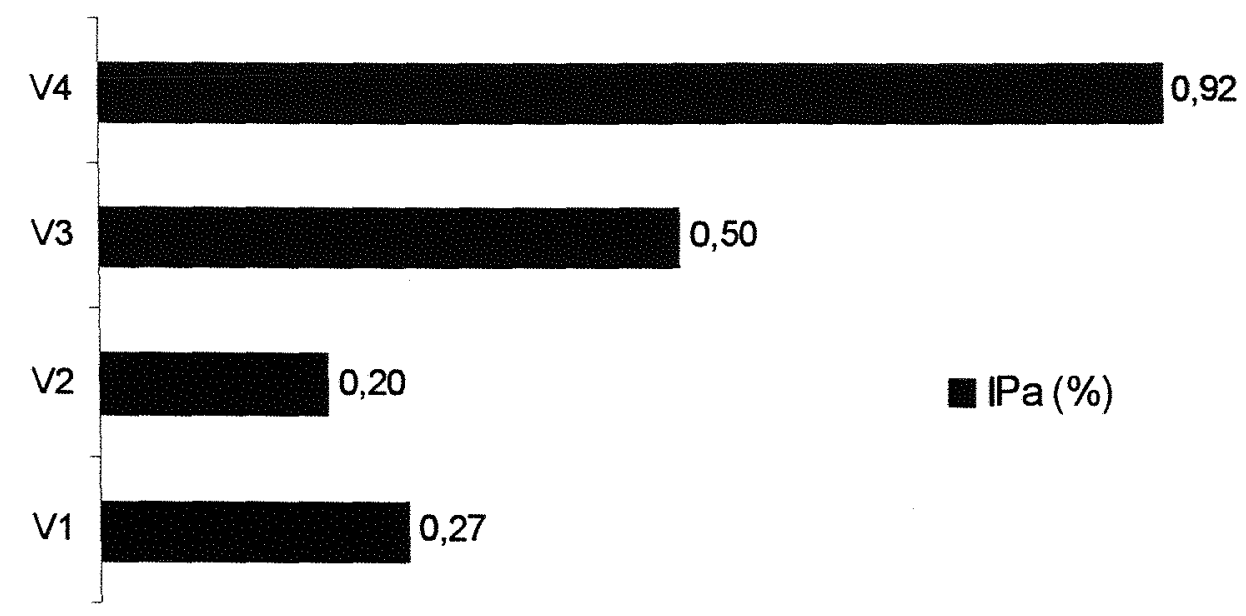

Figura 26. Resultados médios dos Índices de Palhas contidas na matéria-prima, no veículo de transporte. Dara as 4 velocidades estudadas.

Observa-se que o Índice de Palhas apresentou diferenças significativas entre a velocidade mais baixa $\mathrm{V} 1$ e a mais alta $\mathrm{V} 4$, resultando em valores que variaram de 0,27 a $0,92 \%$. Pode-se inferir que o mecanismo de processamento e limpeza da matéria prima, sofreu pequena interferência da velocidade de deslocamento da colhedora. Herrera \& Linares (1986), estudando colhedora KTP-1, encontraram Índice de Palhas de $2,0 \%$ em canavial sem queima prévia, mas não relatam a velocidade de colheita no estudo.

\subsubsection{4 Índice de Raízes (IR)}

Observa-se, através da tabela 40 dos anexos, que as médias do índice de Raizes contido na matéria-prima, não tiveram diferenças significativas das 4 velocidades estudadas, conforme teste de Tukey, ao nivel de significância de $5 \%$. A figura 27 mostra os valores médios obtidos. 


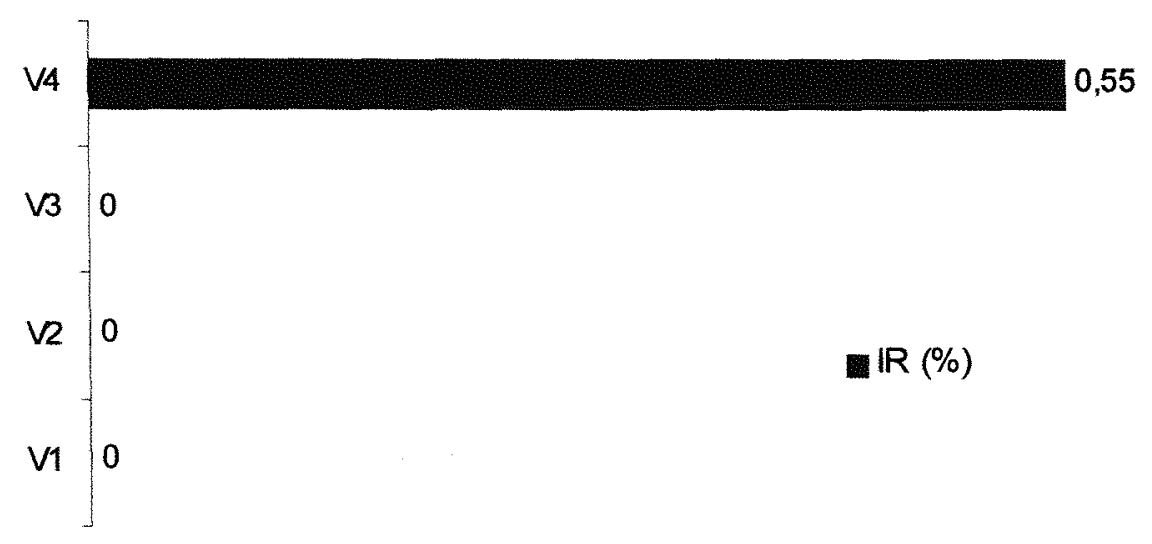

Figura 27. Resultados médios dos Índices de Raízes contidas na matériaprima, no veículo de transporte para as 4 velocidades estudadas.

Na maior velocidade V4, houve a presença de aproximadamente $0,5 \%$ de raizes, o que mostra aparentemente, que em alta velocidade de deslocamento da máquina, tanto o operador da máquina quanto o dispositivo de contorno do terreno que mantém a constância de altura de corte basal (patins deslizantes), não conseguiu manter uma melhor performance de trabalho. Furlani Neto (1984) obteve percentual de Raizes arrancadas de 0,2.

\subsubsection{Raízes arrancadas (RT)}

Observa-se, através da tabela 30 dos anexos, que as raizes arrancadas após a passagem da colhedora não sofreram influências significativas das 4 velocidades estudadas, conforme teste de Tukey, ao nível de significância de $5 \%$. A figura 28 mostra os valores médios obtidos. 


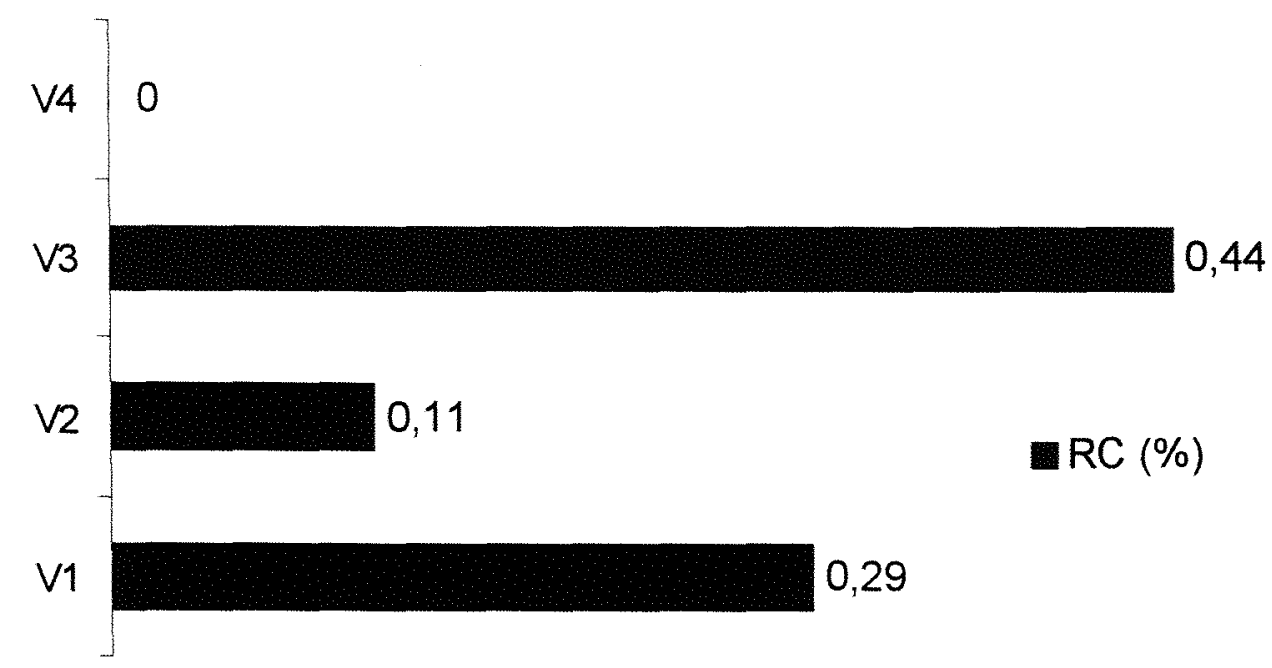

Figura 28. Percentagem de Raízes arrancadas nas velocidades estudadas.

Observa-se que na velocidade maior V4, não houve arrancamento de raízes. Pode-se inferir que o sistema de corte basal, não sofre alteração significativa com colheita em velocidades deferentes, mas com a habilidade do operador da colhedora na pré-regulagem da altura do disco de corte basal, que se mal regulado, poderá cortar raizes da soqueira comprometendo a próxima brotação.

\subsubsection{6 Índice de Matéria Estranha Vegetal (IV)}

Observa-se, através da tabela 42 dos anexos, que as médias do índice de Matéria Estranha Vegetal contida na matéria-prima, no veículo de transporte, não tiveram diferença significativa das 4 velocidades estudadas, conforme teste de Tukey, ao nível de significância de $5 \%$. A figura 29 mostra os valores médios obtidos. 


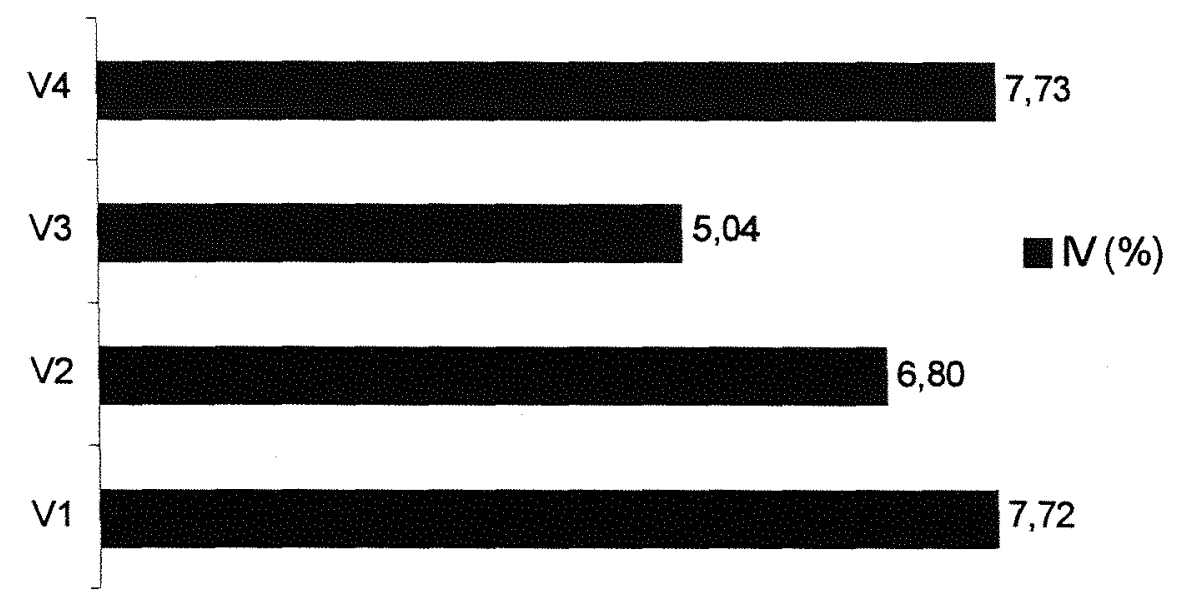

Figura 29. Resultados médios dos Índices de Matéria Estranha Vegetal contida na matéria-prima, no veículo de transporte para as 4 velocidades estudadas.

Observa-se que o menor Índice de Matéria Estranha Vegetal contida na matéria-prima, no veículo de transporte ocorreu na velocidade $V 3$, embora não tenha existido diferença significativa entre as demais velocidades. Fernandes \& Oliveira (1977) relatam que para a colheita mecânica nas safras 1974/75 e 1976/77, a média de Matéria Estranha Vegetal foi de 15,0 \%. Peixoto \& Delgado (1988) verificaram para as safras de 1985, Índice de Matéria Estranha Vegetal de 4,02 \%. Morais \& Neves (1997) encontraram 9,9\% no IV. Nunes Júnior \& Pinto (1999) apresentam uma expectativa para a safra $1998 / 99$ um IV de $6,6 \%$ na cana crua, em Usinas do Centro-Sul do Brasil. Vários autores mostraram este Indice, conforme quadro 4, do item 2.11, valores que vão de $3,93 \%$ a $10,0 \%$. Baseado nos dados apresentados pode-se ver uma heterogeneidade de valores, demonstrando que a metodologia utilizada para o levantamento de parâmetros e a definição dos próprios parâmetros não obedece a uma padronização efetiva. Mas mesmo com esta heterogeneidade, pode-se observar que máquinas modernas, não diferem muito de valores obtidos com máquinas mais antigas, demonstrando que ou as máquinas não tiveram uma grande evolução nestes últimos anos ou, este índice não depende fortemente da máquina, mas de outros fatores, como variedade e qualificação do operador. 


\subsubsection{7 Índice de Matéria Estranha Mineral (IM)}

A análise estatística dos resultados do indice de Matéria Estranha Mineral, resultou num coeficiente de variação muito alto, em torno de $290 \%$, o que inviabiliza esta análise. Os valores apresentados na tabela 44 dos anexos, e na figura 30 , servem de referência dos resultados obtidos no ensaio.

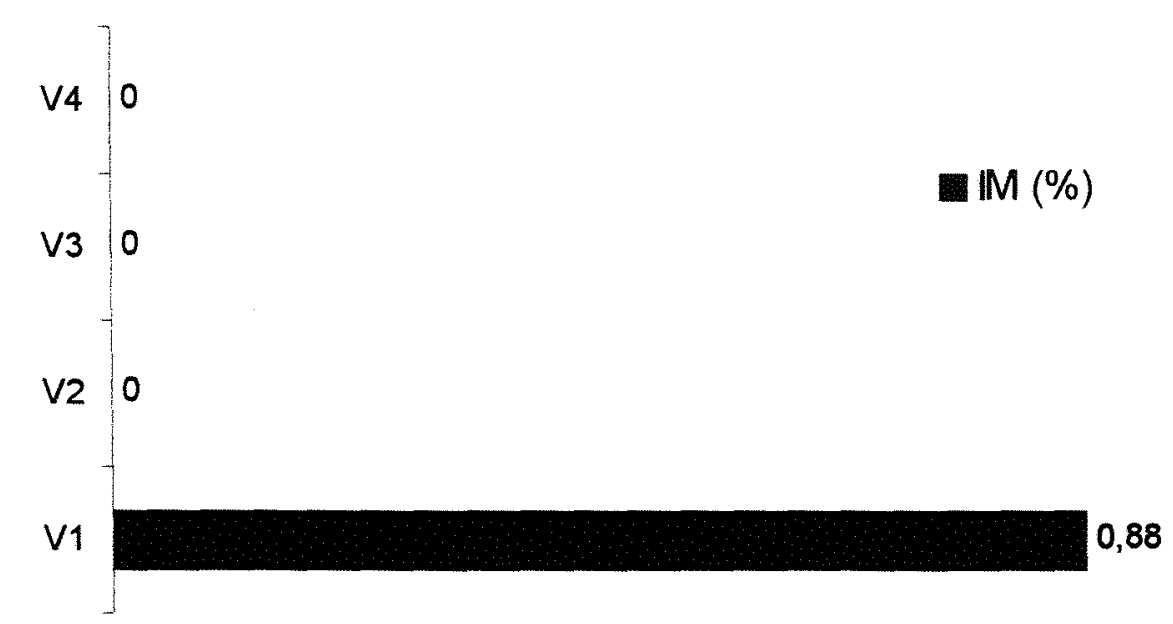

Figura 30. Resultados médios do Índice de Matéria Estranha Mineral contida na matéria-prima, no veículo de transporte nas 4 velocidades estudadas.

Observa-se que não foi encontrada terra/solo na matéria-prima, no veiculo de transporte nas velocidades $V 2, V 3$ e $V 4$, apenas na velocidade mais baixa $V 1$, demonstrando que houve uma boa performance do sistema de limpeza da máquina para este item. Peixoto \& Delgado (1988) verificaram para as safras de 1985, índice de Matéria Estranha Mineral de 0,61 \%. Morais \& Neves (1997) encontraram 0,3\% no IM. Nunes Júnior \& Pinto (1999) apresentam uma expectativa para a safra 1998/99 um IM de $1,10 \%$ na cana crua, em Usinas do Centro-Sul do Brasil. Vários autores mostram este Índice, conforme quadro 4 , do item 2.11 , valores que vão de $0,1 \%$ a $0,83 \%$. Os valores encontrados são coerentes com os valores encontrados na bibliografia, levando-se em conta as diferentes formas de metodologias e condiçōes de trabalho para a coleta deste índice. 


\subsubsection{8 Índice de Matéria Estranha Total (IT)}

Observa-se, através da tabela 46, dos anexos, que as médias do índice de Matéria Estranha Total contida na matéria-prima, no veículo de transporte, não tiveram diferenças significativas das 4 velocidades estudadas, conforme teste de Tukey, ao nível de significância de $5 \%$. A figura 31 mostra os valores médios obtidos.

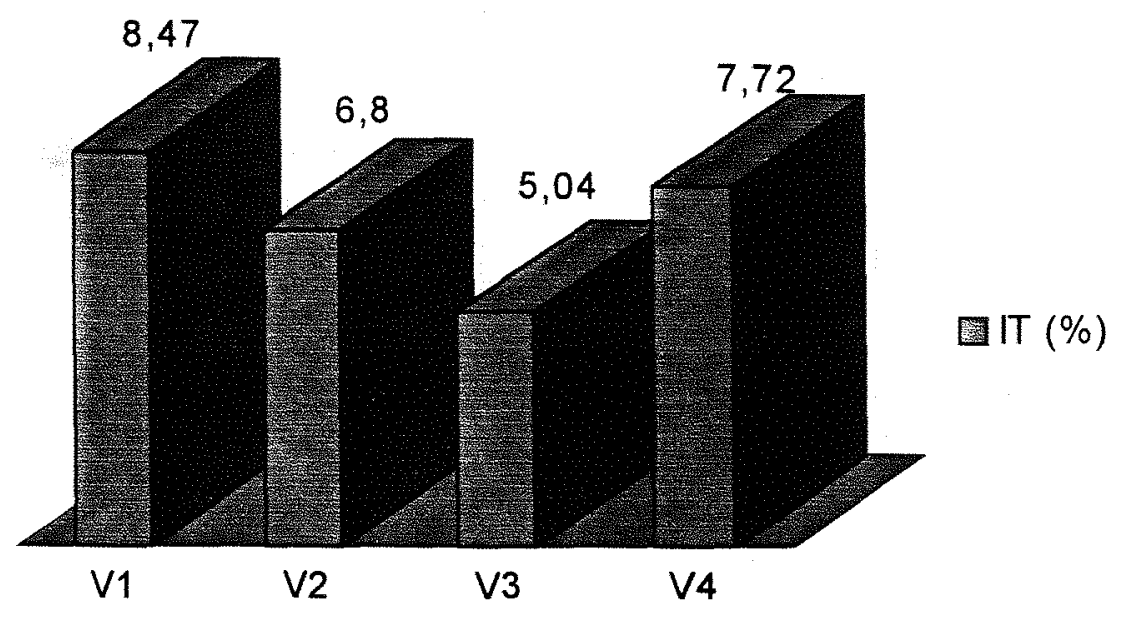

Figura 31. Resultados médios do Índice de Matéria Estranha Total contida na matéria-prima, no veículo de transporte nas 4 velocidades estudadas.

Observa-se que o menor Índice de Matéria Estranha Total contida na matériaprima, no veículo de transporte ocorreu na velocidade $V 3$. Nota-se pelas figuras 18 e 23 , que o consumo de combustível $1 . \mathrm{t}^{-1}$ à velocidade $\mathrm{V} 3$ é a mais econômica com menos Perdas no Campo e com menor Índice de Matéria Estranha Total recolhida no veículo de transporte. Peixoto \& Delgado (1988) verificaram Matéria Estranha total 5,45 $\%$ para o corte mecanizado, na safra de 1985. Nunes Júnior \& Pinto (1999) apresentam uma expectativa para a safra $1998 / 99$ um IT de $7,7 \%$ na cana crua, em Usinas do Centro-Sul do Brasil. Vários autores mostram este índice, conforme quadro 4 , do item 2.11, valores que vão de $4,2 \%$ a 10,5\%. Baseado nos dados apresentados pode-se inferir que os valores encontrados neste trabalho estão próximos a média encontrada pela bibliografia, e que pela diversidade de máquinas e condições de ensaio da bibliografia, podemos concluir que é difícil dizer qual máquina possui melhor interação Corte-Limpeza-Índíce de Matéria Estranha Total, pela pouca diferença entre os valores encontrados. 


\subsubsection{Qualidade Tecnológica da matéria-prima}

\subsection{Resultados de Brix, Pol, Pureza do caldo}

Observa-se, através das tabelas 48,50 e 52 dos anexos, que as médias dos parâmetros da qualidade tecnológica da matéria-prima Brix, Pol e Pureza do caldo após a colheita pela máquina, não tiveram diferença significativa das 4 velocidades estudadas, conforme teste de Tukey, ao nível de significância de $5 \%$. A figura 32 mostra os valores médios obtidos.

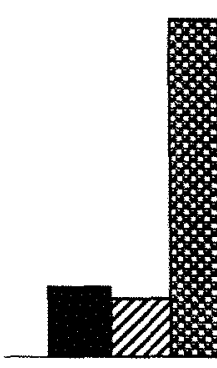

VI

17,27

14,22

82,22

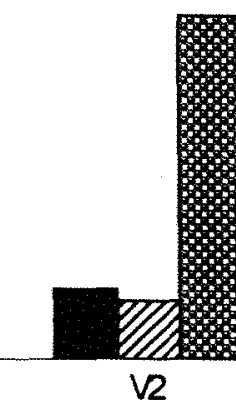

17,02

14,24

83,67

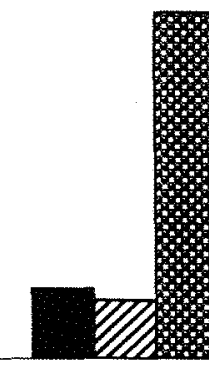

V3

17,12

14,4

84,07

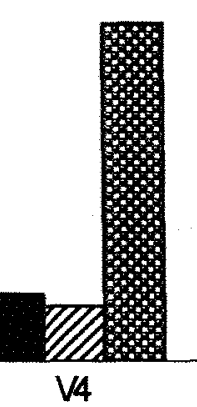

16,55

13,61

82,18

Figura 32. Resultados médios dos parâmetros da Qualidade tecnológica da matéria prima. \% do caldo. nas 4 velocidades ensaiadas.

Comparando os parâmetros Brix e Pol \% do caldo, da matéria-prima que foi colhida pela máquina e os respectivos valores, encontrados na matéria-prima do canavial antes da passagem da máquina, apresentados na tabela 4 dos anexos e figura 9 , pode se ver que a diferença é de aproximadamente $1,0 \%$ de perda, após a colheita pela máquina. Levando em consideração a variação estatística destes parâmetros, a colhedora não teve influência significativa na qualidade da matéria prima. 


\subsection{Resultados de Fibra, Pol, Terra da cana}

Observa-se, através das tabelas 54, 56 e 58 dos anexos, que as médias dos parâmetros da qualidade tecnológica da matéria-prima Fibra, Pol e Terra da cana após a colheita pela máquina, não tiveram diferença significativa das 4 velocidades ensaiadas, conforme teste de Tukey, ao nivel de significância de $5 \%$. A figura 33 mostra os valores médios obtidos.
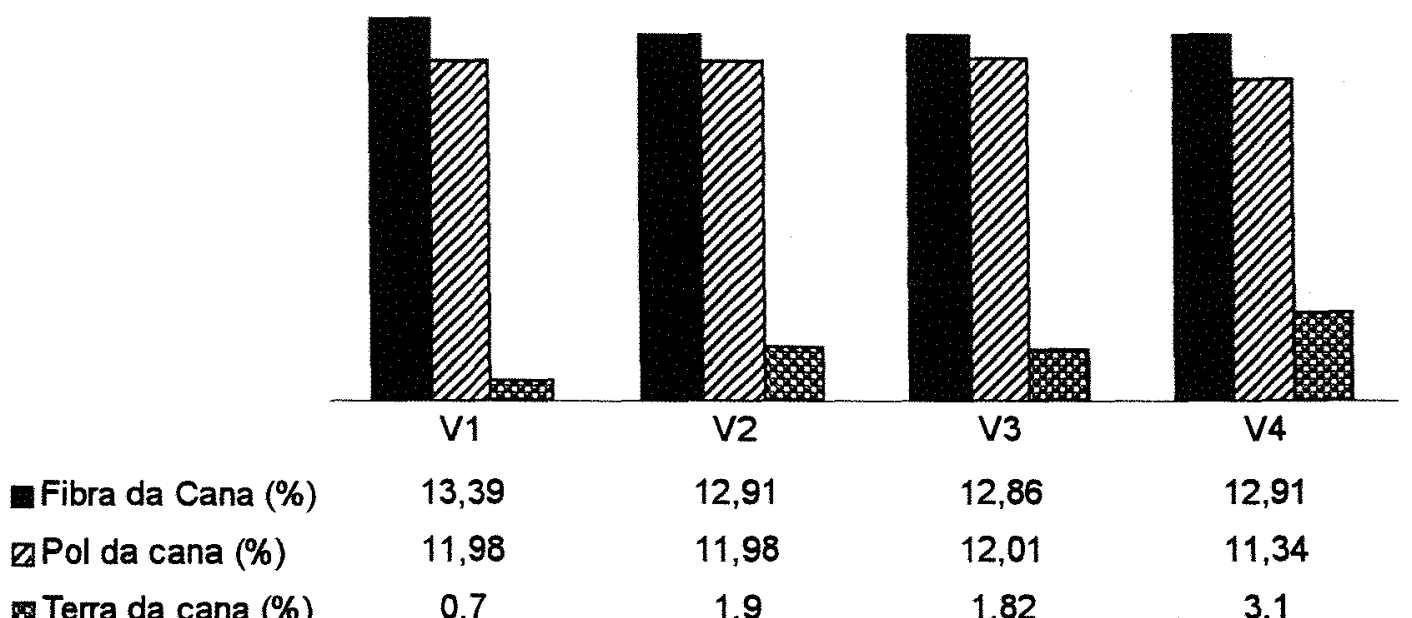

13,39

12,91

12,86

12,91

Terra da cana (\%)

11,98

11,98

12,01

11,34

0,7

1,9

1,82

3,1

Figura 33. Resultados médios dos parâmetros da Qualidade tecnológica da matéria prima, \% da cana, nas 4 velocidades ensaiadas.

Comparando a variável Fibra da Cana na matéria-prima que foi colhida pela máquina e os respectivos valores nela, encontrados no canavial antes da passagem da máquina, apresentado na tabela 4 dos anexos e figura 9 , pode-se observar, que a diferença é de aproximadamente $3,0 \%$ de perda, após a colheita pela máquina. Como era de se esperar o corte dos rebolos e as freqüentes colisões sofridas pelos rebolos ao longo de sua trajetória na colheita e carregamento provoca uma pequena diminuição do teor de fibra. Observa-se que o teor de terra da cana aumenta conforme o aumento da velocidade de deslocamento da colhedora, indicando que provavelmente a terra em forma de poeira teria se agregado às superficies dos rebolos no momento do corte do colmo em rebolos. 


\subsubsection{Freqüência de Comprimento dos rebolos}

Verifica-se, através das figuras $34,35,36$ e 37 , as Freqüências de Comprimento dos rebolos para as 4 velocidades ensaiadas.

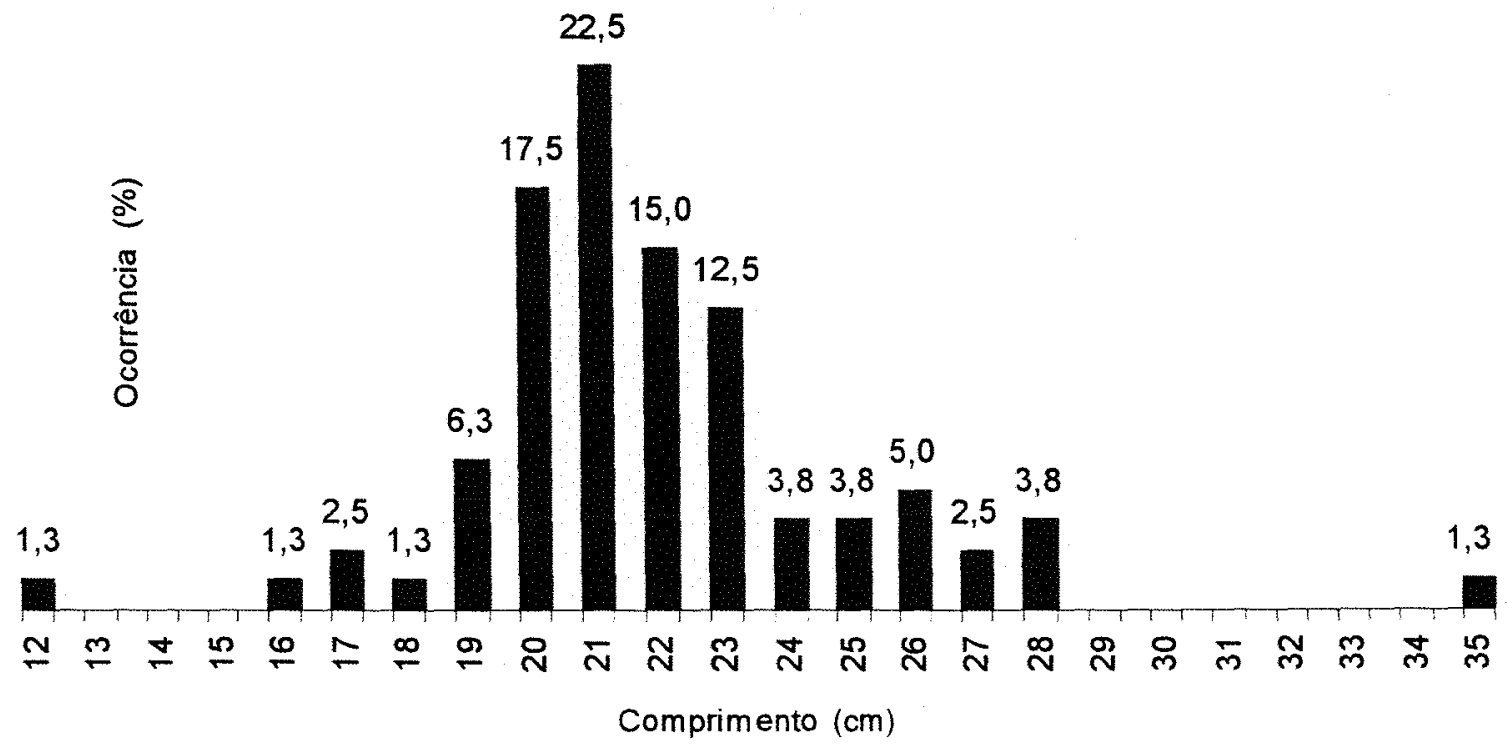

Figura 34. Freqüência de Comprimento dos rebolos na velocidade de ensaio V1.

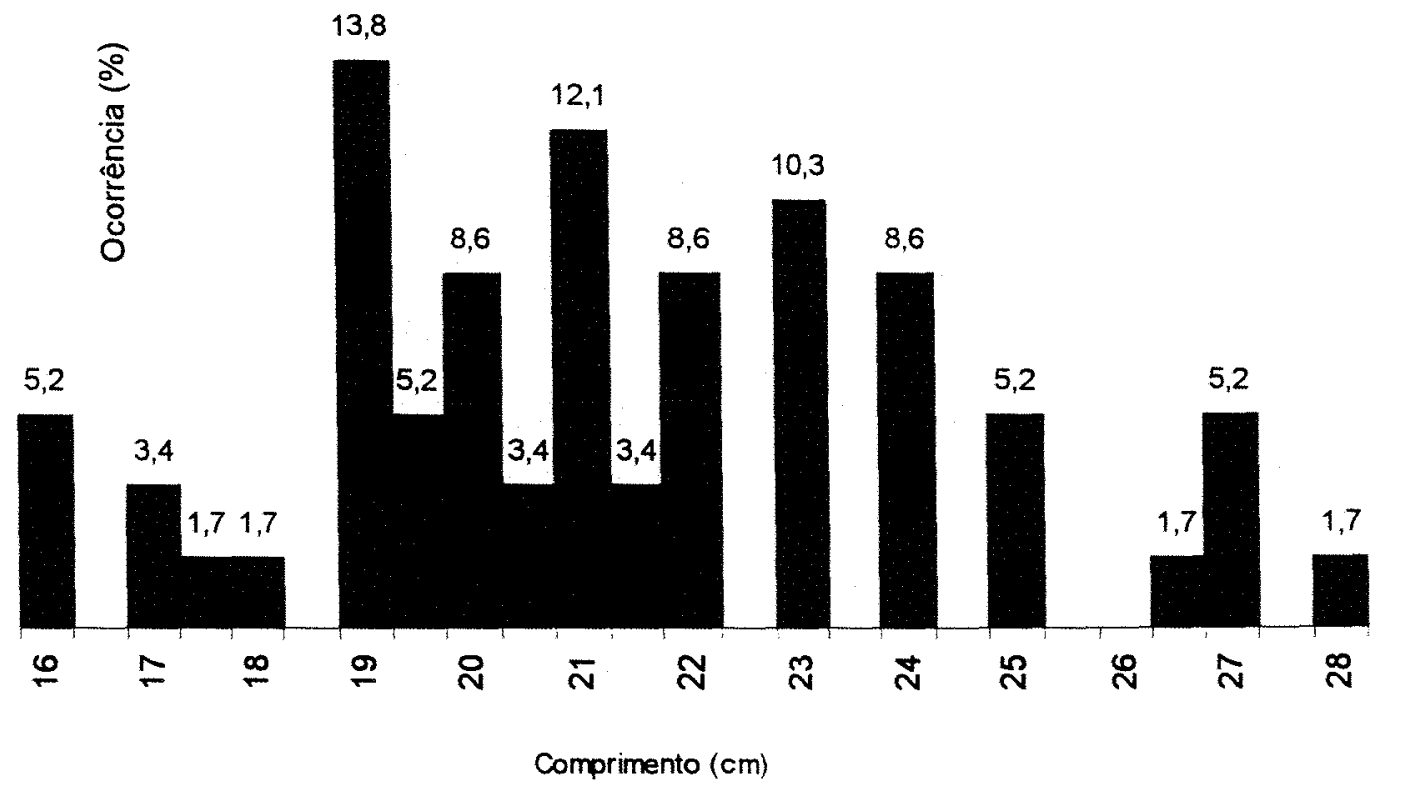

Figura 35. Freqüência de comprimento dos rebolos na velocidade de ensaio V2. 


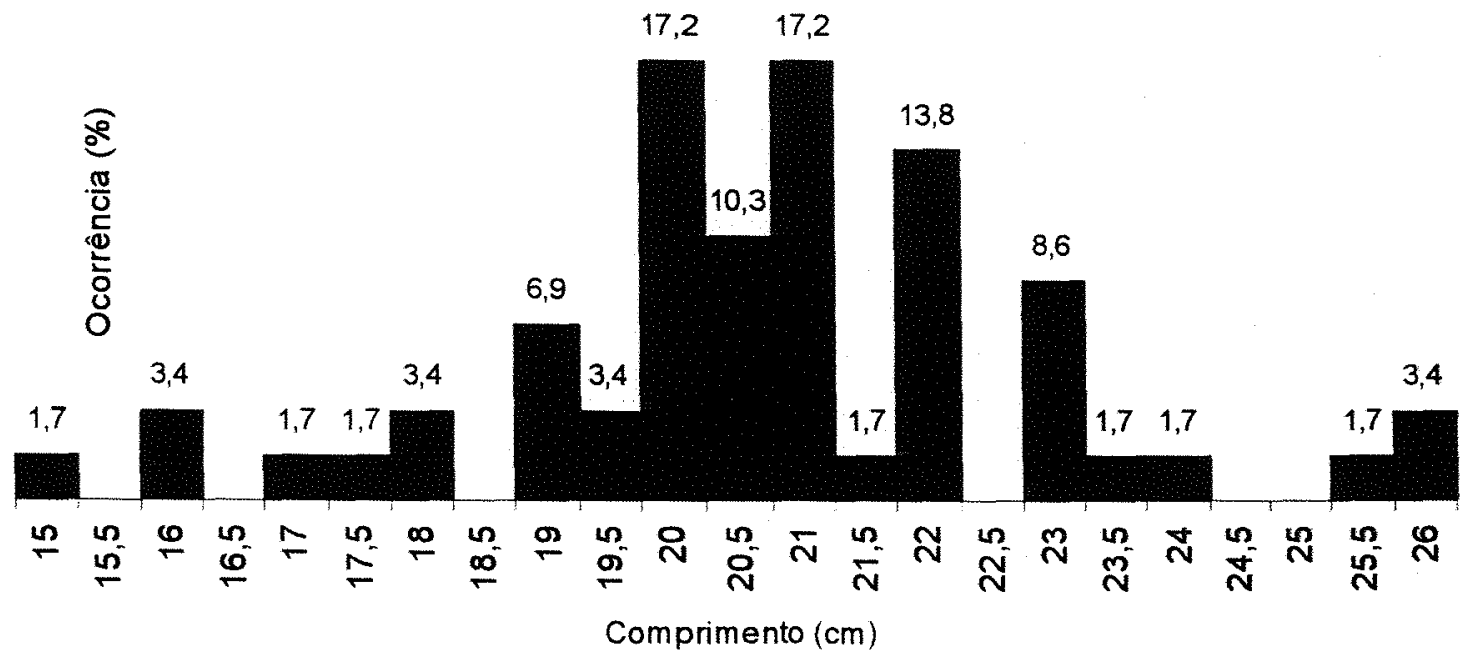

Figura 36. Freqüência de comprimento dos rebolos na velocidade de ensaio V3.

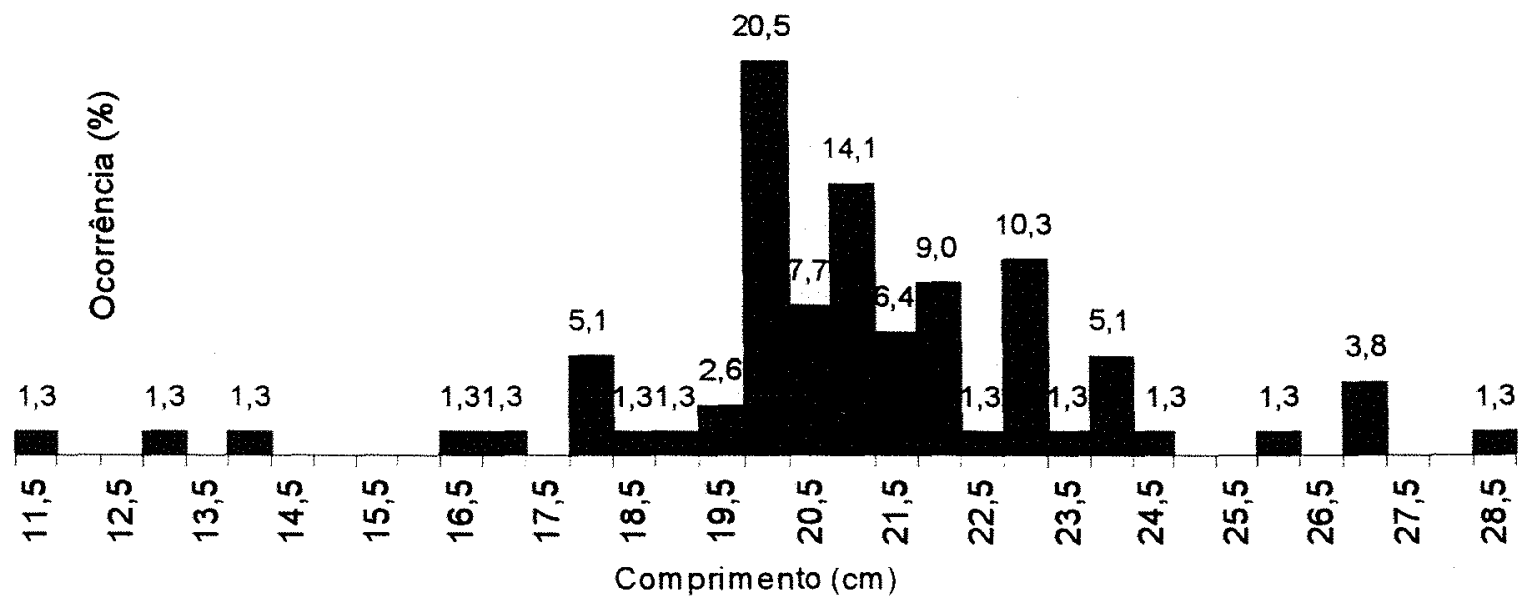

Figura 37. Freqüência de comprimento dos rebolos na velocidade de ensaio V4. 
Baseado nos resultados obtidos, nota-se que para comprimentos de rebolos variando de 19 a $26 \mathrm{~cm}$, encontram-se $86,4 \%$ para a velocidade $\mathrm{V} 1,79,2 \%$ para a velocidade V2, 85,9 e 82,2\% para as velocidades V3 e V4 respectivamente. Nota-se que a distribuição das freqüências dos tamanhos dos rebolos estão dispersas, induzindo a inferir que, a embreagem do sistema picador de colmos, como descrito no item 3.1.1.2.d, não estava atuando direito, deslizando durante a picagem dos colmos. Baseado nestes dados pode-se inferir que na velocidade $V_{1}$ houve uma menor variabilidade de tamanhos de rebolos, apesar de não ter havido diferença significativa para a velocidade V3. Nestas porcentagens, houve uma variação de $7 \mathrm{~cm}$ no comprimento dos rebolos, teoricamente não comprometendo o intervalo de variação permitido por um dosador de uma plantadora de rebolos de cana. Dependendo do tamanho dos rebolos, segundo cada variedade, existe a possibilidade de haver uma desuniformidade da quantidade de gemas nos rebolos oriundos dessa colhedora, podendo teoricamente originar uma porcentagem de brotação não uniforme se utilizado estes rebolos como cana planta.

\subsubsection{1 Índice de Cisalhamento dos rebolos}

Verifica-se, através das figuras $38,39,40$ e 41, os Índices de Cisalhamento dos rebolos para as 4 velocidades ensaiadas.

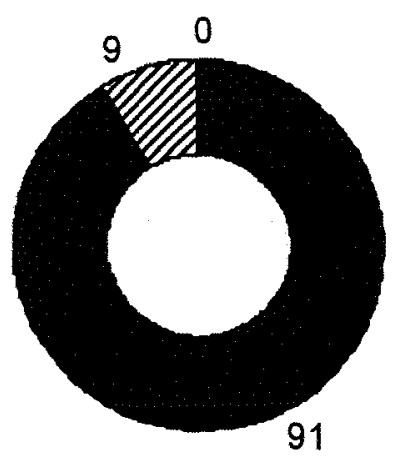

$(\%)$

- Perfeito

Macerado 1 lado

图 Macerado 2 lados

Figura 38. Percentual do Cisalhamento dos rebolos na velocidade de ensaio $\mathrm{V} 1$. 


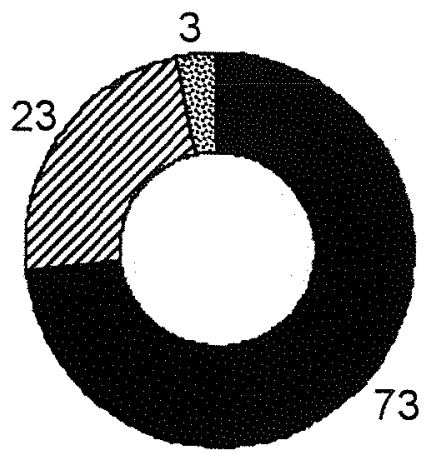
(\%)
Perfeito
Zacerado 1 lado
Macerado 2 lados

Figura 39. Percentual do Cisalhamento dos rebolos na velocidade de ensaio V2.

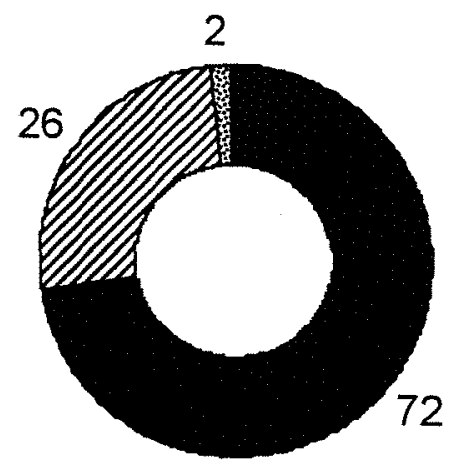

\section{$(\%)$}

Eerfeito

Macerado 1 lado

Macerado 2 lados

Figura 40. Percentual do Cisalhamento dos rebolos na velocidade de ensaio V3. 


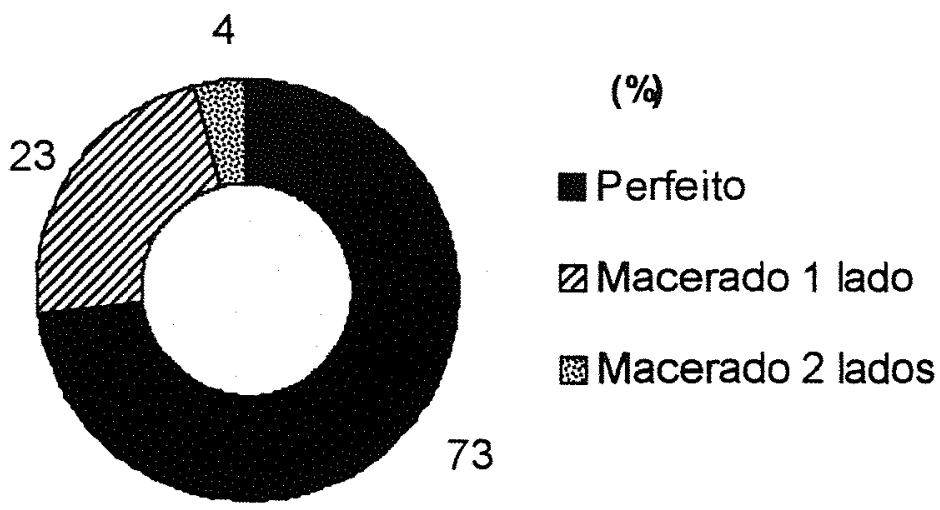

Figura 41. Percentual do Cisalhamento dos rebolos na velocidade de ensaio V4.

Pelos resultados obtidos, observa-se, que para a velocidade V1, ocorreu um menor índice de cisalhamento de rebolos. Para as velocidades V2, V3 e V4 não houve diferença significativa entre este indice, mostrando que o sincronismo do mecanismo de corte dos rebolos não foi alterado pela velocidade de deslocamento da máquina. Para a velocidade $V 1$, houve um melhor sincronismo entre o mecanismo de corte dos rebolos e a velocidade de deslocamento. Pode-se dizer que em todas as velocidades, não houve uma ótima performance de cisalhamento dos rebolos, conforme Ripoli (1996), que afirma que uma ótima performance é caracterizada por um indice maior que $95 \%$ de rebolos sem cisalhamento de ambos os lados.

\subsection{Desempenho econômico da colhedora}

Através das informações obtidas nos estudos de campo $e$, os dados econômicos obtidos conforme metodologia citada em 3.2.9, foram criados 16 fluxos de caixa para as 4 velocidades ensaiadas e as 4 Eficiências de Campo adotadas. Obteve-se os 16 fluxos de caixa apresentado nos anexos, resultando no quadro 7 . 
Quadro 7. Custo de colheita para a colhedora, nas 16 Capacidades Operacionais adotadas, considerando 18.900 horas em 6 anos de vida útil.

\begin{tabular}{|c|c|c|c|c|}
\hline $\begin{array}{l}\text { Velocidade } \\
\left(\mathrm{km} \cdot \mathrm{h}^{-1}\right)\end{array}$ & $\begin{array}{c}\text { Eficiência } \\
\text { de Campo } \\
(\%)\end{array}$ & $\begin{array}{l}\text { Custo hora } \\
\text { US } \$ h^{-1}\end{array}$ & $\begin{array}{c}\text { Cap. Operacional } \\
t^{-h^{-1}} \\
\end{array}$ & $\begin{array}{c}\text { Custo tonelada } \\
\text { US } \$ \mathrm{t}^{-1} \\
\end{array}$ \\
\hline \multirow{4}{*}{ V1 } & 45 & 52,62 & 13,79 & 3,82 \\
\hline & 55 & 55,04 & 16,85 & 3,27 \\
\hline & 65 & 57,46 & 19,92 & 2,88 \\
\hline & 75 & 59,88 & 22,98 & 2,61 \\
\hline \multirow{4}{*}{ V2 } & 45 & 53,00 & 24,44 & 2,17 \\
\hline & 55 & 55,50 & 29,87 & 1,86 \\
\hline & 65 & 58,01 & 35,30 & 1,64 \\
\hline & 75 & 60,51 & 40,73 & 1,49 \\
\hline \multirow{4}{*}{ V3 } & 45 & 54,81 & 45,94 & 1,19 \\
\hline & 55 & 57,71 & 56,14 & 1,03 \\
\hline & 65 & 60,62 & 66,35 & 0,91 \\
\hline & 75 & 63,53 & 76,56 & 0,83 \\
\hline \multirow{4}{*}{ V4 } & 45 & 55,91 & 59,37 & 0,94 \\
\hline & 55 & 59,06 & 72,56 & 0,81 \\
\hline & 65 & 62,21 & 85,75 & 0,73 \\
\hline & 75 & 65,37 & 98,95 & 0,66 \\
\hline
\end{tabular}

Observando-se o custo por tonelada de cana, do quadro 7, para as diversas velocidades e Eficiências de Campo, elaborou-se os cenários mostrados na figura 42.

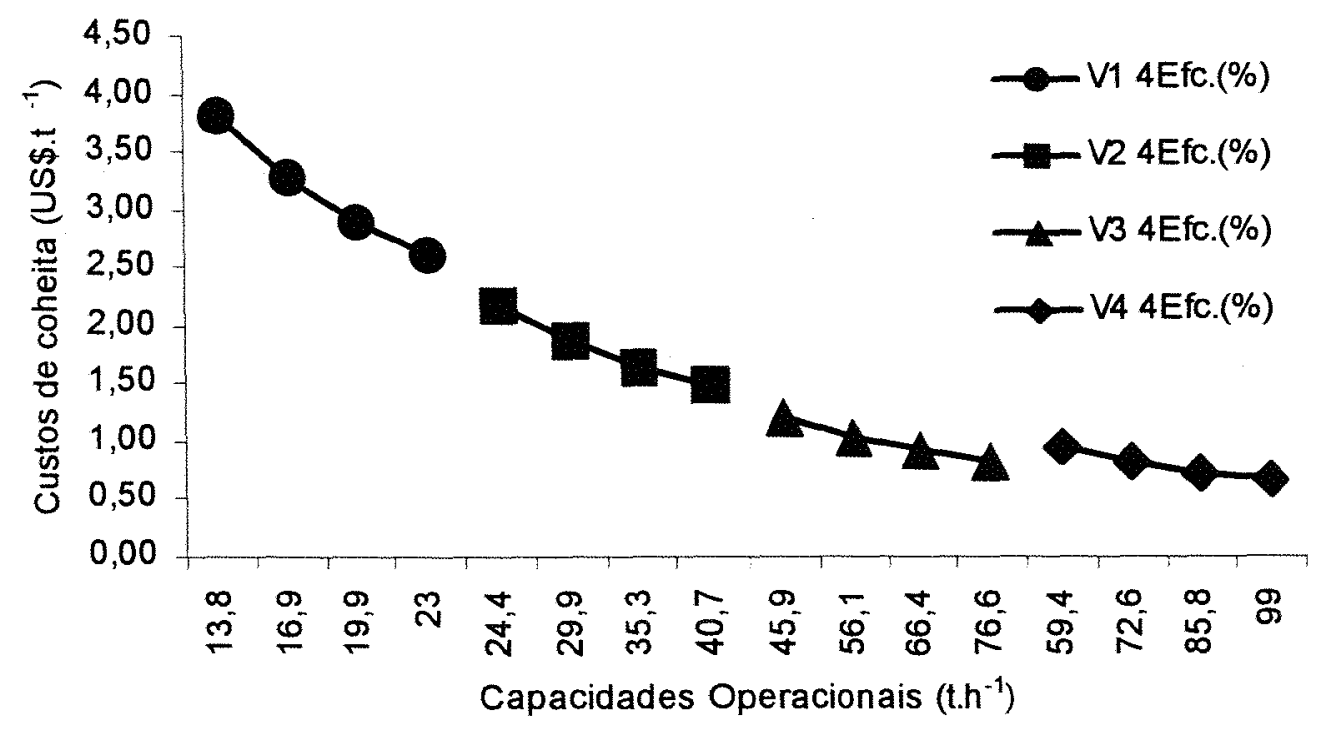

Figura 42. Representação dos Custos da colhedora, para as 16 Capacidades Operacionais. 
Os cenários apresentados mostram custos de colheita variando de 0,66 a 3,82 US $\$ \mathrm{t}^{-1}$ de cana colhida. Estes valores indicam que velocidades e Eficiências de Campo baixas podem tornar o custo alto da colheita, diminuindo a competitividade do produto final pela Usina.

Observa-se pelos resultados obtidos, que a Eficiencia de Campo de colheita da Usina, é fator preponderante para a diminuição do custo por tonelada de cana colhida, embora o aumento da velocidade de trabalho também seja fator importante (não se levando em consideração a qualidade do trabaho).

Através dos dados do quadro 7, elaborou-se uma Regressão, através da curva apresentada na figura 43 .

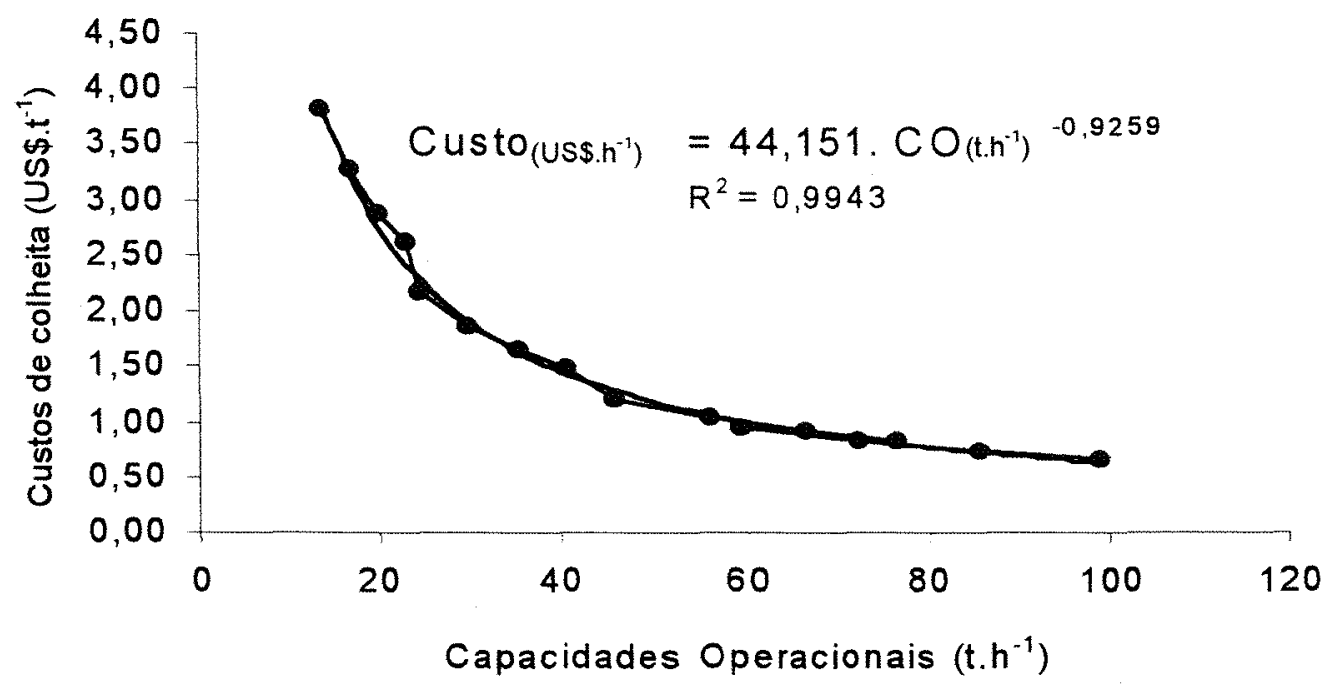

Figura 43. Regressão obtida para Custos da colhedora, nas 16 Capacidades Operacionais.

Através da Regressão apresentada na figura 43, pode-se inferir custos de colheita, através de Capacidades Operacionais em Eficiências de Campo na colheita mecanizada de cana-de-açúcar com eficiências variando de 45 a $75 \%$.

Lima (1988) apresentou Custos de colheita mecânica com 4 colhedoras, variando de 0,94 a 2,02 US\$. $\mathrm{t}^{-1}$. A Empresa Brastoft (1998) apresentou em Boletim técnico no Agrishow 98, custos de colheita mecânica de 1,11 e 1,21 US\$.t. Mialhe (1982) mostram, custos de colheita mecanizada de 1,88; 2,2 e 3,15 US $\$ . t^{-1}$ para 
uma colheita de $300.000,200.000$ e 100.000 t de cana colhida respectivamente, numa safra.

Kronka \& Monteiro (1999) apresentam um custo de colheita mecanizada de 2,09 US $\$ \mathrm{t}^{-1}$ para cana sem queima prévia.

Observa-se que os valores apresentados pelos vários autores, mostram custos resultantes próximos, das velocidades V 1 e V4 e, Eficiências de campo de $55 \%$ e $45 \%$ respectivamente, obtidos neste estudo. Pode-se inferir que, na prática, não se utilizam velocidades de colheita abaixo de V1 com Eficiências de Campo de $45 \%$ e, velocidades maiores que V4 com Eficiências de Campo de $55 \%$.

Os custos da colheita mecanizada, sofrem grandes influências de velocidades de deslocamento da colhedora e Eficiências de Campo, não permitindo assim a simples comparação de valores finais entre máquinas, Empresas e metodologias de levantamento de dados diferentes. Sendo necessário uma metodologia padronizada de ensaio.

Utilizando-se como um exercicio de observação, tomou-se dados de dispêndios em percentagem, na V2 com eficiência de $45 \%$, apresentados no Fluxo de caixa da tabela 63 dos anexos, onde se observa, pela figura 44 , os itens por grau de importância.

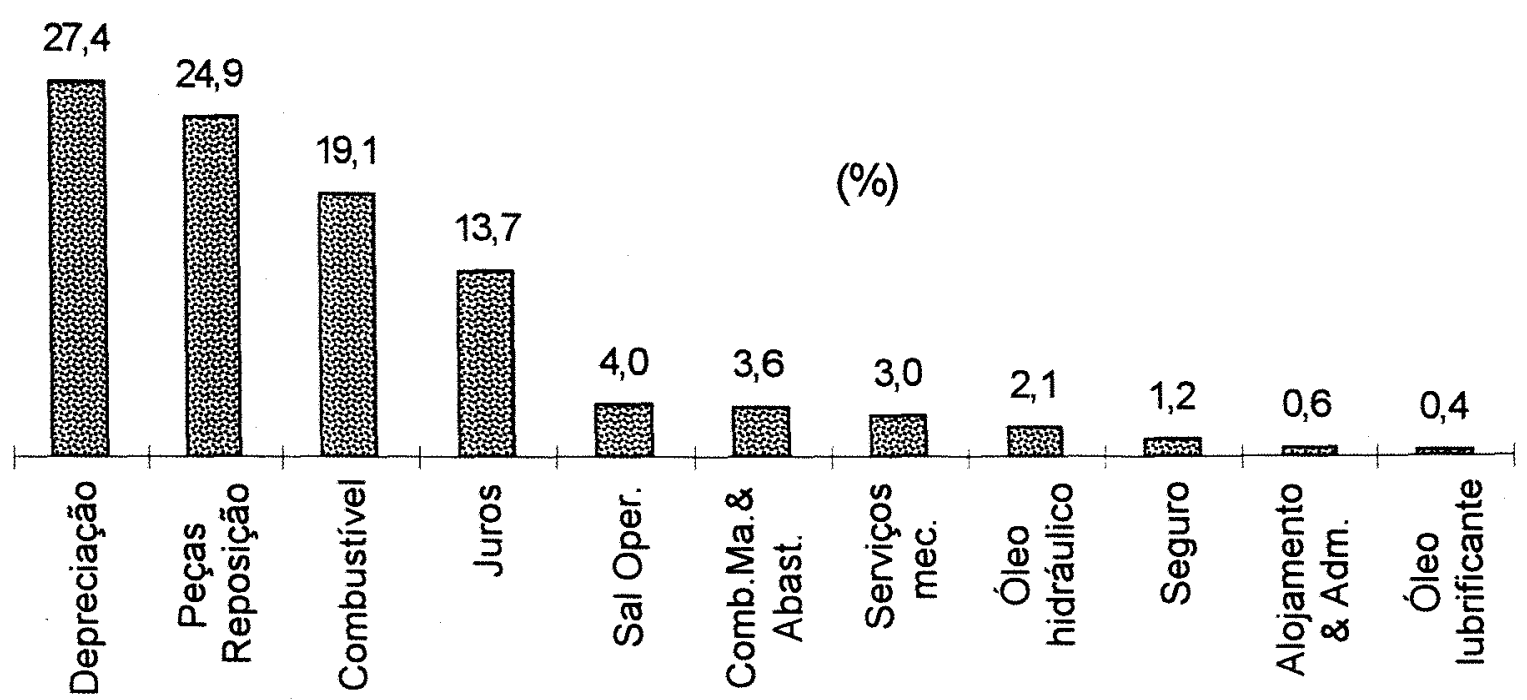

Figura 44. Itens de Dispêndios em \%, da colhedora na V2 e Eficiência de Campo de $45 \%$. 
Observa-se que o Valor Inicial da colhedora é de grande importância, pois o item Depreciação (função do valor de aquisição da máquina) é grande. Os outros itens Peças de Reposição, Combustivel e Juros, também têm valores elevados, devendo ser trabalhados gerencialmente, como por exemplo um treinamento elou salário melhor para o operador, podem gerar uma grande economia em Consumo de Combustível e durabilidade de Peças de Reposição.

Noronha et al. (1991) mostram, que o Custo com Consumo de Combustivel para tratores agricolas representam de 20 a $50 \%$ de seu Custo hora. Neste trabalho encontramos o Custo hora com Consumo de Combustivel da ordem de 19,1\%; portanto um pouco abaixo do limite inferior para o serviço de grande esforço variável de um trator agricola.

A Empresa Brastoft (1998) apresentou, em Boletim técnico no Agrishow 98, percentuais de dispêndio de Custo hora de colheita mecânica, como segue: $39,3 \%$ em Depreciação da máquina; 27,2 \% em Peças e Serviços de Manutenção, 23,6 \% em Combustivel; $8,1 \%$ em Mão de Obra do Operador e, 1,8 \% em Lubrificantes. Comparando com este estudo, observamos que o custo com o item Depreciação da colhedora Brastoft, esta bem acima da máquina deste estudo; o item Peças e Serviços de Manutenção têm custos muito próximos; o item Combustível está com custo $4 \%$ acima; o custo com o item Lubrificante está muito próximo, admitindo que o valor apresentado pela Brastoft considera a soma do custo de óleos lubrificante e hidráulico. A maior diferença entre a comparação de custos está no item, Custo da Mão de Obra do Operador da colhedora, de praticamente o dobro do custo apresentado no boletim Brastoft.

O item, custos de Peças de Reposição e Serviços Mecânicos (peças e mão de obra), fornecidos pela Usina em estudo, mostra através da figura 45 , a estimativa destes custos ao longo de 7 anos. 


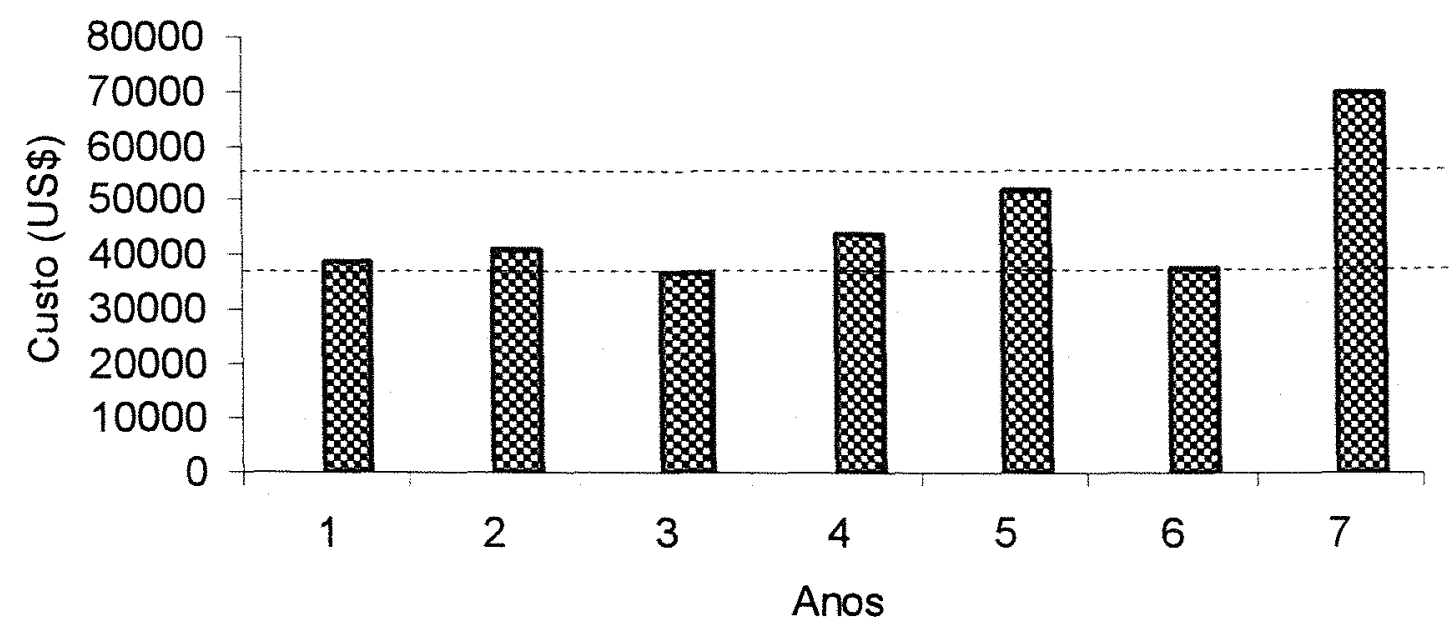

Figura 45. Estimativa de custos de Peças de Reposição \& Serviços Mecânicos da colhedora, em 7 anos.

Nota-se que o custo com Manutenção, permanece dentro de uma "normalidade" até os seis anos de vida, e no $7^{\circ}$ ano este custo aumenta em aproximadamente $82 \%$, praticamente dobra, indicando provável prejuizo na utilização da colhedora. 


\section{CONCLUSÕES}

\subsection{Condições do canavial}

O canavial estava adequado para colheita mecanizada em cana crua.

\subsection{Desempenho operacional da colhedora}

Os resultados obtidos confirmam a hipótese de que a variável velocidade de deslocamento, reflete nos desempenhos operacionais de colhedoras, sob mesmas condições de campo.

A Capacidade Efetiva Bruta $\left(C_{b}\right)$, apresentou diferenças significativas entre as duas velocidades mais baixas e as mais altas.

$A$ velocidade $V 1$, apresentou menor Eficácia de Manipulação $\left(E M_{t}\right)$, em relação às demais velocidades.

A Capacidade Efetiva Liquida ( $\left.C E_{1}\right)$ apresentou o melhor resultado na velocidade V4, eo pior na velocidade $\mathrm{V} 1$.

As Capacidades Operacionais (CO), obtidas através de 4 eficiências adotadas aumentaram, conforme o aumento da velocidade de deslocamento e da eficiência de campo. $A$ maior Capacidade Operacional ocorreu na velocidade V4 com uma Eficiência de Campo de $75 \%$.

O menor Consumo de Combustivel (CC) em I. $\mathrm{h}^{-1}$, ocorreu na velocidade V1 e o maior ocorreu na velocidade $\mathrm{V} 4$.

O menor Consumo de Combustivel (CC) em $1 . \mathrm{t}^{-1}$, ocorreu na velocidade $\mathrm{V} 4 \mathrm{e}$ o maior ocorreu na velocidade $\mathrm{V} 1$.

\subsubsection{Perdas de matéria-prima no campo}

Colmos e suas Frações (CF), Rebolos Inteiros (RI), Frações de Rebolos (FR), Rebolos na Soqueira (RS) e Raizes (RT), não sofreram influências das velocidades de deslocamento da colhedora, muito embora tratando os valores de perdas totais deixadas no campo (PTc), tivesse 
havido diferenças com melhor resultado na velocidade $\mathrm{V} 3$ e pior resultado na velocidade $\mathrm{V} 1$.

As Menores Perdas Totais deixadas no campo ocorreram, portanto, na velocidade V3, tornando a colheita nesta velocidade a mais econômica com menos Perdas.

\subsubsection{Qualidade de matéria prima colhida}

Os Índices de Ponteiros (IP), Índice de Folhas Verdes (IFv), Índice de Raizes (IR), Índice de Matéria Estranha Vegetal (IV), Índice de Matéria Estranha Mineral (IM), bem como o índice de Matéria Estranha Total, não apresentaram diferenças significativas das velocidades de deslocamento da colhedora. Somente o índice de palhas $\left(\mathrm{IP}_{\mathrm{a}}\right)$, apresentou diferença significativa entre a velocidade mais baixa $\mathrm{V} 1$ e a mais alta $\mathrm{V} 4$, demonstrando que o mecanismo de processamento e limpeza da matéria prima perdeu a estabilidade, com a mudança destas velocidades.

O menor Índice de Matéria Estranha Total ocorreu na velocidade V3, e o maior na velocidade $\mathrm{V} 1$.

\subsubsection{Comprimento e Cisalhamento dos rebolos}

A menor variação para o Comprimento dos Rebolos ocorreu na velocidade mais baixa $\mathrm{V} 1$, e a maior variação ocorreu na velocidade V3.

O menor Índice de Cisalhamento dos Rebolos ocorreu na velocidade V1.

\subsection{Desempenho econômico da colhedora}

Os Custos de colheita mecanizada sofreram influência das diferentes velocidades de deslocamento e das Eficiências de Campo estimadas. Velocidades e eficiências de campo baixas, aumentam os custos por tonelada colhida.

Os itens de dispêndios do custo de colheita mais significativos foram: a depreciação da colhedora e portanto seu valor de compra; peças de reposição; combustivel e juros. Estes itens devem ter um tratamento gerencial melhor.

O custo de manutenção da colhedora aumenta muito a partir do $7^{\circ}$ ano, indicando que a vida economicamente ideal, para a colhedora, é de 6 anos. 


\section{REFERÊNCIAS BIBLIOGRÁFICAS}

ANDRIETA, M.G.S. Novas alternativas para subprodutos da cana-de-açúcar. In: $3^{\text {a }}$ SEMANA DA CANA-DE-AÇÚCAR DE PIRACICABA - SECAPI' 98, 3., Piracicaba, 1998. Anais. Piracicaba, STAB. Açúcar, Álcool e Subprodutos, 1998. p.10-12.

ANON, A. Colheita da cana no Havai. Brasil Açucareiro, Rio de Janeiro, Abr. 1953. p.74-77.

AUDSLEY, E., WHEELER J. The annual cost of machinery calculayed using actual cash flows. Journal of Agricultural Engineering Research, Washington, v.23, 1978, p.189-201.

BALBO, L. Análise de viabilidade técnico econômica do sistema de colheita mecanizada de cana. In: ENCONTRO TÉCNICO, 8., Ribeirão Preto, 1992. Apostila. Ribeirão preto, grupo de trabalho de manutenção e Mecanização no setor sucroalcooleiro, 1992. p.185-204.

BALASTREIRE, L.A. Determinação do ponto de renovação de frotas mecanizadas. STAB. Açúcar, Álcool e Subprodutos, Piracicaba, v.13, n.3, jan./fev. 1995. p.3134.

BARBIERI, J.L. Compactação dos solos: diagnóstico e correção. In: SEMINÁRIO SOBRE TECNOLOGIAS DE MANEJO DE SOLO E ADUBAÇÃO DA CANA-DEAÇÚCAR, 1., Ribeirão Preto, 1995. Anais. Ribeirão Preto, IDEA, 1995. p.14-27.

BASSINELO, A.I.; FURLANI NETO, V.L.; MACEDO, N.; PARAZZI, C.; CASAGRANDE. J.C. Implicações agrícolas e industriais da colheita de cana crua. Araras: IAA/PLANALSUCAR, s.d. 55p. 
BELLINASO, I.F. Relatório técnico de compactação do solo - Safra 93/94. Piracicaba: Centro de Tecnologia copersucar, 1993.

BELODI, C.O. Processamento de cana sem desponte; experiência da açucareira Quatá. STAB. Açúcar, Álcool e Subprodutos, Piracicaba, v.6, n.3, abr./maio, 1988. p.41-48.

BELODI, C.O. Novos patamares de custos e desafios para o setor sucroalcooleiro. In: SEMINÁRIO SOBRE REDUÇÃO DE CUSTOS NA LAVOURA CANAVIEIRA, 2., Ribeirão preto, 1998. Anais. Ribeirão Preto, IDEA, 1998. p.1-18.

BETANCOURT, A.F. Matérias estrañas en la cosecha de la caña de azúcar: estudio general. Boletin Oficial de la Associaçón de Técnicos Azucareros de Cuba, Havana, v.2, n.3, 1967. p. 22-29.

BOFILL, A.; DÍAZ, J.A.; GUYÓN, L.; MARTINEZ, R. Appication of mathematical methods to the management of sugar cane enterprises. Computer Applications in Food Production and agricultural Engineering. IFP, 1982. p.175-190.

BOHM, G.M. Queima de cana-de-açúcar e saúde humana. In: 3 SEMANA DA CANADE-AÇÚCAR DE PIRACICABA - SECAPI' 98, 19., Piracicaba, 1998. Anais. Piracicaba, STAB. Açúcar, Álcool e Subprodutos, 1998. p.40-41.

BONINE JUNIOR, P.A. Colheita mecanizada em cana de açúcar: viabilidade operacional e econômica. In: CONGRESSO NACIONAL DA SOCIEDADE DOS TÉCNICOS AÇUCAREIROS E ALCOOLEIROS DO BRASIL, 5., Águas de São Pedro, 1993. Anais. Águas de São Pedro, STAB, 1993. p.186-191.

BRASIL. Leis, Decretos, etc. Decreto no 42.056 de 06 de agosto de 1997. Diário Oficial do Estado de São Paulo, 06 de agosto de 1997. Seção 1,p.3-4. Dispõe sobre o uso, conservação e preservação do solo agricola para o Estado de São Paulo.

BRASTOFT. Boletim técnico de dados de colhedoras de cana. Ribeirão Preto, 1998. 28p. (apresentado no Agrishow). 
CÂMARA, G.M.S. \& OLIVEIRA, E.A.M. Produção de Cana-de-açúcar. 1. Ed. Piracicaba, ESALQ/FEALQ, 1993. 242p.

CERQUEIRA LUZ, P.H.; ALOISI, R.R. Influência das colheitas manual e mecânica sobre o rendimento industrial da cana-de-açúcar. Álcool \& Açúcar, v.11, n. 58, mai./jun., 1991. p.24-27.

COSTA FILHO, R.M. Queima da cana-de-açúcar. Piracicaba: Boletim Técnico Copersucar, n. 10, 1979. p.8-2.

CHURCHWARD, E.H. \& POULSEN, N.J. Review of harvestin developments. Austrália: Proceedings of Australian Socierty of Sugar Cane Technologists, 1988. p.1-6.

DELGADO, A.A. Os efeitos da queima dos canaviais. STAB. Açúcar, Álcool e Subprodutos, Piracicaba, v.3, n.6, jul./ago. 1985. p.42-45.

DELGADO, A.A \& MAFRA, R.L. Cana com desponte: uma vantagem ou uma necessidade industrial? Revista Usineiro, São Paulo, v.4, n.19, nov./dez. 1989. p.58-65.

FERNANDES, A.C. \& OLIVEIRA, E.R. Impurezas em carregamento de cana-deaçúcar. Piracicaba: Boletim Técnico Copersucar, n.5, set. 1977. p.5-8.

FERNANDES, A.C. \& IRVINE, J.E. Comparação da produtividade da cana-de-açúcar por colheita mecanizada e por corte manual. STAB. Açúcar, Álcool e Subprodutos, Piracicaba, v.4, n.6, jul.lago. 1986. p.112-6.

FURLANI NETO, V.L. , FERNANDES, J., MIALHE, L.G. Avaliações nas cargas de cana-de-açúcar colhidas mecanicamente. In: VIII Congresso Brasileiro de Engenharia Agrícola. Botucatu, 1978. Anais Botucatu, CONBEA. 1978. 19p.

FURLANI NETO, V.L.; FERNANDES, J.E.; STOLF, R. Avaliação de impurezas nas cargas e perdas no campo pela colhedora mecanizada de cana inteira. Araras: IAA-PLANALSUCAR, 1981. 14p. 
FURLANI NETO, V.L. Incidência da matéria estranha e perdas no campo nos processos de corte manual e com colhedoras amontoadoras em cana-de-açúcar (Saccharum Spp). Piracicaba, 1984. 120p. Dissertação (M.S.) - Escola Superior de Agricultura "Luiz de Queiroz", Universidade de são Paulo.

FURLANI NETO, V.L.; FERNANDES, J.; STOLF, R.; COLETTI, J.T. Perdas no campo pelo sistema de corte mecanizado com canas inteiras amontoadas. Saccharum, São Paulo, v.33, n.7, jul./ago. 1984. p.30-3.

FURLANI NETO, V.L.; MONTEIRO, H.; RIPOLI, T.C.C.; NOGUEIRA, R.R. Comparative analysis between green cane and burned cane: raw matter quality, cane losses, crop residue and chopper harvest performance. In: CONGRESS OF INTERNATIONAL SOCIETY OF SUGAR CANE TECHNOLOGISTS, 20., São Paulo, 1989. Proceedings. São Paulo, ISSCT, 1989. v.2, p.1043-50.

FURLANI NETO, V.L. A colheita da cana crua (sem queima) no Brasil. Piracicaba: ESALQ/USP, 1991. 31p.

FURLANI NETO, V.L. Colheita mecanizada de cana-de-açúcar. STAB. Açúcar, Álcool e Subprodutos, Piracicaba, v.3, n.12, 1994. p.8-9.

FURLANI NETO, V.L. Sulcos alternados duplos (SAD) e simples - controle de tráfego na colheita de cana picada. STAB. Açúcar, Álcool e subprodutos, Piracicaba, v.13, n.4, mar./abr. 1995. p.14-18.

FURLANI NETO, V.L.; RIPOLI, T.C.C.; VILLA NOVA, N.A.; APPROBATO FILHO, A. Colheita mecanizada de cana crua e queimada: desempenhos e qualidade da matéria prima. In: CONGRESSO NACIONAL DA SOCIEDADE DOS TÉCNICOS AÇUCAREIROS E ALCOOLEIROS DO BRASIL, 6., Maceió, 1996. Anais. Maceió, STAB, 1996. p.533-41.

FURLANI NETO, V.L; RIPOLI, T.C.C.; VILLA NOVA, N.A. Colheita mecânica: perda de matéria prima em canaviais com e sem queima prévia. STAB. Açúcar, Álcool e subprodutos, Piracicaba, v.14, n.6, jul./ago. 1996. p.14-18. 
FURLANI NETO, V.L; RIPOLI, T.C.C.; VILLA NOVA, N.A. Avaliação de desempenho operacional de colhedora em canaviais com e sem queima prévia. STAB. Açúcar, Álcool e subprodutos, Piracicaba, v.15, n.2, nov./dez. 1996. p.18-23.

FURLANI NETO, V.L. Quebra de paradigmas na cultura canavieira, sistematização, amostragens, preparo e plantio. STAB. Açúcar, Álcool e subprodutos, Piracicaba, v.16, n.5, mai./jun. 1998. p.13.

FREITAS, P.G.R. Experiências e resultados do uso de cortadoras mecânicas. Álcool \& Açúcar, v.1, n.1, 1981. p.62-63.

GANDINI, M.O.; GAZON, A.L.; CONDE, A.J.; DONZELLI, J.L. Conservação de solos e planejamento de sulcação em áreas de colheita mecânica de cana crua. In: CONGRESSO NACIONAL DA SOCIEDADE DOS TÉCNICOS AÇUCAREIROS E ALCOOLEIROS DO BRASIL, 6., Maceió, 1996. Anais. Maceió, STAB, 1996. p.521-31.

GENTIL, L.B.V. Cana-de-açúcar: colheita mecânica como um todo. Brasil Açucareiro, Rio de Janeiro, v.4, 1977. p.42-54.

HERRERA, M. de A.; LINARES, S.O. La incidencia del rendimiento agrícola em la eficiencia de limpeza y las perdidas de la KTP-1 cosechando em verde, Cuba Azúcar, v.8, n.2, jan./mar. 1986. p.13-16.

HOFFMANN, R. Custos da produção. In: Administração da empresa agricola. São Paulo, SP. Ed. Pioneira, 1987. 5. Ed., p.07-55.

HUBERT, R.P. Improving burns with desiccants as an aid to mechanical harvesting proceedings. CONGRESS OF INTERNATIONAL SOCIETY OF SUGAR CANE TECHNOLOGISTS. n.2, 1974. p.1065-73.

INSTITUTO DE DESENVOLVIMENTO AGROINDUSTRIAL. Indicadores de desempenho da agroindústria canavieira - safra 97/98. Ribeirão Preto, IDEA, 1998. $116 p$ 
KIEHL, E. J. Manual de edafologia: Relação solo-água-planta. São Paulo. Ceres. 1979. 264p.

KIRCHHOFF, V.W.J.H. Queimadas na Amazônia e efeito estufa. São José dos Campos, Ed. Contexto, 1992. 118p.

KRONKA, P.F.B.; MONTEIRO, J.H. Desempenho operacional de colhedoras na Usina Iturama. In: SEMANA DE CANA DE PIRACICABA- 4" SECAPI, Piracicaba, 1999. Anais. Piracicaba, 1999. p.46-48.

LIMA, L.O.T. Fatores que influenciam na colheita mecânica. In: SEMINÁRIO DE COLHEITA MECÂNICA 1, Ribeirão Preto, 1994.

LIMA, L.O.T. Custo de colheita mecanizada. STAB. Açúcar, Álcool e Subprodutos, Piracicaba, v.16, n.4, mar./abril, 1998. p.29-30.

LINS, G.E. Análise econômica de investimentos. Rio de Janeiro, APEC Editora S.A., 1975. 264p.

LOPES, M.B. Simulação de um sistema de carregamento e transporte de cana-deaçúcar. Piracicaba, 1995. 143p. Dissertação (M.S.) - Escola Superior de Agricultura "Luiz de Queiroz", Universidade de são Paulo.

LUCCHESI, A.A. Processos fisiológicos da cultura da cana-de-açúcar (Saccharum spp). 1. Ed. Piracicaba, ESALQ/FEALQ, 1995. 50p.

LUZ, P.H.C. Efeitos de sistemas de colheita e formas de cultivo de soqueira sobre a produção e qualidade tecnológica da cana-de-açúcar (Saccharum spp). Piracicaba, 1989. 135p. Dissertação (M.S.) - Escola Superior de Agricultura "Luiz de Queiroz", Universidade de são Paulo.

MACEDO, I.C. Greenhouse gases and bio-ethanol in Brazil. INTERNATIONAL SUGAR JOURNAL, v.c., n.11, 1989, p.2-5. 
MAGRO, J.A. Colheita de cana crua na Austrália. JORNALCANA, Ribeirão Preto, Série II, Ano VI, n.64, abril. 1999. p. 32-33.

MELO, F.A.D.; BORBA, J.M.M.; PATERSON, M. Cana-de-açúcar integral e queimada sem desponte; resultados preliminares obtidos. Brasil Açucareiro, Rio de Janeiro, v.106, n.5/6, 1988. p.33-37.

MIALHE, L.G.; RIPOLI, T.C.C.; MILAN, M. Algumas considerações sobre o formato de talhões e espaçamento de plantio. Álcool \& Açúcar, São Paulo, v.4, 1994. p.2933.

MIALHE, L.G. \& RIPOLI. T.C.C. Evaluación de cosechadoras automotrices de caña de azúcar. Caracas: Distribuidora Venezolana de Azúcares. $\quad$ 1976. p.189284.

MIALHE, L.G.; CARRARO NETO, H.C. Avaliação e análise do desempenho da colhedora de cana-de-açúcar. Olímpia: Usina Cruz alta de Olímpia S.A., Olímpia, SP. 1993. 169p. (Relatório técnico de ensaio de máquina)

MORAES, E.E. Avaliação das perdas invisiveis de cana-de-açúcar (Saccharum spp) e impurezas vegetais na colheita mecânica. Campinas, 1992. 92p. Dissertação (M.S.) - Faculdade de Engenharia Agrícola, Universidade estadual de campinas.

MORAES, E.E. \& NEVES, J.L.M. Colheita de cana crua: perdas no campo e impurezas na carga. In: SEMINÁRIO DE TECNOLOGIA AGRONÔMICA, 7., Piracicaba, 1997. Anais. Piracicaba, copersucar. 1997. p.298-300.

MORAES, E.E. \& NEVES, J.L.M. Colheita de cana crua: avaliação de perdas invisiveis nos sistemas com colhedora de cana picada. In: SEMINÁRIO DE TECNOLOGIA AGRONÔMICA, 7., Piracicaba, 1997. Anais. Piracicaba, copersucar. 1997. p.288297.

MOREIRA, C.A. \& MENEZES, JF. O custo operacional da maquinaria agricola. Atual agronômica, São Paulo, v.1, n.1, fev./mar. 1973. p.38-48. 
MUTTON, M.J.R.; STUPIELLO, J.P.; MUTTON, M.A.; BARBOSA, J.C. Conseqüências das impurezas minerais na avaliação da qualidade da cana. STAB. Açúcar, Álcool e Subprodutos, Piracicaba, v.10, n.4, mar./abr. 1992. p.17-22.

NOA H. La caña de azúcar como base de un desarollo agro-industrial postenible. In: CONFERENCIA MUNDIAL SOBRE O DESENVOLVIMENTO E O MEIO AMBIENTE. Rio de Janeiro. 1992. Trabalhos apresentados. Rio de Janeiro, 1992. p 12-15.

NORONHA, J.F.; MIALHE, L.G.; DUARTE, L.P. Custos dos sistemas tratorizados na agricultura Brasileira. In: CONGRESSO BRASILEIRO DE ECONOMIA E SOCIOLOGIA RURAL, 29., Campinas, 1991. Anais. Campinas, Saber, BrasiliaDF, 1991. p.13-33.

NUNES JUNIOR, D. A vitória da cana crua. STAB. Açúcar, Álcool e subprodutos, Piracicaba, v.16, n.6, jul./ago. 1998. p.8.

NUNES JUNIOR, D. \& PINTO, R.S.A. As perspectivas para o centro-sul nas safras 99/00 e 00/01: oportunidades estratégicas. In: SEMINÁRIO SOLUÇÕES E NOVIDADES NA MECANIZAÇÃO DA CANA-DE-AÇÚCAR - 23 E 24/03/99, Ribeirão Preto, 1999. Anais. Ribeirão Preto, IDEA. 1999. p.63-80.

PAIXÃO, M. No coração do canavial: estudo crítico do complexo agro-industrial sucroalcooleiro e das relações de trabalho na lavoura canavieira (estudo comparativo em doze Estados do Brasil). Rio de Janeiro, 1994. 176p. Dissertação (M.S.) - COPPE, Universidade Federal do Rio de Janeiro.

PAYNE, J.H. Sugar and energy losses in burned cane. International Sugar Journal, London, v.88, n.1054, oct. 1986. p.191-2.

PETERSON, C.L., MILLIGAN J.H. Economic life analysis for machinery replacement decisions. Transactions of the ASAE. St. Joseph, v.19, n.5, 1976, p. 819-822. 
PEIXOTO, A.A. \& DELGADO, F.R.M.C.R. Manejo da colheita: I. Rendimentos de corte e embarque, com eitos de 5 e 7 linhas. Brasil Açucareiro, Rio de Janeiro, v.106, n.2, 1988. p.33-37.

PEIXOTO, A.A. \& DELGADO, F.R.M.C.R. Manejo da colheita: II. Índices de impurezas na matéria-prima, com o corte em eitos de 5 e 7 linhas. Brasil Açucareiro, Rio de Janeiro, v.106, n.3, 1988. p.13-7.

PEIXOTO, A.A. \& DELGADO, F.R.M.C.R. Manejo da colheita: III. Perdas de cana no campo, com o corte em eitos de 5 e 7 Linhas. Brasil Açucareiro, Rio de Janeiro. V.106, n.3, 1988. p. $18-21$.

PEREIRA, V. Avaliação da nova sistemática de corte de cana implantada na região de Ribeirão Preto na safra 83/84. STAB. Açúcar, Álcool e Subprodutos. Piracicaba, v.2, n.2, nov./dez. 1983. p.16-21.

RIPOLI, M.L.C. \& RIPOLI, T.C.C. Variação de temperatura de queima de canavial. In: SIMPÓSIO DE INICIAÇÃO CIENTÍFICA DA USP, 3, Piracicaba, 1995. Resumos. Piracicaba: ESALQ, 1995. p. 406.

RIPOLI, M.L.C. \& RIPOLI, T.C.C. Caracterização dos principais constituintes da biomassa de variedades de cana-de-açúcar. In: SIMPÓSIO DE INICIAÇÃO CIENTÍFICA DA USP, 4, Piracicaba, 1996. Resumos. Piracicaba: ESALQ, 1996. p. 463.

RIPOLI, T.C.C. Corte, Carregamento, Transporte e recepção de cana-de-açúcar. Piracicaba, DER-ESALQ-USP, 1974. 52P.

RIPOLI, T.C.C.; RIGHI. J.C.; PEXE, C.A. Estudo comparativo entre três métodos de corte de cana-de-açúcar. In: SEMINÁRIO COPERSUCAR DA AGROINDÚSTRIA AÇUCAREIRA, 3., Águas de Lindóia, 1975. Anais. Águas de Lindóia, Copersucar, 1975 p. $335-44$. 
RIPOLI; T.C.C., MIALHE, L.G., NOVAES, H.P. Um critério para avaliação do estado de canavial visando a colheita. In: Separata de Anais do congresso brasileiro de engenharia agrícola 9, v.4., Pelotas: SBEA, 1977. 10p.

RIPOLI, T.C.C. \& ALVES BERTO P.N. Avaliação de desempenho de colhedoras de cana-de-açúcar na região de Campos, RJ. Brasil Açucareiro, Rio de Janeiro. V.49, n.2, fev., 1981. p.30-31.

RIPOLI, T.C.C. \& MIALHE, L.G. Custos de colheita da cana-de-açúcar no estado de São Paulo, 1981/82. Álcool \& Açúcar, São Paulo, v.2, n.2, 1982. p.18-26.

RIPOLI, T.C.C.; MILAN, M.; MIALHE, L.G.; FAGANELLO, B.F.: MONTEIRO, H.; FURLANI NETO, V.L. Carregamento mecânico: Ensaios com tipos de eitos e recolhedor de cana. In: CONGRESSO NACIONAL DA STAB. 3., São Paulo, 1984. Anais. São Paulo, 1984. p.135-39.

RIPOLI, T.C.C. Modelagem de desempenho operacional de carregadora auto propelida para cana-de-açúcar (Saccharum spp). Piracicaba. 1986. 102p. Dissertação (M.S.) - Escola Superior de Agricultura "Luiz de Queiroz", Universidade de São Paulo.

RIPOLI, T.C.C. \& MIALHE, L.G. Colheita manual vs. Colheita mecanizada da cana-deaçúcar. STAB. Açúcar, Álcool e Subprodutos, Piracicaba, v.5, n.3, jan.ffev. 1987. P.27-37.

RIPOLI, T.C.C. \& PARANHOS, S.B. Cana-de-açúcar; colheita. In: PARANHOS, S. B., Coord. Cana-De-Açúcar: Cultivo E Utilização. Campinas, Fund. Cargill, 1987. p.517-97.

RIPOLI, T.C.C. \& VILLANOVA, N.A. A colheita mecanizada da cana-de-açúcar: novos desafios. STAB. Açúcar, Álcool e Subprodutos, Piracicaba, v.11, n.1, set./out. 1992. p.28-31.

RIPOLI, T.C.C.; TILLMANN, C.A.C.; MILAN, M. O corte manual na cana verde. Álcool \& Açúcar, São Paulo, v.15, n.77, dez.jjan. 1995, p.28-30. 
RIPOLI, T.C.C. Ensaio \& Certificação de máquinas para colheita de cana-deaçúcar. In: MIALHE, L.G. Máquinas Agrícolas: Ensaios e Certificação. Piracicaba, SP. Fundação de estudos agrários Luiz de Queiroz, 1996. cap. 13, p.635-671.

RIPOLI, T.C.C. E a energia de biomassa? JORNALCANA, Série II, Ano VI, n.64, abril. 1999. p. 37-38.

ROMERO, E.; ZAMORA, F.P.; OLEA, I.; SCANDALIARIS, J.; MARTÍN, L. Evaluación de nuevas cosechadoras integrales. Avance Agroindustrial, v.13, n.52, Mar, 1993. p.24-28.

ROSA, R.F.; MORAES, A.R.; GLÓRIA, N.A. Perdas na colheita manual da cana-deaçúcar com carregamento mecânico. STAB. Açúcar, Álcool e Subprodutos, v.11,n.3, jan./fev. 1993. p.25-28.

RUIZ, A.G. \& OROSCO, J.G. Sistema Cubano de cosecha en caña verde. In: SEMANA DE ATUALIZAÇÃO EM CANA-DE-AÇUCAR - TECNOCANA, Apostila. Araras, 1992. 17p.

RUIZ, A.G. \& OROSCO, J.G. Sistema cubano de colheita mecanizada de cana crua . JORNALCANA, Série II, Ano VI, n.64, abril. 1999. p. 34-36.

SHAW, G.R. \& BROTHERTON, G.A. Green cane harvesting. Australia: Proceedings of Australian Society of Sugar Cane Technologists. 1992. p.1-7.

SOARES, G.C.; BALBO, L.; PINTO, A.R. Colheita mecânica de cana picada. STAB. Açúcar, Álcool e subprodutos, Piracicaba, v.12, n.3, jan./fev. 1994. p.18-20.

SPAROVEK, G. Informações geográficas para a identificação de áreas com potencialidade para colheita de cana crua. In: SEMANA DE CANA- DE-AÇÚCAR DE PIRACICABA, 2., Piracicaba, 1997. Anais. Piracicaba, Comissão Organizadora, 1997. p.58-60.

STEEL, J. G., BRADFIELD, R. The significance of size distribution in the clay fraction. In: AMERICAN SOIL SURVEY ASS. Report Bulletin. 1934. p.88-93. 
STUPIELLO, J.P. Alguns aspectos da qualidade da matéria-prima. STAB. Açúcar, Álcool e Subprodutos, Piracicaba, v.7, n.3/5, jun./jul. 1989. p.52-4,

USINA GUARANI. Relatório gerencial (interno) de mecanização da colheita de cana. 1997. 36p.

URQUIAGA, S., RESENDE, A.S., ALVES, B.J.R., OLIVEIRA, O.C., BODDEY, R.M. Queima de cana. Revista Agrobiologia - EMBRAPA. Ribeirão Preto, n. 5, p. 2, Abr. 1997.

VEIGA FILHO, A.A.; SANTOS, Z.A.P.S.; VEIGA, J.E.R.; OTANI, M.N.; YOSHII, R.J. Estimativa de desemprego na colheita de cana decorrente de mecanização. STAB. Açúcar, Álcool e Subprodutos, Piracicaba, v.13, n.4, mar./abr. 1992. p.17-22.

ZAMPERLINI, G.C.M.; SILVA, M.R.S.; VILEGAS, W. Identification of polycyclic aromatic hydrocarbons in sugar cane soot by gas chromatography-mass spectrometry. Chromatographia, v.46, nov./dez., 1997. p.655-663.

ZARPELON, F.; STUPIELLO, J.P.; BACCARIM, L.M.; SILVA JÚNIOR, J.F.; PASQUOT, L.C.; BEZERRA, L.A. Controle químico da fabricação do açúcar. Copersucar 1978. $127 \mathrm{p}$. 
ANEXOS

Tabelas \& Quadros 
Tabela 1. Porte do canavial, em \%, de 12 repetições.

\begin{tabular}{lcc}
\hline Posição dos colmos & Porte $(\%)$ & C.V. $(\%)$ \\
\hline Ereto & $83,9(8,4)$ & 10,0 \\
Acamado & $11,6(9,9)$ & 85,3 \\
Deitado & $4,4(2,1)$ & 120,1 \\
\hline \#
\end{tabular}

\# Os valores entre parênteses, mostram o intervalo de confiança com $95 \%$ de probabilidade.

Tabela 2. Produtividade média, no canavial, de colmos, ponteiros, folhas verdes e palhas em t/ha, de 12 repetições, antes da passagem da colhedora.

Constituintes Produtividade $\left({\left.\mathrm{t} . h \mathrm{a}^{-1}\right)}^{-1}\right.$ Desvio padrão

\begin{tabular}{lcc}
\hline Colmos & $145,39( \pm 21,64)$ & 38,85 \\
Ponteiros & $6,56( \pm 1,31)$ & 2,32 \\
Folhas verdes & $14,08( \pm 2,05)$ & 3,63 \\
Palhas & $10,23( \pm 1,41)$ & 2,49 \\
Total & 176,26 & -- \\
\hline
\end{tabular}

\# Os valores entre parênteses, mostram o intervalo de confiança com $95 \%$ de probabilidade.

Tabela 3. Comprimento médio dos colmos,em $\mathrm{cm}$, de 12 repetições.

\begin{tabular}{lccc}
\hline Constituintes & Comprimento $(\mathrm{m})$ & Desvio padrão & C.V. \\
\hline Colmos & $3,29( \pm 0,07)^{\#}$ & 0,40 & 12,26 \\
\hline
\end{tabular}

\# Os valores entre parênteses, mostram o intervalo de confiança com $95 \%$ de probabilidade.

Tabela 4. Parâmetros de qualidade para determinação do grau e maturação da cultura.

\begin{tabular}{ll}
\hline Parâmetros & Valor \\
\hline Brix caldo (\%) & 18,0 \\
Pol caldo (\%) & 15,2 \\
Fibra cana (\%) & 15,1 \\
\hline
\end{tabular}

Tabela 5. Resumo da análise de variância para a variável, densidade média de colmos recolhidos pela colhedora, em tha ${ }^{-1}$.

\begin{tabular}{lcc}
\hline Causas da Variação & G.L. & Q.M. \\
\hline Velocidade & 3 & $409,10(0,24893)$ \\
Resíduo & 12 & 261,66 \\
\hline
\end{tabular}


Tabela 6. Produtividades médias de colmos recolhidos pela colhedora, em tha-1.

\begin{tabular}{lcc} 
Item & Produtividades $\left(\right.$ t. ha $\left.^{-1}\right)$ & $5 \%$ \\
\hline V1 & 136,76 & $\mathrm{a}$ \\
V2 & 117,32 & $\mathrm{a}$ \\
V3 & 138,73 & $\mathrm{a}$ \\
V4 & 124,94 & $\mathrm{a}$ \\
\hline
\end{tabular}

Médias seguidas por letras distintas na coluna diferem entre si, pelo teste de Tukey, ao nivel de significância, de: D.M.S. $5 \%=33,97$ t.ha ${ }^{-1}$.

Tabela 7. Valores de velocidades médias de deslocamento da colhedora em $\mathrm{km} \cdot \mathrm{h}^{-1} \mathrm{e}$ parâmetros do desempenho operacional.

\begin{tabular}{lcccccc}
\hline Item & $\begin{array}{c}\text { Velocidade } \\
\left(\mathrm{km} . \mathrm{h}^{-1}\right)\end{array}$ & $\begin{array}{c}\mathrm{CE}_{\mathrm{b}} \\
\left(\mathrm{t} . \mathrm{h}^{-1}\right)\end{array}$ & $\begin{array}{c}\mathrm{EM}_{\mathrm{t}} \\
(\%)\end{array}$ & $\begin{array}{c}\mathrm{CE}_{\mathrm{t}} \\
\left(\mathrm{t} . \mathrm{h}^{-1}\right)\end{array}$ & $\begin{array}{c}\mathrm{CC} \\
\left(1 . \mathrm{h}^{-1}\right)\end{array}$ & $\begin{array}{c}\mathrm{CC} \\
\left(\mathrm{l} \cdot \mathrm{t}^{-1}\right)\end{array}$ \\
\hline V1 & $1,70 \mathrm{c}$ & $30,64 \mathrm{c}$ & $0,86 \mathrm{~b}$ & $26,30 \mathrm{~d}$ & $97,34 \mathrm{c}$ & $3,21 \mathrm{a}$ \\
V2 & $3,37 \mathrm{c}$ & $54,31 \mathrm{C}$ & $0,91 \mathrm{a}$ & $49,61 \mathrm{c}$ & $96,23 \mathrm{c}$ & $1,77 \mathrm{~b}$ \\
V3 & $5,39 \mathrm{~b}$ & $102,08 \mathrm{~b}$ & $0,93 \mathrm{a}$ & $94,51 \mathrm{~b}$ & $103,90 \mathrm{~b}$ & $1,04 \mathrm{C}$ \\
V4 & $8,01 \mathrm{a}$ & $131,93 \mathrm{a}$ & $0,94 \mathrm{a}$ & $124,55 \mathrm{a}$ & $108,45 \mathrm{a}$ & $0,83 \mathrm{C}$ \\
D.M.S. & 0,42 & 24,31 & 0,04 & 22,57 & 2,89 & 0,49 \\
(5\%) & 4,37 & 14,52 & 2,18 & 14,58 & 1,36 & 13,56 \\
C.V. & 4,37
\end{tabular}

Médias seguidas por letras distintas na coluna diferem entre si, pelo teste de Tukey, ao nível de significância, de $5 \%$.

Tabela 8. Resumo da variância para a variável velocidade média de deslocamento da colhedora em $\mathrm{km} \cdot \mathrm{h}^{-1}$.

\begin{tabular}{lcc}
\hline Causas da Variação & G.L. & Q.M. \\
\hline Velocidade & 3 & $29,58(0,00001)$ \\
Residuo & 12 & 0,04 \\
\hline
\end{tabular}

Tabela 9. Médias das velocidades de deslocamento das colhedoras em $\mathrm{km} \cdot \mathrm{h}^{-1}$.

\begin{tabular}{ccc}
\hline Item & Velocidade $\left(\mathrm{km} \cdot \mathrm{h}^{-1}\right)$ & $5 \%$ \\
\hline V1 & 1,70 & $\mathrm{~d}$ \\
V2 & 3,37 & $\mathrm{c}$ \\
V3 & 5,39 & $\mathrm{~b}$ \\
V4 & 8,01 & $\mathrm{a}$ \\
\hline
\end{tabular}

Médias seguidas por letras distintas na coluna diferem entre si, pelo teste de Tukey, ao nivel de significância, de: D.M.S. $5 \%=0,42 \mathrm{~km} \cdot \mathrm{h}^{-1}$. 
Tabela10. Resumo da variância para a variável capacidade efetiva bruta $\left(\mathrm{CE}_{\mathrm{b}}\right) \mathrm{da}$ colhedora em $t h^{-1}$.

\begin{tabular}{lcc}
\hline Causas da Variação & G.L. & Q.M. \\
\hline Velocidade & 3 & $8374,32(0,00001)$ \\
Resíduo & 12 & 134,06 \\
\hline
\end{tabular}

Tabela 11. Médias da capacidade efetiva bruta $\left(\mathrm{CE}_{\mathrm{b}}\right)$ da colhedora em $t . \mathrm{h}^{-1}$.

\begin{tabular}{lcc}
\hline Item & $\mathrm{CE}_{\mathrm{b}}\left(\mathrm{t} . \mathrm{h}^{-1}\right)$ & $5 \%$ \\
\hline V1 & 30,64 & $\mathrm{C}$ \\
V2 & 54,31 & $\mathrm{C}$ \\
V3 & 102,08 & $\mathrm{~b}$ \\
V4 & 131,93 & $\mathrm{a}$ \\
\hline
\end{tabular}

Médias seguidas por letras distintas na coluna diferem entre si, pelo teste de Tukey, ao nivel de significância, de: D.M.S. $5 \%=24,31 \mathrm{t} \cdot \mathrm{h}^{-1}$.

Tabela 12. Resumo da variância para a variável eficácia de manipulação $\left(E M_{t}\right)$ da colhedora em \%.

\begin{tabular}{lcc}
\hline Causas da Variação & G.L. & Q.M. \\
\hline Velocidade & 3 & $0,0055(0,00054)$ \\
Residuo & 12 & 0,0004 \\
\hline
\end{tabular}

Tabela 13. Médias da eficácia de manipulação $\left(E M_{t}\right)$ da colhedora em \%.

\begin{tabular}{lcc}
\hline Item & $\mathrm{EM}_{\mathbf{t}}(\%)$ & $5 \%$ \\
\hline V1 & 0,86 & $\mathrm{~b}$ \\
V2 & 0,91 & $\mathrm{a}$ \\
V3 & 0,93 & $\mathrm{a}$ \\
V4 & 0,94 & $\mathrm{a}$ \\
\hline
\end{tabular}

Médias seguidas por letras distintas na coluna diferem entre si, pelo teste de Tukey, ao nivel de significância, de: D.M.S. $5 \%=0,042 \%$.

Tabela 14. Resumo da variância para a variável capacidade efetiva liquida $\left(C E_{1}\right)$ da colhedora em t.h ${ }^{-1}$.

\begin{tabular}{lcc}
\hline Causas da Variação & G.L. & Q.M. \\
\hline Velocidade & 3 & $7794,36(0,00001)$ \\
Residuo & 12 & 115,53 \\
\hline
\end{tabular}


Tabela 15. Médias da capacidade efetiva liquida $\left(C E_{1}\right)$ da colhedora em $t \cdot h^{-1}$.

\begin{tabular}{lcc} 
Item & $\mathrm{CE}_{\mathrm{I}}\left(\mathrm{t} . \mathrm{h}^{-1}\right)$ & $5 \%$ \\
\hline V1 & 26,30 & $\mathrm{~d}$ \\
V2 & 49,61 & $\mathrm{c}$ \\
V3 & 94,51 & $\mathrm{~b}$ \\
V4 & 124,55 & $\mathrm{a}$ \\
\hline
\end{tabular}

Médias seguidas por letras distintas na coluna diferem entre si, pelo teste de Tukey, ao nivel de significância, de: D.M.S. $5 \%=22,57 t \cdot h^{-1}$.

Tabela 16. Resumo da variância para a variável consumo de combustivel (CC) da colhedora em $1 . \mathrm{h}^{-1}$.

\begin{tabular}{lcc}
\hline Causas da Variação & G.L. & Q.M. \\
\hline Velocidade & 3 & $132,14(0,00001)$ \\
Residuo & 12 & 1,90 \\
\hline
\end{tabular}

Tabela 17. Médias do consumo de combustivel (CC) da colhedora em $1 \cdot h^{-1}$.

\begin{tabular}{lcc}
\hline Item & $\mathrm{CC}\left(1 . \mathrm{h}^{-1}\right)$ & $5 \%$ \\
\hline V1 & 97,35 & $\mathrm{c}$ \\
V2 & 96,22 & $\mathrm{C}$ \\
V3 & 103,90 & $\mathrm{~b}$ \\
V4 & 108,45 & $\mathrm{a}$ \\
\hline
\end{tabular}

Médias seguidas por letras distintas na coluna diferem entre si, pelo teste de Tukey, ao nivel de significância, de: D.M.S. $5 \%=2,89 \mathrm{I} \cdot \mathrm{h}^{-1}$.

Tabela 18. Resumo da variância para a variável consumo de combustível (CC) da colhedora em $1 . \mathrm{t}^{-1}$.

\begin{tabular}{lcc}
\hline Causas da Variação & G.L. & Q.M. \\
\hline Velocidade & 3 & $4,64(0,00001)$ \\
Residuo & 12 & 0,05 \\
\hline
\end{tabular}

Tabela 19. Médias do consumo de combustível (CC) da colhedora em I. $\mathrm{t}^{-1}$.

\begin{tabular}{lcc}
\hline Item & $\mathrm{CC}\left(\mathrm{l} . \mathrm{t}^{-1}\right)$ & $5 \%$ \\
\hline V1 & 3,21 & $\mathrm{a}$ \\
V2 & 1,77 & $\mathrm{~b}$ \\
V3 & 1,04 & $\mathrm{C}$ \\
V4 & 0,83 & $\mathrm{c}$ \\
\hline
\end{tabular}

Médias seguidas por letras distintas na coluna diferem entre si, pelo teste de Tukey, ao nivel de significância, de: D.M.S. $5 \%=0,491 \cdot \mathrm{t}^{-1}$. 
Tabela 20. Capacidade operacional (CO) em t. $h^{-1}$, como função das eficiências de $45,55,65, e, 75 \%$.

\begin{tabular}{cccccc}
\hline \multirow{2}{*}{ Velocidade } & \multirow{2}{*}{$\mathrm{CE}_{\mathrm{b}}\left(\mathrm{km} \cdot \mathrm{h}^{-1}\right)$} & \multicolumn{5}{c}{$\mathrm{CO}\left(\mathrm{t} . \mathrm{h}^{-1}\right)$} \\
& & $45 \%$ & $55 \%$ & $65 \%$ & $75 \%$ \\
\hline V1 & 30,64 & 13,79 & 16,85 & 19,92 & 22,98 \\
V2 & 54,31 & 24,44 & 29,87 & 35,30 & 40,73 \\
V3 & 102,08 & 45,94 & 56,14 & 66,35 & 76,56 \\
V4 & 131,93 & 59,37 & 72,56 & 85,75 & 98,95 \\
\hline
\end{tabular}

Tabela 21. Resumo da variância para a variável, colmos e suas frações (CF) deixadas no campo após o trabalho da colhedora, em \%.

\begin{tabular}{lcc} 
Causas da Variação & G.L. & Q.M. \\
\hline Velocidade & 3 & $2,06(0,31731)$ \\
Residuo & 12 & 1,57 \\
\hline
\end{tabular}

Tabela 22. Médias de colmos e suas frações (CF) deixadas no campo após o trabalho da colhedora, em \%.

\begin{tabular}{lcc}
\hline Item & CF $(\%)$ & $5 \%$ \\
\hline V1 & 4,18 & a \\
V2 & 0,00 & a \\
V3 & 0,00 & a \\
V4 & 2,09 & a \\
\hline
\end{tabular}

Médias seguidas por letras distintas na coluna diferem entre si, pelo teste de Tukey, ao nível de significância, de: D.M.S. $5 \%=2,63 \%$.

Tabela 23. Resumo da variância para a variável, rebolos inteiros (RI) deixadas no campo após o trabalho da colhedora, em \%.

\begin{tabular}{lcc}
\hline Causas da Variação & G.L. & Q.M. \\
\hline Velocidade & 3 & $31,91(0,58170)$ \\
Resíduo & 12 & 46,71 \\
\hline
\end{tabular}

Tabela 24. Médias de rebolos inteiros (RI) deixadas no campo após o trabalho da colhedora, em \%.

\begin{tabular}{lcc}
\hline Item & RI (\%) & $5 \%$ \\
\hline V1 & 17,94 & a \\
V2 & 20,11 & a \\
V3 & 22,82 & a \\
V4 & 24,29 & a \\
\hline
\end{tabular}

Médias seguidas por letras distintas na coluna diferem entre si, pelo teste de Tukey, ao nível de significância, de: D.M.S.5\%=14,35\%. 
Tabela 25. Resumo da variância para a variável, frações de rebolos (RF) deixadas no campo após o trabalho da colhedora, em \%.

\begin{tabular}{lcc}
\hline Causas da Variação & G.L. & Q.M. \\
\hline Velocidade & 3 & $238,29(0,12143)$ \\
Resíduo & 12 & 100,62 \\
\hline
\end{tabular}

Tabela 26. Médias de frações de rebolos (RF) deixadas no campo após o trabalho da colhedora, em \%.

\begin{tabular}{lcc}
\hline Item & RF (\%) & $5 \%$ \\
\hline V1 & 68,33 & $a$ \\
V2 & 67,16 & $a$ \\
V3 & 61,01 & $a$ \\
V4 & 51,47 & a \\
\hline
\end{tabular}

Médias seguidas por letras distintas na coluna diferem entre si, pelo teste de Tukey, ao nível de significância, de: D.M.S. $5 \%=21,06 \%$.

Tabela 27. Resumo da variância para a variável, rebolos na soqueira (RS) deixadas no campo após o trabalho da colhedora, em \%.

\begin{tabular}{lcc} 
Causas da Variação & G.L. & Q.M. \\
\hline Velocidade & 3 & $2,48(0,36120)$ \\
Residuo & 12 & 2,11 \\
\hline
\end{tabular}

Tabela 28. Médias de rebolos na soqueira (RS) deixadas no campo após o trabalho da colhedora, em \%.

\begin{tabular}{lcc}
\hline Item & RS $(\%)$ & $5 \%$ \\
\hline V1 & 5,72 & a \\
V2 & 12,54 & a \\
V3 & 11,37 & a \\
V4 & 18,96 & a \\
\hline
\end{tabular}

Médias seguidas por letras distintas na coluna diferem entre si, pelo teste de Tukey, ao nível de significância, de: D.M.S. $5 \%=3,05 \%$.

Tabela 29. Resumo da variância para a variável, raizes $(\mathrm{RC})$ deixadas no campo após o trabalho da colhedora, em \%.

\begin{tabular}{lcc}
\hline Causas da Variação & G.L. & Q.M. \\
\hline Velocidade & 3 & $0,05(0,29481)$ \\
Residuo & 12 & 0,04 \\
\hline
\end{tabular}


Tabela 30. Médias de raizes (RC) deixadas no campo após o trabalho da colhedora, em $\%$.

\begin{tabular}{lcc}
\hline Item & $\mathrm{RC}(\%)$ & $5 \%$ \\
\hline V1 & 0,29 & $\mathrm{a}$ \\
V2 & 0,11 & $\mathrm{a}$ \\
V3 & 0,44 & $\mathrm{a}$ \\
V4 & 0,00 & $\mathrm{a}$ \\
\hline
\end{tabular}

Médias seguidas por letras distintas na coluna diferem entre si, pelo teste de Tukey, ao nivel de significância, de: D.M.S. $5 \%=0,42 \%$.

Tabela 31. Resumo da variância para a variável, perda total $\left(\mathrm{PT}_{\mathrm{c}}\right)$ deixadas no campo após o trabalho da colhedora, em \%.

\begin{tabular}{lcc}
\hline Causas da Variação & G.L. & Q.M. \\
\hline Velocidade & 3 & $43,84(0,00576)$ \\
Residuo & 12 & 6,22 \\
\hline
\end{tabular}

Tabela 32. Médias de perda total ( $P T_{C}$ ) deixadas no campo após o trabalho da colhedora, em \%.

\begin{tabular}{lcc}
\hline Item & $\mathrm{PT}_{\mathrm{c}}(\%)$ & $5 \%$ \\
\hline V1 & 14,18 & $\mathrm{a}$ \\
V2 & 8,67 & $\mathrm{bc}$ \\
V3 & 7,46 & $\mathrm{c}$ \\
V4 & 13,21 & $\mathrm{ab}$ \\
\hline
\end{tabular}

Médias seguidas por letras distintas na coluna diferem entre si, pelo teste de Tukey, ao nível de significância, de: D.M.S. $5 \%=5,24 \%$.

Tabela 33. Resumo da variância para a variável, índice de ponteiros (IP) recolhida no veículo de transporte, em $\%$.

\begin{tabular}{lcc}
\hline Causas da Variação & G.L. & Q.M. \\
\hline Velocidade & 3 & $0,19(0,22322)$ \\
Resíduo & 12 & 0,11 \\
\hline
\end{tabular}


Tabela 34. Médias do índice de ponteiros (IP) recolhida no veículo de transporte, em $\%$.

\begin{tabular}{lcc}
\hline Item & IP $(\%)$ & $5 \%$ \\
\hline V1 & 5,94 & $a$ \\
V2 & 5,46 & $a$ \\
V3 & 3,66 & $a$ \\
V4 & 4,98 & a \\
\hline
\end{tabular}

Médias seguidas por letras distintas na coluna diferem entre si, pelo teste de Tukey, ao nível de significância, de: D.M.S. $5 \%=0,70 \%$.

Tabela 35. Resumo da variância para a variável, índice de folhas verdes $\left(\mathrm{IF}_{\mathrm{v}}\right)$ recolhida no veículo de transporte, em \%.

\begin{tabular}{lcc} 
Causas da Variação & G.L. & Q.M. \\
\hline Velocidade & 3 & $0,02(0,95941)$ \\
Residuo & 12 & 0,18 \\
\hline
\end{tabular}

Tabela 36. Médias do indice de folhas verdes $\left(\mathrm{IF}_{\mathrm{v}}\right)$ recolhida no veículo de transporte, em $\%$.

\begin{tabular}{lcc}
\hline Item & $\mathrm{IF}_{\mathrm{V}}(\%)$ & $5 \%$ \\
\hline V1 & 1,20 & $\mathrm{a}$ \\
V2 & 1,05 & $\mathrm{a}$ \\
V3 & 0,83 & $\mathrm{a}$ \\
V4 & 1,13 & $\mathrm{a}$ \\
\hline
\end{tabular}

Médias seguidas por letras distintas na coluna diferem entre si, pelo teste de Tukey, ao nivel de significância, de: D.M.S. $5 \%=0,88 \%$.

Tabela 37. Resumo da variância para a variável, índice de palhas $\left(\mathrm{IP}_{\mathrm{a}}\right)$ recolhida no veículo de transporte, em $\%$.

\begin{tabular}{lcc}
\hline Causas da Variação & G.L. & Q.M. \\
\hline Velocidade & 3 & $0,10(0,02518)$ \\
Residuo & 12 & 0,02 \\
\hline
\end{tabular}

Tabela 38. Médias do índice de palhas $\left(\mathrm{IP}_{\mathrm{a}}\right)$ recolhida no veículo de transporte, em \%.

\begin{tabular}{lcc}
\hline Item & $\mathrm{IP}_{\mathbf{a}}(\%)$ & $5 \%$ \\
\hline V1 & 0,27 & $\mathrm{a}$ \\
V2 & 0,20 & $\mathrm{ab}$ \\
$\mathrm{V} 3$ & 0,50 & $\mathrm{ab}$ \\
$\mathrm{V} 4$ & 0,92 & $\mathrm{~b}$ \\
\hline
\end{tabular}

Médias seguidas por letras distintas na coluna diferem entre si, pelo teste de Tukey, ao nivel de significância, de: D.M.S. $5 \%=0,32 \%$. 
Tabela 39. Resumo da variância para a variável, índice de raiz (IR) recolhida no veículo de transporte, em \%.

\begin{tabular}{lcc}
\hline Causas da Variação & G.L. & Q.M. \\
\hline Velocidade & 3 & $0,30(0,42772)$ \\
Residuo & 12 & 0,30 \\
\hline
\end{tabular}

Tabela 40. Médias do índice de raiz (IR) recolhida no veículo de transporte, em \%.

\begin{tabular}{lcc} 
Item & IR $(\%)$ & $5 \%$ \\
\hline V1 & 0,00 & $\mathrm{a}$ \\
V2 & 0,00 & $\mathrm{a}$ \\
V3 & 0,00 & $\mathrm{a}$ \\
V4 & 0,55 & $\mathrm{a}$ \\
\hline
\end{tabular}

Médias seguidas por letras distintas na coluna diferem entre si, pelo teste de Tukey, ao nivel de significância, de: D.M.S. $5 \%=1,15 \%$.

Tabela 41. Resumo da variância para a variável, índice de matéria estranha vegetal (IV) recolhida no veículo de transporte, em \%.

\begin{tabular}{lcc}
\hline Causas da Variação & G.L. & Q.M. \\
\hline Velocidade & 3 & $0,23(0,16827)$ \\
Residuo & 12 & 0,12 \\
\hline
\end{tabular}

Tabela 42. Médias do índice de matéria estranha vegetal (IV) recolhida no veículo de transporte, em \%.

\begin{tabular}{lcc}
\hline Item & IV $(\%)$ & $5 \%$ \\
\hline V1 & 7,72 & $a$ \\
V2 & 6,80 & $a$ \\
V3 & 5,04 & $a$ \\
V4 & 7,73 & a \\
\hline
\end{tabular}

Médias seguidas por letras distintas na coluna diferem entre si, pelo teste de Tukey, ao nivel de significância, de: D.M.S. $5 \%=0,72 \%$.

Tabela 43. Resumo da variância para a variável, indice de matéria estranha mineral (IM) recolhida no veiculo de transporte, em \%.

\begin{tabular}{lcc} 
Causas da Variação & G.L. & Q.M. \\
\hline Velocidade & 3 & $0,78(0,40390)$ \\
Residuo & 12 & 0,74 \\
\hline
\end{tabular}


Tabela 44. Médias do índice de matéria estranha mineral (IM) recolhida no veículo de transporte, em \%.

\begin{tabular}{lcc}
\hline Item & IM (\%) & $5 \%$ \\
\hline V1 & 0,88 & $\mathrm{a}$ \\
V2 & 0,00 & $\mathrm{a}$ \\
V3 & 0,00 & $\mathrm{a}$ \\
V4 & 0,00 & $\mathrm{a}$ \\
\hline
\end{tabular}

Médias seguidas por letras distintas na coluna diferem entre si, pelo teste de Tukey, ao nivel de significância, de: D.M.S. $5 \%=1,80 \%$.

Tabela 45. Resumo da variância para a variável, índice de matéria estranha total (IT) recolhida no veículo de transporte, em \%.

\begin{tabular}{lcc} 
Causas da Variação & G.L. & Q.M. \\
\hline Velocidade & 3 & $0,31(0,18575)$ \\
Residuo & 12 & 0,16 \\
\hline
\end{tabular}

Tabela 46. Médias do índice de matéria estranha total (IT) recolhida no veiculo de transporte, em \%.

\begin{tabular}{lcc}
\hline Item & IT $(\%)$ & $5 \%$ \\
\hline V1 & 8,47 & a \\
V2 & 6,80 & a \\
V3 & 5,04 & a \\
V4 & 7,72 & a \\
\hline
\end{tabular}

Médias seguidas por letras distintas na coluna diferem entre si, pelo teste de Tukey, ao nível de significância, de: D.M.S. $5 \%=0,85 \%$.

Tabela 47. Resumo da variância para a variável, da qualidade tecnológica, Brix \% caldo, após a colheita.

\begin{tabular}{lcc}
\hline Causas da Variação & G.L. & Q.M. \\
\hline Velocidade & 3 & $0,39(0,63414)$ \\
Residuo & 12 & 0,66 \\
\hline
\end{tabular}

Tabela 48. Médias do, Brix \% caldo, após a colheita, em \%.

\begin{tabular}{lcc}
\hline Item & Brix caldo (\%) & $5 \%$ \\
\hline V1 & 17,27 & $\mathrm{a}$ \\
V2 & 17,02 & $\mathrm{a}$ \\
V3 & 17,12 & $\mathrm{a}$ \\
V4 & 16,55 & $\mathrm{a}$ \\
\hline
\end{tabular}

Médias seguidas por letras distintas na coluna diferem entre si, pelo teste de Tukey, ao nivel de significância, de: D.M.S. $5 \%=1,71 \%$. 
Tabela 49. Resumo da variância para a variável, da qualidade tecnológica, Pol \% caldo, após a colheita.

\begin{tabular}{lcc}
\hline Causas da Variação & G.L. & Q.M. \\
\hline Velocidade & 3 & $0,48(0,55237)$ \\
Resíduo & 12 & 0,65 \\
\hline
\end{tabular}

Tabela 50. Médias do, Pol \% caldo, após a colheita.

\begin{tabular}{lcc} 
Item & Pol caldo $(\%)$ & $5 \%$ \\
\hline V1 & 14,22 & $\mathrm{a}$ \\
V2 & 14,24 & $\mathrm{a}$ \\
V3 & 14,40 & $\mathrm{a}$ \\
V4 & 13,61 & $\mathrm{a}$ \\
\hline
\end{tabular}

Médias seguidas por letras distintas na coluna diferem entre si, pelo teste de Tukey, ao nível de significância, de: D.M.S. $5 \%=1,69 \%$.

Tabela 51. Resumo da variância para a variável, da qualidade tecnológica, Pureza \% caldo, após a colheita.

\begin{tabular}{lcc}
\hline Causas da Variação & G.L. & Q.M. \\
\hline Velocidade & 3 & $3,80(0,26631)$ \\
Residuo & 12 & 2,55 \\
\hline
\end{tabular}

Tabela 52. Médias do, Pureza \% caldo, após a colheita.

\begin{tabular}{lcc}
\hline Item & Pureza caldo $(\%)$ & $5 \%$ \\
\hline V1 & 82,22 & $\mathrm{a}$ \\
V2 & 83,67 & $\mathrm{a}$ \\
V3 & 84,07 & $\mathrm{a}$ \\
V4 & 82,18 & $\mathrm{a}$ \\
\hline
\end{tabular}

Médias seguidas por letras distintas na coluna diferem entre si, pelo teste de Tukey, ao nível de significância, de: D.M.S.5\%=3,35\%.

Tabela 53. Resumo da variância para a variável, da qualidade tecnológica, Fibra \% cana, após a colheita.

\begin{tabular}{lcc}
\hline Causas da Variação & G.L. & Q.M. \\
\hline Velocidade & 3 & $0,65(0,52517)$ \\
Resíduo & 12 & 0,83 \\
\hline
\end{tabular}


Tabela 54. Médias do, Fibra \% cana, após a colheita.

\begin{tabular}{ccc} 
Item & Fibra cana $(\%)$ & $5 \%$ \\
\hline V1 & 13,39 & $\mathrm{a}$ \\
V2 & 12,91 & $\mathrm{a}$ \\
V3 & 12,86 & $\mathrm{a}$ \\
V4 & 12,91 & $\mathrm{a}$ \\
\hline
\end{tabular}

Médias seguidas por letras distintas na coluna diferem entre si, pelo teste de Tukey, ao nivel de significância, de: D.M.S. $5 \%=1,91 \%$.

Tabela 55. Resumo da variância para a variável, da qualidade tecnológica, Pol \% cana, após a colheita.

\begin{tabular}{lcc}
\hline Causas da Variação & G.L. & Q.M. \\
\hline Velocidade & 3 & $0,42(0,50452)$ \\
Resíduo & 12 & 0,49 \\
\hline
\end{tabular}

Tabela 56. Médias do, Pol \% cana, após a colheita.

\begin{tabular}{lcc} 
Item & Pol cana $(\%)$ & $5 \%$ \\
\hline V1 & 11,98 & $\mathrm{a}$ \\
V2 & 11,98 & $\mathrm{a}$ \\
V3 & 12,01 & $\mathrm{a}$ \\
V4 & 11,34 & $\mathrm{a}$ \\
\hline
\end{tabular}

Médias seguidas por letras distintas na coluna diferem entre si, pelo teste de Tukey, ao nível de significância, de: D.M.S. $5 \%=1,48 \%$.

Tabela 57. Resumo da variância para a variável, da qualidade tecnológica, Terra \% cana, após a colheita.

\begin{tabular}{lcc}
\hline Causas da Variação & G.L. & Q.M. \\
\hline Velocidade & 3 & $3,84(0,42645)$ \\
Resíduo & 12 & 3,83 \\
\hline
\end{tabular}

Tabela 58. Médias do, Terra \% cana, após a colheita.

\begin{tabular}{lcc}
\hline Item & Terra cana $(\%)$ & $5 \%$ \\
\hline V1 & 0,70 & $\mathrm{a}$ \\
V2 & 1,90 & $\mathrm{a}$ \\
V3 & 1,82 & $\mathrm{a}$ \\
V4 & 3,10 & $\mathrm{a}$ \\
\hline
\end{tabular}

Médias seguidas por letras distintas na coluna diferem entre si, pelo teste de Tukey, ao nivel de significância, de: D.M.S. $5 \%=4,11 \%$. 
Tabela 59. Fluxo de caixa para a colhedora em US\$, na capacidade operacional da V1, com a eficiência adotada de $45 \%$.

\begin{tabular}{lrrrrrrr} 
Ano $(t)$ & \multicolumn{1}{c}{1} & \multicolumn{1}{c}{2} & \multicolumn{1}{c}{3} & \multicolumn{1}{c}{4} & \multicolumn{1}{c}{5} & \multicolumn{1}{c}{6} & \multicolumn{1}{c}{ Total } \\
\hline Valor residual & 259250,00 & 213500,00 & 167750,00 & 122000,00 & 76250,00 & 30500,00 & \multicolumn{1}{c}{-} \\
Depreciação & 45750,00 & 45750,00 & 45750,00 & 45750,00 & 45750,00 & 45750,00 & 274500,00 \\
Juros & 36600,00 & 31110,00 & 25620,00 & 20130,00 & 14640,00 & 9150,00 & 137250,00 \\
Seguro & 3172,00 & 2696,20 & 2220,40 & 1744,60 & 1268,80 & 793,00 & 11895,00 \\
Alojamento \& Adm. & 991,25 & 991,25 & 991,25 & 991,25 & 991,25 & 991,25 & 5947,50 \\
Combustivel & 32290,51 & 32290,51 & 32290,51 & 32290,51 & 32290,51 & 32290,51 & 193743,05 \\
Óleo lubrificante & 617,40 & 617,40 & 617,40 & 617,40 & 617,40 & 617,40 & 3704,40 \\
Óleo hidráulico & 2022,06 & 2022,06 & 2022,06 & 2022,06 & 2022,06 & 2022,06 & 12132,37 \\
Comb.Ma.\& Abast. & 6048,00 & 6048,00 & 6048,00 & 6048,00 & 6048,00 & 6048,00 & 36288,00 \\
Peças Reposição & 38416,00 & 41123,00 & 36432,00 & 43826,00 & 52027,00 & 37685,00 & 249509,00 \\
Serviços mec. & 4977,00 & 4977,00 & 4977,00 & 4977,00 & 4977,00 & 4977,00 & 29862,00 \\
Sal Oper. & 6615,00 & 6615,00 & 6615,00 & 6615,00 & 6615,00 & 6615,00 & 39690,00 \\
Total Geral & & & & & & & 994521,32 \\
\hline
\end{tabular}

Valor da colhedora nova $(V): 305.000,00$. Valor de revenda $\left(V R_{6}\right): 30.500,00$

Tabela 60. Fluxo de caixa para a colhedora em US\$, na capacidade operacional da V1, com a eficiência adotada de $55 \%$.

\begin{tabular}{lrrrrrrr} 
Ano (t) & \multicolumn{1}{c}{2} & \multicolumn{1}{c}{2} & \multicolumn{1}{c}{3} & \multicolumn{1}{c}{4} & \multicolumn{1}{c}{5} & \multicolumn{1}{c}{6} & \multicolumn{1}{c}{ Total } \\
\hline Valor residual & 259250,00 & 213500,00 & 167750,00 & 122000,00 & 76250,00 & 30500,00 & \multicolumn{1}{c}{-} \\
Depreciação & 45750,00 & 45750,00 & 45750,00 & 45750,00 & 45750,00 & 45750,00 & 274500,00 \\
Juros & 36600,00 & 31110,00 & 25620,00 & 20130,00 & 14640,00 & 9150,00 & 137250,00 \\
Seguro & 3172,00 & 2696,20 & 2220,40 & 1744,60 & 1268,80 & 793,00 & 11895,00 \\
Alojamento \& Adm. & 991,25 & 991,25 & 991,25 & 991,25 & 991,25 & 991,25 & 5947,50 \\
Combustivel & 39466,18 & 39466,18 & 39466,18 & 39466,18 & 39466,18 & 39466,18 & 236797,06 \\
Óleo lubrificante & 617,40 & 617,40 & 617,40 & 617,40 & 617,40 & 617,40 & 3704,40 \\
Óleo hidráulico & 2470,76 & 2470,76 & 2470,76 & 2470,76 & 2470,76 & 2470,76 & 14824,55 \\
Comb.Ma.\& Abast. & 6048,00 & 6048,00 & 6048,00 & 6048,00 & 6048,00 & 6048,00 & 36288,00 \\
Peças Reposição & 38416,00 & 41123,00 & 36432,00 & 43826,00 & 52027,00 & 37685,00 & 249509,00 \\
Serviços mec. & 4977,00 & 4977,00 & 4977,00 & 4977,00 & 4977,00 & 4977,00 & 29862,00 \\
Sal Oper. & 6615,00 & 6615,00 & 6615,00 & 6615,00 & 6615,00 & 6615,00 & 39690,00 \\
Total Geral & & & & & & & 1040267,51 \\
\hline
\end{tabular}

Valor da colhedora nova (VI): $305.000,00$. Valor de revenda $\left(V R_{6}\right): 30.500,00$ 
Tabela 61. Fluxo de caixa para a colhedora em US\$, na capacidade operacional da $\mathrm{V} 1$, com a eficiência adotada de $65 \%$.

\begin{tabular}{lrrrrrrr} 
Ano $(t)$ & \multicolumn{1}{c}{1} & \multicolumn{1}{c}{2} & \multicolumn{1}{c}{3} & \multicolumn{1}{c}{4} & \multicolumn{1}{c}{5} & \multicolumn{1}{c}{6} & \multicolumn{1}{c}{ Total } \\
\hline Valor residual & 259250,00 & 213500,00 & 167750,00 & 122000,00 & 76250,00 & 30500,00 & \multicolumn{1}{c}{--} \\
Depreciação & 45750,00 & 45750,00 & 45750,00 & 45750,00 & 45750,00 & 45750,00 & 274500,00 \\
Juros & 36600,00 & 31110,00 & 25620,00 & 20130,00 & 14640,00 & 9150,00 & 137250,00 \\
Seguro & 3172,00 & 2696,20 & 2220,40 & 1744,60 & 1268,80 & 793,00 & 11895,00 \\
Alojamento \& Adm. & 991,25 & 991,25 & 991,25 & 991,25 & 991,25 & 991,25 & 5947,50 \\
Combustivel & 46641,85 & 46641,85 & 46641,85 & 46641,85 & 46641,85 & 46641,85 & 279851,07 \\
Óleo lubrificante & 617,40 & 617,40 & 617,40 & 617,40 & 617,40 & 617,40 & 3704,40 \\
Óleo hidráulico & 2920,92 & 2920,92 & 2920,92 & 2920,92 & 2920,92 & 2920,92 & 17525,52 \\
Comb.Ma.\& Abast. & 6048,00 & 6048,00 & 6048,00 & 6048,00 & 6048,00 & 6048,00 & 36288,00 \\
Peças Reposição & 38416,00 & 41123,00 & 36432,00 & 43826,00 & 52027,00 & 37685,00 & 249509,00 \\
Serviços mec. & 4977,00 & 4977,00 & 4977,00 & 4977,00 & 4977,00 & 4977,00 & 29862,00 \\
Sal Oper. & 6615,00 & 6615,00 & 6615,00 & 6615,00 & 6615,00 & 6615,00 & 39690,00 \\
Total Geral & & & & & & & 1086022,49 \\
\hline Valor da Coln
\end{tabular}

Valor da colhedora nova $(V): 305.000,00$. Valor de revenda $\left(V R_{6}\right): 30.500,00$

Tabela 62. Fluxo de caixa para a colhedora em US\$, na capacidade operacional da V1, com a eficiência adotada de $75 \%$.

\begin{tabular}{lrrrrrrr} 
Ano $(t)$ & \multicolumn{1}{c}{1} & \multicolumn{1}{c}{2} & \multicolumn{1}{c}{3} & \multicolumn{1}{c}{4} & \multicolumn{1}{c}{5} & \multicolumn{1}{c}{6} & \multicolumn{1}{c}{ Total } \\
\hline Valor residual & 259250,00 & 213500,00 & 167750,00 & 122000,00 & 76250,00 & 30500,00 & \multicolumn{1}{c}{--} \\
Depreciação & 45750,00 & 45750,00 & 45750,00 & 45750,00 & 45750,00 & 45750,00 & 274500,00 \\
Juros & 36600,00 & 31110,00 & 25620,00 & 20130,00 & 14640,00 & 9150,00 & 137250,00 \\
Seguro & 3172,00 & 2696,20 & 2220,40 & 1744,60 & 1268,80 & 793,00 & 11895,00 \\
Alojamento \& Adm. & 991,25 & 991,25 & 991,25 & 991,25 & 991,25 & 991,25 & 5947,50 \\
Combustivel & 53817,51 & 53817,51 & 53817,51 & 53817,51 & 53817,51 & 53817,51 & 322905,08 \\
Óleo lubrificante & 617,40 & 617,40 & 617,40 & 617,40 & 617,40 & 617,40 & 3704,40 \\
Óleo hidráulico & 3369,61 & 3369,61 & 3369,61 & 3369,61 & 3369,61 & 3369,61 & 20217,69 \\
Comb.Ma.\& Abast. & 6048,00 & 6048,00 & 6048,00 & 6048,00 & 6048,00 & 6048,00 & 36288,00 \\
Peças Reposiçäo & 38416,00 & 41123,00 & 36432,00 & 43826,00 & 52027,00 & 37685,00 & 249509,00 \\
Serviços mec. & 4977,00 & 4977,00 & 4977,00 & 4977,00 & 4977,00 & 4977,00 & 29862,00 \\
Sal Oper. & 6615,00 & 6615,00 & 6615,00 & 6615,00 & 6615,00 & 6615,00 & 39690,00 \\
Total Geral & & & & & & & 1131768,67 \\
\hline Valor da colnt,
\end{tabular}

Valor da colhedora nova $(V): 305.000,00$. Valor de revenda $\left(V R_{6}\right): 30.500,00$ 
Tabela 63. Fluxo de caixa para a colhedora em US\$, na capacidade operacional da V2, com a eficiência adotada de $45 \%$.

\begin{tabular}{lrrrrrrr} 
Ano (t) & \multicolumn{1}{c}{ 1 } & \multicolumn{1}{c}{2} & \multicolumn{1}{c}{3} & \multicolumn{1}{c}{4} & \multicolumn{1}{c}{5} & \multicolumn{1}{c}{6} & \multicolumn{1}{c}{ Total } \\
\hline Valor residual & 259250,00 & 213500,00 & 167750,00 & 122000,00 & 76250,00 & 30500,00 & \multicolumn{1}{c}{--} \\
Depreciação & 45750,00 & 45750,00 & 45750,00 & 45750,00 & 45750,00 & 45750,00 & 274500,00 \\
Juros & 36600,00 & 31110,00 & 25620,00 & 20130,00 & 14640,00 & 9150,00 & 137250,00 \\
Seguro & 3172,00 & 2696,20 & 2220,40 & 1744,60 & 1268,80 & 793,00 & 11895,00 \\
Alojamento \& Adm. & 991,25 & 991,25 & 991,25 & 991,25 & 991,25 & 991,25 & 5947,50 \\
Combustivel & 31915,69 & 31915,69 & 31915,69 & 31915,69 & 31915,69 & 31915,69 & 191494,16 \\
Óleo lubrificante & 617,40 & 617,40 & 617,40 & 617,40 & 617,40 & 617,40 & 3704,40 \\
Óleo hidráulico & 3583,70 & 3583,70 & 3583,70 & 3583,70 & 3583,70 & 3583,70 & 21502,19 \\
Comb.Ma.\& Abast. & 6048,00 & 6048,00 & 6048,00 & 6048,00 & 6048,00 & 6048,00 & 36288,00 \\
Peças Reposição & 38416,00 & 41123,00 & 36432,00 & 43826,00 & 52027,00 & 37685,00 & 249509,00 \\
Serviços mec. & 4977,00 & 4977,00 & 4977,00 & 4977,00 & 4977,00 & 4977,00 & 29862,00 \\
Sal Oper. & 6615,00 & 6615,00 & 6615,00 & 6615,00 & 6615,00 & 6615,00 & 39690,00 \\
Total Geral & & & & & & & 1001642,25 \\
\hline Valor da Con
\end{tabular}

Valor da colhedora nova (VI): $305.000,00$. Valor de revenda $\left(V R_{6}\right): 30.500,00$

Tabela 64. Fluxo de caixa para a colhedora em US\$, na capacidade operacional da V2, com a eficiência adotada de $55 \%$.

\begin{tabular}{|c|c|c|c|c|c|c|c|}
\hline$A n o(t)$ & 1 & 2 & 3 & 4 & 5 & 6 & Total \\
\hline Valor residual & 259250,00 & 213500,00 & 167750,00 & 122000,00 & 76250,00 & 30500,00 & -- \\
\hline Depreciação & 45750,00 & 45750,00 & 45750,00 & 45750,00 & 45750,00 & 45750,00 & 274500,00 \\
\hline Juros & 36600,00 & 31110,00 & 25620,00 & 20130,00 & 14640,00 & 9150,00 & 137250,00 \\
\hline Seguro & 3172,00 & 2696,20 & 2220,40 & 1744,60 & 1268,80 & 793,00 & 11895,00 \\
\hline Alojamento \& Adm. & 991,25 & 991,25 & 991,25 & 991,25 & 991,25 & 991,25 & 5947,50 \\
\hline Combustivel & 39008,07 & 39008,07 & 39008,07 & 39008,07 & 39008,07 & 39008,07 & 234048,41 \\
\hline Óleo lubrificante & 617,40 & 617,40 & 617,40 & 617,40 & 617,40 & 617,40 & 3704,40 \\
\hline Óleo hidráulico & 4379,91 & 4379,91 & 4379,91 & 4379,91 & 4379,91 & 4379,91 & 26279,48 \\
\hline Comb.Ma.\& Abast. & 6048,00 & 6048,00 & 6048,00 & 6048,00 & 6048,00 & 6048,00 & $36288,0 \mathrm{C}$ \\
\hline Peças Reposição & 38416,00 & 41123,00 & 36432,00 & 43826,00 & 52027,00 & 37685,00 & 249509,00 \\
\hline Serviços mec. & 4977,00 & 4977,00 & 4977,00 & 4977,00 & 4977,00 & 4977,00 & $29862,0 C$ \\
\hline Sal Oper. & 6615,00 & 6615,00 & 6615,00 & 6615,00 & 6615,00 & 6615,00 & 39690,00 \\
\hline Total Geral & & & & & & & 1048973,79 \\
\hline
\end{tabular}

Valor da colhedora nova (VI): $305.000,00$. Valor de revenda $\left(V R_{6}\right): 30.500,00$ 
Tabela 65. Fluxo de caixa para a colhedora em US\$, na capacidade operacional da V2, com a eficiência adotada de $65 \%$.

\begin{tabular}{|c|c|c|c|c|c|c|c|}
\hline Ano (t) & 1 & 2 & 3 & 4 & 5 & 6 & Total \\
\hline Valor residual & 259250,00 & 213500,00 & 167750,00 & 122000,00 & 76250,00 & 30500,00 & -- \\
\hline Depreciaçāo & 45750,00 & 45750,00 & 45750,00 & 45750,00 & 45750,00 & 45750,00 & 274500,00 \\
\hline Juros & 36600,00 & 31110,00 & 25620,00 & 20130,00 & 14640,00 & 9150,00 & 137250,00 \\
\hline Seguro & 3172,00 & 2696,20 & 2220,40 & 1744,60 & 1268,80 & 793,00 & 11895,00 \\
\hline Alojamento \& Adm. & 991,25 & 991,25 & 991,25 & 991,25 & 991,25 & 991,25 & 5947,50 \\
\hline Combustivel & 46100,45 & 46100,45 & 46100,45 & 46100,45 & 46100,45 & 46100,45 & 276602,67 \\
\hline Óleo lubrificante & 617,40 & 617,40 & 617,40 & 617,40 & 617,40 & 617,40 & 3704,40 \\
\hline Óleo hidráulico & 5176,13 & 5176,13 & 5176,13 & 5176,13 & 5176,13 & 5176,13 & 6,76 \\
\hline Comb.Ma.\& Abast. & 6048,00 & 6048,00 & 6048,00 & 6048,00 & 6048,00 & 6048,00 & 36288,00 \\
\hline Peças Reposição & 38416,00 & 41123,00 & 36432,00 & 43826,00 & 52027,00 & 37685,00 & 249509,00 \\
\hline Serviços mec. & 4977,00 & 4977,00 & 4977,00 & 4977,00 & 4977,00 & 4977,00 & 29862,00 \\
\hline Sal Oper. & 6615,00 & 6615,00 & 6615,00 & 6615,00 & 6615,00 & 6615,00 & 39690,00 \\
\hline Total Geral & & & & & & & 1096305,34 \\
\hline
\end{tabular}

Valor da colhedora nova $(V): 305.000,00$. Valor de revenda $\left(V R_{6}\right): 30.500,00$

Tabela 66. Fluxo de caixa para a colhedora em US\$, na capacidade operacional da V2, com a eficiência adotada de $75 \%$.

\begin{tabular}{lrrrrrrr} 
Ano (t) & \multicolumn{1}{c}{$\mathbf{1}$} & \multicolumn{1}{c}{2} & \multicolumn{1}{c}{3} & \multicolumn{1}{c}{4} & \multicolumn{1}{c}{5} & \multicolumn{1}{c}{6} & \multicolumn{1}{c}{ Total } \\
\hline Valor residual & 259250,00 & 213500,00 & 167750,00 & 122000,00 & 76250,00 & 30500,00 & \multicolumn{1}{c}{-} \\
Depreciação & 45750,00 & 45750,00 & 45750,00 & 45750,00 & 45750,00 & 45750,00 & 274500,00 \\
Juros & 36600,00 & 31110,00 & 25620,00 & 20130,00 & 14640,00 & 9150,00 & 137250,00 \\
Seguro & 3172,00 & 2696,20 & 2220,40 & 1744,60 & 1268,80 & 793,00 & 11895,00 \\
Allojamento \& Adm. & 991,25 & 991,25 & 991,25 & 991,25 & 991,25 & 991,25 & 5947,50 \\
Combustível & 53192,82 & 53192,82 & 53192,82 & 53192,82 & 53192,82 & 53192,82 & 319156,93 \\
Óleo lubrificante & 617,40 & 617,40 & 617,40 & 617,40 & 617,40 & 617,40 & 3704,40 \\
Óleo hidráulico & 5972,34 & 5972,34 & 5972,34 & 5972,34 & 5972,34 & 5972,34 & 35834,05 \\
Comb.Ma.\& Abast. & 6048,00 & 6048,00 & 6048,00 & 6048,00 & 6048,00 & 6048,00 & 36288,00 \\
Peças Reposição & 38416,00 & 41123,00 & 36432,00 & 43826,00 & 52027,00 & 37685,00 & 249509,00 \\
Serviços mec. & 4977,00 & 4977,00 & 4977,00 & 4977,00 & 4977,00 & 4977,00 & 29862,00 \\
Sal Oper. & 6615,00 & 6615,00 & 6615,00 & 6615,00 & 6615,00 & 6615,00 & 39690,00 \\
Total Geral & & & & & & & 1143636,88 \\
\hline Valor da Colhed
\end{tabular}

Valor da colhedora nova (VI): $305.000,00$. Valor de revenda $\left(V R_{6}\right): 30.500,00$ 
Tabela 67. Fluxo de caixa para a colhedora em US\$, na capacidade operacional da V3, com a eficiência adotada de $45 \%$.

\begin{tabular}{lrrrrrrr} 
Ano (t) & \multicolumn{1}{c}{$\mathbf{1}$} & \multicolumn{1}{c}{2} & \multicolumn{1}{c}{3} & \multicolumn{1}{c}{4} & \multicolumn{1}{c}{5} & \multicolumn{1}{c}{6} & \multicolumn{1}{c}{ Total } \\
\hline Valor residual & 259250,00 & 213500,00 & 167750,00 & 122000,00 & 76250,00 & 30500,00 & \multicolumn{1}{c}{-} \\
Depreciação & 45750,00 & 45750,00 & 45750,00 & 45750,00 & 45750,00 & 45750,00 & 274500,00 \\
Juros & 36600,00 & 31110,00 & 25620,00 & 20130,00 & 14640,00 & 9150,00 & 137250,00 \\
Seguro & 3172,00 & 2696,20 & 2220,40 & 1744,60 & 1268,80 & 793,00 & 11895,00 \\
Alojamento \& Adm. & 991,25 & 991,25 & 991,25 & 991,25 & 991,25 & 991,25 & 5947,50 \\
Combustivel & 34463,11 & 34463,11 & 34463,11 & 34463,11 & 34463,11 & 34463,11 & 206778,66 \\
Óleo lubrificante & 617,40 & 617,40 & 617,40 & 617,40 & 617,40 & 617,40 & 3704,40 \\
Óleo hidráulico & 6736,30 & 6736,30 & 6736,30 & 6736,30 & 6736,30 & 6736,30 & 40417,78 \\
Comb.Ma.\& Abast. & 6048,00 & 6048,00 & 6048,00 & 6048,00 & 6048,00 & 6048,00 & 36288,00 \\
Peças Reposição & 38416,00 & 41123,00 & 36432,00 & 43826,00 & 52027,00 & 37685,00 & 249509,00 \\
Serviços mec. & 4977,00 & 4977,00 & 4977,00 & 4977,00 & 4977,00 & 4977,00 & 29862,00 \\
Sal Oper. & 6615,00 & 6615,00 & 6615,00 & 6615,00 & 6615,00 & 6615,00 & 39690,00 \\
Total Geral & & & & & & & 1035842,35 \\
\hline Valor da Colm
\end{tabular}

Valor da colhedora nova (VI): $305.000,00$. Valor de revenda $\left(V R_{6}\right): 30.500,00$

Tabela 68. Fluxo de caixa para a colhedora em US\$, na capacidade operacional da V3, com a eficiência adotada de $55 \%$.

\begin{tabular}{lrrrrrrr} 
Ano (t) & \multicolumn{1}{c}{$\mathbf{1}$} & \multicolumn{1}{c}{$\mathbf{2}$} & \multicolumn{1}{c}{3} & \multicolumn{1}{c}{4} & \multicolumn{1}{c}{5} & \multicolumn{1}{c}{6} & \multicolumn{1}{c}{ Total } \\
\hline Valor residual & 259250,00 & 213500,00 & 167750,00 & 122000,00 & 76250,00 & 30500,00 & \multicolumn{1}{c}{-} \\
Depreciaçăo & 45750,00 & 45750,00 & 45750,00 & 45750,00 & 45750,00 & 45750,00 & 274500,00 \\
Juros & 36600,00 & 31110,00 & 25620,00 & 20130,00 & 14640,00 & 9150,00 & 137250,00 \\
Seguro & 3172,00 & 2696,20 & 2220,40 & 1744,60 & 1268,80 & 793,00 & 11895,00 \\
Alojamento \& Adm. & 991,25 & 991,25 & 991,25 & 991,25 & 991,25 & 991,25 & 5947,50 \\
Combustivel & 42121,58 & 42121,58 & 42121,58 & 42121,58 & 42121,58 & 42121,58 & 252729,48 \\
Óleo lubrificante & 617,40 & 617,40 & 617,40 & 617,40 & 617,40 & 617,40 & 3704,40 \\
Óleo hidráulico & 8231,95 & 8231,95 & 8231,95 & 8231,95 & 8231,95 & 8231,95 & 49391,69 \\
Comb.Ma.\& Abast. & 6048,00 & 6048,00 & 6048,00 & 6048,00 & 6048,00 & 6048,00 & 36288,00 \\
Peças Reposiçāo & 38416,00 & 41123,00 & 36432,00 & 43826,00 & 52027,00 & 37685,00 & 249509,00 \\
Serviços mec. & 4977,00 & 4977,00 & 4977,00 & 4977,00 & 4977,00 & 4977,00 & 29862,00 \\
Sal Oper. & 6615,00 & 6615,00 & 6615,00 & 6615,00 & 6615,00 & 6615,00 & 39690,00 \\
Total Geral & & & & & & & 1090767,07 \\
\hline Valor da colhed
\end{tabular}

Valor da colhedora nova $(V): 305.000,00$. Valor de revenda $\left(V R_{6}\right): 30.500,00$ 
Tabela 69. Fluxo de caixa para a colhedora em US\$, na capacidade operacional da V3, com a eficiência adotada de $65 \%$.

\begin{tabular}{lrrrrrrr} 
Ano $(t)$ & \multicolumn{1}{c}{$\mathbf{1}$} & \multicolumn{1}{c}{2} & \multicolumn{1}{c}{3} & \multicolumn{1}{c}{4} & \multicolumn{1}{c}{5} & \multicolumn{1}{c}{6} & \multicolumn{1}{c}{ Total } \\
\hline Valor residual & 259250,00 & 213500,00 & 167750,00 & 122000,00 & 76250,00 & 30500,00 & \multicolumn{1}{c}{--} \\
Depreciação & 45750,00 & 45750,00 & 45750,00 & 45750,00 & 45750,00 & 45750,00 & 274500,00 \\
Juros & 36600,00 & 31110,00 & 25620,00 & 20130,00 & 14640,00 & 9150,00 & 137250,00 \\
Seguro & 3172,00 & 2696,20 & 2220,40 & 1744,60 & 1268,80 & 793,00 & 11895,00 \\
Alojamento \& Adm. & 991,25 & 991,25 & 991,25 & 991,25 & 991,25 & 991,25 & 5947,50 \\
Combustivel & 49780,05 & 49780,05 & 49780,05 & 49780,05 & 49780,05 & 49780,05 & 298680,29 \\
Óleo lubrificante & 617,40 & 617,40 & 617,40 & 617,40 & 617,40 & 617,40 & 3704,40 \\
Óleo hidráulico & 9729,07 & 9729,07 & 9729,07 & 9729,07 & 9729,07 & 9729,07 & 58374,40 \\
Comb.Ma.\& Abast. & 6048,00 & 6048,00 & 6048,00 & 6048,00 & 6048,00 & 6048,00 & 36288,00 \\
Peças Reposição & 38416,00 & 41123,00 & 36432,00 & 43826,00 & 52027,00 & 37685,00 & 249509,00 \\
Serviços mec. & 4977,00 & 4977,00 & 4977,00 & 4977,00 & 4977,00 & 4977,00 & 29862,00 \\
Sal Oper. & 6615,00 & 6615,00 & 6615,00 & 6615,00 & 6615,00 & 6615,00 & 39690,00 \\
Total Geral & & & & & & & 1145700,59 \\
\hline Valo da Colh
\end{tabular}

Valor da colhedora nova (VI): $305.000,00$. Valor de revenda (VR6): $30.500,00$

Tabela 70 . Fluxo de caixa para a colhedora em US\$, na capacidade operacional da V3, com a eficiência adotada de $75 \%$.

\begin{tabular}{lrrrrrrr} 
Ano $(t)$ & \multicolumn{1}{c}{$\mathbf{1}$} & \multicolumn{1}{c}{2} & \multicolumn{1}{c}{3} & \multicolumn{1}{c}{4} & \multicolumn{1}{c}{5} & \multicolumn{1}{c}{6} & \multicolumn{1}{c}{ Total } \\
\hline Valor residual & 259250,00 & 213500,00 & 167750,00 & 122000,00 & 76250,00 & 30500,00 & \multicolumn{1}{c}{-} \\
Depreciação & 45750,00 & 45750,00 & 45750,00 & 45750,00 & 45750,00 & 45750,00 & 274500,00 \\
Juros & 36600,00 & 31110,00 & 25620,00 & 20130,00 & 14640,00 & 9150,00 & 137250,00 \\
Seguro & 3172,00 & 2696,20 & 2220,40 & 1744,60 & 1268,80 & 793,00 & 11895,00 \\
Alojamento \& Adm. & 991,25 & 991,25 & 991,25 & 991,25 & 991,25 & 991,25 & 5947,50 \\
Combustivel & 57438,52 & 57438,52 & 57438,52 & 57438,52 & 57438,52 & 57438,52 & 344631,11 \\
Óleo lubrificante & 617,40 & 617,40 & 617,40 & 617,40 & 617,40 & 617,40 & 3704,40 \\
Óleo hidráulico & 11226,18 & 11226,18 & 11226,18 & 11226,18 & 11226,18 & 11226,18 & 67357,11 \\
Comb.Ma.\& Abast. & 6048,00 & 6048,00 & 6048,00 & 6048,00 & 6048,00 & 6048,00 & 36288,00 \\
Peças Reposição & 38416,00 & 41123,00 & 36432,00 & 43826,00 & 52027,00 & 37685,00 & 249509,00 \\
Serviços mec. & 4977,00 & 4977,00 & 4977,00 & 4977,00 & 4977,00 & 4977,00 & 29862,00 \\
Sal Oper. & 6615,00 & 6615,00 & 6615,00 & 6615,00 & 6615,00 & 6615,00 & 39690,00 \\
Total Geral & & & & & & & 1200634,11 \\
\hline Valor da Colned
\end{tabular}

Valor da colhedora nova $(V): 305.000,00$. Valor de revenda $\left(V R_{6}\right): 30.500,00$ 
Tabela 71. Fluxo de caixa para a colhedora em US\$, na capacidade operacional da V4, com a eficiência adotada de $45 \%$.

\begin{tabular}{lrrrrrrr} 
Ano (t) & \multicolumn{1}{c}{1} & \multicolumn{1}{c}{2} & \multicolumn{1}{c}{3} & \multicolumn{1}{c}{4} & \multicolumn{1}{c}{5} & \multicolumn{1}{c}{6} & \multicolumn{1}{c}{ Total } \\
\hline Valor residual & 259250,00 & 213500,00 & 167750,00 & 122000,00 & 76250,00 & 30500,00 & \multicolumn{1}{c}{-} \\
Depreciação & 45750,00 & 45750,00 & 45750,00 & 45750,00 & 45750,00 & 45750,00 & 274500,00 \\
Juros & 36600,00 & 31110,00 & 25620,00 & 20130,00 & 14640,00 & 9150,00 & 137250,00 \\
Seguro & 3172,00 & 2696,20 & 2220,40 & 1744,60 & 1268,80 & 793,00 & 11895,00 \\
Alojamento \& Adm. & 991,25 & 991,25 & 991,25 & 991,25 & 991,25 & 991,25 & 5947,50 \\
Combustivel & 35972,32 & 35972,32 & 35972,32 & 35972,32 & 35972,32 & 35972,32 & 215833,94 \\
Óleo lubrificante & 617,40 & 617,40 & 617,40 & 617,40 & 617,40 & 617,40 & 3704,40 \\
Óleo hidráulico & 8705,57 & 8705,57 & 8705,57 & 8705,57 & 8705,57 & 8705,57 & 52233,43 \\
Comb.Ma.\& Abast. & 6048,00 & 6048,00 & 6048,00 & 6048,00 & 6048,00 & 6048,00 & 36288,00 \\
Peças Reposição & 38416,00 & 41123,00 & 36432,00 & 43826,00 & 52027,00 & 37685,00 & 249509,00 \\
Serviços mec. & 4977,00 & 4977,00 & 4977,00 & 4977,00 & 4977,00 & 4977,00 & 29862,00 \\
Sal Oper. & 6615,00 & 6615,00 & 6615,00 & 6615,00 & 6615,00 & 6615,00 & 39690,00 \\
Total Geral & & & & & & & 1056713,27 \\
\hline Valor da Colhe
\end{tabular}

Valor da colhedora nova $(V): 305.000,00$. Valor de revenda $\left(V R_{6}\right): 30.500,00$

Tabela 72. Fluxo de caixa para a colhedora em US\$, na capacidade operacional da V4, com a eficiência adotada de $55 \%$.

\begin{tabular}{lrrrrrrr} 
Ano (t) & \multicolumn{1}{c}{$\mathbf{1}$} & \multicolumn{1}{c}{$\mathbf{2}$} & \multicolumn{1}{c}{3} & \multicolumn{1}{c}{4} & \multicolumn{1}{c}{5} & \multicolumn{1}{c}{6} & \multicolumn{1}{c}{ Total } \\
\hline Valor residual & 259250,00 & 213500,00 & 167750,00 & 122000,00 & 76250,00 & 30500,00 & \multicolumn{1}{c}{--} \\
Deprecią̧ăo & 45750,00 & 45750,00 & 45750,00 & 45750,00 & 45750,00 & 45750,00 & 274500,00 \\
Juros & 36600,00 & 31110,00 & 25620,00 & 20130,00 & 14640,00 & 9150,00 & 137250,00 \\
Seguro & 3172,00 & 2696,20 & 2220,40 & 1744,60 & 1268,80 & 793,00 & 11895,00 \\
Alojamento \& Adm. & 991,25 & 991,25 & 991,25 & 991,25 & 991,25 & 991,25 & 5947,50 \\
Combustivel & 43966,17 & 43966,17 & 43966,17 & 43966,17 & 43966,17 & 43966,17 & 263797,03 \\
Óleo lubrificante & 617,40 & 617,40 & 617,40 & 617,40 & 617,40 & 617,40 & 3704,40 \\
Óleo hidráulico & 10639,65 & 10639,65 & 10639,65 & 10639,65 & 10639,65 & 10639,65 & 63837,93 \\
Comb.Ma.\& Abast. & 6048,00 & 6048,00 & 6048,00 & 6048,00 & 6048,00 & 6048,00 & 36288,00 \\
Peças Reposição & 38416,00 & 41123,00 & 36432,00 & 43826,00 & 52027,00 & 37685,00 & 249509,00 \\
Serviços mec. & 4977,00 & 4977,00 & 4977,00 & 4977,00 & 4977,00 & 4977,00 & 29862,00 \\
Sal Oper. & 6615,00 & 6615,00 & 6615,00 & 6615,00 & 6615,00 & 6615,00 & 39690,00 \\
Total Geral & & & & & & & 1116280,86 \\
\hline Valor da Colh
\end{tabular}

Valor da colhedora nova $(V): 305.000,00$. Valor de revenda $\left(V R_{6}\right): 30.500,00$ 
Tabela 73. Fluxo de caixa para a colhedora em US\$, na capacidade operacional da V4, com a eficiência adotada de $65 \%$.

\begin{tabular}{lrrrrrrr} 
Ano $(t)$ & \multicolumn{1}{c}{1} & \multicolumn{1}{c}{2} & \multicolumn{1}{c}{3} & \multicolumn{1}{c}{4} & \multicolumn{1}{c}{5} & \multicolumn{1}{c}{6} & \multicolumn{1}{c}{ Total } \\
\hline Valor residual & 259250,00 & 213500,00 & 167750,00 & 122000,00 & 76250,00 & 30500,00 & \multicolumn{1}{c}{-} \\
Depreciação & 45750,00 & 45750,00 & 45750,00 & 45750,00 & 45750,00 & 45750,00 & 274500,00 \\
Juros & 36600,00 & 31110,00 & 25620,00 & 20130,00 & 14640,00 & 9150,00 & 137250,00 \\
Seguro & 3172,00 & 2696,20 & 2220,40 & 1744,60 & 1268,80 & 793,00 & 11895,00 \\
Alojamento \& Adm. & 991,25 & 991,25 & 991,25 & 991,25 & 991,25 & 991,25 & 5947,50 \\
Combustivel & 51960,02 & 51960,02 & 51960,02 & 51960,02 & 51960,02 & 51960,02 & 311760,13 \\
Óleo lubrificante & 617,40 & 617,40 & 617,40 & 617,40 & 617,40 & 617,40 & 3704,40 \\
Óleo hidráulico & 12573,74 & 12573,74 & 12573,74 & 12573,74 & 12573,74 & 12573,74 & 75442,42 \\
Comb.Ma.\& Abast. & 6048,00 & 6048,00 & 6048,00 & 6048,00 & 6048,00 & 6048,00 & 36288,00 \\
Peças Reposição & 38416,00 & 41123,00 & 36432,00 & 43826,00 & 52027,00 & 37685,00 & 249509,00 \\
Serviços mec. & 4977,00 & 4977,00 & 4977,00 & 4977,00 & 4977,00 & 4977,00 & 29862,00 \\
Sal Oper. & 6615,00 & 6615,00 & 6615,00 & 6615,00 & 6615,00 & 6615,00 & 39690,00 \\
Total Geral & & & & & & & 1175848,45 \\
\hline Valor da Coln
\end{tabular}

Valor da colhedora nova (VI): $305.000,00$. Valor de revenda $\left(V R_{6}\right): 30.500,00$

Tabela 74. Fluxo de caixa para a colhedora em US\$, na capacidade operacional da V4, com a eficiência adotada de $75 \%$.

\begin{tabular}{|c|c|c|c|c|c|c|c|}
\hline Ano $(t)$ & 1 & 2 & 3 & 4 & 5 & 6 & Total \\
\hline Valor residual & 259250,00 & 213500,00 & 167750,00 & 122000,00 & 76250,00 & 30500,00 & $-\cdots$ \\
\hline Depreciaçāo & 45750,00 & 45750,00 & 45750,00 & 45750,00 & 45750,00 & 45750,00 & 274500,00 \\
\hline Juros & 36600,00 & 31110,00 & 25620,00 & 20130,00 & 14640,00 & 9150,00 & 137250,00 \\
\hline Seguro & 3172,00 & 2696,20 & 2220,40 & 1744,60 & 1268,80 & 793,00 & 11895,00 \\
\hline Alojamento \& Adm. & 991,25 & 991,25 & 991,25 & 991,25 & 991,25 & 991,25 & 5947,50 \\
\hline Combustivel & 59953,87 & 59953,87 & 59953,87 & 59953,87 & 59953,87 & 59953,87 & 359723,23 \\
\hline Óleo lubrificante & 617,40 & 617,40 & 617,40 & 617,40 & 617,40 & 617,40 & 3704,40 \\
\hline Óleo hidráulico & 14509,29 & 14509,29 & 14509,29 & 14509,29 & 14509,29 & 14509,29 & 87055,72 \\
\hline Comb.Ma \& Abast. & 6048,00 & 6048,00 & 6048,00 & 6048,00 & 6048,00 & 6048,00 & 36288,00 \\
\hline Peças Reposição & 38416,00 & 41123,00 & 36432,00 & 43826,00 & 52027,00 & 37685,00 & 249509,00 \\
\hline Serviços mec. & 4977,00 & 4977,00 & 4977,00 & 4977,00 & 4977,00 & 4977,00 & 29862,00 \\
\hline Sal Oper. & 6615,00 & 6615,00 & 6615,00 & 6615,00 & 6615,00 & 6615,00 & 39690,00 \\
\hline Total Geral & & & & & & & 1235424,84 \\
\hline
\end{tabular}

Valor da colhedora nova (VI): $305.000,00$. Valor de revenda $\left(V R_{6}\right): 30.500,00$ 
Tabela 75. Custo de colheita para a colhedora em US\$, nas 16 capacidades operacionais adotadas, considerando 18.900 horas em 6 anos de vida útil.

\begin{tabular}{ccccc}
\hline $\begin{array}{c}\text { Velocidade } \\
\left(\mathrm{km} \cdot \mathrm{h}^{-1}\right)\end{array}$ & $\begin{array}{c}\text { Eficiencia } \\
(\%)\end{array}$ & $\begin{array}{c}\text { Custo hora } \\
\text { US } \$ \mathrm{~h}^{-1}\end{array}$ & $\begin{array}{c}\text { Cap. Operacional } \\
\text { t. } \mathrm{h}^{-1}\end{array}$ & $\begin{array}{c}\text { Custo tonelada } \\
\text { US } \$ \mathrm{t}^{-1}\end{array}$ \\
\hline \multirow{4}{*}{ V1 } & 45 & 52,62 & 13,79 & 3,82 \\
& 55 & 55,04 & 16,85 & 3,27 \\
& 65 & 57,46 & 19,92 & 2,88 \\
& 75 & 59,88 & 22,98 & 2,61 \\
\hline \multirow{4}{*}{ V2 } & 45 & 53,00 & 24,44 & 2,17 \\
& 55 & 55,50 & 29,87 & 1,86 \\
& 65 & 58,01 & 35,3 & 1,64 \\
& 75 & 60,51 & 40,73 & 1,49 \\
\hline \multirow{4}{*}{ V3 } & 45 & 54,81 & 45,94 & 1,19 \\
& 55 & 57,71 & 56,14 & 1,03 \\
& 65 & 60,62 & 66,35 & 0,91 \\
& 75 & 63,53 & 76,56 & 0,83 \\
\hline \multirow{2}{*}{ V4 } & 45 & 55,91 & 59,37 & 0,94 \\
& 55 & 59,06 & 72,56 & 0,81 \\
& 65 & 62,21 & 85,75 & 0,73 \\
\hline
\end{tabular}

Quadro 8. Porte do canavial em números de colmo/m linear.

\begin{tabular}{lcccccccccccc}
\hline Repetição & R1 & R2 & R3 & R4 & R5 & R6 & R7 & R8 & R9 & R10 & R11 & R12 \\
\hline Ereto & 13 & 18 & 16 & 13 & 16 & 15 & 17 & 9 & 14 & 12 & 16 & 14 \\
Acamado & 2 & 1 & 2 & 0 & 3 & 0 & 3 & 1 & 11 & 0 & 0 & 1 \\
Deitado & 2 & 1 & 0 & 0 & 3 & 0 & 1 & 0 & 1 & 1 & 0 & 0 \\
\hline
\end{tabular}

Quadro 9. Peso da parte aérea em kg.

\begin{tabular}{|c|c|c|c|c|c|c|c|c|c|c|c|c|}
\hline Repetição & R1 & R2 & R3 & R4 & R5 & R6 & R7 & $R 8$ & $\mathrm{R9}$ & R10 & R11 & R12 \\
\hline Ponteiros & 2,74 & 2,45 & 2,35 & 1,52 & 2,13 & 2,6 & 3 & 3,41 & 3,51 & 1,59 & 2,57 & 5,07 \\
\hline Folhas verdes & 6,23 & 5,96 & 6,33 & 3,25 & 4,61 & 8,5 & 6,17 & 6,6 & $6,6 s$ & 3,89 & 4,92 & 7,82 \\
\hline Palhas & 3,85 & 95 & 4,81 & 2,39 & 3,65 & 5,72 & 4,36 & 5,28 & 6,06 & 3,09 & 3,72 & 5,72 \\
\hline Colmos & 63,44 & 60,91 & 71,1 & 30,37 & 50,5 & 87,37 & 64,5 & 63 & 61,5 & 40,6 & 55,04 & 83,87 \\
\hline
\end{tabular}

\begin{tabular}{lllllllllllll} 
No. de colmos. $\mathrm{m}^{-1}$ & 17 & 20 & 18 & 13 & 22 & 15 & 21 & 10 & 26 & 13 & 16 & 15 \\
\hline
\end{tabular}


Quadro 10. Comprimento dos colmos em $\mathrm{m}$.

\begin{tabular}{ccccccccccccc}
\hline Repetição & R1 & R2 & R3 & R4 & R5 & R6 & R7 & R8 & R9 & R10 & R11 & R12 \\
\hline 1 & 3,42 & 2,9 & 3,8 & 2,9 & 2,33 & 3,4 & 3,4 & 3,36 & 3,61 & 2,93 & 3,13 & 3,7 \\
2 & 3,08 & 3 & 3,65 & 2,84 & 3,25 & 3,8 & 3,8 & 3,58 & 3,02 & 2,77 & 3 & 3,93 \\
3 & 2,95 & 3,2 & 3,42 & 3,12 & 2,71 & 2,48 & 2,48 & 3,6 & 3,2 & 3,85 & 3,65 & 3,28 \\
4 & 3,32 & 2,65 & 3,58 & 2,55 & 3,37 & 3,1 & 3,1 & 3,58 & 3,15 & 3,3 & 3,12 & 3,74 \\
5 & 2,69 & 3,15 & 3,39 & 3,09 & 3,12 & 3,52 & 3,52 & 3,51 & 3,1 & 3,44 & 3,5 & 3,75 \\
6 & 2,05 & 3,2 & 3,76 & 3,31 & 3,47 & 3,49 & 3,49 & 3,54 & 3,24 & 3,53 & 3,34 & 3,85 \\
7 & 3,13 & 3,22 & 3,89 & 2,82 & 3,15 & 3,34 & 3,34 & 2,62 & 3,59 & 3,91 & 3,78 & 4,03 \\
8 & 3,14 & 3,38 & 3,4 & 2,71 & 2,7 & 3,22 & 3,22 & 3,72 & 3,06 & 3,57 & 3,84 & 3,81 \\
9 & 2,05 & 3,65 & 3,59 & 2,86 & 3,34 & 3,78 & 3,78 & 2,73 & 3,39 & 3,35 & 3,9 & 3,45 \\
10 & 2,88 & 3,26 & 3,71 & 3,3 & 3,06 & 2,88 & 2,88 & 3,03 & 3,62 & 3,83 & 3,64 & 3,42 \\
\hline
\end{tabular}

Quadro 11. Tamanho e cisalhamento dos rebolos na velocidade V1.

\begin{tabular}{|c|c|c|c|c|c|c|c|c|c|c|c|}
\hline R1 & $\begin{array}{c}\text { Tamanho } \\
\text { Rebolos }(\mathrm{cm})\end{array}$ & $P / M^{\#}$ & R2 & $\begin{array}{c}\text { Tamanho } \\
\text { Rebolos }(\mathrm{cm})\end{array}$ & $\mathrm{P} / \mathrm{M}^{*}$ & R3 & $\begin{array}{c}\text { Tamanho } \\
\text { Rebolos }(\mathrm{cm})\end{array}$ & $\mathrm{P} / \mathrm{M}^{\#}$ & R4 & $\begin{array}{c}\text { Tamanho } \\
\text { Rebolos }(\mathrm{cm})\end{array}$ & $\mathrm{P} / \mathrm{M}^{\#}$ \\
\hline 1 & 26 & 0 & 1 & 21 & 0 & 1 & 21 & 0 & 1 & 25 & 0 \\
\hline 2 & 23 & 0 & 2 & 22 & 0 & 2 & 19 & 0 & 2 & 24 & 0 \\
\hline 3 & 22 & 1 & 3 & 12 & 0 & 3 & 24 & 0 & 3 & 20 & 0 \\
\hline 4 & 22 & 0 & 4 & 26 & 1 & 4 & 28 & 0 & 4 & 23 & 0 \\
\hline 5 & 21 & 0 & 5 & 26 & 0 & 5 & 23 & 0 & 5 & 22 & 0 \\
\hline 6 & 23 & 0 & 6 & 21 & 0 & 6 & 20 & 0 & 6 & 21 & 0 \\
\hline 7 & 21 & 0 & 7 & 20 & 0 & 7 & 21 & 0 & 7 & 20 & 0 \\
\hline 8 & 35 & 1 & 8 & 21 & 0 & 8 & 27 & 0 & 8 & 20 & 0 \\
\hline 9 & 21 & 0 & 9 & 23 & 0 & 9 & 28 & 0 & 9 & 21 & 0 \\
\hline 10 & 21 & 1 & 10 & 21 & 0 & 10 & 22 & 0 & 10 & 19 & 0 \\
\hline 11 & 20 & 0 & 11 & 21 & 0 & 11 & 19 & 0 & 11 & 20 & 0 \\
\hline 12 & 22 & 0 & 12 & 22 & 0 & 12 & 22 & 0 & 12 & 21 & 0 \\
\hline 13 & 21 & 0 & 13 & 20 & 0 & 13 & 20 & 0 & 13 & 25 & 0 \\
\hline 14 & 21 & 0 & 14 & 22 & 0 & 14 & 21 & 0 & 14 & 21 & 0 \\
\hline 15 & 28 & 0 & 15 & 23 & 0 & 15 & 20 & 0 & 15 & 19 & 1 \\
\hline 16 & 20 & 0 & 16 & 25 & 0 & 16 & 23 & 0 & 16 & 23 & 0 \\
\hline 17 & 20 & 0 & 17 & 22 & 0 & 17 & 19 & 1 & 17 & 26 & 0 \\
\hline 18 & 23 & 1 & 18 & 24 & 0 & 18 & 17 & 0 & 18 & 20 & 0 \\
\hline 19 & 27 & 0 & 19 & 23 & 0 & 19 & 22 & 0 & 19 & 22 & 0 \\
\hline$\frac{20}{\pi}$ & 18 & 0 & 20 & 16 & 0 & 20 & 17 & 0 & 20 & 20 & 0 \\
\hline
\end{tabular}

\#P/M = Rebolos perfeitos (0), macerados de 1 ou 2 lados. 
Quadro 12. Tamanho e cisalhamento dos rebolos na velocidade V2.

\begin{tabular}{|c|c|c|c|c|c|c|c|c|c|c|c|}
\hline $\begin{array}{l}\mathrm{R} 1 \\
\mathrm{~F}\end{array}$ & $\begin{array}{l}\text { Tamanho } \\
\text { Rebolos }(\mathrm{cm})\end{array}$ & $\mathrm{P} / \mathrm{M}^{*}$ & & $\begin{array}{c}\text { Tamanho } \\
\text { Rebolos }(\mathrm{cm})\end{array}$ & $\mathrm{P} / \mathrm{M}^{\#}$ & R3 & $\begin{array}{c}\text { Tamanho } \\
\text { Rebolos }(\mathrm{cm})\end{array}$ & $\mathrm{P} / \mathrm{M}^{*}$ & $\mathrm{R} 4$ & $\begin{array}{l}\text { Tamanho } \\
\text { Rebolos }(\mathrm{cm})\end{array}$ & $\mathrm{P} / \mathrm{M}^{7}$ \\
\hline 1 & 20 & 0 & 1 & 19,5 & 0 & 1 & 22 & 1 & 1 & 17 & 0 \\
\hline 2 & 23 & 0 & 2 & 19 & 0 & 2 & 21,5 & 0 & 2 & 22 & 0 \\
\hline 3 & 25 & 0 & 3 & 27 & 0 & 3 & 21 & 2 & 3 & 20,5 & 0 \\
\hline 4 & 27 & 1 & 4 & 23 & 1 & 4 & 20 & 0 & 4 & 20,5 & 0 \\
\hline 5 & 18 & 0 & 5 & 19 & 0 & 5 & 21 & 0 & 5 & 20 & 0 \\
\hline 6 & 17 & 0 & 6 & 21,5 & 0 & 6 & 19 & 0 & 6 & 17 & 0 \\
\hline 7 & 20 & 0 & 7 & 16 & 1 & 7 & 19 & 0 & 7 & 18 & 0 \\
\hline 8 & 22 & 0 & 8 & 24 & 0 & 8 & 27 & 0 & 8 & 20,5 & 2 \\
\hline 9 & 22 & 0 & 9 & 20,5 & 1 & 9 & 23 & 0 & 9 & 21,5 & 0 \\
\hline 10 & 21 & 0 & 10 & 20,5 & 1 & 10 & 23 & 0 & 10 & 22 & 0 \\
\hline 11 & 20 & 0 & 11 & 19,5 & 0 & 11 & 19,5 & 1 & 11 & 21,5 & 0 \\
\hline 12 & 19 & 0 & 12 & 19 & 0 & 12 & 19 & 1 & 12 & 18 & 0 \\
\hline 13 & 16 & 0 & 13 & 24 & 0 & 13 & 22 & 0 & 13 & 18,5 & 0 \\
\hline 14 & 24 & 0 & 14 & 16 & 1 & 14 & 24 & 0 & 14 & 21 & 0 \\
\hline 15 & 24 & 0 & 15 & 23 & 0 & 15 & 25 & 0 & 15 & 17,5 & 0 \\
\hline 16 & 21 & 0 & 16 & 21 & 0 & 16 & 20 & 0 & 16 & 20 & 0 \\
\hline 17 & 21 & 0 & 17 & 28 & 1 & 17 & 21 & 1 & 17 & 21,5 & 1 \\
\hline 18 & 22 & 0 & 18 & 27 & 0 & 18 & 17,5 & 1 & 18 & 19,5 & 0 \\
\hline 19 & 23 & 0 & 19 & 26,5 & 0 & 19 & 22 & 1 & 19 & 19,5 & 1 \\
\hline 20 & 19 & 0 & 20 & 25 & 2 & 20 & 17 & 1 & 20 & 18 & 0 \\
\hline
\end{tabular}

"P/M = Rebolos perfeitos (0), macerados de 1 ou 2 lados.

Quadro 13. Tamanho e cisalhamento dos rebolos na velocidade V3.

\begin{tabular}{|c|c|c|c|c|c|c|c|c|c|c|c|}
\hline R1 & $\begin{array}{c}\text { Tamanho } \\
\text { Rebolos (cm) }\end{array}$ & $\mathrm{P} / \mathrm{M}^{\#}$ & $\mathrm{R} 2$ & $\begin{array}{c}\text { Tamanho } \\
\text { Rebolos }(\mathrm{cm})\end{array}$ & $\mathrm{P} / \mathrm{M}^{\#}$ & R3 & $\begin{array}{c}\text { Tamanho } \\
\text { Rebolos }(\mathrm{cm})\end{array}$ & $\mathrm{P} / \mathrm{M}^{\#}$ & R4 & $\begin{array}{c}\text { Tamanho } \\
\text { Rebolos }(\mathrm{cm})\end{array}$ & $\mathrm{P} / \mathrm{M}^{\#}$ \\
\hline 1 & 19,5 & 0 & 1 & 21 & 1 & 1 & 21 & 0 & 1 & 21 & 0 \\
\hline 2 & 16 & 1 & 2 & 21 & 0 & 2 & 20 & 0 & 2 & 20,5 & 0 \\
\hline 3 & 18 & 0 & 3 & 22 & 0 & 3 & 19 & 0 & 3 & 22 & 0 \\
\hline 4 & 15 & 1 & 4 & 22 & 0 & 4 & 22 & 1 & 4 & 22,5 & 0 \\
\hline 5 & 26 & 1 & 5 & 19 & 0 & 5 & 20 & 1 & 5 & 20 & 0 \\
\hline 6 & 22 & 0 & 6 & 20 & 0 & 6 & 23 & 1 & 6 & 22 & 2 \\
\hline 7 & 20,5 & 0 & 7 & 21 & 0 & 7 & 20,5 & 0 & 7 & 19,5 & 0 \\
\hline 8 & 20 & 0 & 8 & 18 & 1 & 8 & 21 & 0 & 8 & 18 & 0 \\
\hline 9 & 22 & 0 & 9 & 26 & 0 & 9 & 21,5 & 0 & 9 & 21,5 & 0 \\
\hline 10 & 19,5 & 0 & 10 & 21 & 0 & 10 & 20,5 & 1 & 10 & 21,5 & 0 \\
\hline 11 & 21 & 0 & 11 & 16 & 0 & 11 & 19 & 1 & 11 & 19 & 0 \\
\hline 12 & 23,5 & 0 & 12 & 20 & 0 & 12 & 20 & 0 & 12 & 19,5 & 0 \\
\hline 13 & 22 & 0 & 13 & 22 & 0 & 13 & 20,5 & 0 & 13 & 20 & 0 \\
\hline 14 & 20,5 & 1 & 14 & 21 & 0 & 14 & 22 & 2 & 14 & 22,5 & 0 \\
\hline 15 & 23 & 0 & 15 & 20 & 0 & 15 & 20 & 0 & 15 & 21,5 & 1 \\
\hline 16 & 17,5 & 0 & 16 & 19 & 0 & 16 & 24 & 1 & 16 & 20 & 0 \\
\hline 17 & 25,5 & 1 & 17 & 20 & 0 & 17 & 17 & 0 & 17 & 22 & 0 \\
\hline 18 & 23 & 0 & 18 & 21 & 0 & 18 & 23 & 1 & 18 & 18,5 & 0 \\
\hline 19 & 23 & 1 & 19 & 23 & 0 & 19 & 20 & 0 & 19 & 18 & 0 \\
\hline 20 & 20,5 & 0 & 20 & 21 & 1 & 20 & 21 & 0 & 20 & 23 & 0 \\
\hline
\end{tabular}

${ }^{\text {"P }} \mathrm{P}$ M $=$ Rebolos perfeitos $(0)$, macerados de 1 ou 2 lados. 
Quadro 14. Tamanho e cisalhamento dos rebolos na velocidade $V 4$.

\begin{tabular}{|c|c|c|c|c|c|c|c|c|c|c|c|}
\hline${ }^{21}{ }_{F}$ & $\begin{array}{l}\text { Tamanho } \\
\text { Rebolos }(\mathrm{cm})\end{array}$ & $\mathrm{P} / \mathrm{M}^{*}$ & R2 & $\begin{array}{c}\text { Tamanho } \\
\text { Rebolos }(\mathrm{cm})\end{array}$ & $\mathrm{P} / \mathrm{M}^{\mathrm{A}}$ & R3 & $\begin{array}{l}\text { Tamanho } \\
\text { Rebolos }(\mathrm{cm})\end{array}$ & $P / M^{\#}$ & $\mathrm{R}^{2}$ & $\begin{array}{c}\text { Tamanho } \\
\text { Rebolos }(\mathrm{cm})\end{array}$ & $P / M^{7}$ \\
\hline 1 & 22 & $\overline{0}$ & 1 & 22 & 0 & 1 & 24 & 0 & 1 & 20,5 & 0 \\
\hline 2 & 27 & 1 & 2 & 22,5 & 0 & 2 & 21 & 1 & 2 & 21 & 0 \\
\hline 3 & 18,5 & 0 & 3 & 20 & 0 & 3 & 14 & 0 & 3 & 24 & 0 \\
\hline 4 & 20 & 1 & 4 & 23 & 0 & 4 & 19,5 & 0 & 4 & 21 & 0 \\
\hline 5 & 20 & 1 & 5 & 21 & 0 & 5 & 20,5 & 0 & 5 & 24,5 & 0 \\
\hline 6 & 23 & 0 & 6 & 21,5 & 0 & 6 & 21 & 0 & 6 & 20,5 & 0 \\
\hline 7 & 20,5 & 1 & 7 & 20,5 & 0 & 7 & 27 & 0 & 7 & 21 & 0 \\
\hline 8 & 19,5 & 0 & 8 & 24 & 0 & 8 & 21,5 & 1 & 8 & 22 & 1 \\
\hline 9 & 20 & 0 & 9 & 21 & 0 & 9 & 23 & 0 & 9 & 20 & 0 \\
\hline 10 & 23 & 2 & 10 & 20 & 1 & 10 & 19 & 1 & 10 & 2 & 0 \\
\hline 11 & 27 & 0 & 11 & 16,5 & 0 & 11 & 21 & 1 & 11 & 13 & 1 \\
\hline 12 & 20 & 0 & 12 & 23 & 2 & 12 & 20 & 1 & 12 & 23,5 & 0 \\
\hline 13 & 20 & 0 & 13 & 21 & 0 & 13 & 20,5 & 0 & 13 & 22 & 0 \\
\hline 14 & 23 & 0 & 14 & 20 & 0 & 14 & 21,5 & 0 & 14 & 20 & 1 \\
\hline 15 & 22 & 2 & 15 & 26 & 1 & 15 & 23 & 0 & 15 & 18 & 0 \\
\hline 16 & 18 & 1 & 16 & 21 & 0 & 16 & 24 & 0 & 16 & 21,5 & 0 \\
\hline 17 & 11,5 & 2 & 17 & 17 & 1 & 17 & 20 & 0 & 17 & 20 & 0 \\
\hline 18 & 21 & 0 & 18 & 20 & 0 & 18 & 23 & 0 & 18 & 21 & 0 \\
\hline 19 & 18 & 0 & 19 & 22 & 1 & 19 & 21,5 & 0 & 19 & 28,5 & 0 \\
\hline 20 & 18 & 1 & 20 & 20 & 0 & 20 & 20 & 0 & 20 & 19,8 & 0 \\
\hline
\end{tabular}

"P/M = Rebolos perfeitos (0), macerados de 1 ou 2 lados.

Quadro 15. Valores de desempenho Operacional

\begin{tabular}{|c|c|c|c|c|c|c|c|}
\hline \multirow{2}{*}{ Trat. } & \multirow{2}{*}{ Rep. } & \multirow{2}{*}{\multicolumn{2}{|c|}{$\begin{array}{l}\text { Vel.Méd. Cap.Efet.brut. } \\
\mathrm{Km} \cdot \mathrm{h}^{-1} \quad \mathrm{t}^{-1}\end{array}$}} & \multirow{2}{*}{$\begin{array}{c}\text { Efc.Manip. } \\
\%\end{array}$} & \multirow{2}{*}{$\begin{array}{c}\text { Cap. Ef. Liq. } \\
\text { t. }^{-1}\end{array}$} & \multirow{2}{*}{\multicolumn{2}{|c|}{$\begin{array}{l}\text { Cons.Comb. } \\
\left(1 . \mathrm{h}^{-1}\right) \quad\left(1 . \mathrm{t}^{-1}\right)\end{array}$}} \\
\hline & & & & & & & \\
\hline \multirow[t]{4}{*}{$T-V 1$} & $\mathrm{R} 1$ & 1,70 & 27,41 & 0,84 & 23,04 & 99,90 & 3,64 \\
\hline & R2 & 1,71 & 33,82 & 0,84 & 28,38 & 98,00 & 2,90 \\
\hline & R3 & 1,67 & 27,77 & 0,88 & 24,55 & 96,50 & 3,48 \\
\hline & R4 & 1,72 & 33,56 & 0,87 & 29,21 & 95,00 & 2,83 \\
\hline \multirow[t]{4}{*}{ T-V2 } & R1 & 3,40 & 53,66 & 0,91 & 49,03 & 95,40 & 1,78 \\
\hline & R2 & 3,30 & 52,98 & 0,90 & 47,52 & 97,30 & 1,84 \\
\hline & R3 & 3,33 & 55,93 & 0,92 & 51,43 & 96,10 & 1,72 \\
\hline & R4 & 3,46 & 54,67 & 0,92 & 50,47 & 96,10 & 1,76 \\
\hline \multirow{4}{*}{$T-V 3$} & R1 & 5,45 & 110,87 & 0,94 & 103,85 & 105,20 & 0,95 \\
\hline & R2 & 5,37 & 106,12 & 0,96 & 101,55 & 105,20 & 0,99 \\
\hline & R3 & 5,54 & 77,61 & 0,92 & 71,15 & 102,20 & 1,32 \\
\hline & R4 & 5,22 & 113,72 & 0,89 & 101,50 & 103,00 & 0,91 \\
\hline \multirow[t]{4}{*}{$T-V 4$} & $\mathrm{R} 1$ & 7,83 & 110,24 & 0,96 & 105,41 & 108,60 & 0,99 \\
\hline & R2 & 7,83 & 132,39 & 0,94 & 125,01 & 109,00 & 0,82 \\
\hline & R3 & 7,83 & 147,16 & 0,95 & 140,17 & 107,90 & 0,73 \\
\hline & $\mathrm{R} 4$ & 8,57 & 137,94 & 0,92 & 127,59 & 108,30 & 0,79 \\
\hline
\end{tabular}


Quadro 16. Valores de perdas no campo, em tha.

\begin{tabular}{|c|c|c|c|c|c|c|c|c|c|}
\hline Trat. F & & $\begin{array}{l}\text { Colmos } \\
\text { e/ou } \\
\text { Frações } \\
\text { (t.ha }^{-1} \text { ) }\end{array}$ & $\begin{array}{l}\text { Rebolos } \\
\text { Inteiros } \\
\left(\text { t.ha }^{-1}\right)\end{array}$ & $\begin{array}{l}\text { Frações } \\
\text { de } \\
\text { Rebolos } \\
\left(\text { t.ha }^{-1}\right)\end{array}$ & $\begin{array}{c}\text { Raízes } \\
\text { no } \\
\text { Campo } \\
\left(\text { t.ha }^{-1}\right)\end{array}$ & $\begin{array}{l}\text { Rebolos } \\
\text { na } \\
\text { Soqueira } \\
\left(t^{\prime} . \mathrm{ha}^{-1}\right)\end{array}$ & $\begin{array}{c}\text { Perda } \\
\text { Total } \\
\text { Máquina } \\
\left(\text { t.ha }^{-1}\right)\end{array}$ & $\begin{array}{l}\text { Produtividade } \\
\text { Agrícola } \\
\text { Canavial } \\
\text { (t.ha }^{-1} \text { ) }\end{array}$ & $\begin{array}{l}\text { Perda } \\
\text { Total } \\
\text { Agrícola } \\
(\%)\end{array}$ \\
\hline \multirow[t]{4}{*}{$T-V 1$} & R1 & 3,39 & 3,75 & 11,34 & 0,10 & 1,48 & 20,06 & 125,29 & 16,01 \\
\hline & R2 & 2,25 & 4,63 & 17,76 & 0,05 & 0,69 & 25,38 & 157,66 & 16,10 \\
\hline & R3 & 0,00 & 2,68 & 11,75 & 0,08 & 0,14 & 14,65 & 125,87 & 11,64 \\
\hline & R4 & 0,00 & 2,96 & 11,93 & 0,00 & 3,01 & 17,91 & 138,22 & 12,96 \\
\hline \multirow[t]{4}{*}{ T-V2 } & $\mathrm{R} 1$ & 0,00 & 2,26 & 6,52 & 0,00 & 1,29 & 10,07 & 116,74 & 8,63 \\
\hline & R2 & 0,00 & 2,79 & 8,21 & 0,06 & 1,24 & 12,29 & 118,70 & 10,35 \\
\hline & R3 & 0,00 & 2,24 & 6,24 & 0,00 & 1,18 & 9,66 & 19 & 8,03 \\
\hline & R4 & 0 , & 06 & 3 & 00 & & 3 & 67 & 68 \\
\hline \multirow[t]{4}{*}{$T-V 3$} & R1 & 0,00 & 2,63 & 6,26 & 0,14 & 0,40 & 9,44 & 46,89 & 6,43 \\
\hline & R2 & 0,00 & 1,35 & 4,52 & 0,04 & 0,00 & 5,91 & 36,30 & 4,33 \\
\hline & R3 & 0,00 & 1,38 & 4,76 & 0,00 & 2,69 & 8,84 & 106,10 & 8,33 \\
\hline & R4 & 0,00 & 4,45 & 8,39 & 0,00 & 4,95 & 17,80 & 165,62 & 10,75 \\
\hline \multirow[t]{4}{*}{$T-V 4$} & R1 & 0,00 & 2,99 & 6,49 & 0,00 & 1,43 & 10,91 & 104,67 & 10,42 \\
\hline & R2 & 3,10 & 1,88 & 10,14 & 0,00 & 1,92 & 17,03 & 128,47 & 13,26 \\
\hline & R3 & 0,00 & 3,13 & 7,73 & 0,00 & 4,36 & 15,21 & 134,55 & 11,31 \\
\hline & R4 & 0,00 & 9,00 & 8,50 & 0,00 & 6,10 & 23,60 & 132,09 & 17,86 \\
\hline
\end{tabular}

Quadro 17. Valores de perdas no campo, em \%.

\begin{tabular}{|c|c|c|c|c|c|c|c|}
\hline Trat. & Rep. & $\begin{array}{l}\text { Colmos } \\
\text { e/ou } \\
\text { Frações } \\
(\%)\end{array}$ & $\begin{array}{l}\text { Rebolos } \\
\text { Inteiros }\end{array}$ & $\begin{array}{l}\text { Frações } \\
\text { de } \\
\text { Rebolos } \\
(\%) \\
\end{array}$ & $\begin{array}{c}\text { Raizes } \\
\text { no } \\
\text { Campo } \\
(\%) \\
\end{array}$ & $\begin{array}{c}\text { Rebolos } \\
\text { na } \\
\text { Soqueira } \\
(\%)\end{array}$ & $\begin{array}{l}\text { Perda } \\
\text { Total } \\
\text { Máquina } \\
(\%)\end{array}$ \\
\hline \multirow[t]{4}{*}{$\mathrm{T} 2 \mathrm{~V} 1$} & R1 & 16,92 & 18,70 & 56,55 & 0,47 & 7,36 & 100,00 \\
\hline & R2 & &, 25 & ,98 & 0 & 2 & \\
\hline & R3 & 0,00 & 18,28 & 0,18 & 57 & $y$ & 0,00 \\
\hline & R4 & 0,00 &, 55 & 66,63 & 0 & 32 & 100,00 \\
\hline \multirow[t]{4}{*}{$\mathrm{T} 2 \mathrm{~V} 2$} & R1 & 0,00 & 2,46 &, 18 & 00 & 1 & 0 \\
\hline & R2 & 0,00 & 2,6 & 6,78 & ,48 & 10,07 & 00 \\
\hline & R3 & & 18 &, 62 & 00 & & \\
\hline & R4 & & & & & & \\
\hline \multirow[t]{4}{*}{$\mathrm{T} 2 \mathrm{~V} 3$} & R1 & & & & & & \\
\hline & R & & & & & & \\
\hline & R3 & & & & & & 0,00 \\
\hline & R4 & & 5,02 & 16 & 0 & 3 & 0,00 \\
\hline \multirow[t]{4}{*}{ T2V4 } & R1 & 0,00 & 3 & 3,5 & 0,00 & 10 & 100,00 \\
\hline & R2 & 18,1 & 11,04 & 59,54 & ,00 & 11,25 & 100,00 \\
\hline & R3 & 0, & 20,58 & 50,78 & 00 & 8.64 & 100,00 \\
\hline & R4 & 0 & 3,1 & 6,03 & $0,0 \mathrm{C}$ & 25,83 & 100,0 \\
\hline
\end{tabular}


Quadro 18. Valores de perdas no campo, em kgf.

\begin{tabular}{|c|c|c|c|c|c|c|c|}
\hline Trat. & Rep. & $\begin{array}{l}\text { Colmos } \\
\text { e/ou } \\
\text { Fraçōes } \\
\text { (kgf) }\end{array}$ & $\begin{array}{c}\text { Rebolos } \\
\text { Inteiros } \\
\text { (kgf) }\end{array}$ & $\begin{array}{l}\text { Frações } \\
\text { de } \\
\text { Rebolos } \\
\text { (kgf) }\end{array}$ & $\begin{array}{l}\text { Raizes } \\
\text { no } \\
\text { Campo } \\
\text { (kgf) }\end{array}$ & $\begin{array}{c}\text { Rebolos } \\
\text { na } \\
\text { Soqueira } \\
\text { (kgf) }\end{array}$ & $\begin{array}{c}\text { Perda } \\
\text { Total } \\
\text { Máquina } \\
\text { (kgf) }\end{array}$ \\
\hline \multirow[t]{4}{*}{ T2V1 } & $\mathrm{R} 1$ & 1,43 & 1,58 & 4,76 & 0,04 & 0,62 & 8,42 \\
\hline & $\mathrm{R} 2$ & 0,95 & 1,95 & 7,46 & 0,02 & 0,29 & 10,66 \\
\hline & R3 & 0,00 & 1,13 & 4,93 & 0,04 & 0,06 & 6,15 \\
\hline & $\mathrm{R} 4$ & 0,00 & 1,25 & 5,01 & 0,00 & 1,27 & 7,52 \\
\hline \multirow[t]{4}{*}{ T2V2 } & $\mathrm{R} 1$ & 0,00 & 0,95 & 2,74 & 0,00 & 0,54 & 4,23 \\
\hline & R2 & 0,00 & 1,17 & 3,45 & 0,03 & 0,52 & 5,16 \\
\hline & R3 & 0,00 & 0,94 & 2,62 & 0,00 & 0,5 & 4,06 \\
\hline & R4 & 0,00 & 45 & 2,66 & 00 & 0,5 & 3,67 \\
\hline \multirow[t]{4}{*}{$\mathrm{T} 2 \mathrm{~V} 3$} & R1 & 0,00 & 11 & 2,63 & 6 & 0,17 & 3,97 \\
\hline & $\mathrm{R} 2$ & 0,00 & 0,57 & 1,90 & 0,02 & 0,00 & 2,48 \\
\hline & R3 & 0,00 & 0,58 & 2,00 & 0,00 & 1,13 & 3,71 \\
\hline & R4 & 0,00 & 1,87 & 3,53 & 0,00 & 2,08 & 7,48 \\
\hline \multirow[t]{4}{*}{ T2V4 } & $\mathrm{R} 1$ & 0,00 & 1,26 & 2,73 & 0,00 & 0,60 & 4,58 \\
\hline & R2 & 1,30 & 0,79 & 4,26 & 0,00 & 0,81 & 7,15 \\
\hline & R3 & 0,00 & 1,32 & 3,25 & 0,00 & 1,83 & 0,39 \\
\hline & R4 & 0,00 & 3,78 & 3,57 & 0,00 & 2,56 & 9,91 \\
\hline
\end{tabular}

Quadro 19. Valores de cargas líquidas.

\begin{tabular}{cccccc}
\hline Trat. & Rep. & $\begin{array}{c}\text { Matéria } \\
\text { Prima Colhida } \\
\text { Kgf. }^{-1}\end{array}$ & $\begin{array}{c}\text { Total } \\
\text { Trash } \\
\%\end{array}$ & $\begin{array}{c}\text { Colmos } \\
\text { Industrializáveis } \\
\text { Kgf.m }^{-1}\end{array}$ & $\begin{array}{c}\text { Produtividade } \\
\text { Agricola } \\
\text { t.ha }^{-1}\end{array}$ \\
\hline T-V1 & R1 & 16,14 & 8,65 & 14,75 & 125,29 \\
& R2 & 19,82 & 6,53 & 18,53 & 157,66 \\
& R3 & 16,58 & 6,04 & 15,58 & 125,87 \\
& R4 & 19,48 & 13,54 & 16,84 & 138,22 \\
\hline T-V2 & R1 & 15,80 & 5,49 & 14,93 & 116,74 \\
& R2 & 16,04 & 7,07 & 14,91 & 118,70 \\
& R3 & 16,78 & 7,77 & 15,47 & 120,19 \\
& R4 & 15,79 & 6,98 & 14,69 & 113,67 \\
\hline T-V3 & R1 & 20,33 & 5,23 & 19,26 & 146,89 \\
& R2 & 19,75 & 7,54 & 18,26 & 136,30 \\
& R3 & 14,01 & 2,83 & 13,62 & 106,10 \\
& R4 & 21,80 & 5,05 & 20,70 & 165,62 \\
\hline T-V4 & R1 & 14,09 & 6,81 & 13,13 & 104,67 \\
& R2 & 16,92 & 7,78 & 15,60 & 128,47 \\
& R3 & 18,80 & 11,15 & 16,71 & 134,55 \\
& R4 & 16,09 & 5,61 & 15,19 & 132,09 \\
\hline
\end{tabular}


Quadro 20. Valores das amostras para determinação da qualidade da matéria prima colhida pela colhedora, em kgf.

\begin{tabular}{|c|c|c|c|c|c|c|c|c|c|c|}
\hline Trat. & Rep. & Ponteiros & $\begin{array}{l}\text { Folhas } \\
\text { verdes }\end{array}$ & Palha & Raízes & $\begin{array}{c}\text { Matéria } \\
\text { Estranha } \\
\text { Vegetal } \\
\text { Total }\end{array}$ & $\begin{array}{c}\text { Matéria } \\
\text { Estranha } \\
\text { Mineral } \\
\text { Total }\end{array}$ & $\begin{array}{l}\text { Matéria } \\
\text { Estranha } \\
\text { Total }\end{array}$ & Cana & $\begin{array}{c}\text { Amostra } \\
\text { Total }\end{array}$ \\
\hline & & $\mathrm{kgf}$ & $\mathrm{kgf}$ & kgf & $\mathrm{kgf}$ & $\mathrm{kgf}$ & kgf & $\mathrm{kgf}$ & $\mathrm{kgf}$ & $\mathrm{kgf}$ \\
\hline \multirow[t]{4}{*}{$T-V 1$} & R1 & 0,7 & 0,69 & 0,04 & 0 & 1,43 & 0 & 1,43 & 15,11 & 16,54 \\
\hline & R2 & 1,66 & 0,03 & 0,04 & 0 & 1,73 & 0,02 & 1,75 & 25,05 & 26,8 \\
\hline & R3 & 1,33 & 0,07 & 0,12 & 0 & 1,52 & 0 & 1,52 & 23,66 & 25,18 \\
\hline & R4 & 1,87 & 0,32 & 0,05 & 0 & 2,24 & 0,77 & 3,01 & 19,22 & 22,23 \\
\hline \multirow[t]{4}{*}{ T-V2 } & R1 & 0,63 & 0,36 & 0,02 & 0 & 1,01 & 0 & 1,01 & 17,4 & 18,41 \\
\hline & R2 & 0,99 & 0,09 & 0,03 & 0 & 1,11 & 0 & 1,11 & 14,58 & 15,69 \\
\hline & R3 & 1,49 & 0,27 & 0,07 & 0 & 1,83 & 0 & 1,83 & 21,73 & 23,56 \\
\hline & R4 & 0,79 & 0,09 & 0,03 & 0 & 0,91 & 0 & 0,91 & 12,12 & 13,03 \\
\hline \multirow[t]{4}{*}{$\mathrm{T}-\mathrm{V} 3$} & R1 & 0,7 & 0,13 & 0,07 & 0 & 0,9 & 0 & 0,9 & 16,31 & 17,21 \\
\hline & R2 & 0,46 & 0,22 & 0,17 & 0 & 0,85 & 0 & 0,85 & 10,42 & 11,27 \\
\hline & R3 & 0,4 & 0,03 & 0,04 & 0 & 0,47 & 0 & 0,47 & 16,13 & 16,6 \\
\hline & R4 & 0,77 & 0,13 & 0,02 & 0 & 0,92 & 0 & 0,92 & 17,28 & 18,2 \\
\hline \multirow[t]{4}{*}{ T-V4 } & R1 & 0,55 & 0,2 & 0,13 & 0 & 0,88 & 0 & 0,88 & 12,04 & 12,92 \\
\hline & R2 & 0,48 & 0 & 0,08 & 0,22 & 0,78 & 0 & 0,78 & 9,25 & 10,03 \\
\hline & R3 & 1,41 & 0,37 & 0,15 & 0 & 1,93 & 0 & 1,93 & 15,38 & 17,31 \\
\hline & R4 & 0,38 & 0,15 & 0,12 & 0 & 0,65 & 0 & 0,65 & 10,93 & 11,58 \\
\hline
\end{tabular}

Quadro 21. Valores das amostras para determinação da qualidade da matéria prima colhida pela colhedora, em \%.

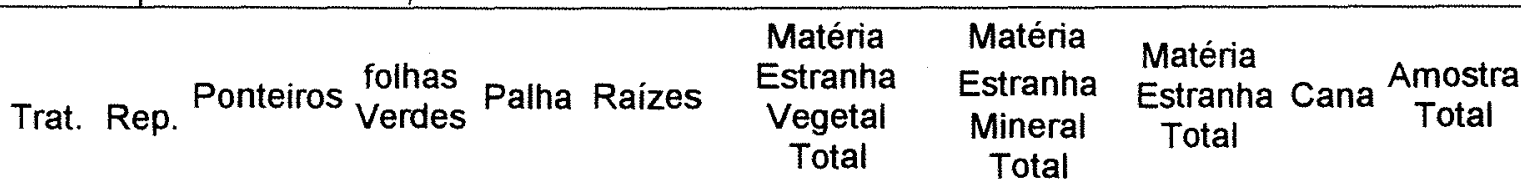

\begin{tabular}{ccccccccccc} 
& & $\%$ & $\%$ & $\%$ & $\%$ & $\%$ & $\%$ & $\%$ & $\%$ & $\%$ \\
\hline T-V1 & R1 & $\mathbf{4 , 2 3}$ & $\mathbf{4 , 1 7}$ & 0,24 & 0,00 & $\mathbf{8 , 6 5}$ & 0,00 & 8,65 & 91,35 & 100 \\
& R2 & 6,19 & 0,11 & 0,15 & 0,00 & 6,46 & 0,07 & 6,53 & 93,47 & 100 \\
& R3 & 5,28 & 0,28 & 0,48 & 0,00 & 6,04 & 0,00 & 6,04 & 93,96 & 100 \\
& R4 & $\mathbf{8 , 4 1}$ & 1,44 & 0,22 & 0,00 & 10,08 & 3,46 & 13,54 & 86,46 & 100 \\
T-V2 & R1 & 3,42 & 1,96 & 0,11 & 0,00 & 5,49 & 0,00 & 5,49 & 94,51 & 100 \\
& R2 & 6,31 & 0,57 & 0,19 & 0,00 & 7,07 & 0,00 & 7,07 & 92,93 & 100 \\
& R3 & 6,32 & 1,15 & 0,30 & 0,00 & 7,77 & 0,00 & 7,77 & 92,23 & 100 \\
& R4 & 6,06 & 0,69 & 0,23 & 0,00 & 6,98 & 0,00 & 6,98 & 93,02 & 100 \\
T-V3 & R1 & 4,07 & 0,76 & 0,41 & 0,00 & 5,23 & 0,00 & 5,23 & 94,77 & 100 \\
& R2 & 4,08 & 1,95 & 1,51 & 0,00 & 7,54 & 0,00 & 7,54 & 92,46 & 100 \\
& R3 & 2,41 & 0,18 & 0,24 & 0,00 & 2,83 & 0,00 & 2,83 & 97,17 & 100 \\
& R4 & 4,23 & 0,71 & 0,11 & 0,00 & 5,05 & 0,00 & 5,05 & 94,95 & 100 \\
T-V4 & R1 & 4,26 & 1,55 & 1,01 & 0,00 & 6,81 & 0,00 & 6,81 & 93,19 & 100 \\
& R2 & 4,79 & 0,00 & 0,80 & 2,19 & 7,78 & 0,00 & 7,78 & 92,22 & 100 \\
& R3 & 8,15 & 2,14 & 0,87 & 0,00 & 11,15 & 0,00 & 11,15 & 88,85 & 100 \\
& R4 & 3,28 & 1,30 & 1,04 & 0,00 & 5,61 & 0,00 & 5,61 & 94,39 & 100 \\
\hline
\end{tabular}


Quadro 22. Valores das amostras para análise tecnológica da matéria prima.

\begin{tabular}{ccccccccc}
\hline \multirow{2}{*}{ Trat. } & Rep. & \multicolumn{7}{c}{ \% do Caldo extraído } \\
& Peso & Brix & Pol & Pureza & Fibra & Pol & Kg.terra $^{-1}$ \\
\hline T-V1 & R1 & 71,02 & 16,9 & 13,57 & 80,3 & 13,66 & 11,16 & 0,5 \\
& R2 & 73,24 & 16 & 13,45 & 82,54 & 11,97 & 11,4 & 1,3 \\
& R3 & 71,98 & 18 & 14,87 & 82,62 & 13,93 & 12,39 & 0,9 \\
& R4 & 71,9 & 18,2 & 15 & 83,44 & 13,99 & 12,99 & 0,1 \\
\hline T-V2 & R1 & 72,82 & 16,4 & 13,93 & 84,97 & 12,29 & 11,74 & 4,6 \\
& R2 & 73,52 & 16,8 & 13,83 & 82,33 & 11,76 & 11,76 & 1,3 \\
& R3 & 72,44 & 17,5 & 14,46 & 82,61 & 12,58 & 12,12 & 1,6 \\
& R4 & 71,94 & 17,4 & 14,75 & 84,78 & 12,96 & 12,29 & 0,1 \\
\hline T-V3 & R1 & 71,1 & 17,2 & 14,68 & 85,35 & 13,6 & 12,09 & 2,7 \\
& R2 & 71,38 & 17,3 & 14,48 & 83,67 & 13,38 & 11,97 & 4,2 \\
& R3 & 72,06 & 16,7 & 13,69 & 81,95 & 12,87 & 11,42 & 0,2 \\
& R4 & 73,72 & 17,3 & 14,76 & 85,3 & 11,61 & 12,58 & 0,2 \\
\hline T-V4 & R1 & 72,22 & 16 & 12,83 & 80,21 & 12,75 & 10,73 & 2,4 \\
& R2 & 69,78 & 17,1 & 14,17 & 82,84 & 14,6 & 11,46 & 7,1 \\
& R3 & 72,78 & 17,8 & 15,06 & 84,62 & 12,32 & 12,68 & 2 \\
& R4 & 73,22 & 15,3 & 12,4 & 81,06 & 11,99 & 10,5 & 0,9 \\
\hline
\end{tabular}

